UNIVERSIDADE DE BRASÍLIA

CENTRO DE DESENVOLVIMENTO SUSTENTÁVEL - CDS

\title{
APLICAÇÃO DA MODERNIZAÇÃO ECOLÓGICA NO SETOR DE PAPEL E CELULOSE DO BRASIL
}

\author{
Antônio José Juliani
}

Orientador: Prof. Dr. Armando Caldeira-Pires

Tese de Doutorado

Brasília - DF, setembro de 2015. 


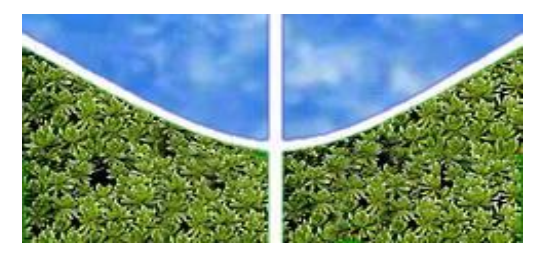

UNIVERSIDADE DE BRASÍLIA

CENTRO DE DESENVOLVIMENTO SUSTENTÁVEL

\title{
APLICAÇÃO DA MODERNIZAÇÃO ECOLÓGICA NO SETOR DE PAPEL E CELULOSE DO BRASIL
}

\author{
Antônio José Juliani
}

Tese de Doutorado submetida ao Centro de Desenvolvimento Sustentável da Universidade de Brasília, como parte dos requisitos necessários para a obtenção do Grau de Doutor em Desenvolvimento Sustentável, área de concentração em Política e Gestão Ambiental, opção acadêmica.

Aprovado por:

Prof. Armando Caldeira- Pires, (UNB), Doutor.

Orientador

Prof $^{a}$. Doris Aleida Villamizar Sayago, (UNB), Doutora.

Examinadora Interna

Prof. Thomas Ludewigs, (UNB), Doutor.

Examinador Interno

Prof. Bruno Milanez, (UFJF), Doutor.

Examinador Externo

Prof. Gustavo Ferreira Ribeiro, (UNICEUB), Doutor.

Examinador Externo

Brasília - DF, setembro de 2015. 
Dedico essa tese para meu pai José Juliani, minha mãe Rita Terassi Juliani e meu irmão Bráz Fernando Juliani (in memoriam), pelo amor, pelo carinho e pelo respeito incondicionais compartilhados durante o tempo que nos foi permitido dividir. 


\section{AGRADECIMENTOS}

O período de elaboração de uma tese é muito difícil e ao mesmo tempo muito prazeroso. Difícil porque lidamos com as muitas inquietações geradas pela pesquisa. Questões referentes aos encaminhamentos possíveis da tese, à consecução da metodologia, à obtenção e tratamento dos dados, enfim, vários percalços que se retroalimentam durante todo o processo de elaboração da mesma. Isso se torna difícil não somente para o doutorando, mas também para as pessoas que o cercam. A família, os amigos, os vizinhos, o orientador, o terapeuta, os colegas de trabalho, os animais de estimação, enfim, aqueles que estão a sua volta e que não se cansam de, pelo menos, escutá-lo, e , quando podem, contribuírem para que o final seja feliz.

Porém, é um período também prazeroso já que o pesquisador escolheu um tema que Ihe atrai que acredita ser relevante para ele, para a sociedade, para a academia e para o país, a ponto de dedicar muito tempo e pesquisar incansavelmente sobre o tema. Desvendar o problema proposto é um processo que the acalma as inquietações e lhe traz o prazer de avançar na discussão, mesmo sabendo que esta não terá fim.

A caracterização desse período se torna necessária para identificar as dificuldades e as alegrias vividas durante a elaboração da tese. Isso esclarece um pouco a importância que várias pessoas tiveram durante o processo. Mesmo com receio de esquecer alguém, pois são muitas as pessoas que me ajudaram, gostaria de agradecer a todos que direta ou indiretamente me apoiaram nesse período importante de minha vida.

Primeiramente, gostaria de expressar minha fé e agradecer Nossa Senhora Aparecida, pela luz protetora que me fortalece espiritualmente nos momentos mais difíceis de minha vida. Agradeço também a todos que me apoiaram no processo de formação acadêmica. Inicialmente, agradeço aos professores da Universidade Federal de São Carlos (UFSCAR), que me apoiaram e incentivaram desde minha entrada na universidade e permitiram que eu conhecesse e usufruísse das oportunidades que a educação de qualidade oferece no Brasil.

Agradeço também a Universidade de Brasília (UNB), especificamente, o Instituto de Relações Internacionais (IREL) e o Centro de Desenvolvimento Sustentável (CDS) pela oportunidade que me foi oferecida para cursar os programas de pós-graduação (especialização, mestrado e doutorado). Sem essas oportunidades que me foram abertas, as conquistas realizadas não passariam de meros sonhos. A conquista do título de doutor foi uma realidade viabilizada somente pela abertura destas oportunidades. $\mathrm{Na}$ verdade agradeço às pessoas que fazem parte destas instituições, desde o corpo diretivo, ao corpo administrativo e aos colegas, muitos dos quais são grandes amigos. Não cito nomes por 
acreditar que todos têm alguma parcela de participação em tudo isso. A todos quero registrar minha gratidão.

Agradeço ao meu orientador, Prof. Armando Caldeira-Pires, que aceitou o desafio de desenvolvermos essa pesquisa, me apoiou, orientou e, acima de tudo, expressou sua amizade demonstrando confiaça em meu trabalho. Agradeço a todos os professores do CDS por reforçarem a idéia de que, juntamente com a evolução da ciência em todas as suas dimensões, o conhecimento também deve proporcionar o aprimoramento integral do ser humano, motivando-o a ser ético e fazer da ciência um instrumento para a busca do bem coletivo.

Agradeço aos membros da banca pela atenção recebida e pelo privilégio de poder tê-los na minha defesa de tese. Agradeço ainda a todos os meus colegas da turma de doutorado de 2011, pelos momentos felizes de plena aprendizagem e pela troca de experiências tão singulares de vida. Meus agradecimentos também ao Programa das Nações Unidas para o Meio Ambiente (PNUMA) e ao Ministério do Desenvolvimento, Indústria e Comércio Exterior (MDIC), sem os quais, essa pesquisa não teria sido realizada.

Expresso minha gratidão à Associação Brasileira de Celulose e Papel (BRACELPA), à Associação Brasileira Técnica de Celulose e Papel (ABTCP) e aos representantes do grupo International Paper do Brasil Ltda (IP), especialmente, aos funcionários da fábrica de Luiz Antônio, na pessoa do Sr.Wanderlei Peron, que foi fundamental para que o Projeto de Cooperação MDIC/PNUMA/União Européia, fosse bem sucedido. Agradeço ainda os Professores Celso Foelckel e André Fábio de Souza por compartilharem comigo o amplo conhecimento adquirido na vida acadêmica e nos anos incansáveis de dedicação para a educação.

Por fim, agradeço a família dos meus vizinhos, nas pessoas do Sr. Pedro e Sra. Fátima, que substituíram a minha própria família e estiveram do meu lado durante todo o processo de elaboração desta tese, me apoiando, me ouvindo, me dando força, me animando e me oferecendo as condições necessárias para que o meu sonho se tornasse uma realidade. Obrigado de coração, a todos. 


\section{RESUMO}

Este trabalho teve como objetivo a aplicação da Modernização Ecológica (ME) no setor de papel e celulose do Brasil. A origem da ME foi na década de 1980, na Alemanha, e envolve diversas áreas de conhecimento como Sociologia, Ciência Política, Engenharia e Economia. Para a consecução desta tese a ME foi entendida como campo teórico que tem por base quatro pressupostos: confiança no desenvolvimento científico e tecnológico; preferência por soluções preventivas para os problemas ambientais; possibilidade de se alcançar simultaneamente objetivos ambientais e econômicos; e envolvimento direto e cooperativo na tomada de decisão. Considerou-se a rotulagem ambiental como instrumento de aplicação dessa teoria. Nesta pesquisa, a partir de um estudo de caso do setor de papel e celulose do Brasil, foram avaliadas, dentre outras características, a capacidade de a rotulagem ambiental: a) alterar níveis de padrões de produção vigentes para níveis considerados mais sustentáveis; b) incentivar a inovação ambiental e; c) aumentar a competitividade de produtos nacionais em mercados globais. O referido estudo foi dividido em três partes. Na primeira parte foram apresentados os conceitos-chave que sustentam o arcabouço teórico da ME, especialmente, as suas abordagens originais, suas características e princípios básicos e, alguns caminhos conceituais trilhados por essa perspectiva teórica com o intuito de oferecer explicação mais detalhada do conjunto de temas que constituem a base de uma de suas hipóteses norteadoras: a emancipação da ecologia e a ecologização da economia como dois processos simultâneos. Na segunda parte discorreu-se sobre a rotulagem ambiental, seus conceitos básicos, tipos, principais objetivos e princípios norteadores e sua relação com a ME. Por fim, foi apresentado o estudo de caso referente à fábrica de Luiz Antônio do grupo International Paper do Brasil Ltda, empresa que pertence ao setor de papel e celulose nacional e que obteve o rótulo ambiental da União Européia, denominado Flower, para o papel de imprimir e escrever, com o objetivo de aumentar a competitividade do referido produto em mercados globais e melhorar o desempenho ambiental de seu processo produtivo. As conclusões desta pesquisa apontam que a rotulagem ambiental: a) é instrumento efetivo de aplicação da ME; b) incentiva a criação de inovações ambientais; c) aumenta a competitividade dos produtos nacionais em mercados mais exigentes com as questões ambientais e d) contribui para mudanças nos padrões de produção das indústrias.

Palavras-chave: modernização ecológica; padrões de produção; rotulagem ambiental; inovação ambiental; international paper do Brasil. 


\begin{abstract}
This study aimed at the implementation of Ecological Modernization (EM) in the paper and pulp sector in Brazil. The origin of EM dating from the early 1980s in Germany, and involves several areas of knowledge such as sociology, political science, engineering and economics. To achieve this thesis, EM was understood as a theoretical field which is based on four assumptions: confidence in scientific and technological development; preference for preventive solutions to environmental problems; ability to simultaneously achieve environmental and economic goals; and direct involvement and cooperative decision-making. Ecolabelling was considered as a tool for application of this theory. In this research, from a case study of the paper and pulp sector in Brazil, we were evaluated, among other features, the ability of ecolabelling: a) change current levels of production patterns to levels considered more sustainable; b) encourage environmental innovation and; c) increase the competitiveness of national products in global markets. The study was divided into three parts. In the first part were presented the key concepts underpinning the theoretical framework of EM especially their original approaches, their characteristics and principles and some conceptual paths taken by this theoretical perspective in order to provide more detailed explanation of the set of themes that form the basis of one of its guiding assumptions: the emancipation of ecology and the greening of the economy as two simultaneous processes. In the second part we spoke up on ecolabelling, its basic concepts, types, main objectives and guiding principles and its relationship with EM. Finally, we have presented the case study of the factory Luiz Antônio- International Paper Group of Brazil, a company that belongs to the pulp and paper domestic industry and that obtained the ecolabel of the European Union, called Flower, for the printing and writing paper, in order to increase the competitiveness of the product in global markets and improve the environmental performance of its production process. The findings of this research suggest that the ecolabelling: a) is an effective tool for the application of EM; b) encourages the creation of environmental innovations; c) increases the competitiveness of national products in the most demanding markets with environmental issues and; d) contributes to changes in the industrial production patterns.
\end{abstract}

Keywords: ecological modernization; production patterns; ecolabelling; environmental innovation; international paper of Brazil. 


\section{RÉSUMÉ}

Cette étude a visé l'application de la Modernisation Écologique (ME) dans le secteur des pâtes et papiers au Brésil. L'origine de la ME a été dans les années 1980, en Allemagne, et implique plusieurs domaines de la connaissance telles que la sociologie, la science politique, l'ingénierie et l'économie. Pour la concrétisation de cette thèse, la ME a été comprise comme un champ théorique qui est basé sur quatre hypothèses: la confiance dans le développement scientifique et technologique; la préférence pour les solutions préventives aux problèmes environnementaux; la possibilité d'atteindre simultanément des objectifs environnementaux et économiques; et l'engagement direct coopératif dans la prise de décision. L'étiquetage environnemental a été consideré comme un instrument pour la mise en application de cette théorie. Dans cette recherche, à partir d'une étude de cas sur le secteur des pâtes et papiers au Brésil, on a évalué, entre d'autres caractéristiques, la capacité de l'étiquetage environnemental de: a) modifier des niveaux des standards de production actuels à des niveaux considérés plus soutenables; b) encourager l'innovation environnementale; c) accroître la compétitivité des produits nationaux sur les marchés mondiaux. L'étude suivante a été divisée en trois parties. Dans la première partie, les concepts clés sous-tendant le cadre théorique de la ME ont été présentés, particulièrement leurs approches originales, leurs caractéristiques et principes et certaines voies conceptuelles prises par cette perspective théorique afin de fournir des explications plus détaillées sur l'ensemble des thèmes qui forment la base de l'un de ses hypothèses directrices: l'émancipation de l'écologie et de l'économie verte comme deux processus simultanés. Dans la deuxième partie, nous avons présenté l'étiquetage environnemental, ses concepts de base, les types, les principaux objectifs et les principes directeurs et de sa relation avec la ME. Enfin, nous avons présenté l'étude de cas concernant à la fabrique de Luiz Antônio du groupe International Paper do Brasil Ltda, une entreprise qui appartient à l'industrie de la pâte et du papier domestique et qui a obtenu l'étiquette écologique de l'Union Européenne, appelée Flower, pour le papier d'imprimer et d'écrire, afin d'accroître la compétitivité du produit sur les marchés mondiaux et d'améliorer la performance environnementale de son processus de production. Les résultats de cette recherche suggèrent que l'étiquetage environnemental: a) est un instrument efficace pour la mise en application de la ME; b) encourage la création d'innovations environnementales; c) augmente la compétitivité des produits nationaux sur les marchés les plus exigeants avec des enjeux environnementaux d) contribue pour changer les standards de la production industrielle.

Mots-clés: modernisation écologique; standards de production; étiquetage environnemental; innovation environnementale; International paper do Brasil. 


\section{LISTA DE ILUSTRAÇÕES}

Figura 1 - Mecanismos do processo de Marrakesh. .74

Figura 2 - Rótulo ambiental da União Européia. .125

Figura 3 - Rótulo ambiental da ABNT .136

Figura 4 - O processo Kraft de fabricação da celulose e a recuperação de produtos químicos em uma planta integrada 160

Figura 5 - Etapas básicas para a fabricação de papel 162

Figura 6- Vista aérea da fábrica de Luiz Antônio (SP), do Grupo International Paper (I P). 164

Figura 7- Preparação da madeira. .165

Figura 8 - Armazenagem das aparas e a disposição em pilhas. 166

Figura 9 - Digestor da fábrica de Luiz Antônio 167

Figura 10 - Processo de remoção dos nós, lavagem, deslignificação com oxigênio e depuração da massa.

Figura 11 - A Torre de branqueamento .168

Figura 12- Máquinas de papel. 169

Figura 13 - Algumas fases do setor de acabamento 170

Figura 14 - Caldeira auxiliar e turbogerador

Figura 15 - Recuperação da caldeira.

Figura 16 - Área de caustificação 188

Figura 17 - Produção de dióxido de cloro. . .189

Figura 18 - Produção de compostagem. 


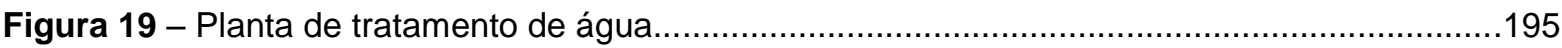

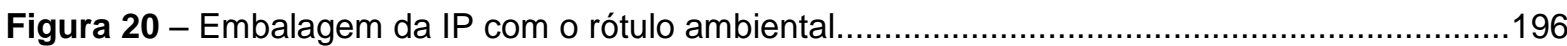




\section{LISTA DE QUADROS}

Quadro 1.1 - Exemplos de problemas ambientais da política de controle da poluição .14

Quadro 2.1 - A Nova estrutura dupla do Estado: hierarquia e cooperação.

Quadro 2.2 - Natureza da Inovação Industrial

Quadro 3.1 - Classificação dos tipos de rotulagem ambiental.

Quadro 3.2- Comparação dos três tipos de rótulos e declarações

Quadro 3.3 - Programas de rotulagem ambiental tipo I no mundo

Quadro 3.4 - Normas ISO de gestão e auditorias ambientais

Quadro 3.5 - Normas ISO de rotulagem e avaliação de desempenho ambiental

Quadro 3.6 - Normas ISO de avaliação do ciclo de vida, termos usados em gestão ambiental e aspectos ambientais para produtos

Quadro 3.7 - Princípios orientadores para rotulagem ambiental - rótulo tipo I - ISO 14020 .116

Quadro 3.8 - Princípios orientadores para programas de rotulagem ambiental - ISO 14024

Quadro 3.9 - Grupo de produtos com critérios estabelecidos para a obtenção do Flower.

Quadro 3.10- Preços cobrados para a obtenção do Flower. .129

Quadro 4.1 - Países participantes, produtos escolhidos e coordenadores nacionais

Quadro 4.2 - Valores de referência para emissões da produção de diferentes tipos de celulose e papel.

Quadro 4.3- Emissões de COD, Enxofre (S) e Óxidos de Nitrogênio ( NOX) em Kg/ADT, em 2009.

Quadro 4.4- Emissões de COD, Enxofre (S) e Óxidos de Nitrogênio ( NOX) em Kg/ADT, em 2009. 
Quadro 4.5 - Valores para as emissões em termos de pontos .173

Quadro 4.6 - Emissões de compostos orgânicos halogenados AOX em Kg/ADT, em 2009. 173

Quadro 4.7 - Valores de referência para serem usados no cálculo das emissões de $\mathrm{CO}_{2}$ .174

Quadro 4.8 - Valores referentes às emissões de $\mathrm{CO}_{2}$ em 2009. 174

Quadro 4.9 - Valores de referência para a eletricidade e o combustível..... 175

Quadro 4.10- Consumo de energia em KWh/ADT em 2009 .177

Quadro 4.11 - Consumo de combustível para produção de energia térmica KWh/ADT em 2009...177

Quadro 4.12 - Valores para $P_{E}$ e $P_{F}$. 178

Quadro 4.13 - Planejamento da produção florestal da International Paper do Brasil. 179

Quadro 4.14 - Alguns indicadores de consumo de recursos e de reciclagem em 2009. 182

Quadro 4.15- Informações sobre o tipo de fibra utilizada pela fábrica de Luiz Antôniol. 182

Quadro 4.16- Aminas aromáticas proibidas. 184

Quadro 4.17 - Origem e destino dos resíduos gerados na fábrica de Luiz Antonio. 193

Quadro 4.18 - Geração média anual de resíduos sólidos. 194

Quadro 4.19- Volumes médios esperados nas águas residuais 194

Quadro 4.20 - Critérios avaliados e resultados apresentados pela fábrica de Luiz Antônio. 198

Quadro 4.21 - Produção de papel para imprimir e escrever das fábricas do grupo IP e do grupo Suzano Papel e Celulose (mil toneladas). 201

Quadro 4.22 - Produção Brasileira de papel para imprimir e escrever 201

Quadro 4.23 - Consumo de energia das fábricas do grupo IP (GJ) 202

Quadro 4.24 - Consumo de energia das fábricas do grupo IP (GJ/t papel) 202 
Quadro 4.25- Intensidade energética (KWh/t) 204

Quadro 4.26 - Iniciativas da IP para redução no consumo de energia. .204

Quadro 4.27 - Consumo de energia das fábricas do grupo Suzano (GJ)...... 205

Quadro 4.28 - Consumo de energia das fábricas do grupo Suzano (GJ/t papel). .206

Quadro 4.29 - Volume total de água retirada, reciclada e reutilizada ( $\left.\mathrm{m}^{3} / \mathrm{ano}\right)$ 207

Quadro 4.30- Volume total de água captada por tonelada de papel produzido $\left(\mathrm{m}^{3} / \mathrm{ano}\right.$ .208

Quadro 4.31 - Emissões diretas e indiretas de gases de efeito estufa (ton $\mathrm{CO}_{2 \text { eq }}$ ) 209

Quadro 4.32 - Emissões de gases de efeito estufa por tonelada de papel produzido 211

Quadro 4.33 - Emissões de NOX, SOX e outros gases (toneladas). 212

Quadro 4.34 - Emissões de NOX, SOX e outros gases por tonelada de papel. .212

Quadro 4.35 - Emissões de NOX, SOX e outros gases. 213

Quadro 4.36 - Descartes de DQO, DBO e descartes totais por tonelada de papel produzido. 214

Quadro 4.37 - Descartes de DQO, DBO e descartes totais por tonelada de papel produzido. 215

Quadro 4.38 - Produção de Papel (1.000 toneladas).... 216

Quadro 4.39 - Vendas Domésticas de papel (1.000 toneladas). 217

Quadro 4.40 - Exportações de papel (1.000 toneladas). 217

Quadro 4.41 - Exportações brasileiras de papel por destino (US\$ - FOB)...... 218

Quadro 4.42 - Cálculo do Resultado econômico das exportações de papel para imprimir e escrever da fábrica de Luiz Antônio - SP 


\section{LISTA DE ABREVIATURAS E SIGLAS}

AAO - Associação de Agricultura Orgânica

ABNT - Associação Brasileira de Normas Técnicas

ABTCP - Associação Brasileira Técnica de Celulose e Papel

ACV - Avaliação do Ciclo de Vida

BRACELPA - Associação Brasileira de Celulose e Papel

CDS - Centro de Desenvolvimento Sustentável

CEPAL - Comissão Econômica para a América Latina

CERFLOR - Certificação Florestal

CETCEP - Centro de Tecnologia em Celulose e Papel

CNUMAD - Conferência das Nações Unidas para Meio Ambiente e Desenvolvimento

CSIR - Council for Scientific and Industrial Research

CTE - Comission on Trade and Environment

CUTS - Consumer Unity \& Trust Society

EPC - Environment Protection Centre

ENGOs - Organizações Não Governamentais de Meio Ambiente

EPA - Environemntal Protection Agency

EPIS - Environmental Products Information Systems

FAO - Food and Agricultural Organization

FSC - Forest Stewardship Council

GEN - Global Ecolabelling Network

IBD - Instituto Biodinâmico

IDEC - Instituto Brasileiro de Defesa do Consumidor

IMNC - Instituto Mexicano de Normalización y Certificación

IP - International Paper

ISO - International Organization for Standardization

IUCN - International Union for Conservation of Nature

KNCPC - Kenian National Cleaner Production Centre

LEED - Leadership in Energy and Environmental Design

MCTI - Ministério da Ciência, Tecnologia e Inovação.

MDIC - Ministério do Desenvolvimento, Indústria e Comércio Exterior.

ME - Ministério de Energia

METI - Ministry of Economy, Trade and Industry

MIT - Massachusetts Institute of Technology

MMA - Ministério do Meio Ambiente

MRE- Ministério das Relações Exteriores

NEPA - National Environmental Policy Act

OCDE - Organização para Cooperação e Desenvolvimento Econômico 
OMC - Organização Mundial do Comércio

PEFC - Programme for the Endorsement of Forest Certification

PIB - Produto Interno Bruto

PNUMA- Programa das Nações Unidas para o Meio Ambiente

UFRJ - Universidade Federal do Rio de Janeiro

UNB - Universidade de Brasília

UNDESA- United Nations Departament of Economic and Social Affairs

UNECE - United Nations Economic Comission for Europe

UNESCO - The United Nations Educational, Scientific \& Cultural Organization

USP - Universidade de São Paulo

WCED - World Commission on Environment and Development

WCS - World Conservation Strategy

WRI - World Resources Institute

WWF- World Wildlife Fund 


\section{SUMÁRIO}

INTRODUÇÃO GERAL..............................................................................................1

Capítulo1. ANTECEDENTES DA MODERNIZAÇÃO ECOLÓGICA.............................. 10

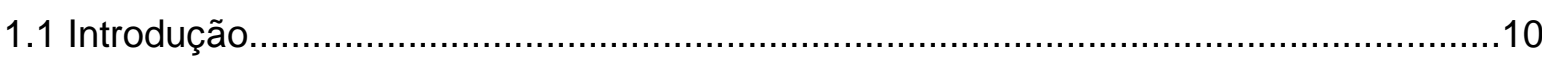

1.2. A resposta política para as questões ambientais na década de $1970 \ldots \ldots \ldots \ldots \ldots \ldots \ldots . . . . . . . . . .12$

1.3 Os novos tipos de poluição e os primeiros esboços da nova política......................... 21

1.4 Os primeiros posicionamentos para a mudança........................................................ 28

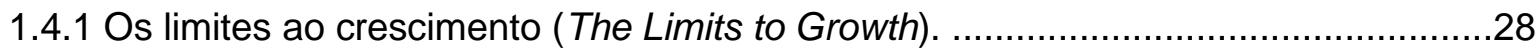

1.4.2 Um modelo para a sobrevivência (Blueprint for Survival)........................................ 31

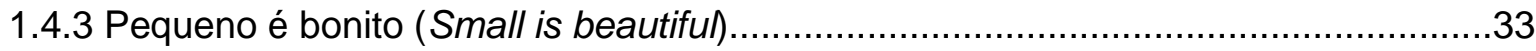

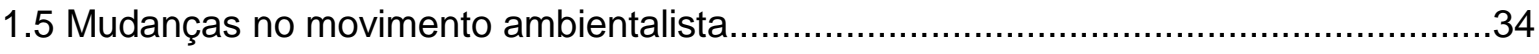

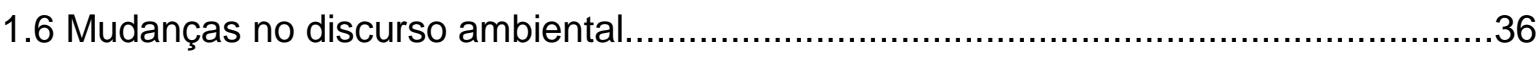

Capítulo 2. A EMERGÊNCIA DA MODERNIZAÇÃO ECOLÓGICA...............................41

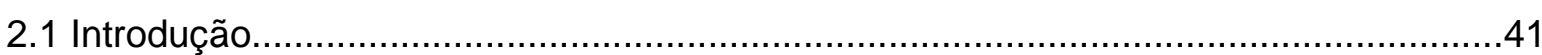

2.2 Apresentação das características e dos pressupostos básicos da ME........................41

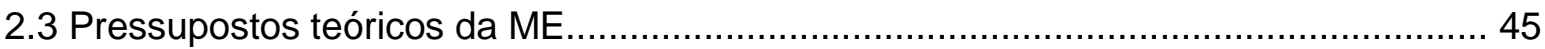

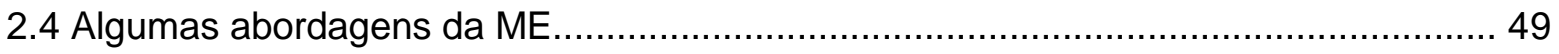

2.4.1 A ME como modernização política..................................................................... 49

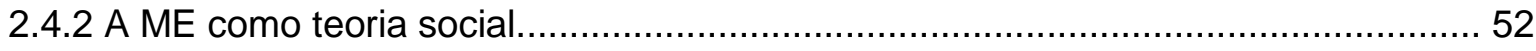

2.4.3 A ME como modernização da modernidade..................................................... 54

2.4.4 A ME como inovação tecnológica ambiental.........................................................57

2.5 As oportunidades para o melhoramento ambiental na indústria................................. 62

2.6 Considerações sobre as inovações no consumo e na produção como preocupações

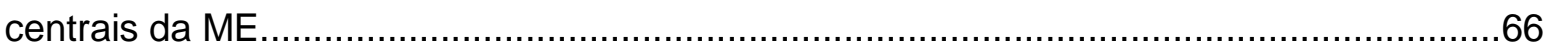

2.6.1 Orientação à montante de debates de tecnologia ambiental..................................6 66

2.6.2 Mudança do foco da produção para o consumo.....................................................73

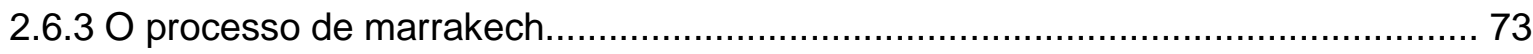

2.6.4 A necessidade de modernização da ME...............................................................

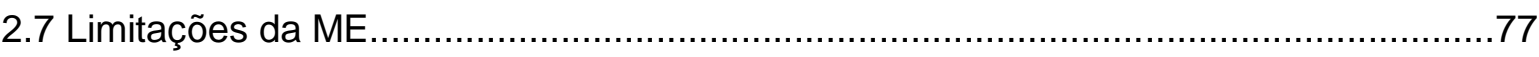

Capítulo 3. A MODERNIZAÇÃO ECOLÓGICA E A ROTULAGEM AMBIENTAL..............80

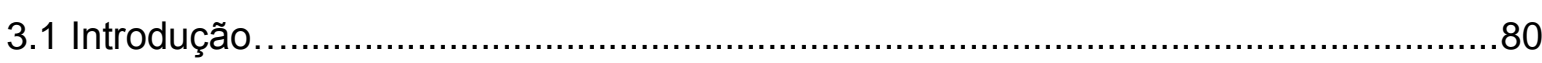

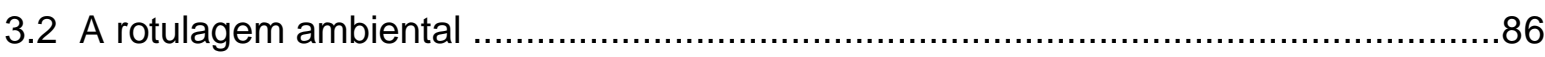

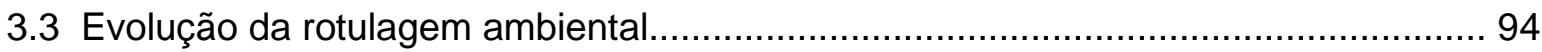

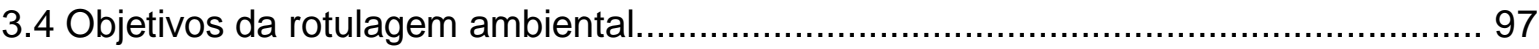

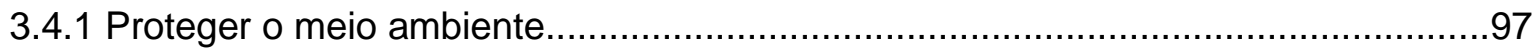

3.4.2 Incentivar a inovação e a liderança ambientalmente sustentável...........................98 
3.4.3 Conscientizar o consumidor sobre as questões ambientais.................................98

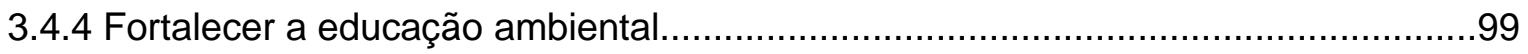

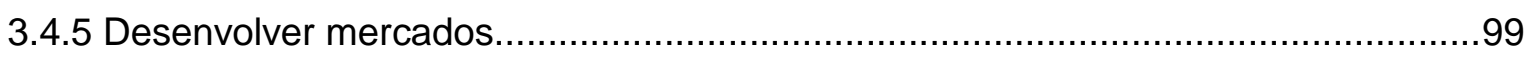

3.4.6 Fortalecer políticas públicas ambientais......................................................100

3.5 Fundamentos teóricos da rotulagem ambiental.................................................... 100

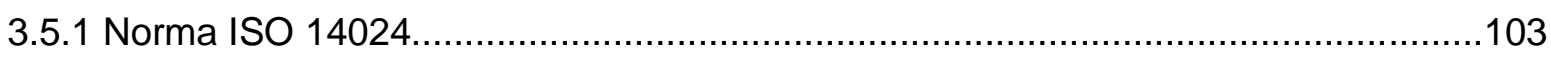

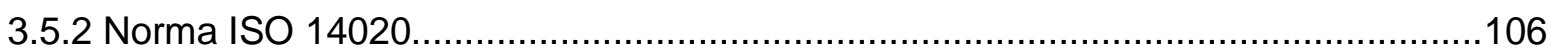

3.5.3 Análise do ciclo de vida do produto (ACV) .......................................................107

3.5.4 Ferramentas de avaliação da conformidade........................................................109

3.5.5 Boas práticas da normalização..........................................................................109

3.6 Programas de rotulagem ambiental............................................................. 110

3.6.1 Princípios orientadores de programas de rotulagem ambiental.............................112

3.6.1.1 A participação voluntária...........................................................................113

3.6.1.2 Cumprimento da legislação ambiental e de outras legislações pertinentes........113

3.6.1.3 Apreciação de adequação à finalidade e nível de desempenho geral...............113

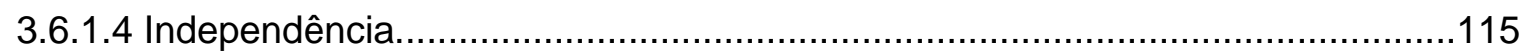

3.6.1.5 Coerência com a ISO 14020 e ISO 14024, princípios orientadores ou outras

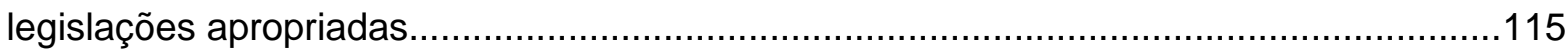

3.6.2 Principais parceiros dos programas de rotulagem ambiental..............................117

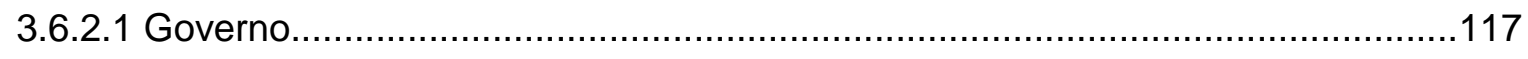

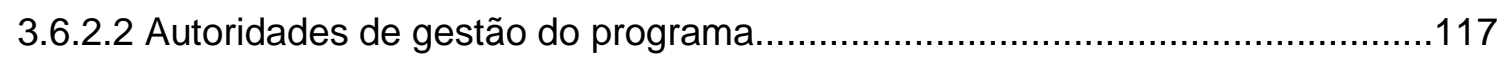

3.6.2.3 Indústria e associações comerciais..........................................................117

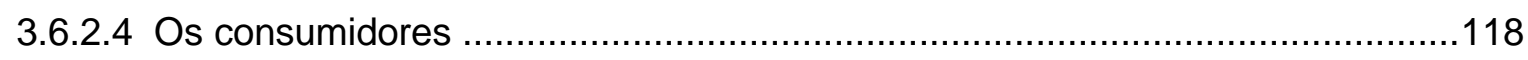

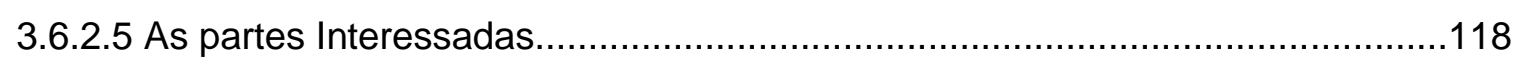

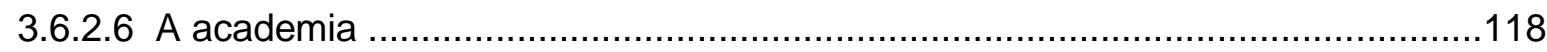

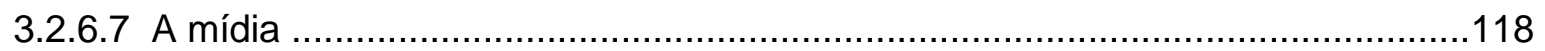

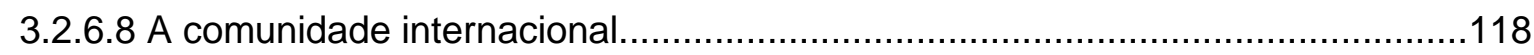

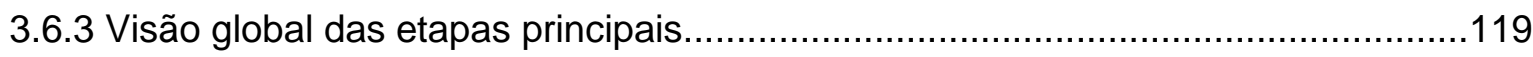

3.6.3.1 Seleção e determinação de categorias de produtos.......................................119

3.6.3.2 Desenvolvimento e adoção de critérios, normas ou diretrizes apropriadas........119

3.6.3.3 A certificação e o licenciamento.................................................................... 121

3.6.4 Mensuração d a eficácia do programa de rotulagem ambiental.............................121

3.6.4.1 A Melhoria da qualidade ambiental dos produtos certificados...........................122

3.6.4.2 A Demanda e o reconhecimento do consumidor............................................123

3.7 Considerações sobre o programa de rotulagem ambiental da União Européia..........124

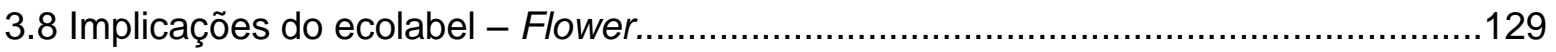

3.9 A rotulagem ambiental no Brasil..................................................................... 135 
3.9.1 O Programa de qualidade ambiental da ABNT. 136

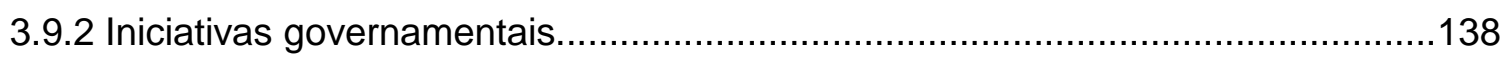

3.9.3 A certificação florestal no Brasil............................................................. 140

3.10 limitações no uso de programas de rotulagem ambiental....................................141

Capítulo 4. ESTUDO DE CASO SOBRE O PROCESSO DE OBTENÇÃO DO FLOWER PELA FÁBRICA DE LUIZ ANTÔNIO NO BRASIL......................................................147

4.1 Introdução 147

4.2 Do projeto de cooperação entre o MDIC/SECEX, a União Européia e o Programa das Nações Unidas para o Meio Ambiente (PNUMA). 149

4.3 Considerações sobre o setor de papel e celulose do Brasil....................................... 153

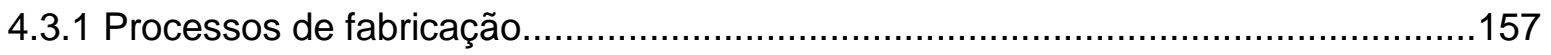

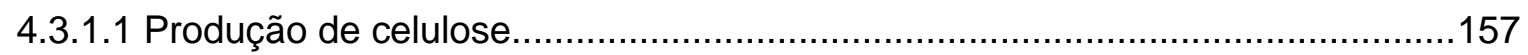

4.3.1.1.1 Processos químicos e semiquïmicos para a produção de celulose e o processo kraft 158

4.3.1.2 Produção de papel. 161

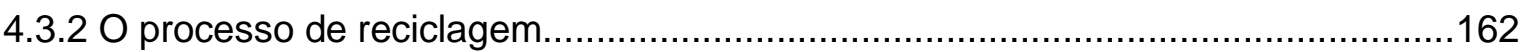

4.4 O Grupo International Paper do Brasil Ltda ..................................................... 163

4.4.1 Descrição do processo de produção da International Paper do Brasil Ltda...........164

4.4.1.1 Processo de Produção da celulose.................................................................165

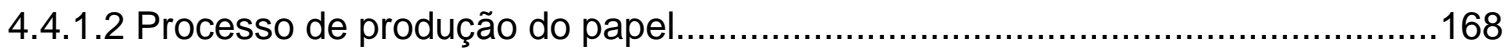

4.5 Considerações sobre os critérios exigidos para a obtenção do Flower e apresentação dos resultados obtidos pela fábrica de Luiz Antônio. 170

4.5.1 Critérios considerados para o processo de avaliação da fábrica de Luiz Antônio.... 171

4.5.1.1 Emissões para a àgua e para a atmosfera... 171

4.5.1.1.1 Demanda química de carbono dissolvido (CDO), enxofre (S) e oxidos de nitrogênio $\left(\mathrm{NO}_{\mathrm{x}}\right)$. 171

4.5.1.1.2 Demanda química de compostos halogenados $\left(\mathrm{AO}_{\mathrm{x}}\right)$ 173

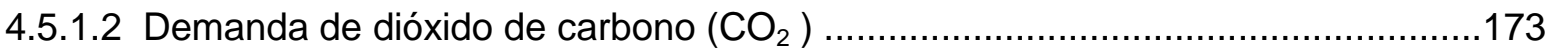

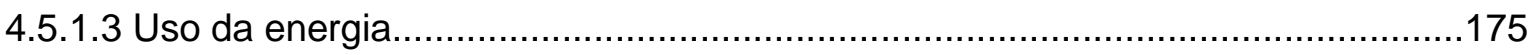

4.5.1.4 Fibras - gestão sustentável das florestas....................................................178

4.5.1.5 Manejo de substâncias químicas perigosas....................................................... 182

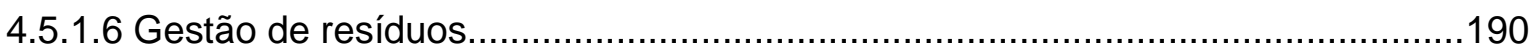

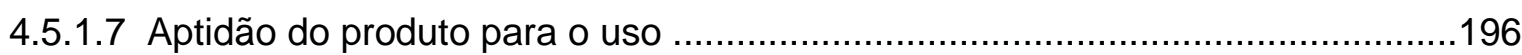

4.51.8 Informações que devem constar na embalagem do produto...............................196

4.5.1.9 Informações que devem constar no rótulo ambiental..........................................197

4.6 Análise dos dados obtidos no processo de rotulagem...........................................197 
4.7 Análise e comparação do desempenho ambiental da fábrica de Luiz Antônio com outras fábricas do setor de papel e celulose ......................................................................200

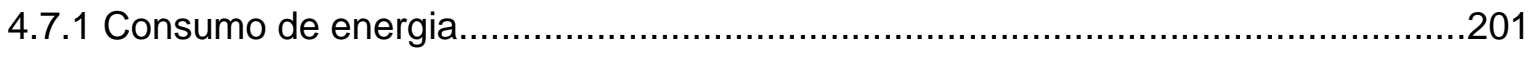

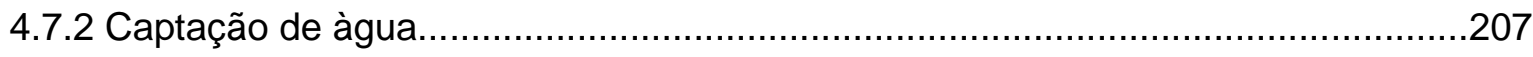

4.7.3 Emissões de gases de efeito estufa e outros gases..........................................209

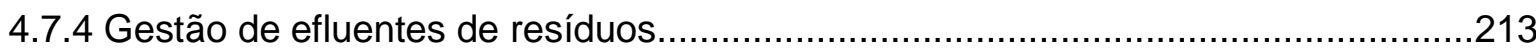

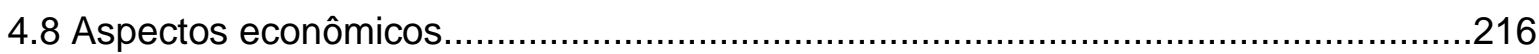

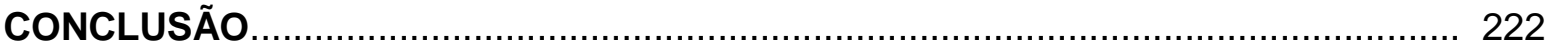

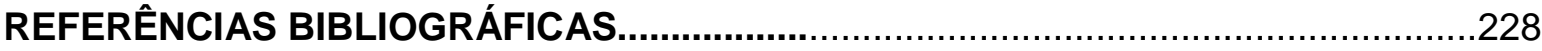




\section{INTRODUÇÃO GERAL}

Nas últimas três décadas do século $X X$, ambientalistas, economistas e cientistas políticos e sociais registraram mudanças significativas no nível de conscientização da sociedade global referente à compreensão das questões relacionadas com 0 meio ambiente.

Agências estatais, setores ligados ao mundo dos negócios, associações de interesses, representantes da sociedade civil e de organizações não governamentais (ONGs) tanto no âmbito nacional quanto no internacional e a academia, definiram a crise ambiental com a consideração de perspectivas específicas.

A crise ambiental foi definida como um dos principais desafios para o alcance de um novo redirecionamento do desenvolvimento rumo à sustentabilidade notadamente, das dimensões econômicas, política, social, ambiental e cultural.

O futuro do planeta depende da capacidade de a humanidade proporcionar qualidade de vida para uma população que pode atingir em 2030 , um total de nove bilhões de pessoas, sem, no entanto, esgotar os recursos naturais ou alterar de forma irreversível seus sistemas bioquímicos (TUKKER et al, 2010).

Sabe-se que as populações dos países desenvolvidos representam $20 \%$ da população mundial e são responsáveis por $80 \%$ do consumo global. O desafio desses países é fazer mais com menos, reduzir suas pegadas ecológicas e o excesso de consumo de recursos (SCHOR, 2005).

Por outro lado, os diferentes países enfrentam desafios diferentes. As sociedades estão passando por modificações significativas, principalmente, relacionadas com o aprimoramento da infraestrutura. Fato que representa uma oportunidade única para que se encontrem alternativas sustentáveis para a substituição de estruturas de produção e de consumo consideradas antigas.

As mudanças necessárias podem não ser as mesmas para as diferentes economias globais, no entanto, as novas tecnologias precisam ser acessíveis para os povos desfavorecidos e devem ser desenvolvidas levando-se em consideração as pessoas (SCHUMACKER, 1979).

As novas tecnologias precisam remover as principais fontes de privação de liberdade das pessoas como a pobreza, a tirania, a carência de oportunidades econômicas, a destituição social sistemática, a negligência dos serviços públicos, a intolerância e a interferência excessiva de Estados repressivos (SEN, 2000).

O rumo da transição das economias globais para o baixo carbono deverá ser influenciado pelas vias que forem abertas aos países em desenvolvimento para que não fiquem na dependência de transferências de tecnologias injustas e que possam se 
beneficiar de esquemas de cooperação na montagem de seus próprios sistemas de ciência, tecnologia e inovação (VEIGA, 2009).

Diante dos possíveis impactos na economia e nas condições de vida do planeta, o aquecimento global que é uma consequência dos padrões insustentáveis de produção e de consumo vigentes, definitivamente, insere o tema meio ambiente na dimensão estratégica social, econômica e ambiental, no âmbito global. Adicionalmente, os representantes de governo, setor privado e sociedade civil, concentram esforços no sentido de adotar novas ações de redução das emissões de gases de efeito estufa, com medidas que podem alterar inclusive os padrões de produção e de consumo das populações.

Torna-se necessário recuperar as mudanças de longo prazo com a promoção do consumo sustentável. $O$ consumo de 1,2 bilhões dos seres humanos mais ricos da terra representa $75 \%$ das emissões de gases de efeito estufa do planeta. Esses consumidores precisam deixar de ser considerados como parte do problema e passar a ser considerados como parte das soluções possíveis (MUNASINGHE, 2010).

É preciso que ocorra a mobilização efetiva de consumidores e de produtores para o alcance da sustentabilidade ambiental e da ME de processos e de produtos. Os padrões de produção e de consumo precisam ser orientados no rumo da sustentabilidade para que, dentre outros efeitos, diminuam as emissões de carbono para a atmosfera (SPAARGAREN, 1997).

A ME considera, dentre outras suposições, que a ciência e a tecnologia modernas desempenham papéis centrais na condução da reforma ambiental por meio das inovações ambientais preventivas que propiciam a possibilidade do alcance simultâneo de metas ambientais e de metas econômicas (MILANEZ, 2009).

A proposta teórica da ME teve origem na Europa Ocidental, com os trabalhos do sociólogo alemão Joseph Huber, no início da década de 1980 e defendia que o principal problema das sociedades industriais contemporâneas estava relacionado com a colonização da "socio-esfera" (o mundo da vida) e da "eco-esfera" (a natureza) pela "tecno-esfera"(o sistema industrial e o mercado) (HUBER, 1986).

$\mathrm{Na}$ fase inicial o foco estava no aumento da eficiência das atividades industriais por meio da redução do consumo de recursos naturais e pela diminuição dos custos com os instrumentos que remediavam os problemas ambientais. O principal argumento da ME era a necessidade de inovação tecnológica orientada para o meio ambiente como uma estratégiachave para a superação de problemas ambientais.

A ME sublinha a importância crescente das dinâmicas econômicas e de mercado na reforma ecológica e o papel importante dos inovadores, empresários ou outros agentes econômicos que se somam com novos atores e interagem de modo complexo com os 
movimentos ambientalistas e com as agências estatais que são encarregadas direta ou indiretamente, da elaboração das políticas públicas de meio ambiente.

Como resultado dessa interação entre diferentes atores, a teoria foi ampliada e reforçou o diálogo com a engenharia, as ciências políticas e a sociologia. Dessa forma, pesquisadores da ME passaram a demonstrar de forma teórica e empírica, que a produção industrial e o consumo, tanto nos países desenvolvidos como em alguns países em desenvolvimento, têm sofrido uma transformação radical que é induzida pelo crescente interesse social em relação à proteção ambiental.

Nesse contexto, a ME leva em consideração as tendências de dinamização das relações econômicas, políticas e sociais provocadas pela globalização e tenta oferecer as bases conceituais para uma análise desse processo de transformação denominado "reestruturação ecológica” ou "modernização ecológica da produção e do consumo".

Dessa forma, um dos objetivos principais da ME é formular uma teoria social consistente para compreender e explicar como e até que ponto, os processos de produção e de consumo nos tempos atuais estão sendo transformados e direcionados para o alcance de um desempenho ambientalmente mais sustentável (OLIVIERI, 2009).

No contexto da ME da produção e do consumo uma das metodologias propostas é a Análise do Ciclo de Vida (ACV), que tem caráter científico, utiliza ferramentas integradas e auxilia os produtores a reexaminar a cadeia de valor, desde a extração de matérias-primas até a disposição do produto para o uso do consumidor final. Além disso, ajuda a identificar onde a inovação pode melhorar a sustentabilidade da produção e envolver de forma efetiva o setor privado na procura de processos produtivos com menores impactos negativos sobre o meio ambiente.

Para Porter e van der Linde (1995), as empresas competitivas em nível internacional, não são aquelas que possuem os menores preços para os insumos ou que trabalham com maior escala, mas aquelas que possuem capacidade para melhorar processos e produtos e inovar continuadamente. O paradigma da competitividade dinâmica estabelece que a inovação adotada pelas empresas, em geral, compensam parcialmente, ou até integralmente, os custos de conformidade dos seus processos produtivos para atenderem às regulações ambientais.

A rotulagem ambiental está inserida nesse contexto de $\mathrm{ME}$ da produção e do consumo, da competitividade dinâmica das empresas e da necessidade de inovação tecnológica orientada para o meio ambiente como uma estratégia-chave para a superação de problemas ambientais.

Trata-se de uma ferramenta de mercado baseada em informações precisas e verificáveis que são disponibilizadas nos rótulos das embalagens dos produtos para que os consumidores tenham a possibilidade de escolher produtos com menor impacto ambiental 
em relação aos produtos concorrentes e disponíveis no mercado. A rotulagem ambiental estimula a inovação espontânea e a competição ambiental entre empresas (IPEA, 2011).

É, simultaneamente, um instrumento econômico e um instrumento de comunicação que busca difundir informações com o objetivo de alterar positivamente, padrões de produção e de consumo, e de aumentar a consciência dos consumidores e produtores para a necessidade do uso dos recursos naturais de forma mais responsável. Permite que as empresas com maior propensão para a inovação usufruam dos benefícios decorrentes da transformação de seus processos produtivos na direção de uma maior sustentabilidade ambiental.

Para Erskine e Collins (1997), apesar de o mecanismo da rotulagem ambiental ganhar espaço global, muitos programas de rotulagem ambiental não vêm obtendo êxito devido às limitações e aos efeitos diversos em seu desenvolvimento, tal como a dificuldade de estabelecer critérios objetivos e cientificamente aceitos, que identifiquem produtos "ambientalmente amigáveis" em uma dada categoria. A falta de padrões ou definições claras de critérios ambientais dificulta a adoção da rotulagem ambiental por parte das empresas.

A rotulagem ambiental está exatamente no cruzamento das questões ambientais com as questões comerciais. Corresponde ao resultado de uma abordagem de negócios que objetiva tirar vantagem das forças de mercado para influenciar o consumidor bem informado e para conquistar posição privilegiada em um nicho de mercado potencialmente lucrativo (ROYON, 1998).

De acordo com Wells (2006), os rótulos ambientais levam os consumidores a procurar símbolos e não os informam a respeito dos aspectos ambientais específicos dos produtos que compram. A consciência sobre o significado da rotulagem ambiental ainda é baixa entre consumidores e revendedores, particularmente em países em desenvolvimento, como o Brasil, que carecem de campanhas educativas neste sentido.

O número de empresas que consideram o rótulo ambiental um fator essencial para a elaboração de suas estratégias comercial e industrial, aumenta progressivamente. Tal interesse assume um impacto ainda maior no contexto atual da globalização dos mercados, no qual a rotulagem ambiental de um determinado produto é considerada um meio eficaz de proteção dos mercados domésticos e uma ferramenta importante para a conquista de mercados externos (HUSSAIN, 2009).

Nessa linha de pensamento, para Dias (2008), a rotulagem ambiental pode servir como medida protecionista no âmbito do comércio internacional, com a criação de barreiras comerciais. A formulação dos critérios pode se dar de forma arbitrária, realçando preferencialmente parâmetros ambientais alcançados com maior facilidade pelos produtos domésticos da parte interessada em propor o rótulo ambiental. 
A rotulagem ambiental, segundo Gallastegui (2001), informa os consumidores sobre os efeitos dos processos produtivos de produtos e serviços no meio ambiente. Tem dois objetivos principais: prover os consumidores com informações adicionais sobre os efeitos do consumo no meio ambiente, gerando mudanças na direção de padrões de consumo menos agressivos ao meio ambiente e encorajar os produtores, setores governamentais e outros agentes para desenvolver padrões e normas ambientais para produtos e serviços.

No entanto, o esforço para adaptar o processo produtivo às normas, aos padrões e aos critérios estabelecidos para a rotulagem ambiental pode provocar aumento de custo para as empresas. Além disso, existe um custo para a obtenção e para a manutenção dos selos em programas reconhecidos, tais como taxas de inscrição, taxas anuais, custos de testes, vistorias e auditorias. Tudo isto pode se refletir no preço dos produtos (BLEDA; VALENTE, 2009).

O interesse pessoal em abordar a questão da rotulagem ambiental no contexto da ME advém da experiência profissional, decorrente de um conjunto de atividades desenvolvidas no âmbito de um Projeto de Cooperação entre o governo brasileiro, representado pelo Ministério do Desenvolvimento, Indústria e Comércio Exterior (MDIC), o Programa das Nações Unidas para o Meio Ambiente (PNUMA) e a Comissão da União Européia (UE). Tal Projeto foi desenvolvido no período de 2007 a 2011 e além do Brasil, contou com a participação de representantes da África do Sul, China, Índia, México e Quênia.

O objetivo geral era desenvolver a rotulagem ambiental em países emergentes para que seus produtos fossem mais competitivios em mercados globais. A idéia era capacitar, formar e informar agentes governamentais, representantes do setor privado e da sociedade civil e aumentar a conscientização desses países em relação aos benefícios advindos da adoção da rotulagem ambiental.

Os coordenadores internacionais convidaram a Secretaria de Comércio Exterior (SECEX), do MDIC, para que fosse a representante do governo brasileiro no referido projeto em função da sua ligação com o comércio exterior brasileiro. A coordenação nacional do referido projeto foi delegada para meu cargo. Somaram-se a este conjunto de experiências, os conhecimentos sobre relações internacionais, adquiridos no Departamento de Relações Internacionais da UNB e os conhecimentos sobre meio ambiente e interdisciplinaridade adquiridos nos cursos de mestrado e de doutorado no Centro de Desenvolvimento Sustentável da mesma universidade (CDS/UNB).

Nesta perspectiva, a pesquisa de campo foi realizada no período de 2007 a 2011, que correspondeu ao período de desenvolvimento das atividades relativas ao Projeto de Cooperação. Foi constituída por cursos de capacitação sobre rotulagem ambiental e programas de rotulagem ambiental que foram ministrados principalmente por representantes 
da União Européia e do Global Ecolabelling Network (GEN) e Workshops nacionais e internacionais para atender às demandas específicas dos setores governamentais, privados e da sociedade civil dos países envolvidos no processo.

Adicionalmente foram feitas visitas regulares à fábrica de papel e celulose de Luiz Antônio, no interior do estado de São Paulo e pertencente ao grupo International Paper do Brasil Ltda (IP), que foi o representante do setor privado brasileiro no referido Projeto de Cooperação.

As informações de campo foram coletadas desde as primeiras atividades desenvolvidas em 2007 até o momento final do Projeto que culminou com a obtenção do rótulo do Programa de Rotulagem Ambiental da União Européia (Flower) e do rótulo do Programa de Qualidade Ambiental da ABNT (Colibri), pela fábrica de Luiz Antônio,

Os dados de campo foram na sua maioria coletados diretamente na referida fábrica e com auxílio de seus funcionários e complementados com dados secundários que foram disponibilizados pela Associação Brasileira de Celulose e Papel (BRACELPA) e pela Associação Brasileira Técnica de Celulose e Papel (ABTCP), por meio de suas respectivas páginas eletrônicas.

Foram feitas ainda, entrevistas abertas e conversas livres que permitiram perceber os pontos de vista, concepções, opiniões e interpretações de diferentes representantes dos países participantes e do Brasil como do setor privado (representantes e funcionários das empresas e associações de classe), do setor governamental (representantes de Ministérios como o MDIC, Ministério do Meio Ambiente (MMA), Ministério de Ciência, Tecnologia e Inovação (MCTI) e Ministério de Relações Exteriores (MRE)), de Universidades (UNB, USP, URFJ), assim como da sociedade civil (Instituto Brasileiro de Defesa do Consumidor (IDEC)).

Esta tese contribui para melhorar a compreensão da ME no Brasil e sua relação com a rotulagem ambiental entendida como um instrumento de mercado e de informação para o consumidor no contexto de modernização dos processos de produção. Não faz parte do escopo empírico desta tese a análise da influência da ME e da rotulagem ambiental nos padrões de consumo.

Para contribuir com as pesquisas referentes ao tema, o objetivo geral dessa tese é responder as questões formuladas abaixo:

1. A ME contribui para explicar e comprender as mudanças necessárias nos padrões vigentes de produção e de consumo para padrões mais sustentáveis para a superação da crise ambiental?

2. A aplicação dos pressupostos da ME pelas empresas contribui para a mudança no padrão de produção?

3. A Rotulagem Ambiental pode ser considerada um instrumento da ME? 
4. A Rotulagem Ambiental efetivamente agrega competitividade aos produtos nacionais em mercados globais, incentiva a inovação ambiental e melhora o desempenho ambiental de processos produtivos?

No sentido de alcançar o objetivo geral, foram traçados alguns objetivos específicos:

- $\quad$ Avaliar os pressupostos básicos da ME;

- Analisar o conceito, os objetivos básicos, os tipos, o funcionamento da Rotulagem Ambiental e as principais características do Programa de Rotulagem Ambiental da União Européia (Flower) e do Programa de Qualidade Ambiental da ABNT (Colibri) e;

- Construir Panorama do setor de papel e celulose no Brasil para conhecer suas especificidades e características principais.

Para o alcance do objetivo geral e dos objetivos específicos, acima referidos, foi desenvolvida uma metodologia baseada em:

a) Pesquisas bibliográficas, com ênfase na teoria da Modernização Ecológica (ME), na Rotulagem Ambiental e sobre o setor de papel e celulose do Brasil;

b) Pesquisa de campo realizada na fábrica de Luiz Antônio, localizada no município de Luiz Antônio (SP) e pertencente ao grupo International Paper do Brasil Ltda (IP).

As etapas de desenvolvimento da Tese foram:

1. Pesquisa de Campo (Desenvolvimento do Projeto de Cooperação com duração de 4 anos e visitas regulares à fábrica de Luiz Antônio). Esta fase foi praticamente simultânea com a segunda fase.

2. Fundamentação teórica: pesquisa sobre a rotulagem ambiental;

3. Fundamentação teórica: pesquisa sobre a ME;

4. Pesquisa sobre trabalhos que tratavam, ou estavam relacionados, com o tema da ME e da rotulagem ambiental;

5. Sistematização e análise das informações e;

6. Tratamento dos resultados.

Justifica-se essa pesquisa porque se insere no âmbito das demandas frequentes de pesquisadores do tema como Young (2000), Spaargaren (2003), Mol (2005), Milanez (2006) e Olivieri (2009), dentre outros, que demandam pesquisas adicionais sobre a aplicação da ME em países localizados fora do continente Europeu e sobre a efetividade da rotulagem ambiental como instrumento de fortalecimento da inovação ambiental, do desempenho ambiental e da competitividade das empresas.

Embora a literatura sobre a ME e sobre a rotulagem ambiental seja abrangente, poucos trabalhos abordam a relação existente entre elas, como foi feito nesta tese. Para Chen, Lai e Wen (2006), a questão relacionada com o impacto da proteção do meio ambiente sobre a competitividade das empresas ainda não recebeu muita atenção por parte 
da comunidade acadêmica. Enquanto que para Pujari (2006), os aspectos ecológicos relacionados aos processos de inovação têm sido realizados por pesquisadores, mas em nível informal. A literatura existente carece de estudos empíricos que explorem como fazer produtos mais ecológicos que sejam bem sucedidos no mercado.

A tese tem uma abordagem teórica e uma abordagem empírica e está dividida em duas partes. A primeira parte contém 3 capítulos. No capítulo 1 são apresentados os antecedentes da ME com a discussão dos principais acontecimentos que foram fundamentais para a intensificação das discussões sobre o meio ambiente e a necessidade de harmonização entre o desenvolvimento econômico e as questões ambientais, no fim da década de 1960 e início da década de 1970.

No capítulo 2 são discutidos os principais pressupostos da ME. A fim de realizar o estudo empírico, a tese adota uma perspectiva estreita da ME. Para efeitos desta pesquisa, ME é definida como o uso de inovações tecnológicas ambientais nos processos produtivos que, simultaneamente produzem benefícios ambientais com a redução do consumo de recursos e das emissões atmosféricas e aumentos de competitividade das empresas. No entanto, a discussão realizada neste capítulo também inclui outros elementos como os sociais e os organizacionais que compoem a ME.

Os subsídios teóricos dos capítulos 1 e 2 desta pesquisa foram utilizados para responder a primeira e a segunda pergunta proposta.

No capítulo 3 é apresentada uma discussão sobre a rotulagem ambiental e é dada ênfase nas suas características, definição, escopo, tipos e na sua relação com a ME.

A parte empírica é composta pelo capítulo 4 no qual é apresentado o estudo de caso que avalia a aplicação da ME no setor de papel e celulose do Brasil, por meio da rotulagem ambiental. Trata-se do relato do processo de obtenção do Flower e do Colibri pela fábrica de Luiz Antônio, do grupo IP, no período de 2007 a 2011 para poder estampá-lo na embalagem de seu produto: o papel para cópia e impressão (papel offset chambri).

Neste capítulo a informação empírica é usada para avaliar os pressupostos teóricos e as hipóteses restantes da pesquisa. Optou-se pelo estudo de caso e não por outros tipos de metodologia, como por exemplo, estudo de painel, para poder utilizar além de dados numéricos, a experiência pessoal adquirida com as impressões dos participantes e as diferentes situações que foram enfrentadas durante a realização do referido Projeto de Cooperação e que contribuíram substancialmente para a conclusão desta pesquisa.

Ainda no capítulo 4 são apresentados os critérios ambientais aos quais a fábrica de Luiz Antônio se submeteu para obter o Flower em 2011 e a partir desta data é avaliado o seu desempenho ambiental e comparado com outra fábrica do grupo IP e com duas outras fábricas do setor de papel e celulose pertencentes ao grupo Susano Papel e Celulose. As empresas que são comparadas com a fábrica de Luiz Antônio não possuem o Flower, nem o 
colibri. Após a elaboração do capítulo 4 foram respondidas as duas últimas perguntas da Tese.

Finalmente, foram elaboradas as considerações finais da Tese. Os resultados dessa pesquisa, levando-se em consideração os limites encontrados, permitem afirmar que de forma geral, a aquisição do rótulo ambiental europeu contribuiu para o aumento das vendas da fábrica de Luiz Antônio no mercado internacional e imprimiu sensível melhora no desempenho ambiental do seu processo produtivo.

Salienta-se que as conclusões relacionadas com os benefícios da rotulagem ambiental foram obtidas somente da análise da aquisição do Flower, pois apesar de ter também obtido o Colibri, a fábrica de Luiz Antônio ainda não o utiliza nas embalagens de seus produtos no mercado doméstico. Este fato impossibilitou a análise empírica do comportamento do consumidor brasileiro em relação à rotulagem ambiental.

Confirmou-se que a ME, apesar de inúmeras limitações, pode ser utilizada com uma teoria para explicar e compreender as mudanças nos padrões de produção vigentes para padrões mais sustentáveis e que a aplicação de seus pressupostos pelas empresas contribuem para alterar padrões de produção.

Corroborou-se a premissa de que a rotulagem ambiental é um instrumento da ME que estimula a inovação, agrega competitividade aos produtos nacionais em mercados globais e melhora o desempenho ambiental das empresas. No entanto, torna-se necessário que mais pesquisas sejam realizadas para avaliar a aplicação da ME no Brasil e que outros tipos de empresas e de setores da economia nacional sejam avaliados. 


\section{Capítulo 1. ANTECEDENTES POLÍTICOS DA MODERNIZAÇÃo ECOLÓGICA}

\subsection{Introdução}

Existem diferentes análises para os eventos que viabilizaram a emergência da ME no início da década de 1980 e diferentes ênfases que foram dadas para as suas principais características, pelos estudiosos do tema. Esta tese considera que tais fatos estão diretamente relacionados com as discussões sobre as questões ambientais no contexto das sociedades industriais ocidentais, notadamente a partir do fim da década de 1960 e início da década de 1970.

No entanto, as questões ambientais e a degradação do meio ambiente já eram temas presentes nos debates de alguns países e de setores específicos da sociedade desde o início do século passado. Para um melhor entendimento dessas questões ambientais e da emergência da ME foram considerados três períodos da história.

O primeiro período compreende o princípio do século $X X$ e se estende até o fim da década de 1960. Preocupou-se principalmente, com a degradação das paisagens naturais em função do aumento da industrialização e da expansão urbana. Nessa fase não houve o questionamento das estruturas da sociedade industrial emergente e nem das questões sociais vinculadas a essas estruturas.

A ênfase dada pelos pesquisadores concentrou-se nas demandas para a proteção das áreas naturais ricas em termos de biodiversidade devido à devastação que era proporcionada pela rápida industrialização e pelo avanço das cidades. As reservas naturais e as áreas semiprotegidas foram típicos exemplos desse período, na maioria dos países industrializados do ocidente.

O segundo período compreende o fim da década de 1960 e início da década de 1970 e se estende até a segunda metade da década de 1980. Foi representado pelo ambientalismo que defendia a idéia de uma reorganização da ordem social como uma condição sine qua non para o alcance de uma sociedade ecologicamente sadia.

Contudo, a mudança social reivindicada e inspirada na ecologia repercutiu somente em uma pequena parte da sociedade industrial. Mesmo assim, destacou-se nesse período a criação dos departamentos governamentais para o meio ambiente nos países industrializados, a elaboração de legislação e de planejamento ambiental específico e um aumento significativo das ONGs.

Apesar da adoção de muitas medidas com o objetivo de combater a degradação ambiental e de algumas serem realmente implementadas, a maioria das instituições da 
modernidade (Estado, Mercado, Ciência e Tecnologia) priorizaram medidas cujo objetivo era o alcance do progresso econômico.

Os escassos resultados da reforma industrial que foram obtidos nas décadas de 1970 e de 1980 não se refletiram nas teorias sociais dominantes da época, no que diz respeito às reflexões sobre a degradação ambiental e a reforma ambiental. Tais teorias e especialmente, a teoria dos neomarxistas e as chamadas teorias da desindustrialização concentraram-se na explicação da intensificação da crise ambiental e na estagnação da reforma ambiental. Para esses teóricos a reforma ambiental tinha fracassado.

Os Neomarxistas defendiam que o modo de produção capitalista era a causa principal da crise ambiental e argumentavam que o modo de produção capitalista não poderia superar a crise ambiental e a degradação ambiental seria o seu resultado. Os defensores da desindustrialização ou os teoristas da contraprodutividade como Bahro, Ulrich e Gorz, por sua vez, afirmavam que a ênfase estava na influência dos avanços tecnológicos e industriais ligados ao modo de produção capitalista e que contribuíam para a degradação ambiental.

O sistema industrial era o responsável pela crise ambiental. Neste sentido, o debate dos anos 1960 sobre qual era a característica central das sociedades ocidentais, se o industrialismo ou o capitalismo, foi prolongado para os círculos ambientais na década de 1970.

O terceiro período teve início a partir da segunda metade da década de 1980 e foi caracterizado pela elaboração do Relatório Brundtland (WCED, 1987) e pela realização da Conferência das Nações Unidas para o Meio Ambiente e o Desenvolvimento (1992). Para Buttel (1987), existem diferenças importantes entre o ambientalismo da década de 1970 e o aumento da consciência ambiental percebido no fim da década de 1980 e início da década de 1990. A natureza dos debates e as principais idéias que alimentavam os debates dessa última década se diferenciavam significamente dos empregados na década de 1970.

Todavia, o terceiro período analisado não se diferenciava dos demais apenas pela natureza e conteúdo dos debates. Nesse período teve início as primeiras transformações da ordem institucional induzida pelo meio ambiente, nas sociedades industriais. Essas transformações tinham como objetivo proteger o meio ambiente de forma efetiva e se diferenciavam da forma inadequada com a qual os ambientalistas da década de 1970 conduziram a reforma ambiental.

A ME surgiu então, no terceiro período analisado como uma idéia que se opunha às falhas cometidas nos períodos anteriores em relação à condução das questões ambientais. Embora sua história data do início da década de 1980, as idéias principais da ME surgiram com a publicação de acadêmicos da ciência política e da sociologia ambiental, a partir do início da década de 1990. 
Algumas dessas idéias defendiam que a ME não prioriza reflexões sobre a contínua sobrecarga da base de sustentação do planeta, mas se concentra na reestruturação induzida pelo meio ambiente dos processos de produção e de consumo.

Cabe ressaltar uma diferença adicional entre o terceiro período e o segundo período no que diz respeito ao entendimento sociológico das questões ambientais. Durante e após o segundo período, a Teoria Geral Sociológica foi fortemente influenciada pelas questões ambientais, porém o seu entendimento sociológico sobre a degradação ambiental e sobre a reforma ambiental, eram limitados. No entanto, a década de 1990 assinalou um aumento do comprometimento da Teoria Geral da Sociologia com os problemas ecológicos (por exemplo, Giddens) e algumas das teorias foram construídas em torno das questões ambientais globais, como a Teoria da Sociedade de Risco, de Beck (MOL, 1995).

A ME e outras teorias do terceiro período aproveitaram-se desse aumento de atenção para as questões ambientais por parte das Teorias Sociais e da sociedade em geral, para ganharem mais atenção e popularidade.

Em decorrência da importância dos acontecimentos e da proximidade com o período da emergência da $\mathrm{ME}$, assume-se nesta pesquisa que o segundo período e o terceiro período acima referidos, explicam com maior clareza as causas da ME. Dessa forma será dada ênfase para fatos que caracterizaram esses períodos e que contribuíram para a construção das idéias e pressupostos da ME.

Com o objetivo de esclarecer a dinâmica política da ME torna-se necessário um retorno para pelo menos o início da década de 1970 quando o meio ambiente tornou-se um importante tópico político no âmbito das sociedades industriais ocidentais.

Nesta tese foi dada ênfase para algumas características da política de controle da poluição adotada na década de 1970 pelos países industrializados, notadamente da Europa Ocidental e para as profundas mudanças que ocorreram no movimento ambientalista do mesmo período, por considerar esses dois tópicos de grande importância para a compreensão efetiva da emergência da ME.

\subsection{A resposta política para as questões ambientais na década de $\mathbf{1 9 7 0}$}

No fim da década de 1960 e início da década de 1970, as discussões sobre a proteção do meio ambiente com ênfase no controle da poluição, tornaram-se a questão central da agenda política das sociedades industriais ocidentais.

A chuva ácida, as mudanças climáticas, a contaminação do meio ambiente por produtos químicos, a necessidade da conservação da água em condições para o consumo e as questões ligadas ao manejo de resíduos tóxicos, deixaram de ser preocupações 
específicas de ambientalistas ou de acadêmicos para se tornarem temas de interesse da mídia, dos partidos políticos, dos cidadãos e dos governos (WEALE, 1992).

Nesse período houve um aumento expressivo do interesse público pelas questões referentes à politica ambiental principalmente, nos países industrializados da Europa Ocidental e nos países da América do Norte. Tal aumento foi impulsionado pela mídia com coberturas jornalísticas de eventos sobre o meio ambiente e pelas campanhas dos grupos de pressão, formados principalmente por ambientalistas radicais.

Acontecimentos como o incêndio do leito do Rio Cuyahuga, nos arredores de Cleveland, nos Estados Unidos, em junho de 1969, devido à intensa descarga de produtos químicos em seu leito e o naufrágio do petroleiro Torrey Canyon com o vazamento de 120.000 toneladas de petróleo no mar, no extremo sudoeste da Inglaterra, desempenharam papel muito importante na conscientização pública da época.

Bursztyn e Persegona (2008), afirmam que alguns eventos ambientais de décadas anteriores não foram percebidos pelo ativismo político. Destacam-se os incidentes de Donora, na Pennsylvania, em 1948 quando 20 pessoas morreram devido a um nevoeiro sulfuroso e uma chuva de granizo radioativa que ocorreu na Austrália, próxima ao local onde os ingleses realizavam seus primeiros testes nucleares.

Pode-se afirmar que por trás dessa onda de ativismo político ambiental estavam mudanças estruturais ocorridas em décadas anteriores nos padrões de organização social e de relações sociais como (WEALE, 1992):

- Os avanços da qualidade do ensino e do nível de informação da população que viabilizaram um público atento para absorver mensagens como a de Rachel Carson em seu livro Primavera Silenciosa de 1962;

- A crescente e ampla cobertura internacional pelos meios de comunicação, de eventos de degradação do meio ambiente que intensificaram rapidamente o debate e a propagação de idéias em diferentes regiões da Terra;

- Os efeitos do longo boom do pós-guerra que propiciaram uma quantidade sem precedentes de bens e commodities para cidadãos em países em desenvolvimento que tiveram que lidar com a melhoria da qualidade de vida e com a deterioração do meio ambiente.

Os grupos de pressão e a opinião pública em geral reivindicavam que os governos respondessem politicamente e de forma efetiva aos problemas de degradação ambiental que aumentavam significativamente nos países industrializados devido à intensificação da industrialização. Os principais problemas de degradação do meio ambiente que exigiam uma resposta política dos governos e que eram frequentemente observados pelos ativistas ambientais estão no Quadro a seguir. 
Quadro 1.1. Exemplos de problemas ambientais da política de controle da poluição.

\begin{tabular}{|c|c|c|c|}
\hline Problemas & Principais poluentes & $\begin{array}{l}\text { Atividades humanas } \\
\text { relacionadas }\end{array}$ & Efeitos esperados \\
\hline Mudanças climáticas & $\begin{array}{l}\text { Dióxido de Carbono, metano, } \\
\text { CFCs. }\end{array}$ & $\begin{array}{l}\text { Queima de combustíveis } \\
\text { fósseis }\end{array}$ & $\begin{array}{l}\text { Vários e incertos - aumento da } \\
\text { temperatura da Terra, aumento do nível } \\
\text { do mar, desertificação. }\end{array}$ \\
\hline $\begin{array}{l}\text { Diminuição da camada de } \\
\text { Ozônio }\end{array}$ & CFCs & Uso de aerosóis & $\begin{array}{l}\text { Perda da função de proteção da } \\
\text { atmosfera contra a radiação ultravioleta. }\end{array}$ \\
\hline Acidificação & $\begin{array}{l}\text { Enxofre, Dióxidos, Óxido de } \\
\text { Nitrogênio, amônia, } \\
\text { Hidrocarbonetos. }\end{array}$ & $\begin{array}{l}\text { Queima de combustíveis } \\
\text { fósseis }\end{array}$ & $\begin{array}{l}\text { Deterioração da saúde humana, de } \\
\text { florestas, rios e lagos. }\end{array}$ \\
\hline Eutrofização & Fosfatos, Nitratos & Uso de fertilizantes & $\begin{array}{l}\text { Enriquecimento excessivo dos rios } \\
\text { levando ao crescimento de algas }\end{array}$ \\
\hline $\begin{array}{l}\text { Dispersão de produtos } \\
\text { químicos e resíduos nos } \\
\text { mares e oceanos }\end{array}$ & $\begin{array}{l}\text { Esgoto, pesticidas, metais } \\
\text { pesados. }\end{array}$ & $\begin{array}{l}\text { Aglomerações habitacionais, } \\
\text { esgoto não tratado, disposição } \\
\text { de resíduos industriais. }\end{array}$ & $\begin{array}{l}\text { Perda de espécies marinhas, perdas } \\
\text { econômicas dos pescadores, perdas com } \\
\text { turismo. }\end{array}$ \\
\hline $\begin{array}{llr}\text { Dispersão } & \text { de } & \text { produtos } \\
\text { químicos } & \text { e resíduos nos } \\
\text { solos } & \text { e } & \text { àguas } \\
\text { subterrâneas } & \\
\end{array}$ & $\begin{array}{lll}\text { Pesticidas } & \text { e } & \text { Resíduos } \\
\text { Tóxicos. } & & \\
\end{array}$ & $\begin{array}{l}\text { Disposição de resíduos } \\
\text { industriais e domésticos }\end{array}$ & $\begin{array}{l}\text { Perda de espécies e contaminação dos } \\
\text { resursos hídricos }\end{array}$ \\
\hline $\begin{array}{l}\text { Dispersão de produtos } \\
\text { químicos e resíduos na } \\
\text { àgua doce }\end{array}$ & $\begin{array}{l}\text { Nitratos, fosfatos, chuva } \\
\text { ácida. }\end{array}$ & $\begin{array}{l}\text { Agropecuária, queima de } \\
\text { combustíveis fósseis. }\end{array}$ & Perda de especies \\
\hline Poluição urbana & Fumaça, barulho & Tráfego, Produção & Stress, poeira, doenças físicas. \\
\hline
\end{tabular}

Fonte: Weale (1992)

Para responder às demandas públicas que reivindicavam posicionamento dos governos em relação aos problemas causados pela poluição nos países industrializados, foram elaboradas políticas ambientais que tinham por objetivo controlar e mitigar, principalmente, os efeitos dos poluentes na atmosfera e nas águas. Para Weale (1992), as principais características dessas respostas políticas foram:

1 - A elaboração de legislação específica mais rigorosa para o controle de poluentes e de substâncias tóxicas e a elaboração de legislação para o uso do ar e da água.

Exemplos dessas legislações foram o Ato do Ar puro nos Estados Unidos em 1970, o controle federal de emissões, na Alemanha Ocidental, em 1974 e o Controle da Poluição no Reino Unido também em 1974.

As políticas de resposta envolveram a criação de novas organizações e instituições e a readaptação de instituições já existentes em relação às novas propostas. Foram exemplos, a Lei sueca de Proteção Ambiental de 1969 que delegou ao Conselho Nacional de Proteção Ambiental o poder necessário para desenvolver a política; a Agência Norteamericana de Proteção Ambiental (EPA) que foi criada em 1970 e a reformulação do Ministério do Interior da Alemanha, que passou também a se responsabilizar pelas questões ambientais, em 1969. 
Ressalta-se que uma característica importante dessas novas instituições foi a criação de órgãos de assessoria técnica e científica de alto nível como o Conselho de especialistas em Meio Ambiente nos EUA, a Comissão Real sobre o Meio Ambiente no Reino Unido, e a Secretaria de Especialistas em Meio Ambiente, na Alemanha. Cada uma dessas iniciativas nacionais refletiram as circunstâncias e a história do sistema político no qual foram tomadas.

As legislações e as políticas variaram muito entre os diferentes países. Na Suécia, as iniciativas voltadas para o controle da poluição atmosférica refletiam preocupação com a viabilidade econômica e tecnológica e possibilitavam a negociação direta entre funcionários públicos e representantes da indústria para aplicação de normas específicas. Já, nos Estados Unidos, a legislação de poluição atmosférica priorizava a determinação dos patamares permitidos das emissões de poluentes sem muita preocupação com a viabilidade econômica e tecnológica e foi implementada em um contexto de muita participação pública.

Apesar dessas importantes diferenças, também existiam semelhanças, nas estratégias de controle da poluição adotadas pelos diferentes países. Em parte, essas semelhanças refletiam considerável compartilhamento dessas políticas. As Inovações desenvolvidas e as iniciativas tomadas pelos Estados Unidos eram de particular importância para os outros países e os elementos-chave da abordagem americana eram levados em consideração por governos europeus (TAYLOR, 1984).

Pode-se citar como exemplo o fato de o Conselho de Qualidade Ambiental dos Estados Unidos ter sido modelo para o Conselho de Especialistas Ambientais da Alemanha. A ideia de avaliação de impactos ambientais elaborada pelos americanos, por exemplo, foi amplamente utilizada por outros países.

A comparação entre a evolução das políticas ambientais elaboradas nos diferentes países permite concluir que tinham um número significativo de características em comum, tanto no tipo de resposta quanto na estrutura de cada uma. As datas muito próximas dos principais avanços legislativos e políticos ocorridos nesses países denotam um determinado padrão.

Em função da crescente preocupação pública e política verificada na metade da década de 1970, os governos criaram um conselho de peritos independentes e um órgão de característica burocrática para o desenvolvimento da política ambiental. As propostas foram variadas (WEALE, 1992).

O Presidente Nixon, nos Estados Unidos, criou o conselho de qualidade ambiental em 1969, cujo objetivo era mostrar ativismo presidencial simbólico e visível, apesar de um congresso descontente. Já Harold Wilson, na Grã Bretanha, criou a Comissão Real Permanente sobre a poluição ambiental, que foi percebida como a expressão da tradição bem estabelecida de interdependência informal na Grã-Bretanha entre a elite científica e a elite política (TAYLOR, 1984). 
Apesar dessas diferenças, a lógica dessas respostas iniciais foi identificar uma área distinta da política pública com conhecimento e instituições próprias para a condução da discussão pública. Para que a política do controle da poluição ambiental pudesse ser praticada ela precisava ser inventada e isso involveu a criação de instituições relevantes, como os ministérios ou departamentos de meio ambiente, em vários países.

As mudanças no mecanismo da política nem sempre corresponderam à criação de um ministério do meio ambiente independente. Em alguns casos foi feita uma remontagem de órgãos burocráticos com o agrupamento de seções administrativas previamente separadas e estabeleceram alguma unidade ou agência cuja finalidade era dar direção central para a política. A criação de ministérios independentes teve amplas consequências que envolveram desde as manobras políticas para equilíbrio de posições e dos deveres dos ministros desses ministérios até as discussões para a composição dos gabinetes de coalizão política.

As instituições do meio ambiente foram criadas, mas não se efetivaram como órgãos responsáveis e competentes para lidar com os problemas das políticas ambientais e do controle da poluição. O Departamento de Meio Ambiente criado em 1970, pelo governo inglês só funcionou efetivamente como tal, em 1990, portanto vinte anos depois. Na Alemanha, algumas atividades de controle da poluição foram concentradas no Ministério do Interior e somente dezesseis anos depois é que foi criado o Ministério do Meio Ambiente, sob considerável pressão política e logo após o acidente nuclear de Chernobyl, na Ucrânia.

Para Hajer (1995), essa variação na velocidade e na estrutura da resposta política dos países industrializados deveu-se a uma série de fatores que influenciaram a forma assumida pelas máquinas governamentais encarregadas pela mudança. Contudo, também existiram semelhanças relacionadas com o tempo que essas mudanças levaram para ocorrer e para o endentimento dos tomadores de decisão que a reorganização na máquina do governo era uma condição necessária para futuros avanços políticos e valiosa resposta dos políticos para a opinião pública.

As respostas políticas substantivas também mostraram determinado padrão. As inovações legislativas começaram em 1970, com as questões de poluição das águas superficiais e em 1971 com a poluição atmosférica. Em alguns casos foi possível elaborar a nova legislação tendo como base as políticas e as estruturas de controle da poluição ambiental que já existiam. O controle dos produtos químicos foi inserido na agenda legislativa em 1976, seguido pelo controle das instalações de eliminação de resíduos.

Nessa época, a contaminação da água e do ar por poluentes foram os efeitos mais perceptíveis da poluição ambiental e havia interesses bem estabelecidos nos setores da sáude pública que se envolveram nas discussões dos efeitos da poluição ambiental no bem estar das populações. A percepção seletiva desses avanços políticos foi muito ampla já que 
alguns temas importantes foram incluídos muito tarde na agenda da política de controle da poluição (HAJER, 1995).

Para Bursztyn e Persegona (2008), um desses temas foi a poluição dos solos, questão para a qual, Carson chamou a atenção, na década de 1960, embora não tenha provocado avanços legislativos significativos. O livro "Primavera silenciosa" foi um dos primeiros que se preocupou com a conscientização de que os homens e os animais estão em interação constante com o meio ambiente em que vivem e pela primeira vez, argumentou sobre a necessidade de regulamentar a produção industrial para proteger o meio ambiente. A proteção do solo somente foi incluída em legislação específica, na Holanda, em 1982.

Outras características das respostas políticas, de acordo com (Weale, 1992), foram:

2 - O processo de atenção seletiva.

A baixa prioridade concedida para algumas questões referentes à poluição ambiental e a alta prioridade dada para outras questões provocaram limitações no processo de elaboração da política.

3 - O uso de estratégias regulatórias administrativas tradicionais.

A regulação por meio de regras legais era a norma. O significado dessa abordagem variou de país para país dependendo das convenções constitucionais e da cultura política local. Nos Estados Unidos e na República Federal da Alemanha, em ambos os sistemas políticos nos quais o processo de formulação de leis esteve baseado, havia condições para revisão legal de normas e de decisões administrativas já existentes, enquanto que no Reino Unido e na Suécia havia preferência por ampla discricionariedade administrativa e estreitas relações de trabalho entre os setores responsáveis pela fiscalização e os setores que seriam regulados.

Apesar dessas diferenças de estilo político, ficou estabelecido que o controle feito por meio de regras administrativas era a forma ideal para se tratar dos principais problemas. Apesar disso, outros instrumentos de controle como os instrumentos econômicos, foram temas de intensa discussão nas comunidades políticas relevantes, mas eles não ocuparam lugar central na resposta política da década de 1970.

4 - A propensão de déficit de implementação dos instrumentos de controle administrativo.

As normas rigorosas que foram elaboradas para o controle da poluição atmosférica e para o controle da poluição da água nos Estados Unidos em 1970 e em 1972, respectivamente, não cumpriram os prazos estabelecidos para a implementação. O próprio Presidente Carter alterou os limites do controle da poluição do ar em 1977 e no mesmo ano a Agência Norte Americana de Proteção Ambiental (EPA) reconheceu a falha no cumprimento dos prazos legais para a regulamentação das descargas tóxicas na água (TAYLOR, 1984). 
Similarmente, muitas das provisões da Lei Inglesa de Controle da Poluição Ambiental não foram implementadas e também o sistema alemão de controle da poluição apresentou déficit de implementação em grande parte de suas operações. O principal problema foi que a informação sobre a natureza do processo da regulamentação estava com o operador e não com a agência regulatória (WEALE, 1992).

Os reguladores eram forçados a barganhar estratégias diversas com operadores como os prazos envolvidos e os investimentos em tecnologias de controle da poluição ambiental. Esse tipo de problema fez com que até a Alemanha, que possuia um sistema administrativo reconhecidamente eficiente, apresentasse o déficit de implementação das regulamentações.

No âmbito geral da política pública foram constatados resultados semelhantes. Essas características da regulamentação administrativa eram inerentes ao processo e não estavam restritas aos sistemas administrativos específicos. Foram observadas em países diversos como na Alemanha, no Reino Unido, na Suécia, nos Estados Unidos, na França, na Holanda e até na Índia (DOWING AND HANF, 1983).

5 - As permissões múltiplas

Outra característica era a questão das permissões múltiplas. O controle sobre as emissões de determinados produtos químicos no ar ou na água foi criado em função de problemas com tipos específicos de poluição. No entanto, os processos produtivos utilizados pelas indústrias emitiam diferentes tipos de poluentes assim como utilizavam diferentes tipos de manuseios de substâncias potencialmente perigosas.

$\mathrm{Na}$ medida em que a estratégia regulatória usava instrumentos administrativos, impunha aos fabricantes a necessidade de licença para funcionamento em função das várias formas específicas de poluição ambiental nas quais se envolviam. Dessa forma, existia a possibilidade das fábricas interromperem suas atividades em função de inspeções, frequentemente sem coerência e com custo significativo. Essa característica de execução administrativa foi uma conseqüência das estratégias regulatórias adotadas durante a década de 1970.

6 - Inexistência de dispositivos para monitorar os resultados das iniciativas políticas e legislativas adotadas.

Não foram desenvolvidos dispositivos específicos para fornecer retorno para os formuladores de política e mostrar as dificuldades enfrentadas por aqueles que estavam implementando as normas.

Os sistemas políticos e administrativos priorizavam determinados tipos de informações em detrimento de outros, não pelos méritos substantivos, mas porque a seleção era influenciada pelo conhecimento e pela especialização disciplinar de elites políticas e percepções de legitimidade. O governo britânico, em diversos setores políticos, 
frequentemente minimizava as evidências comportamentais e sociológicas em favor das ciências naturais ou econômicas (WEALE, 1992).

De forma similar, a administração alemã era composta por proficionais sensíveis às sutilezas da interpretação constitucional e legal, mas que não se interessavam por informações sobre a eficácia do regime adotado de controle da poluição. Não havia um mecanismo de avaliação para acompanhar o desempenho e fornecer informações aos formuladores políticos sobre eventuais correções futuras.

Na década de 1970, não havia preparação intelectual para as reformas administrativas necessárias. Sem instrumento adequado para avaliação do processo de formulação de política, foi difícil fornecer as informações necessárias para o desenvolvimento da política. Sintoma disso, foi a constatação de que a evolução da política em determinados momentos, era o produto de forças externas às instituições de decisão, estritamente definidas (YOUNG, 2000).

7 - O fracasso na implementação de algumas regulamentações.

Pode-se argumentar que a referida estratégia falhou tanto no que diz respeito à concepção quanto à execução dessas regulamentações.

8 - Isolamento da Política Ambiental

A política ambiental foi elaborada como uma área específica da política e definida com âmbito e direitos próprios com o objetivo de ser absorvida por outras áreas de interesse dos governos. A criação de novos ramos do governo ou agências administrativas exemplifica essa hipótese.

A EPA, por exemplo, foi criada para se tornar a parte do governo norte-americano responsável pelo controle da poluição. Foi dada pouca atenção para a criação de instituições que pudessem permitir a inclusão de considerações ambientais nas decisões de políticas públicas referentes aos setores de transportes, agricultura ou indústria. Fato que foi corroborado pelos problemas de poluição ambiental que foram atribuídos às práticas agrícolas.

Durante a década de 1980, ficou claro que a intensificação da agricultura foi responsávei, em grande parte, pela poluição da água e pelo processo de eutrofização do solo. Esses problemas poderiam ter sido antecipados e evitados por especialistas ambientais, porém a fragmentação de responsabilidades não permitiu que fossem abordados.

A intensificação da agricultura na União Européia, para Weale (1992), foi produto do desenvolvimento de política pública que incluiu a prática de subsídios agrícolas para os agricultores dos estados membros, com incentivos para a fertilisação das culturas e para a criação de animais. 
Além disso, a produção de alimentos no mundo desenvolvido reduziu a demanda por produtos importados do terceiro mundo, criando para os agricultores do terceiro mundo uma perspectiva de diminuição da renda. A partir dessas pressões surgiram pressões em relação à superpopulação e ao uso excessivo de recursos naturais.

A negligência da interpretação das questões ambientais no âmbito das políticas públicas teve implicações na identificação da solução para os problemas ambientais. Knoepfel e Weidner (1986), por meio de estudo sobre as políticas elaboradas para o controle das emissões de dióxido de enxofre, mostraram que o volume das emissões era função de variáveis econômicas e de outras políticas públicas, inclusive da própria política ambiental.

A resposta da década de 1970, de forma geral, priorizou a elaboração de legislação substantiva e o controle de determinados poluentes, sem qualquer preocupação com a integração dessas iniciativas com os problemas ambientais e com setores da política pública. Exceção foi a Lei Nacional de Política Ambiental dos Estados Unidos (NEPA), em 1969, que se diferenciou da maioria.

Taylor (1984), afirma que a principal contribuição dada por essa legislação não foi substancial, mas de ordem processual. As agências federais norte-americanas foram obrigadas a fazer avaliação detalhada dos impactos ambientais de suas ações. Considerado como requisito modesto no âmbito das iniciativas políticas, a referida lei deu impulso significativo para a reorientação das atitudes e das prioridades dos departamentos do governo norte-americano que não tinham o meio ambiente como foco principal.

A elaboração da NEPA teve efeito positivo e significativo por vários anos. Em particular, por meio da criação de um quadro de especialistas ambientais nos órgãos federais competentes. A exigência de avaliação do impacto ambiental criou dinâmica institucional dentro das agências e imprimiu uma mudança de perspectivas, o que não implica que os dispositivos processuais sempre tiveram efeitos positivos significativos (TAYLOR, 1984).

A NEPA forneceu modelo de como as questões ambientais poderiam ser integradas no âmbito das políticas públicas, mas o desenvolvimento generalizado da idéia só passou a ser aplicado em outros países na década de 1980.

9 - Solução de problemas ambientais por meio do deslocamento das fronteiras política e administrativa.

A legislação de controle da poluição da década de 1970 permitiu que as soluções para problemas ambientais fossem encontradas, às vezes, além das fronteiras dos países. Um exemplo significativo foi a questão que envolvia as fábricas, geralmente localizadas próximas às fronteiras dos países e se constituíram em uma das principais causas de 
emissão de dióxido de enxofre de longo alcance, chegando até a ultrapassar as fronteiras dos países.

As chaminés dessas fábricas foram projetadas para reduzir o acúmulo de dióxido de enxofre nas vizinhanças por meio da emissão desses gases para a atmosfera. Em função da altura que eram lançados esses gases acabavam ultrapassando as fronteiras físicas dos países europeus. As soluções para esses problemas, muitas vezes, foram encontradas com auxílio de uma harmonização das legislações dos países envolvidos (WEALE, 1992).

Alguns países da Europa Ocidental se envolveram em atritos internacionais devido à poluição por dióxido de enxofre que era na realidade resultado da aplicação de medidas para solucionar os problemas locais. Nem todas as iniciativas políticas da década de 1970 ignoraram a dimensão internacional dos problemas de poluição e, em alguns casos foram os acordos internacionais que agiram em nível local.

A Convenção sobre a Poluição Marinha, em 1972, por exemplo, levou diversos países a tomar medidas para banir o lançamento de resíduos no mar. No entanto, foi possível permitir que os problemas nacionais fossem resolvidos à custa de gastos internacionais. Por outro lado, os problemas globais criados pela emissão doméstica de dióxido de carbono e responsáveis pelo efeito estufa, não receberam qualquer tipo de atenção.

Além disso, a diversificação dos problemas ambientais era muito significativa e mesmo que as estratégias de política de controle da poluição tivessem sido efetivas na resolução dos problemas para os quais foram elaboradas, não teriam sido capazes de lidar com o aumento da complexidade e da frequência dos problemas que surgiam.

\subsection{Os novos tipos de poluição e os primeiros esboços da nova política}

No final da década de 1980 era possível perceber as inúmeras deficiências apresentadas pela política ambiental elaborada na década de 1970, pois os problemas com a poluição não foram resolvidos ou se apresentavam em situação pior do que já estavam. Essas deficiências foram percebidas por meio das informações disponibilizadas por indicadores ambientais que mostraram um aumento generalizado da poluição e da deterioração da qualidade do meio ambiente.

As emissões de óxidos de nitrogênio, que contribuiam para o smog fotoquímico e para a chuva ácida, aumentaram em média 12\%, nos países da OCDE entre 1970 e 1987, com alguns países como Canadá, Holanda, Noruega e Portugal apresentando acréscimos percentuais muito acima da média global. Os resíduos urbanos, medidos em $\mathrm{Kg} /$ pessoa, aumentaram em média 26\% nos países da OCDE no período de 1970 a 1988, enquanto que o uso de fertilizantes nitrogenados aumentou $48 \%$ nesses mesmos países e $142 \%$ no mundo, no mesmo período (OCDE, 1997). 
Chamaram a atenção, no entanto e devido às possíveis implicações com as mudanças climáticas e o aquecimento global, o aumento de 15\% nas emissões de dióxido de carbono nos países da OCDE e o aumento de 43\% no mundo, no período de 1971 a 1988. Quatro países lideraram esse aumento: Austrália, Nova Zelândia, Espanha e Portugal. Os Estados Unidos, por sua vez, apresentaram um acréscimo em termos absolutos, significativo (OCDE, 1997).

Concomitantemente, com o aumento global nas emissões de gases, eram feitos investimentos sócio-econômicos significativos de longo prazo, que contribuiam para o aumento global da poluição. O crescimento da população mundial continuava a pressionar de forma significativa o abastecimento de alimentos disponíveis e estimulou os agricultores a aumentar a produtividade com a intensificação do uso de fertilizantes. O crescimento populacional também pressionava o uso dos mares e dos rios como receptores de esgoto e de outras formas de resíduos (WEALE, 1992).

O avanço dos indicadores da qualidade de vida viabilizou o aumento do consumo de mercadorias e consequentemente a disposição de resíduos sólidos no meio ambiente. $O$ desenvolvimento do setor de transportes demandou a construção de novas rodovias que registrou aumento de 83\% nos países da OCDE, no período de 1970 a 1988 (OCDE, 1997).

Os indicadores de qualidade ambiental revelaram os problemas criados por esses avanços. No período de 1970 a 1990, a concentração de derivados do nitrato aumentou em diversos rios, como: St Lawrence, Fraser, Mississipi, Loire, Rhône, Po, Tâmisa e o Mersey. No período de 1950 a 1980, as concentrações de ozônio na Antártica, foram reduzidas de forma constante e houve significativa contaminação microbiana dos mares pelo lançamento de esgoto e de outros resíduos (OCDE, 1997).

Bursztyn e Persegona (2008), afirmam que além desses indicadores ambientais negativos, uma série de acontecimentos demonstrou que a resposta política adotada na década de 1970 para os problemas da poluição, foi inadequada. Em 1986, o acidente na usina nuclear de Chernobyl, na Ucrânia, revelou as ineficiências de gestão no uso da energia nuclear. Em 1988, a proliferação de algas e mortes de focas no Mar do Norte foi outro alerta para os danos causados ao meio ambiente pela poluição e em 1989, o petroleiro Exxon Valdez provocou um grande acidente ambiental no litoral do Alasca, com um vazamento de petróleo no mar com danos irreversíveis para a fauna e a flora locais.

No verão de 1988, muitas cidades dos Estados Unidos registraram altos níveis de ozônio troposférico. Em Hong Kong, aumentaram os incidentes com as marés vermelhas enquanto que na Antártida o "buraco" na camada de ozônio também apresentou sensível aumento (WRI, 1990).

Apesar de o cenário global mostrar deterioração ambiental, os indicadores não foram todos negativos no período. A questão das emissões de dióxido de enxofre foi mantida na 
agenda política internacional pelos países escandinavos durante todo o período. Como resultado, em parte, pela pressão desses países e em parte, pelas mudanças de tecnologias envolvidas nos processos produtivos, as emissões de dióxido de enxofre foram reduzidas em 25\% nos países da OCDE, entre 1970 e o final da década de 1980 (OCDE, 1997).

Outro indicador positivo registrado no período foi a constatação de que a relação diretamente proporcional entre as emissões de dióxido de enxofre e o PIB foi desfeita. Ficou constatado que as quantidades emitidas de dióxido de enxofre no Canadá, EUA, Japão, França, Alemanha, Itália e Reino Unido, diminuíram concomitantemente com um aumento do PIB. Também, nos países da OCDE, houve declínio da concentração de partículas na atmosfera dos centros urbanos (OCDE, 1997).

O uso ineficiente da energia era a causa de muitos problemas de poluição ambiental, porém a intensidade de energia e o uso de recursos energéticos por unidade do PIB declinaram na maioria dos países da OCDE no período de 1970 a 1990. Aumentos foram registrados apenas na Espanha, em Portugal e na Turquia como resultado dos avanços da industrialização.

Isto não significou que os países desenvolvidos estivessem necessariamente utilizando menos energia per capta, mas mostrou que o uso da energia não estava aumentando na mesma proporção que o PIB. A relação entre o crescimento econômico e o aumento no consumo de energia estava sendo alterada.

No fim da década de 1980, apesar dos indicadores ambientais positivos, havia ampla percepção de que os problemas relacionados com a poluição ambiental estavam aumentando e tornando-se mais sérios e que as estratégias políticas adotadas até então, falharam em lidar adequadamente com esses problemas (WEALE, 1992).

No mesmo período, organizações de pesquisas públicas globais verificaram em 15 países diferentes que segundo suas populações, o meio ambiente tinha se tornado pior do que na década anterior. Conclui-se também que os problemas ambientais colocavam em risco não somente a saúde pública e a sobrevivência de muitas espécies de plantas e de animais, mas também comprometia o funcionamento dos ciclos vitais da natureza que são essenciais para a própria sobrevivência humana (WRI, 1990).

Essa percepção negativa de fracasso das políticas ambientais refletiam os resultados das abordagens políticas adotadas nas décadas anteriores. Apesar do estabelecimento e do fortalecimento de regimes de proteção ambiental nos âmbitos nacional e internacional na década de 1970, novos problemas ambientais emergiram na década de 1980. A poluição do meio ambiente por derivados de nitrato, o esgotamento da camada de ozônio e as mudanças climáticas globais eram tipos novos de poluição, não estavam previstos e eram questões que os processos políticos existentes não conseguiam solucionar (WEALE, 1992). 
Além disso, a adoção do princípio da atenção seletiva para subsidiar as abordagens políticas mostrou que problemas como a contaminação dos solos, não foram considerados no processo de elaboração das estratégias políticas anteriores. Com o desenvolvimento da instrumentalização científica e do conhecimento ambiental, a conscientização sobre a escala e a seriedade dos problemas ambientais também aumentou.

O aumento da conscientização, para Held (1991) foi acompanhada pelo aumento do conhecimento sobre as fontes de poluição ambiental e de seus impactos. A poluição ambiental foi entendida como resultado das atividades econômicas e principalmente como produto direto das abordagens políticas que os governos selecionavam para lidar com problemas como os subsídios econômicos dados aos agricultores e os incentivos dados para o setor de transportes para a construção de rodovias.

As fontes de poluição eram variadas e os impactos ambientais negativos eram difusos. A escala internacioal dos problemas da poluição trouxe desafios até então inéditos para as organizações internacionais como aqueles que ameaçavam a soberania dos países e exigiam a prática da cooperação ad-hoc para a solução de questões específicas.

As consequências econômicas negativas da permissão continuada da poluição ambiental também ficaram aparentes. Tolerar a poluição significou transferir o aumento com os custos para períodos posteriores (TAYLOR, 1984).

A proteção dos interesses das gerações futuras tornou-se questão central nas discussões internacionais, como ficou demonstrado na ocasião da elaboração do Relatório Brundtland. Essa postura tornou o controle da poluição uma questão de política pública e necessária para alterar a estrutura do processo político que abordava os problemas ambientais ocasionados pela poluição.

A resposta política elaborada na década 1970 começou a ser substituída por uma nova política que surgiu no início da década de 1980. Assim que esse processo de substituição começou, os principais pressupostos das estratégias de reforma da década de 1970 foram sendo abandonados, principalmente, aquele que afirmava que a proteção ambiental e o crescimento econômico não poderiam ser harmonizados, pois representavam um jogo de soma zero, no qual mais de um, necessariamente significava, menos do outro (HAJER, 1995).

A adoção desse pressuposto prejudicou a criação e a manutenção das instituições políticas para viabilizar a harmonização da proteção ambiental com o desenvolvimento econômico. Outro pressuposto substituído foi aquele que defendia a ação pública como uma questão essencialmente, de reforma mecânica, ao invés de reforma moral.

Nesse contexto, as autoridades públicas asseguravam as regras adequadas para o jogo econômico sem levar em consideração as atitudes dos jogadores. Em todas as 
democracias ocidentais na década de 1950, estabeleceu-se o pressuposto de que as questões éticas não deveriam ser permitidas em assuntos públicos.

Ao contrário da difusão do questionamento desse pressuposto, optou-se por sua incorporação implícita na abordagem política da década de 1970, fato que intensificou a deficiência para priorizar problemas de implementação e observância das leis. Tal pressuposto foi de alguma forma, compartilhado entre as coalisões políticas pró meio ambiente e as coalisões pró-viabilidade econômica. A diferença entre elas era que as coalisões pró-meio ambiente favoreciam a adoção da reforma mecânica enquanto que as coalisões pró-viabilidade econômica eram resistentes a esse tipo de reforma.

Os problemas com a poluição ambiental deveriam ser resolvidos por meio do uso de instrumentos de política já existentes e reforçados a partir de uma base incremental. Propor a redefinição da relação entre o Estado e a economia era inapropriado. Isto era claramente observado pelo uso das técnicas de comando e controle na regulamentação administrativa referente aos diversos problemas de poluição que foram identificados (WEALE, 1992).

Grande parte da evolução da política foi construída levando-se em consideração velhas práticas de regulamentação para problemas públicos que tinham surgido quando a poluição ambiental tinha caráter bastante diferente. Com exceção da técnica de avaliação de impactos ambientais, as estratégias regulatórias eram tradicionais no estilo e inovadoras no âmbito.

Ficou implícita que a máquina administrativa do Estado-nação não era a forma apropriada para lidar com os problemas centrais e advindos da poluição ambiental. O Tratado da Comunidade Econômica Européia, por exemplo, não incluiu cláusula específica para regulamentação ambiental na sua versão original. No início da década de 1970, a Comissão achou que tinha de estabelecer sua competência legal na questão, por meio da adoção de normas ambientais para o comércio internacional (HAJER, 1995).

Determinados assuntos externos à estrutura da Comunidade Européia eram abordados por meio de tratados internacionais que levavam em consideração a soberania independente do Estado-nação e que poderia ser limitada somente pelo consentimento voluntário. No entanto, a concepção de que os principais processos de controle da poluição ambiental deveriam ter uma forma transfronteiriça e criar padrões internacionais de mútua interdependência, precisou esperar pela chuva ácida, pelos problemas com a camada de ozônio e pelas mudanças climáticas globais.

A persistência e a intensificação dos velhos problemas de poluição ambiental e o aparecimento de novas questões ambientais providenciaram o momento para a emergência da nova política de poluição ambiental na década de 1980. A Nova política refletiu a nova escala de problemas incluindo sua dimensão internacional, novos padrões de interação dentro das comunidades políticas relevantes e novas concepções intelectuais e ideológicas 
de questões políticas. A nova política de poluição ambiental surgiu a partir da antiga política (WEALE, 1992).

A estratégia do controle de poluição da década de 1970 e os movimentos políticos que foram desenvolvidos deram início ao processo de criação do novo sistema de atores que elaboraram a nova política. Apesar de a regulamentação da poluição ambiental ter envolvido principalmente autoridades ligadas ao controle da poluição, indústrias reguladas e alguns poucos membros da legislatura; a comunidade política se expandiu e se diversificou refletindo tendências sociais mais gerais e marcou espaço para o controle da poluição na agenda política.

Na década de 1980, um número diversificado de atores passou a ter representação no processo, incluindo grupos de consumidores e organizações de interesse público. A Fundação Ford, por exemplo, desempenhou importante papel no início da década de 1970 financiando novas organizações de interesse público que foram capazes de utilizar o sistema legal para confrontar práticas predominantes na regulamentação de agroquímicos. Em outros países processos análogos estavam sendo desenvolvidos (WEALE, 1992).

Uma das razões pelas quais a comunidade política estava pronta para aumentar a incorporação de novos grupos ativistas pró-meio ambiente, foi a competência técnica demonstrada pelas novas organizações para desafiar as premissas da política e para explorar as oportunidades de estruturas políticas que foram abertas.

O movimento antinuclear das décadas de 1970 e 1980, para Ktschelt (1986), desempenhou papel importante nesse processo. Grupos ambientalistas eram tão competentes quanto os especialistas da burocracia da energia nuclear, para discutir temas como: dispositivos de segurança de reatores nucleares, efeitos da radiação na saúde humana, problemas da disposição do lixo nuclear e economia na geração de energia.

Além disso, todas as democracias liberais tinham dispositivos de ordenamento legislativo que permitiam ao público impugnar as decisões ligadas ao desenvolvimento de novas unidades de geração de energia. Variações na extensão e no caráter dessas estruturas de oportunidades políticas foram importantes no entendimento da variação do sucesso do movimento antinuclear.

A habilidade política dos grupos ambientalistas para alterar o caráter e 0 funcionamento da comunidade política, dependeu de determinadas mudanças sociais e econômicas. Grupos ambientalistas foram beneficiados pelo aumento dos níveis educacionais que imprimiu a melhoria do nível dos trabalhos prestados pelos ativistas e a melhoria do nível de informação do eleitor que se tornou cientificamente e socialmente alfabetizado.

A habilidade para desafiar as decisões políticas das elites existentes dependeu, em parte, da evidência de competência técnica. $O$ aumento dos níveis educacionais permitiu 
nova geração de simpatizantes capacitados para lidar com informações complexas. Ocorreu então, o aperfeiçoamento de jornalistas que se tornaram especialistas em questões de ciência e meio ambiente com habilidade para explicar questões técnicas de forma mais efetiva (YOUNG, 2000).

Os jornais designaram correspondentes especializados em meio ambiente que passaram a cobrir mais eventos ambientais e que contribuiu para aumentar a importância da questão ambiental nas agendas políticas. Isso fortaleceu um contexto no qual o ativismo ambiental tornou-se politicamente efetivo. Porém, as alianças políticas que se formaram ao redor dos interesses ambientais eram muito frágeis e as questões ambientais da década de 1970 eram dependentes de contextos políticos transitórios.

Os choques nos preços do petróleo nos anos de 1973, 1974 e 1979 fizeram com que considerações sobre o balanço de pagamento e sobre o crescimento econômico dos países dominassem o pensamento das elites políticas da época. Particularmente, sob a pressão desses reveses políticos, grupos pró-ambientalismo buscaram desenvolver e ampliar as iniciativas da década de 1970 sem, necessariamente, ser capazes de ir além dos termos de debate e das premissas intelectuais nas quais as iniciativas se baseavam.

Havia entre os pró-ambientalistas um novo sistema emergente de crença chamado de ME que desafiou o pressuposto fundamental sobre a impossibilidade de harmonização entre a preservação ambiental e o crescimento econômico. O argumento da ME não criou conflito com a priorização da preocupação com o meio ambiente e a economia e emergiu notoriamente no Relatório Brundtland, priorizando a proteção ambiental e a transformando como uma pré-condição para o desenvolvimento econômico de longo prazo (WEALE, 1992).

Sem a manutenção de meio ambiente saudável, a economia estaria ameaçada, particularmente porque os custos dos impactos ambientais expandiram e em parte porque a degradação ambiental ameaçaria os recursos físicos e sociais dos quais a prosperidade econômica dependeria (WCED, 1987).

Uma vez que a relação negativa entre o meio ambiente e a economia foi desafiada, outros elementos do novo sistema de crença começaram a ser desenvolvidos. A internalização das externalidades tornou-se questão de atitude, de finanças. A ruptura não se deu entre o setor privado e os ambientalistas, mas entre uma indústria progressiva e ambientalmente consciente e os tomadores de lucro de curto prazo (WEALE, 1992).

No âmbito das idéias da nova política, o comportamento dos consumidores tornou-se importante e o papel da política governamental não era mais somente satisfazer as necessidades e as preferências dos seus cidadãos. Era também fornecer apoio e incentivo para a adoção de comportamentos ambientalmente conscientes e que não ameassassem ou agridessem o meio ambiente. Uma vez que esse ponto de vista estabeleceu raízes, a 
linha entre a reforma mecânica da política de controle da poluição e a reforma moral foi cruzada.

O desafio da ME se estendeu, portanto, para além do ponto econômico. O meio ambiente saudável era condição necessária para a prosperidade de longo prazo e vinha corroborar com as mudanças ocorridas na relação entre o Estado, os cidadãos e as empresas privadas assim como as mudanças ocorridas nas relações entre os Estados.

Essa mudança de foco, para Hajer (1995), refletiu na mudança de padrões de agregação de interesse e de articulação de interesse. Onde antes era possível contrastar a coalisão da viabilidade econômica com a coalisão do meio ambiente limpo, a ME sugeriu um conjunto plural e diversificado de interesses com interpretações concorrentes e diferentes sobre quais valores estavam em jogo na questão da política ambiental.

Essas mudanças se ramificaram por meio da maneira pela qual a política ambiental foi percebida e elas incluíram mudanças nas estratégias de regulamentação, nos estilos emergentes da política pública, alterações nos padrões de relações internacionais, e mudança na relação entre ciência e política e entre competição ideológica e debate.

\subsection{Os primeiros posicionamentos para a mudança}

Importante destacar que as primeiras mudanças que foram propostas pela nova política da década de 1980 e que tinham o objetivo de substituir a antiga política de controle da poluição foi fruto de reflexões no âmbito da academia, do meio político, de agentes econômicos e notadamente de cientistas sociais, especificamente da sociologia ambiental. Três das principais obras que contribuíram para a elaboração dos pressupostos da ME foram criadas durante a década de 1970 e são descritas de forma consisa abaixo.

A primeira obra que realmente influenciou de forma efetiva as elites mundiais na década de 1970 foi Limits to Growth.

\subsubsection{Os Limites ao crescimento (The Limits to Growth)}

Em 1972, o Clube de Roma publicou seu primeiro relatório denominado os limites ao crescimento, elaborado por grupo de pesquisadores do Massachusetts Institute of Technology (MIT), liderado por Denis Meadows. O relatório apresentou cenários desafiadores para a sustentabilidade global, baseado em sistema dinâmico de modelagem computacional para simular as interações de cinco subsistemas econômicos globais: a população, a produção de alimentos, a produção industrial, a poluição e o consumo de recursos naturais não renováveis. 
O relatório alertava para o fato de que a humanidade enfrentaria obrigatoriamente, limites para o crescimento econômico com o modelo praticado, baseado no consumo exacerbado e altamente concentrado em poucas nações. Embora The Limits to Growth tenha sido severamente criticado, ele expôs pela primeira vez o conceito de limites externos, a idéia de que o desenvolvimento pode ser limitado pelo tamanho finito de recursos da Terra (BURSZTYN E PERSEGONA, 2008).

O crescimento exponencial contínuo causaria crise de recursos e escassez de alimentos, com o desaparecimento das reservas de recursos e com o aumento dos níveis da poluição. Combinou esta profecia da desgraça com uma chamada para a reforma radical do processo de tomada de decisão existente, com o objetivo de atingir o estado de equilíbrio global.

A obra foi criticada não só pelas falhas metodológicas e os pressupostos malthusianos insustentáveis, mas também pela sua agenda política implícita. A mensagem apocalíptica trazida pela obra não era nova. O estilo específico do relatório e o clima ideológico geral do início de 1970 deu à mensagem, ressonância política que atingiu um território político específico.

O fato de o relatório ter sido publicado pelo Clube de Roma contribuiu de forma significativa para que o mesmo fosse bem sucedido, já que o Clube era formado por proeminentes figuras do mundo dos negócios, por elaboradores de políticas e por representantes da ciência. Essas previsões apocalípticas não poderiam ser facilmente desacreditadas como mais um produto marginal dos ativistas antiprogresso da década anterior.

A iniciativa do Clube de Roma foi importante e Limites ao Crescimento foi o primeiro produto de seu projeto sobre o estado da humanidade. O objetivo do Clube de Roma era provocar um processo de mudança cognitiva global. Demonstrou clara afinidade com tentativas anteriores para tentar criar mudança no pensamento sobre o poder de déficit na política internacional. As estruturas existentes pareciam incapazes de responder aos desafios globais que o mundo industrial enfrentava (HELD, 1991).

Essa questão foi levantada mais explicitamente pelo Comitê de Cooperação Econômica do Atlântico no final de 1960, e recebeu atenção generalizada de atores poderosos do mundo das finanças, do comércio e da indústria. No entanto, os sistemas de valores de Limites ao Crescimento foram reforçados por algumas das características de seus autores.

O relatório foi escrito por especialistas conceituados do Massachusetts Institute of Technology (MIT), que eram cientistas líderes no campo promissor da cibernética. O grupo de especialistas liderados por Jay Forrester estava trabalhando no projeto de modelo de computador dinâmico que abarcaria todos os aspectos da realidade. 
Sob a liderança de Dennis Meadows este modelo Mundial foi elaborado com o objetivo de fornecer as respostas para as perguntas específicas propostas pelo projeto do Clube de Roma. A discussão trazida por Limites ao Crescimento foi reforçada pelo fato de que a teoria cibernética de sistemas tinha credibilidade nos círculos de tomada de decisões da época (HAJER, 1995).

Era uma oportunidade promissora para ampliar as possibilidades de tomar decisões de forma racional e científica em um momento em que a resposta à crescente complexidade das relações sociais tornou-se um tema predominante nos círculos governamentais. Esta combinação de mensagem apocalíptica, inserida em discurso cibernético muito respeitado e pronunciado por atores que não puderam ser imediatamente desacreditados, ajudou a explicar por que a mensagem de destruição ambiental, que foi apresentada em Limites ao Crescimento teve tal impacto sem precedentes sobre as opiniões da elite (WEALE, 1992).

A elaboração do relatório considerou a regulamentação da linguagem cibernética e tornou-se uma referência ideal para os Livros Brancos (Livros Governamentais) em um momento no qual o discurso foi visto por muitos como forma produtiva de pensar sobre questões complexas. De forma geral, Limites ao Crescimento foi exemplo de utilização extremamente bem sucedida do discurso como poder.

Apesar de seu status não oficial, a aura de respeitabilidade e conhecimento que acompanhava o relatório do Clube de Roma tornou-se referência fundamental no debate sobre as condições do meio ambiente. A ressonância alcançada pelo relatório significou que outros viessem para conceituar o problema ambiental de acordo com conceitos e categorias específicas.

Essa foi uma das intenções do Clube de Roma, pois o Relatório foi elaborado também para confrontar a sociedade sobre os possíveis efeitos da dependência contínua com as relações físicas, econômicas e sociais existentes no mundo: O Clube de Roma incessantemente enfatizou que a intenção do relatório era ser catalisador para a mudança (HAJER, 1995).

No entanto, sua profecia da desgraça também serviu para influenciar a direção que tomaria a reforma radical prescrita das instituições e dos processos políticos em todos os níveis. A este respeito, em um primeiro momento, parece surpreendente que a ênfase do relatório tenha sido no contorno dos problemas relacionados com o crescimento exponencial contínuo, apesar de argumentar que somente uma sociedade na condição de estado estacionário seria capaz de impedir o colapso global.

O Clube de Roma deixou implícito que era possível executar a tarefa de transformar a sociedade em estado constante de paz, de equilíbrio econômico e de equilíbrio ecológico. O relatório defendeu que a estratégia para harmonizar o desenvolvimento com o meio ambiente deveria ser concebida em conjunto, e sugeriu que os limites físicos ao crescimento 
fossem ainda mais reduzidos pelo político, pelo social, pelos constrangimentos institucionais, pela distribuição desigual da população e dos recursos e pela incapacidade de gerencia de grandes sistemas intrincados (HAJER, 1995).

$\mathrm{Na}$ condição de prática de poder discursivo, Limites ao Crescimento foi eficaz porque se concentrou na definição do problema e pela primeira vez retratou a questão ambiental como crise global. A construção do problema na condição de risco de colapso mundial orientou a busca de soluções. O modelo cibernético procurou colocar a ordem social e a ordem ecológica sujeitas à gestão de técnicas científicas.

Essas recomendações implícitas no Relatório do Clube de Roma ficaram um pouco mais explícitas em outro trabalho, menos influente, publicado pelo Clube de Roma em 1975. Trata-se da publicação "La Hunmanidad en la Encrucijada" de Merasovic e Pestel, que discutiu temas como: a reconciliação política global, mínimo de subsistência para toda a humanidade, plano de gestão de recursos do mundo, a ação cooperativa das multinacionais para estimular a industrialização, e o desenvolvimento da agricultura no terceiro mundo. 0 estudo priorizou a liberalização do comércio e a distribuição de recursos; rejeitou as idéias de autossuficiência e de estado estacionário e defendeu o crescimento orgânico.

No que diz respeito a Limites ao Crescimento pode-se afirmar que se tornou o catalisador de coalizão a partir do reconhecimento da gravidade do conflito ambiental, mas que procurou remediar a situação ambiental por meio de uma gestão mais organizada. $O$ meio ambiente corria perigo de se tornar questão de fuga, tanto socialmente quanto fisicamente, mas cuidadosamente planejado e com base nos mais recentes conhecimentos científicos, seria possível restaurar o seu equilíbrio.

A obra foi orientada para os líderes mundiais e as elites nacionais que esperavam se unir para uma abordagem conjunta do problema. Apesar da crítica acadêmica que se seguiu imediatamente a sua publicação, o relatório foi muito bem-sucedido nesse sentido. Outra obra que contribuiu para que as mudanças propostas na década de 1970 pudessem convergir para o que se chamou de ME foi Blueprint for Survival.

\subsubsection{Um modelo para a sobrevivência (Blueprint for Survival)}

A Blueprint for Survival (Um modelo para a sobrevivência) era um texto ambientalista e influente que chamou a atenção para a urgência e a magnitude dos problemas ambientais. Foi publicado em 1972 por um grupo constituído por mais de trinta dos mais importantes cientistas da época liderados por Edward Goldsmith e defendia a idéia de que o modelo de vida industrial do início da década de 1970 era insustentável.

Defendia uma sociedade radicalmente reestruturada como objetivo de evitar o colapso da sociedade e o rompimento irreversível dos sistemas de suporte à vida do 
planeta. Trazia diferentes idéias sobre a regulamentação da crise ambiental e sedimentou sua característica de urgência das mesmas extrapolações de crescimento exponencial do Massachussetts Institute of Technology (MIT) e também convocou a sociedade para o estado estacionário.

O autor defendeu a conversão da economia de fluxo em economia de estoque, com a minimização do uso de recursos não renováveis. Entre as suas proposições destacavamse muitas soluções tecnológicas como a introdução de esquemas de reciclagem, a conservação da energia, o imposto ecológico, a reorientação do transporte privado para o público, as novas práticas agrícolas ambientalmente saudáveis e a elaboração de nova forma de cálculo do PIB. Muitas dessas propostas tornaram-se elementos centrais da ME.

Era recomendado que, as pessoas vivessem em comunidades pequenas, descentralizadas e em grande parte desindustrializadas. As razões apontadas eram:

- Difícil aplicação do comportamento moral em uma grande comunidade;

- As práticas agrícolas e de negócios eram mais susceptíveis de ser ecologicamente corretas em comunidades menores;

- As pessoas se sentiriam mais satisfeitas em comunidades menores e;

- A redução da população reduz o impacto ambiental.

Os autores utilizaram sociedades tribais como modelo para o texto em função de características específicas como: eram pequenas comunidades em escala humana, tecnologias de baixo impacto, controles populacionais bem sucedidos, gestão sustentável de recursos, visões de mundo integradas holísticamente e ecologicamente, e um alto grau de coesão social como saúde física, bem-estar psicológico e realização espiritual dos seus membros.

Com relação à ordem, Limits to Growth, era muito diferente. Blueprint for survival forneceu um esboço completo de uma estratégia ambientalista que incluiu muito mais do que questões estritamente ambientais. A obra problematizou o modo de produção, as relações existentes entre o trabalho e o capital e a falta de moralidade da sociedade industrializada e urbanizada. No entanto, e de acordo com o autor, a diferença mais significativa foi que Blueprint for survival propôs a descentralização da sociedade industrial em unidades comunais menores e autossuficientes (HAJER, 1995).

O texto defendeu o desenvolvimento das comunidades econômicas relativamente fechadas e o uso de tecnologias intermediárias, ou seja, não intensivas em capital e em energia. Em muitos aspectos, essas propostas de nova ordem social, composta de conselhos de bairro e de trabalhadores de cooperativas, refletiram idéias anarquistas de autores como Peter Kropotin. Nesse ponto, a diferença com limites ao crescimento é muito grande (HAJER, 1995). 
The Limits to Growth defendeu maior integração e hierarquização para conter o problema (os problemas globais exigem soluções globais), enquanto Blueprint for survival defendeu a descentralização, a autossuficiência e o autogoverno. Limits to Growth acentuou a responsabilidade histórica das elites sociais, das empresas, da ciência e do governo, Blueprint for survival defendeu o autogoverno.

No geral, Blueprint for survival era uma crítica romântica e contraditória da sociedade moderna e defendia uma utopia descentralizada anti-tecnocrática, mas ao mesmo tempo se baseou em cibernética para ilustrar a urgência de seu apelo e contou com técnicas de planejamento abrangentes para viabilizar a nova utopia da autossuficiência.

Historicamente, Blueprint for survival e The Limits to Growth cumpriram papéis semelhantes para públicos diferentes. Blueprint for survival rapidamente tornou-se o corretivo mais radical de Limites ao Crescimento e enquanto Limites ao crescimento tipificou a resposta do aumento da importância das questões ambientais para o mundo dos negócios e para as elites governamentais, Blueprint for survival tornou-se uma referência para o público ambientalista radical de seu tempo. Apelou para a formação de um movimento para a sobrevivência das organizações de base e se ligou rapidamente à contribuição clássica de Fritz Shumacker, Small is beautiful, pequeno é bonito.

\subsubsection{Pequeno é bonito (Small is beautiful)}

Small is beautiful foi publicado pelo economista inglês Ernest Friedrich (Fritz) Schumacher, em 1973. A obra trouxe críticas das economias ocidentais e foi dirigida para um público mais amplo durante a crise de energia em 1973 e o surgimento da globalização. Argumenta que a economia moderna é insustentável e que os recursos naturais, como os combustíveis fósseis, são tratados como rendimentos dispensáveis quando na verdade deveriam ser tratados como capital, uma vez que não são renováveis e, portanto sujeitos ao esgotamento.

Defende a limitação da natureza para resistir à poluição e conclui que o esforço do governo deveria ser focado no desenvolvimento sustentável, pois apenas as transferências de tecnologias para países do Terceiro Mundo não resolverão os problemas ambientais subjacentes de uma economia insustentável.

A obra resgata o princípio da economia budista e serve de referência para movimento de reação contra o império das tecnologias sofisticadas e inacessíveis para as populações desfavorecidas.

O momento era propício às idéias voltadas para a busca da satisfação das necessidades humanas básicas por meio de práticas produtivas em escala humana. O pano de fundo foi a crítica às grandes corporações multinacionais que provocavam significativos 
impactos sociais e ambientais. A proposta de Shumacker era encontrar soluções simples para problemas elementares, como a fome, a saúde, o saneamento e a habitação (BURSZTIN E PERSEGONA, 2008).

Schumaker (1979) criticou o materialismo ocidental, questionou a definição ocidental de progresso, e defendeu a economia de permanência, a reavaliação dos valores humanistas no cristianismo e as tradições não ocidentais como o budismo e outras religiões orientais. De acordo com o autor, na empolgação sobre o desdobramento de seus poderes científicos e técnicos, o homem moderno construiu um sistema de produção que depreda a natureza e um tipo de sociedade que prejudica o homem.

O autor tentou descrever uma alternativa viável na qual um novo senso de comunidade moral se reconciliava com os avanços tecnológicos. Defendeu unidades de trabalho de pequena escala baseadas na tecnologia intermediária e que foram harmoniozamente projetadas com base na compreensão das leis da ecologia.

As máquinas de Schumaker serviriam as pessoas e não seria necessário um sistema de especialistas para operá-las. O pequeno é bonito foi, uma crítica à economia ocidental e ao pensamento de grande escala. Alertou contra a continuação das práticas existentes, mas suas soluções contrastaram fortemente com as abordagens tradicionais de Limites ao crescimento. Além disso, Schumaker advertiu sobre as falhas da previsão, da construção de modelos e do planejamento detalhado, explicitamente usando Limites ao crescimento como exemplo (HAJER, 1995).

A obra argumentava contra o discurso de crescimento voltado para o desenvolvimento tecnológico e defendia o crescimento voltado para as necessidades reais do homem, para o tamanho real do homem. O Homem é pequeno e, então, o pequeno é bonito. A defesa do gigantismo é a defesa da autodestruição e o custo da sobrevivência é alto.

Além das novas idéias e posicionamentos que surgiam na academia e da persistência e da intensificação dos velhos problemas ambientais ocasionados pela poluição e que comprovavam a ineficiência das políticas ambientais adotadas, era possível constatar que mudanças significativas ocorriam no interior do movimento ambientalista. A nova política emergia também, em função dessas mudanças.

\subsection{Mudanças no movimento ambientalista}

Podem ser identificadas, pelo menos quatro razões, para explicar as mudanças que ocorreram no movimento ambientalista nas últimas décadas do século passado (HAJER, 1995). A primeira delas foi o fato de o ambientalismo radical ter sido sufocado pela recessão econômica do final dos anos 1970. Em face das dificuldades econômicas as questões 
ambientais foram substituídas por questões relacionadas com a inflação e o desemprego em massa. A insegurança econômica das sociedades nacionais frustrou a validade do discurso do crescimento seletivo.

O ambientalismo precisou encontrar novas formas de conciliar a reestruturação econômica com a proteção do meio ambiente para manter a credibilidade do seu discurso socio-ambiental. No âmbito do discurso político radical o argumento poderia ter sido culpar as mesmas práticas rotineiras, tanto para os problemas ambientais quanto para os problemas econômicos.

A segunda razão foi a ocorrência de significativas mudanças no núcleo do movimento ambientalista. A profissionalização do movimento prejudicou a sua identidade e favoreceu a adoção de um modelo estratégico. Houve um aumento efetivo da consciência nas Organizações não Governamentais (ONGs) e nas elites, de que o estilo radical de confronto adotado até então, limitou desnecessariamente o avanço do movimento ambientalista como força social. A prática de manifestações de massa foi reconhecida como inadequada e as ONGs começaram a pensar em alternativas.

A terceira razão foi o aparecimento de outras questões ambientais como a chuva ácida ou a diminuição da camada de ozônio, que não eram tão conhecidas politicamente como o uso da energia nuclear, mas que pareciam ser base promissora para nova extensão da influência social do movimento ambientalista.

As campanhas estratégicas que haviam sido adotadas por ONGs como: Amigos da Terra e Sierra Club exploravam a importância das questões emblemáticas para que o público em geral pudesse compreender os problemas ambientais. Tal prática precisou ser modificada e passou da ênfase na natureza injusta do sistema em geral, para a ênfase nas graves ameaças que as práticas industriais representavam para a sociedade como um todo (WEALE, 1992).

A quarta razão, foi a disponibilidade política de um novo discurso alternativo. As Idéias de uma nova política tinham superado a fase inicial de elaboração e os trabalhos nos círculos acadêmicos e em outras organizações especializadas forneciam uma linguagem conceitual alternativa e sugeriam soluções concretas e a superação pragmática de problemas ambientais.

Eram propostas soluções para muitos dos problemas relacionados com a proteção ambiental. Durante a década de 1970, a política ambiental não tinha sido feita apenas nas ruas, mas também no domínio das instituições de formulação de políticas e de grupos de reflexão, embora de forma menos perceptível. A elaboração desse novo discurso ambiental nasceu durante a primeira fase de turbulência política provocada pela elaboração de Limites ao Crescimento (ANON, 1980). 
A partir desse momento, os formuladores de política e especialistas ambientais realizaram diversas conferências sobre o meio ambiente e produziram um fluxo significativo de informações com o objetivo de encontrar formas eficazes de regular os problemas ambientais. Levou-se em consideração muita pesquisa feita anteriormente como os trabalhos de Pigou $^{1}$ na economia, que chamaram a atenção para os custos sociais dos empreendimentos privados.

Tais questionamentos surgiram na década de 1920, foram retomados em 1950 e eram agora, discutidos junto aos círculos políticos por meio das atividades de instituições mediadoras como a OCDE, o PNUMA, e a Comissão Econômica para a Europa, das Nações Unidas (UNECE), que haviam criado seus próprios departamentos ou comitês de meio ambiente, ainda no início da década de 1970 (HAJER, 1995).

Importante enfatizar que essas instituições tornaram-se ativamente envolvidas na reflexão e nas pesquisas sobre os problemas ambientais e na elaboração de novo design para os instrumentos de política. A partir do final dos anos 1970 começaram a produzir evidências sobre os resultados altamente insatisfatórios das primeiras respostas legais dadas pelos governos, em relação ao desafio ambiental que foi proposto em anos anteriores.

O trabalho passou a ser desconstruir efetivamente a legitimidade das políticas governamentais nacionais vigentes. Relatórios elaborados pelo Departamento de Meio Ambiente da OCDE, pelo PNUMA e por organizações similares, mostravam os efeitos prejudicias à saúde humana em função da emissão de substâncias tóxicas pelas indústrias.

O trabalho dessas instituições, segundo Weale (1992), resultou na formulação de uma política ambiental alternativa e coerente que prometia ser eficaz e eficiente. Essas instituições enfatizavam a prática de novas estratégias para a formulação de políticas que priorizavam o princípio da precaução e a consideração efetiva das questões ambientais nos processos de decisão econômicos.

\subsection{Mudanças no discurso ambiental}

Podem ser identificados pelo menos, três momentos diferentes, para Hajer (1995), ao longo dos quais ocorreu um novo reposicionamento no discurso ambiental da década de 1970. Esses discursos facilitaram a formação da coalizão discursiva nacional em torno das idéias da ME que seriam fortalecidas na década seguinte. Destacam-se as forças políticas

\footnotetext{
${ }^{1}$ Economista inglês que desenvolveu o conceito de taxa de Pigou, uma medida do Estado para influenciar o comportamento dos agentes econômicos no mercado, com o objetivo de corrigir externalidades negativas. Além do mais formulou o efeito Pigou, que explica o aumento da demanda para bens de consumo num período de defação.
} 
que mediaram discussões sobre conceitos como: sustentabilidade, precaução, eficiência e auto-regulação.

O primeiro momento se deu com a publicação da Estratégia Mundial para a Conservação (World Conservation Strategy - WCS) em 1980, que significou a emergência de uma coalisão de políticas de meio ambiente orientadas para a elaboração de políticas direcionadas para o alcance do desenvolvimento sustentável.

A referida publicação foi elaborada conjuntamente pelas ONGs moderadas: União Internacional para a Conservação da Natureza (IUCN) e World Wildlife Fund (WWF) e pelo (PNUMA), e foi escrita em colaboração com a Organização das Nações Unidas para a Alimentação e a Agricultura (FAO) e a Organização das Nações Unidas para a Educação, a Ciência e a Cultura (UNESCO).

O objetivo do relatório foi harmonizar o desenvolvimento socio-econômico com a conservação do meio ambiente e enfatizar a necessidade de preservação dos ecossistemas naturais. Enfatizava basicamente as mesmas linhas do ecodesenvolvimento, lançadas na Conferência de Founex, em 1971, mas com mais ênfase na preservação da biodiversidade (IUCN, 1997).

A Conferência de Founex, na Suíça foi preparada para reparar as diferenças e diminuir a divisão entre os pontos de vista dos países desenvolvidos e em desenvolvimento. O Relatório Founex, de junho de 1971, identificou o desenvolvimento e o meio ambiente como "dois lados da mesma moeda".

As referidas organizações já pesquisavam, de forma ampla, os habitats em extinção e os ecossistemas. Argumentavam na direção de uma estratégia de desenvolvimento sustentável com base na utilização eficiente dos recursos e do planejamento ambiental e estabeleciam uma agenda de promoção da conservação da natureza com a elaboração de diversas sugestões de políticas ambientais.

Para a Comissão Econômica para a América Latina (CEPAL), a Estratégia Mundial para a Conservação teve pequena repercussão na América Latina, principalmente por ter priorizado a conservação dos recursos naturais em detrimento da gestão desses recursos para o alcance do desenvolvimento sustentável.

A reconceitualização de novas orientações para políticas ambientais foi recebida de forma favorável e significou uma mudança no domínio ambiental. A orientação política do WCS enfaticamente, se diferenciou da ação ambiental típica de confronto utilizada até então, nas campanhas contrárias ao uso da energia nuclear.

Concomitante com a luta das partes antagônicas do uso da energia nuclear surgia novo discurso de coalizão no domínio ambiental, composto por forças moderadas que elaborava um discurso com a inclusão das organizações supranacionais, os quangos e as organizações não governamentais. A WCS foi ponto focal para coalizão de um discurso que 
efetivamente começou a explorar o meio termo que não existiu durante o auge da polêmica nuclear (ANON, 1980).

O sucesso da WCS mostrou o potencial político que existia para um argumento ambientalmente saudável e elaborado de forma razoável. A recepção favorável da referida publicação que talvez não pudesse ser explicada sem a existência do movimento ambiental radical, contribuiu efetivamente para o aumento da insatisfação relacionada com a falta de resultados dentro do movimento ambientalista radical. Ao mesmo tempo, ofereceu posicionamentos alternativos para os ambientalistas e os governos.

O segundo momento que contribuiu para o reposicionamento do discurso ambiental envolveu as atividades da OCDE. A Comissão de Meio Ambiente da OCDE, lançada em 1970, funcionou como um think-tank e mediadora de idéias que surgiram no meio acadêmico. A ideia principal defendida pela OCDE foi que os problemas referentes à poluição eram decorrentes de ineficiência e os custos deviam ser pagos pelos poluidores, de acordo com o princípio do poluidor pagador.

$\mathrm{Na}$ condição de organização essencialmente econômica, a OCDE deu ênfase na relação entre a economia e o meio ambiente durante a reunião de ministros do meio ambiente dos países membros, em maio de 1979. A declaração oficial sobre medidas preventivas não acrescentou muito além de propor que critérios ambientais fossem considerados no processo de tomada de decisão e sugerir a utilização de instrumentos econômicos e fiscais em detrimento de instrumentos normativos legais (OCDE, 1985).

A imprensa enfatizou os argumentos subjacentes que foram importantes na tentativa da OCDE de dar origem a ME. A mudança de orientação na economia teria de levar em consideração a complementariedade e a compatibilidade entre as políticas ambientais e econômicas. O formato do jogo de soma positiva, que se tornou pressuposto da ME nasceu por necessidade na OCDE (HAJER, 1995).

A política ambiental foi pensada como não contraditória à política econômica e considerada como um instrumento potencial para a recuperação econômica. O impacto das políticas ambientais sobre a produtividade e sobre a rentabilidade foi importante em um período em que os investimentos e a produtividade eram cruciais para o alcance de taxas aceitáveis de crescimento econômico. Os possíveis impactos das políticas ambientais sobre a inflação, sobre o emprego e sobre o balanço de pagamentos dos países, deveriam ser considerados na elabração das políticas.

A OCDE chamou a atenção dos governos para a ME, destacando seu potencial em relação ao crescimento econômico e enfatizando a necessidade de adoção de abordagem integrada que incluísse políticas referentes ao uso da terra, à energia, aos transportes e ao turismo, sem as quais as políticas preventivas não seriam bem sucedidas (OCDE, 1985). 
A necessidade de mudança no discurso da política foi reforçada pela OCDE, em 1979, que mostrou como muitos combustíveis e materiais tornariam-se escassos se nenhuma mudança estrutural fosse feita no sistema produtivo. A contribuição da OCDE para a promoção da ME culminou com a Conferência Internacional sobre Meio Ambiente e Economia, em Junho de 1984.

$\mathrm{Na}$ conferência, especialistas ambientais de vários países reuniram-se com os governos para discutir temas desafiadores para a ME como: os benefícios das políticas ambientais, meio ambiente e inovação industrial, a eficácia e a eficiência nos cuidados ambientais e o papel dos instrumentos econômicos. A principal conclusão da conferência foi que o meio ambiente e a economia, se fossem bem geridos, reforçariam-se mutuamente, apoiariam-se e seriam impulsionados pela inovação tecnológica (OCDE, 1985).

O terceiro momento que provocou reflexão sobre a redefinição do discurso ambiental ocorreu com os debates no âmbito das Comissões das Nações Unidas sobre Desenvolvimento, Segurança e Meio Ambiente. O Relatório Brundtland, Nosso Futuro Comum, de 1987, deve ser visto como continuação dos relatórios: Relatório Brandt NorteSul: Um Programa para a Sobrevivência, de 1980, Crise Comum, de 1983 e do relatório de Segurança Comum, de 1982, da Comissão Palme (EKINS, 1992).

Essa sequência de relatórios da ONU priorizou a necessidade de maior cooperação multilateral entre os países e foi fortemente inspirada pelas idéias social-democratas da Europa Ocidental. Da mesma forma, a OCDE, ressaltou a necessidade de olhar para as questões econômicas e ambientais como essencialmente interligadas.

No entanto, desta vez, o pano de fundo da ligação entre as questões ambientais e as questões econômicas do desenvolvimento não estava ligado às preocupações com a eficiência, mas partia da experiência social-democrata deste tipo particular de trabalho das Nações Unidas.

As comissões da ONU problematizaram as dificuldades originadas no boom do pósguerra em relação à produção e ao bem-estar ocidental e tentou manter, ou mesmo elaborar um discurso de problemas globais compartilhados sob a perspectiva da solidariedade. Tal discurso representava uma tradição social-democrata orientada pelo Estado delineado pelos economistas keynesianos social-democratas, como Galbraith e Tinbergen (HAJER, 1995).

A Comissão Mundial sobre Meio Ambiente e Desenvolvimento (WCED), adotou um tom crítico e seu objetivo era colocar as questões ambientais no núcleo das discussões da política com ênfase na economia. Da mesma forma, visou resistir à dicotomia entre o meio ambiente e o desenvolvimento, que havia dividido o Norte e o Sul na Conferência de Estocolmo em 1972. Além disso, a WCED não acreditava em soluções criadas pelo livre mercado, e considerava que a abordagem de planejamento global pudesse conter 0 funcionamento do livre mercado (REDCLIFT, 1987). 
Os três momentos acima analisados impulsionaram a ME e a definiram como sendo o produto da coalizão de forças de atores específicos que defendiam seus próprios interesses e orientações e se identificavam por meio de um vocabulário comum e de uma forma comum de enquadrar a problemática ambiental.

Dessa forma, o novo discurso político-ambiental adotado por organizações como a OCDE, pelo PNUMA e por ONGs moderadas como a WCS, IUCN e WWF, além da persistência dos problemas ambientais que não foram resolvidos pelas políticas ambientais da década de 1970 foram importantes propulsores para que surgisse no início da década de 1980 um novo discurso político denominado ME.

Muitas das idéias que construíram a nova política foram discutidas em diferentes lugares e diferentes fóruns desde meados dos anos 1960. Até meados dos anos 1980, o discurso eco-modernista não representou uma força que pudesse efetivamente desafiar o conceito predominante de problemas ambientais como problemas incidentais que requer soluções ad hoc. Contudo, a partir de meados dos anos 1980, as falhas de regulamentações foram sendo reconhecidas e aceitas pelos atores da política ambiental.

A maioria dos países, com poucas exceções, não admitiam que a problemática ambiental exigisse mudança fundamental no estilo e no processo de elaboração de políticas. No entanto, a partir de meados dos anos 1980, a ME rapidamente conquistou o espaço discursivo no âmbito ambiental e passou a ser vista como a forma mais legítima de conceituar e discutir o ambiente como problema de decisão política (HAJER, 1995). 


\section{Capítulo 2 - A EMERGÊNCIA DA MODERNIZAÇÃO ECOLÓGICA}

\subsection{Introdução}

O objetivo desse capítulo é apresentar um quadro conceitual que permita apresentar a Modernização Ecológica (ME). Do ponto de vista teórico, esse capítulo propõe uma abordagem ampla para a integração das diferentes definições de ME e do ponto de vista prático, é usada como uma referência para o estudo empírico sobre a aplicação da ME no setor de papel e celulose do Brasil.

Nessa pesquisa, admite-se que a definição de ME está relacionada com o papel central da inovação tecnológica e induzida ambientalmente nos processos produtivos com o objetivo de produzir simultaneamente melhoria no desempenho ambiental e aumento da competitividade dos produtos das empresas.

Torna-se necessário desenvolver uma abordagem mais específica, pois as definições atuais são bastante gerais e dificultam uma avaliação empírica e efetiva sobre a aplicação da ME. É possível desenvolver uma abordagem que adota um conceito estreito de ME e que ao mesmo tempo abarca as diversas perspectivas existentes da referida Teoria. A ênfase que é dada nessa tese relaciona-se com a ME baseada na inovação tecnológica ambiental.

Esse capítulo apresenta o quadro conceitual considerando cinco itens principais. No primeiro item são descritas as primeiras idéias sobre a ME e são apresentados os principais pressupostos da teoria. No segundo item são apresentadas algumas abordagens da ME enquanto que no item terceiro é apresentada a abordagem da ME baseada na inovação tecnológica ambiental que subsidiou o estudo empírico dessa pesquisa. No item quarto é feita uma breve análise sobre a importância da avaliação da ME.

\subsection{Apresentação das características e dos pressupostos básicos da ME.}

Os primeiros trabalhos acadêmicos sobre a ME foram elaborados pelo sociólogo alemão Joseph Huber, na primeira metade da década de 1980 quando afirmou que o principal problema das sociedades industriais contemporâneas estava relacionado com a colonização da "sócio- esfera" e da "eco-esfera" pela "tecno-esfera" (HUBER, 1986).

Considerou que os referidos problemas eram erros ou falhas da estrutura do sistema industrial e sugeriu que poderiam ser superados por meio da reestruturação eco-social das instituições básicas do tecno-sistema.

A ideia era definir uma harmonização entre a economia e a ecologia e identificar uma direção para uma modernização dos países industrializados com economias de mercado 
desenvolvidas que priorizasse iniciativas preventivas ambientalmente amigáveis e de longo prazo, por meio da inovação em tecnologias ambientais.

A inovação tecnológica e induzida ambientalmente era considerada a força motriz do desenvolvimento industrial contínuo para superar as crises ecológicas no mundo desenvolvido. Ao contrário de teóricos de outras escolas que consideravam o desenvolvimento ecológico como a causa da crise ambiental e sugeriam a desindustrialização ou o abandono do sistema capitalista, a ME argumentava que os problemas ambientais poderiam ser resolvidos pelo aprofundamento do progresso, por uma "hiper-industrialização" (HUBER, 1986).

O conceito foi desenvolvido na "Escola de Berlim" por um grupo de cientistas sociais com destaque para Martin Jänicke e que desenvolviam projeto de modernização demandado pelo governo Alemão. Posteriormente, a idéia influenciou o debate ambiental na Alemanha e chegou até os círculos da socialdemocracia e ao partido verde.

Enquanto Huber estimulava o discurso científico social, Janicke, por sua vez, influenciava o debate político alemão. Ambos os pesquisadores defendiam um projeto estratégico baseado na tecnologia e orientado pela inovação, com priorização do uso eficiente de recursos, com o objetivo de alcançar simultaneamente benefícios ambientais e econômicos.

Apesar da emergência da ME na década de 1980, alguns países como o Japão, já trabalhavam desde a década anterior, com algumas idéias que posteriormente influenciaram a ME. O Ministério da Economia, Comércio e Indústria do Japão (METI) desenvolveu em 1974, o conceito de economia intensiva com o objetivo de promover a sustentabilidade e a inovação para reduzir a dependência do país em relação às importações de recursos naturais. Esse conceito influenciou o debate na Alemanha sobre inovação que teria forte impacto na definição de ME (KNEESE e SCHULZE, 1985).

De acordo com Mol e Spaaargaren (2000), na fase inicial da ME, os pesquisadores desenvolveram um arcabouço teórico, sustentado em pesquisas empíricas localizadas em países europeus específicos e pertencentes à OCDE, mostrando a relevância das inovações tecnológicas induzidas ambientalmente e o seu impacto para a emancipação (relativa) da ecologia por meio da construção de racionalidade e de interesses próprios.

Destacaram-se nessa fase os estudos de Joseph Huber e as principais características foram:

- Ênfase no papel das inovações tecnológicas, na reforma ambiental, especialmente na esfera da produção industrial;

- Atitude crítica em relação ao Estado burocrático;

- Atitude favorável em relação ao papel da dinâmica e dos atores de mercado nas reformas ambientais; 
- Perspectiva teórica de sistemas, em vez de evolucionária, com noção limitada de agência humana e entraves sociais e;

- Orientação para análise no nível do Estado nação.

A segunda fase ocorreu entre o fim da década de 1980 e a primeira metade da década de 1990 e seus principais expoentes foram Weale e Jänicke. Suas principais características foram:

- Ênfase menor na inovação tecnológica como o motor da modernização tecnológica;

- Visão mais equilibrada sobre os respectivos papéis do Estado e do mercado na transformação ecológica;

- Atenção maior na dinâmica institucional e cultural da ME e;

- Estudos comparativos da produção industrial nos países da OCDE.

Nessa fase, o debate político avançou para alguns fóruns específicos como a Comissão para o Meio Ambiente da OCDE, o PNUMA e algumas ONGs moderadas como a IUCN e o foco era considerar as agências governamentais como forças propulsoras da ME. De acordo com Milanez (2009), foi proposto nessa fase, que a coordenação de políticas públicas poderia contribuir para um desenvolvimento industrial solidamente ecológico. Foram apresentadas ainda, explicações adicionais sobre como o mercado e a "ecologização" do consumo poderiam motivar mudanças nos sistemas de produção.

A terceira fase ocorreu a partir da metade da década de 1990 e suas principais características foram:

- A fronteira da teoria da ME foi ampliada teoricamente e geograficamente para incluir estudos sobre a transformação ecológica do consumo;

- Aplicação da ME em países que não pertencem à União Europeia, em países industrializados e desenvolvidos da OCDE, inclusive nos Estados Unidos e no Canadá, além das economias em transição da própria União Europeia e;

- Consideração de processos globais.

$\mathrm{Na}$ fase atual, os estudos têm se preocupado com perspectivas comparativas, incluindo, mas não se limitando, às formas nas quais os processos de globalização podem catalisar os processos de ME nos países do Hemisfério Sul.

A partir dessa fase, com a intensificação das publicações sobre o tema, a ampliação do número de pesquisadores e a adoção de diferentes objetos de pesquisa, a ME passou a receber maior atenção e ampliar o seu debate com outras ciências sociais, notadamente com as ciências políticas e a economia.

Pode-se dizer que o seu crescimento como conceito foi beneficiado pela efetividade na resposta oferecida para uma variedade de circunstâncias ou imperativos relacionados 
com o pensamento sócio-ecológico da década de 1990. Com o crescimento e o amadurecimento do conceito, aumentaram também as diferentes interpretações e disputas entre pesquisadores que contribuíram para o avanço de perspectivas conflitantes nos estudos de processos de ME.

No discurso ecomodernista a poluição ambiental é considerada um problema de ineficiência e a inovação deve orientar os processos produtivos e de distribuição por meio da criação de tecnologias limpas. Nesse sentido a ME é orientada pelas forças que Schumpter (1985), identificou como produtoras do impulso fundamental que estabelece e sustenta o motor do capitalismo em movimento.

Mol e Janicke (2010) argumentam que a ME define um estilo de discurso político que reforça a gestão ambiental efetiva e que está incluído em um novo sistema de crenças. Para que esse discurso político alcance seus objetivos, Christof (2010) propõe uma ligação mais estreita entre a ME e a modernização política sugerindo novas formas de intervenção políticas.

Além desse aspecto político, a ME atribui um papel de destaque para a ciência e a tecnologia modernas, no processo de reforma ecológica e propõe a "ecologização" da economia como um dos caminhos para superar a crise ambiental. Tal processo de reforma deve ser orientado pelas dinâmicas econômicas e de mercado nas quais as empresas inovadoras e outros agentes econômicos têm papel central na elaboração de políticas públicas de meio ambiente.

Nos processos de reforma ecológica, no que diz respeito ao papel do Estado, além de uma transferência de responsabilidades para o âmbito do mercado, a ME afirma que é necessário que ocorra um deslocamento de:

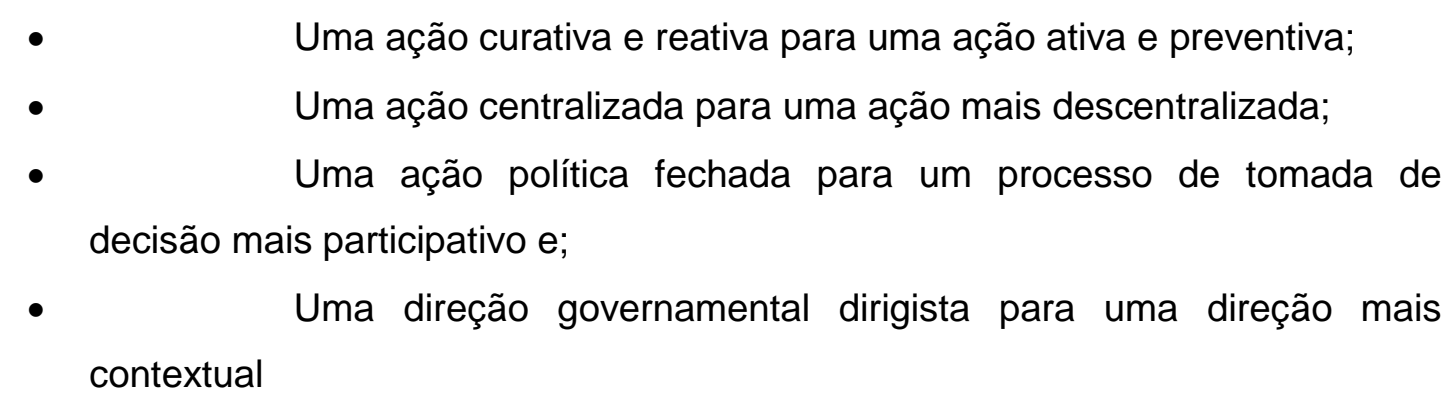

Ao contrário do que era defendido na década de 1970, a ME sugere a interdependência harmoniosa entre o desenvolvimento econômico e a proteção ambiental já que as instituições e os mecanismos modernos de mercado da economia podem ser reformados e assim, adotar critérios ecológicos, além dos econômicos para orientar os processos de produção e de consumo. O status da economia e da ecologia seriam correspondentes e emancipados ("economização" da ecologia).

A ME não interpreta essa emancipação como um processo de hegemonia da racionalidade ecológica sobre a racionalidade econômica, mas percebe que as duas 
racionalidades têm cada uma o seu lugar e legitimidade próprios, relativamente independente uma da outra e dirigida a difentes fins. Dessa forma, as práticas de produção e de consumo deverão ser concebidas e avaliadas, de acordo com as duas racionalidades (OLIVIERI, 2009).

Apesar da desconexão entre as perspectivas da ME e das disputas internas entre as diferentes escolas, o conceito manteve certo nível de coerência. A literatura em geral, prioriza as discussões sobre as relações entre o meio ambiente, a economia, a sociedade e a política pública que imprimem uma iden tidade comum para os estudos sobre a ME.

\subsection{Pressupostos teóricos da ME}

Desde meados da década de 1980 investiga-se a compatibilidade entre os pressupostos conceituais e as evidências empíricas da ME nas sociedades modernas. Alguns desses pressupostos e que estão relacionados com os desenvolvimentos institucionais observados nas últimas décadas, segundo Olivieri (2009) são;

1) A criação, o desempenho e a avaliação dos processos de produção e de consumo estão baseados em critérios ecológicos, além dos critérios econômicos;

2) A ciência e a tecnologia modernas exercem um papel fundamental nessas transformações induzidas pela ecologia. Essas transformações não estão limitadas à introdução de tecnologias ad hoc ou adaptações integradas de processos, mas também incluem mudanças nas cadeias produtivas e de produtos, nos sistemas técnicos e nos setores econômicos envolvidos;

3) Os atores econômicos privados e os mecanismos econômicos e de mercado exercem um papel muito importante nos processos de reestruturação ecológica, enquanto que o papel tradicional das agências estatais muda de uma direção burocrática, de comando e controle, de cima para baixo, para uma "construção de normativas negociadas" (negociated rulemaking), criando condições favoráveis para co-direcionar esses processos;

4) As ONGs modificam gradualmente sua ideologia e expandem sua estratégia tradicional de colocar a problemática do meio ambiente nas agendas públicas e política para uma participação ativa de negociações diretas comos agentes econômicos e representantes do Estado, estreitamente vinculadas com os centros onde se produzem os processos de tomada de decisão, e para o desenvolvimento de propsotas concretas visando a reforma ambiental;

5) Esses processos de re-estruturação ecológica estão se desenvolvendo num contexto de maior independência gerada pelos processos de globalização em curso, especialmente nas suas dimensões política e econômica, e, portanto, não ficam confinado 
apenas dentro das fronteiras de um único Estado-nação, nem somente nos países desenvolvidos e;

6) As iniciativas e alternativas de desindustrialização para limitar a deterioração ambiental são aplicadas somente com um alcance marginal, devido, entre outros fatores, a sua limitada viabilidade econômica, e a seu escasso suporte ideológico e político, em condições de globalização.

As diferentes interpretações sobre a ME viabilizam também a identificação de diferentes pressupostos que estão presentes na maioria dos estudos sobre o tema. Para Milanez (2006), as principais suposições são:

1) Participação direta e cooperação das partes interessadas no processo de tomada de decisão.

As suposições sobre participação feitas pela ME destacam que os diversos grupos de interesse devem participar diretamente dos processos decisórios tanto no âmbito público quanto no âmbito privado. O novo papel do Estado prevê um processo de elaboração política mais descentralizado e participativo, inclusive com o deslocamento de algumas tarefas e responsabilidades específicas necessárias para a reestruturação ambiental para os agentes de mercado e/ou para as ONGs.

Por sua vez, as ONGs ambientalistas modificam gradualmente sua ideologia e expandem sua estratégia tradicional de fixar a problemática ambiental nas agendas públicas e política para uma participação ativa de negociações diretas com os agentes econômicos e representantes do Estado, com o objetivo do alcance de propostas concretas visando à reforma ambiental.

2) O alcance simultâneo de metas econômicas e ambientais

Uma das idéias centrais da ME defende que o desenvolvimento industrial contínuo e orientado pela inovação tecnológica representa a melhor opção para superar a crise ambiental do mundo desenvolvido.

Diferentemente de outras escolas de pensamento que defendem a desindustrisalização ou a substituição do sistema capitalista e que avaliam o desenvolvimento tecnológico como senso problemático, os estudos da ME argumentam que os problemas ambientais podem ser superados por meio de avanços tecnológicos e de uma Hiper-industrialização (HUBER, 1986; MOL, 1995). O uso de inovações tecnológicas orientadas ambientalmente é um dos instrumentos para a viabilização de um jogo de soma positiva (Win-Win) entre a economia e a ecologia.

3) Papel central da Ciência e da Tecnologia

Os estudos da ME enfatizam que a ciência e a tecnologia são centrais no processo de "ecologização" da economia e afirma que a trajetória atual dessas instituições está sendo modificada progressivamente pelo impacto da modernidade reflexiva e da crise ambiental. 
A mudança no papel da ciência e da tecnologia e seus impactos ambivalentes em condições de modernidade reflexiva têm se desenvolvido e aprofundado como assuntos de relevância própria, nas Ciências Sociais do Ambiente, no geral e na Sociologia Ambiental, em particular.

Essas abordagens teóricas ressaltam a contribuição fundamental da ciência, do conhecimento especializado e da tecnologia tanto no que diz respeito ao controle e preservação do meio ambiente global, quanto à institucionalização da destruição da natureza, das ansiedades e das dúvidas sistêmicas e endêmicas em condições de modernidade tardia.

O regime de tecnologias simples da década de 1970, denominado "tecnologias de fim de tubo" está sendo substituído gradualmente por tecnologias ambientalmente mais avançadas (eco-inovações) que não apenas redirecionam os processos de produção rumo à sustentabilidade, mas também estão inseridas em sistemas tecnológicos que obedecem a rigorosos requerimentos ambientais (OLIVIERI, 2009).

A ciência viabiliza o desenvolvimento dessas tecnologias ambientalmente avançadas para reduzir os impactos ambientais negativos e aumentar a competitividade das empresas.

4) Procura por soluções preventivas e pelo aumento da eficiência produtiva

A ME supõe que o desenvolvimento tecnológico considera que a prevenção e a eficiência são dois paradigmas importantes e propõe duas formas de inovação ambiental: a inovação ambiental radical e a inovação ambiental incremental.

A inovação ambiental radical é caracterizada como a entrada de um produto ou processo realmente novo que pela sua trajetória tecnológica não é resultante de melhorias ambientais incrementais de uma tecnologia ambiental existente.

Já a inovação ambiental incremental, dada uma base tecnológica, representa as melhorias ambientais sucessivas em produtos e processos existentes com o objetivo de melhorar a qualidade ambiental, reduzir custos ou ampliar sua gama de aplicação.

No âmbito da ME, a eficiência não é considerada apenas um objetivo econômico ou técnico, é considerada um objetivo ambiental (Christoff, 2010).

Os pressupostos acima analisados representam as idéias centrais relacionadas com a $\mathrm{ME}$, no entanto provocam também reações diversas. Essas reações, em sua maioria, variam desde uma defesa extremada de suas principais hipóteses até duras críticas aos seus pressupostos.

As críticas são feitas por estudiosos que acreditam que a ME, que redefinem como "capitalismo sustentável", não será bem sucedida, especialmente por sua análise acrítica e conivente com a responsabilidade do capitalismo na crise ambiental (REDCLIFT e BENTON, 1994). 
As interpretações da ME, em grande medida, favoráveis à tecnologia e que permitem perceber o desenvolvimento tecnológico e o crescimento econômico harmonizados com a proteção ambiental, sâo criticadas por imprimir uma perspectiva relativamente otimista no que diz respeito ao fato de a melhora ambiental poder acontecer juntamente com 0 crescimento econômico.

Em alguns casos, identifica-se a TME com a Teoria da Sociedade do Risco, desenvolvida pelo sociólogo alemão Ulrich Beck também no final da década de 1980. De acordo com Buttel (2000), a ME precisa elaborar um corpo teórico mais coerente e embasado em teorias mais abrangentes sobre o Estado.

A ME deveria ser embasada em teorias mais bem estruturadas do desenvolvimento histórico e da mudança social, para avaliar melhor quais as novidades que ela apresenta e, assim, o quanto difere das teorias e trabalhos anteriores produzidos na Sociologia Ambiental, assim como em quais aspectos não acrescenta qualquer desenvolvimento teórico original (BUTTEL, 2000).

Faz-se necessário que, além da necessidade de novos desenvolvimentos teóricos, devam-se acrescentar mais pesquisas empíricas embasadas na ME, em diferentes lugares do mundo com a finalidade de testar melhor empiricamente as suas hipóteses e pressupostos conceituais (COHEN, 2006).

No que diz respeito às reações positivas, enfatizam-se tanto os fundamentos normativos da ME, quanto por ser uma teoria bem fundamentada do ponto de vista analítico.

A ME oferece uma perspectiva inovadora para compreender e avaliar as políticas públicas ambientais num contexto de mudanças globais, assim como pela sua compreensão da proteção ambiental, não como uma carga ou ônus para o desenvolvimento econômico, mas como uma precondição para um crescimento sustentável futuro. A ME reconhece a atual crise ambiental como uma evidência de uma omissão fundamental (falha) no funcionamento das instituições da sociedade moderna.

Em síntese, a ME tem gerado um efetivo intercâmbio intelectual e bastante entusiasmo no âmbito da pesquisa. É necessário analisar e avaliar a ME de forma mais sistemática, cuidadosa e rigorosa, o que implica a necessidade de maior desenvolvimento teórico futuro, ancorado em novas pesquisas empíricas. (FISHER e FREUDENBURG, 2001). 


\subsection{Algumas abordagens da ME}

Os pressupostos analisados mostram que a ME possui um embasamento teórico claro, no entanto as várias interpretações do seu significado a torna uma teoria imprecisa e confusa. Levando-se em consideração essa imprecisão de significado, dá-se ênfase nessa tese para a abordagem da ME como inovação tecnológica ambiental para que a análise empírica seja efetiva e os objetivos dessa pesquisa sejam atingidos.

Apesar da priorização da abordagem relacionada com a inovação tecnológica, são apresentadas também, algumas das outras abordagens mais importantes utilizadas pelos pesquisadores como: a ME como modernização política, como Teoria Social e como modernização da modernidade.

\subsubsection{A ME como modernização política}

O conceito de "modernização política" refere-se a um processo amplo de mudanças no âmbito político da sociedade. Tais mudanças políticas estão relacionadas com avanços econômicos, sociais e culturais, assim como com o processo de globalização, com a modernização reflexiva, com as trocas comerciais globais e com o processo de individualização.

A idéia principal diz respeito às consequências dessas mudanças estruturais para as percepções e práticas em relação à governança como às relações sociais e institucionais, incluindo as relações de poder entre Estado, mercado e sociedade civil (Olivieri, 2009).

No que diz respeito às relações entre o Estado e o mercado, Janicke (2010) argumenta que as discussões sobre a redefinição dessa relação por meio de uma reforma ambiental foram de grande importância para a emergência e o amadurecimento da ME.

Na década de 1970 e início da década 1980 havia desapontamento geral com o Estado que não tinha sido bem sucedido na tentativa de realizar a reforma ambiental. Pesquisadores defendiam que tanto o Estado com suas autoridades ambientais e agências reguladoras quanto o mercado, com seus vários atores e mecanismos de mercado, deveriam desenvolver novas regras com o objetivo de contribuir para a proteção ambiental.

Atualmente muitas pesquisas no âmbito da ME são direcionadas para a definição desses novos papéis do Estado e do mercado, mas esses novos papéis são definidos dentro da estrutura das sociedades modernas que são caracterizadas pelo moderno bem estar social dos Estados e pela economia orientada pelos mercados. Contudo a ME quando investiga as novas ou já existentes relações entre o Estado e o mercado para a reforma ambiental não reivindica mudanças na economia capitalista. 
Apesar de o sistema capitalista ser considerado importante causa da crise ambiental e nele existir claras restrições para a intervenção na economia do Estado-nação moderno, os modernistas ecológicos não apresentam um projeto de mudança como alternativa para a agenda estabelecida. Tal agenda não ultrapassa as agendas da economia moderna de mercado e do Estado moderno do bem estar social. Nesse contexto, a ME permanece com o paradigma da modernidade (MOL e JANICKE, 2010).

A partir da reflexão sobre as novas relações entre o Estado e o mercado, duas premissas se desenvolveram e gradualmente foram aceitas nos círculos da governança ambiental e da economia ambiental. A primeira delas argumenta que o mercado não é mais considerado como a causa da crise ambiental da mesma forma que era considerado pelos ambientalistas, notadamente, na década de 1970 (WEALE, 1993).

A segunda afirma que o Estado, no âmbito da ME, permanece como uma importante instituição, notadamente para a proteção do meio ambiente. Para participar e incentivar a reforma ambiental o Estado se reestruturou e deslocou-se de uma instituição burocrática, hierárquica e reativa, de comando e controle, para uma instituição mais flexível, descentralizada e preventiva com conexões com outros atores da sociedade e com a adoção de abordagens e instrumentos com o objetivo de guiar a sociedade na direção da sustentabilidade (WEALE, 1993).

A modernização política tem sido entendida como importante conceito complementar no âmbito dos estudos da ME como indutora de inovações políticas ambientais. A modernização política formulou a resposta da ME para corrigir as falhas do Estado, cujo conceito, no que se refere à ineficiência, à ineficácia e às fraquezas estruturais no processo de tomada de decisões, foi ilustrado na ciência política, notadamente com a ajuda das questões ambientais.

A integração de critérios ambientais no processo de decisão política nos setores de energia, transportes ou da agricultura, é um exemplo desse avanço na modernização política (HUBER, 1986).

O Japão é um dos países que apresentou maior avanço na modernização política, de acordo com Weider (1987), além de ter sido um dos países pioneiros na aplicação da ME. O país desenvolveu uma nova estratégia de organização do Estado que levou em consideração o conceito de reflexividade para abordar o envolvimento da sociedade industrial na política pública ambiental já que, em larga extensão, os problemas ambientais foram criados pela própria sociedade indústrial.

Pode-se afirmar que a modernização do Estado, embora ineficiente, caminha em paralelo com o processo de $\mathrm{ME}$, respondendo ao mesmo tipo de reivindicações para mudanças. 
Como resultado, para Janicke (1990), pode-se concluir que está ocorrendo uma reorientação política com as seguintes características:

- De burocrática, para uma regulamentação com ênfase na condução das condições estruturais e contextos de ação;

- $\quad$ Do modo estatal de lidar com os problemas para o modo da sociedade de manipulá-los com a inclusão do Estado;

- Da forma centralizada de resolução de problemas para forma descentralizada;

- Da estrura exclusiva dos tomadores de decisões para outra estrutura mais inclusiva e participativa;

- $\quad$ Do estilo de política imperativa para soluções negociadas;

- Do padrão de política reativa para o padrão de política fortemente preventiva e;

- Da condução baseada nas despesas públicas para a condução fortemente baseada nas receitas públicas (taxas, tarifas, impostos).

Nas úlltimas duas décadas desenvolveu-se nova estrutura dupla do sistema políticoadministrativo, de acordo com Janicke (1992), conforme o Quadro abaixo.

Quadro 2.1. A nova estrutura dupla do Estado: hierarquia e cooperação

\begin{tabular}{|c|c|}
\hline Hierarquia & Cooperação \\
\hline Intervenção vertical & Cooperação Horizontal \\
\hline Legitimização democrática & Legitimização por consenso \\
\hline Baseada na maioria & Baseado na minoria \\
\hline Estilo de política imperativa & Estilo de política dialógica \\
\hline Direção baseada no projeto & Procedimentalização \\
\hline Centralidade & Organização decentralizada \\
\hline Institucionalização forte & Institucionalização fraca \\
\hline
\end{tabular}

Fonte: Janicke (1992) in The ecological modernization reader (Mol and Spaargaren, 2009), p34.

Ambas as estruturas se relacionam e não representam alternativas exclusivas. O que importa são as variações e o volume de intervenção estatal. Particularmente, no setor ambiental pode-se confrontar com a coexistência complexa e a interligação da intervenção hierárquica, da intervenção cooperativa e da autoregulação (JANICKE, 1990).

Nos tempos aturais existe consenso de que o Estado burocrático constitucional não é mais a única autoridade condutora legítima. Os vários tipos de intervenção oferecem novas oportunidades. Basicamente, uma dupla mudança de paradigmateve lugar nas crenças das 
sociedades industriais: a primeira está relacionada com o padrão de crescimento e com seu desempenho ecológico enquanto que a segunda está relacionada com o mecanismo de condução política. Ambas as reorientações presumidamente abrirão perspectivas reais no futuro somente se e quando forem realizadas e seguidas de forma consistente.

\subsubsection{A ME como teoria social}

A perspectiva da ME como uma teoria social foi desenvolvida, principalmente no âmbito da Sociologia Ambiental. Os primeiros estudos foram elaborados na Holanda com o objetivo de caracterizar a ME como uma teoria mais formal e sistemática.

As publicações iniciais foram de Spaargaren e Mol em 1992, Sociology, Evironment, And Modernity: Ecological Modernization as a Theory of Social Change, nas quais os autores desenvolveram uma teoria coerente que foi subsídio para amplas publicações adicionais e debates sobre características e conceitos da ME.

Gradualmente, Spaargaren e Mol também foram desenvolvendo essa teroria em relação a outras teorias sociais. Por exemplo, discutiram as similaridades e as diferenças entre a ME e a Teoria da sociedade de risco de Ulrich Beck (Mol and Spaargaren, 1993; Blowers, 1997), compararam a ME com a desindustrialização, o neomarxismo e com as escolas de pensamento da pós-modernidade (Mol, 1995, Spaargaren, 1997, Mol and Spaargaren, 2000; Mol and Spaargaren, 2005b); vincularam a ME com ampla categoria da modernização reflexiva (Mol 1996; Mol and Spaargaren 2000); confrontaram a ME com as teorias da globalização (Mol 2001), teorias do consumo (Spaargaren 2003) e mais recentemente conectaram a ME com a sociologia das redes e dos fluxos de informação (Mol and Spaargaren 2006: Spaargaren, 2006).

Outros autores também participaram desses debates sobre os fundamentos teóricos da ME. A ME foi desenvolvida como a história das teorias da modernização, linha de pesquisa para a qual Seippel (2000), contribuiu de forma significativa. Já Weale (1992; 1993), Hajer (1995, 2010) e outros, desenvolveram a noção de ME como um novo discurso sobre o meio ambiente, no qual a dicotomia convencional entre meio ambiente e economia foi substituída pela nova idéia de que ambos poderiam seguir juntos.

Desde que a ME foi pensada como um conceito ou teoria tem ocorrido debates significativos com outras teorias das ciências sociais ambientais. Trata-se de prática comum já que o desenvolvimento de uma teoria nas ciências sociais caminha por meio do debate. Nesse contexto, um dos debates principais envolve a questão da crise ecológica ser interpretada como um confronto da sociedade industrial com seus próprios efeitos colaterais, um confronto com a reflexividade. 
Nesse sentido, a ME se confunde com o auto-risco ou a auto-dissolução intencional proposta por Beck, é a reflexividade que produz a crise ecológica. Os avanços tecnológicos, políticos e sociais atingidos pelas instituições da sociedade moderna (Estado, mercado, ciência e tecnologia) produzem a crise ecológica. A Reflexividade relata a modernidade como formação social que constantemente e imediatamente a erode (BECK, 1997, BECK, 2010).

No âmbito dessa abordagem social da ME, e considerando o princípio da modernização reflexiva, as próprias instituições da modernidade devem encontrar as soluções para os problemas ambientais que ela própria criou. A sociologia ambiental, nesse sentido, incumbe-se de desenvolver uma teoria sólida e crível para explicar e compreender como e até quanto as instituições modernas foram modificadas pela crise ambiental e quais seriam as soluções viáveis para superar essa crise. Dentre as soluções propostas, uma delas diz respeito à reorientação dos padrões de produção e de consumo rumo à sustentabilidade.

As mudanças nas práticas de produção recomendadas pela ME abarcam principalmente o uso das inovações tecnológicas orientadas ambientalmente, tanto as inovações ambientais radicais quanto as incrementais. A idéia é a obtenção de melhorias ambientais sucessivas em produtos e processos existentes, ou a transformação desses processos, com o objetivo de melhorar a qualidade ambiental, reduzir custos, aumentar a eficiência ambiental e reduzir o consumo de recursos.

Já, as mudanças nas práticas de consumo recomendadas pela ME envolvem a formação de um mercado consumidor para produtos ambientalmente sustentáveis. Com relação ao consumo desses produtos (consumo verde), a ME argumenta que o desenvolvimento de tal prática criaria nichos de mercados e aumentaria as vantagens competitivas de empresas que decidissem modificar seus produtos e processos reduzindo seu impacto ambiental (Milanez, 2009, p.81). Dessa forma, a existência de consumidores com alto nível de preocupação ambiental criaria motivações para mudanças nos padrões de produção (SPAARGAREN, 2003).

Para que os objetivos traçados pela ME, enquanto teoria social sejam atingidos, tornase necessário identificar quais formas de reflexividade podem ser discernidas no projeto da ME. Quais processos de desinstitucionalização e reinstitucionalização devem ser considerados e quais projetos sociais devem ser adicionados sob a bandeira da proteção ambiental.

Torna-se importante a esse respeito, identificar as regulações ambientais dos países que são internacionalmente vistos como os mais avançados exemplos de ME, como os países da Europa Ocidental, com destaque para a Alemanha e a Holanda, onde existe 
ampla coalisão social para o alcance da institucionalização das idéias ecomodernistas Weale (1993).

Para Hajer (2010), essa institucionalização baseia-se na interpretação da ME que é feita pelas instituições da modernidade. A dinâmica social da ME não é uma dinâmica ideal como se poderia supor. Pode-se observar pelo menos 4 linhas distintas de desenvolvimento dessa dinâmica.

A primeira delas, diz que o efeito direto da ME é a racionalização da ecologia, por meio do aperfeiçoamento conceitual e institucional das estruturas burocráticas existentes e a criação de novas, seja pelo Estado ou pelas novas associações corporativistas.

A segunda linha é a tecnização da ecologia, representada principalmente pelo avanço nos países líderes da ecomodernização, da reorientação do planejamento estratégico de grandes firmas multinacionais como a SIEMENS, DASA e BMW, que são centrais na coalisão do discurso ecomodernista e na criação de eco-industriais. Essas empresas têm idéia de quais novos atores são relevantes e trabalham efetivamente, no sentido de estabelecer novos arranjos institucionais.

Enfatiza-se que também as ONGs como Greenpeace, as associações de comércio e os políticos são colaboradores em potencial para impulsionar a ME nesta direção.

A terceira linha de desenvolvimento que a ME produziu foi a tendência para a ecologização do social, que não é considerada uma resposta para a crise ecológica, mas uma estratégia que defende a criação e a manutenção de coligações em toda a sociedade para a proteção ambiental. Isto significa, por exemplo, acompanhar a integração futura de mercados globais considerando, principalmente as dimensões social e ecológica. Nesse contexto surgem iniciativas como a inclusão de um capítulo social ao Tratado de Maastricht, a adição de um parágrafo ecológico no GATT e a criação de um Fundo de Financiamento "Verde" no Banco Mundial.

\subsubsection{A ME como modernização da modernidade}

No contexto sociológico o significado de modernização está relacionado com a distinção entre sociedades primitivas, sociedades tradicionais e sociedades modernas. Não existe um consenso sobre quando surgiram as sociedades modernas.

Para alguns autores as sociedades modernas surgiram a partir da Idade Média, por volta de 1.500, enquanto que para outros pesquisadores, o começo da modernização coincide com a revolução industrial, no século XVIII. O período que marca o início que marca o início da modernidade é bastante diversificado e depende de autores e dos critérios que são utilizados para a análise. 
Os critérios mais utilizados para a caracterização da modernidade são os avanços da ciência e da tecnologia, altos níveis de produção e de consumo industrial, a intensificação das práticas comerciais e o desenvolvimento de mercados baseados em sólidos sistemas financeiros e de crédito, o estabelecimento crível de legislação pública e civil e os avanços na gestão de problemas amabientais além da observação dos direitos individuais, dentre outros.

As sociedades quando consideradas como um sistema tem um número diversificado de funções e de estruturas que a compõe e a modernização, então, é o processo por meio do qual essas funções e estruturas da sociedade são continuamente desenvolvidas e aprimoradas para níveis de complexidade mais altos. No âmbito dessa abordagem, a ME propõe que esse processo de modernização priorize a dimensão ambiental, nesse sentido a ME significa modernizar a modernidade de forma sustentável (HUBER, 2010).

O processo de modernização desenvolveu-se tendo como pano de fundo as sociedades tradicionais. As classes feudais baseadas na hereditariedade foram substituídas por estruturas de classes meritocráticas baseadas na realização individual. Camponeses e artesãos foram substituídos por trabalhadores industriais e banqueiros e os cavalos e as carroças por estradas de ferro, barcos a vapor e aviões.

As mudanças sociais estabelecidas foram fundamentais e resultaram em crises severas e catástrofes, desde 1840. Ficaram conhecidas como as questões sociais, que fortaleceram a regulação e a construção da instituição do trabalho moderno, bem estar e participação em massa.

Para Huber (2010), no começo dos anos 1990, teve início novo estágio da modernização conhecido como pós-modernidade ou modernidade tardia. Nessas sociedades avançadas não existem muitas características tradicionais para serem ainda modernizadas e a partir dessa fase, o processo da modernização será caracterizado pela substituição das estruturas do início da modernidade pelas estruturas desse novo período.

O conhecimento econômico, a baixa qualificação e o antigo trabalhador industrial já foram substituídos em algumas sociedades e estão sendo ainda substituídos em outras pelas máquinas automáticas e pelos profissionais com alta qualificação educacional. As antigas indústrias de chaminés estão sendo substituídas pelas indústrias modernas de alta tecnologia. O foco não é mais na industrialização, mas na reestruturação das indústrias, particularmente com alto nível de conscientização ecológica.

Nesse contexto, a ME propõe que a reestruturação do sistema industrial moderno priorize a dimensão ecológica, já que a questão social, nessa perspectiva, já foi resolvida. Contudo a reestruturação da indústria não será possível se todos os subsistemas que compõem a modernização não interagirem harmoniosamente. 
A sociedade moderna pode ser analisada como um sistema composto por vários outros subsistemas (HUBER, 2010):

- O sistema Operativo - representa o trabalho humano baseado na tecnologia. É o mundo da produção e do consumo formal e informal;

- $\quad$ O sistema Econômico - representa o setor financeiro e os mercados;

- $\quad$ O sistema Ordenativo - Inclui o governo, administração pública e gestão privada, baseadas na lei e na autoridade;

- O Sistema Político - Inclui os discursos, as agendas, os processos de tomada de decisão considerando não só o governo, mas também todo tipo de instituições inclusive as estabelecidas pela sociedade civil e ;

- O Sistema Cultural - Inclui os valores, conhecimento, estilos de expressão, educação e estilos de vida baseados na cosmologia e nas religiões.

Essas dimensões, ou subsistemas, estão envolvidos em um processo complexo de inter-relação e de direção conjunta. Nenhum desses subsistemas poderia ser considerado mais importante do que o outro quando se considera quem determina evolução da sociedade. Mas, o centro do sistema pode ser mudado de um subsistema para o outro no decorrer do tempo.

Afirma-se que no transcorrer da história da modernidade, percebeu-se que a sociedade prioriza mais ou menos, algumas dessas dimensões em determinados momentos. Durante o Renascimento, por exemplo, o foco foi no sistema cultural, na religião, nos valores e nos conhecimentos para a formação da mentalidade moderna, em particular, a moderna concepção do ser humano, de Deus e do Mundo.

Nos séculos XVI e XVII, a ênfase foi na construção do Estado e do governo, caracterizada pela preocupação com a forma de governar, de gerir e como policiar efetivamente. No século XVIII e durante o século XIX, a sociedade preocupou-se com a economia e finalmente no século $X X$, a priorização é a tecnologia na condição de fator produtivo mais importante da sociedade moderna.

A idéia de mudança de foco no ciclo de vida da modernização, em nenhum momento, incluiu a evolução conjunta de todos os subsistemas. Todos os subsistemas continuam a modernizar-se durante todo tempo, e isso resulta, de forma geral, em um processo complicado e propenso a crises. Interessante ressaltar que a mudança social ocorreu de forma linear e regular.

A modernização sustentável da modernidade inclui contribuição contínua e efetiva de cada subsistema e envolve necessariamente;

- $\quad$ Conscientização ecológica; 
- $\quad$ Ética ambiental;

- $\quad$ Conhecimento ecológico;

- Comportamento responsável;

- Estabelecimento de uma agenda orientada para o meio ambiente;

- Vontade política para a construção de um sistema de tomada de decisão;

- Modo adequado de legislar e elaborar a legislação, as finanças e os mercados e;

- Inovação tecnológica orientada ambientalmente.

Essa abordagem da ME afirma que num primeiro momento, é a tecnologia que determina a qualidade ecológica dos impactos da atividade humana na biosfera e na geosfera. Mas, as inovações tecnológicas ambientais não serão possíveis sem todos os subsistemas funcionando harmoniosamente. A ME precisa de impulso correspondente de todos os subsistemas da sociedade e se apenas um desses sistemas é desconsiderado, o processo de ME será inviável.

\subsubsection{A ME como inovação tecnológica ambiental}

Essa abordagem enfoca o desenvolvimento de novas tecnologias ambientais e busca identificar o desenvolvimento de processos produtivos que sejam mais limpos e menos intensivos em recursos naturais. A super-industrialização foi pensada para lidar com os impactos ambientais da sociedade industrial, em grande parte, por meio da transformação da produção industrial baseada no desenvolvimento e na aplicação de tecnologias avançadas (HUBER, 1986).

Até certo ponto, as idéias de Huber estão de acordo com a ampla discussão da modernidade reflexiva de sociedade de risco que foi debatida por Guidens, Beck e Lash. Esses autores sugeriram que a moderna sociedade industrial está se tornando menos segura em relação ao seu futuro e ela está respondendo a essa insegurança procurando mudar a natureza do desenvolvimento industrial.

Desde a fase inicial, com a contribuição marcante de Huber, a ME tem associado suas idéias com um número diversificado de perspectivas acadêmicas que prioriza a inovação tecnológica. Inicialmente, Janicke e Simonis enfatizaram a inovação industrial e defenderam a reestruturação macroeconômica industrial como outro componente essencial da ME. Defenderam que as mudanças tecnológicas eram importantes juntamente com uma mudança na composição das economias industriais movendo-se das indústrias pesadas para uma indústria menos intensiva em recursos e mais intensiva na eficiência. 
Janicke (2010), afirma que o conceito de ME tem sido usado para descrever uma abordagem da Política Pública Ambiental orientada para a inovação tecnológica e fundamentada na dimensão tecnológica. Dessa forma, a ME difere de uma abordagem apoiada exclusivamente na proteção ambiental, nas tecnologias de "fim de tubo", uma vez que leva em consideração todas as medidas que impliquem o fomento para a inovação ecológica, apoiando também a difusão dessas inovações.

Em função da ampla aceitação da idéia da ME tem surgido diversos conceitos alternativos com o objetivo de explicá-la de forma mais efetiva, dentre eles destaca-se o conceito de inovação eco-eficiente que está sendo utilizado como sinônimo da ME e que diz respeito à adoção de tecnologias ambientalmente benignas que aumentam a produtividade dos recursos e produz benefícios econômicos e ambientais simultâneos para as empresas.

Weale (1992) identificou a ME como um programa de governo baseado em um plano estratégico e em instrumentos de política inovativa com a indústria sendo o foco das atenções. A ação governamental consistente com a ME é baseada na crença de que não existe conflito entre a proteção ambiental e o crescimento econômico e a abordagem dos problemas amblientais pela indústria poderia torná-la mais eficiente e assegurar a sustentabilidade do crescimento.

Pode-se afirmar, de certa forma, que a inovação ambiental é parte central da ME. Partindo do princípio de que a ME desconsidera a redução do consumo como estratégia para reduzir os problemas ambientais, somente mudanças no processo de produção seriam capazes de reduzir os problemas ambientais. Sendo assim, os componentes de mudança social e política pública teriam como principal função criar condições ou motivar o desenvolvimento e a adoção de inovações ambientais (MILANEZ, 2009).

Como resultado do trabalho de um número crescente de pesquisadores, a ME tem melhorado e se estabeleceu com uma relativa clareza de idéias, embora seja importante distinguir o uso descritivo do conceito e sua implementação prescritiva. Com respeito à dimensão prescritiva a ME vincula os problemas ambientais como sendo o resultado do insdustrialismo.

De acordo com premissas da ME, os problemas ambientais podem ser abordados no âmbito da modernidade por meio de ações do Estado e da Indústria que conduzem a teoria no rumo do crescimento econômico com proteção ambiental.

Da parte do Estado a necessidade é por engajamento ativo de seus atores na promoção da $\mathrm{ME}$ e na gestão dos impactos ambientais que demandará planejamento estratégico e promoção de mudanças estruturais no nível macro-econômico, com ênfase no uso menos intensivo de recursos e em formas ambientalmente sustentáveis de geração de renda. Para o alcance desses objetivos torna-se necessário o uso de instrumentos 
inovativos de política e de abordagens que substitua as tradicionais regulações ambientais por regulações que incentivam a melhoria ambiental.

$\mathrm{Na}$ indústria, a ME está ligada com a invenção e a difusão de novas tecnologias e de técnicas de produção que incentivam simultaneamente benefícios econômicos e ambientais. A regulação ambiental inovativa elaborada pelas agências governamentais devem dirigir o processo de inovação na indústria para que alcance esse objetivo.

Entretanto, torna-se necessária atenção especial para o processo de elaboração das regulações ambientais para que a burocracia governamental não prejudique o processo da ME. Mol (1995) argumenta que a burocacia não favorece o processo de inovação na indústria, pois representa falta de conhecimento que impede a criação inventiva e produtiva.

Em geral, a modernização, em termos econômicos, é a melhora sistemática, baseada em conhecimento intensivo, dos processos de produção e dos produtos gerados por esses processos produtivos. A urgência para se modernizar parece ser uma compulsão inerente às economias capitalistas de mercado, e a crescente competição pela inovação nos países industrializados tem conduzido a uma aceleração contínua da modernização tecnológica.

Para os defensores da ME, é possível influenciar a direção do progresso tecnológico nas sociedades capitalistas de mercado. De fato, uma governança por uma ME significa, sobretudo, o desenho e a implementação de ações políticas para o exercício de tal influência. A principal tarefa consiste em mudar a direção do progresso tecnológico e colocar a compulsão pela inovação a serviço do meio ambiente.

A ênfase coloca-se na possibilidade de gerar soluções de cunho tecnológico, ecológico-econômicas que impliquem num resultado "ganhador-ganhador" e que possam ser alcançadas, acima de tudo, por meio da redução dos custos da competição para a inovação.

O conceito de Inovação, normalmente abarca todos os estágios de uma nova atividade econômica incluindo a pesquisa, a descoberta, a experimentação, o desenvolvimento, a imitação e a adoção de novos produtos, novos processos e novas formas organizacionais. A ME pode acontecer na forma de uma inovação radical, quando envolvem mudanças descontínuas e promovem a introdução de novas técnicas e tecnologias (tecnologias limpas), ou incremental, quando envolvem melhoramento gradual de técnicas e de tecnologias já existentes (tecnologias mais limpas) (MURPHY, 2011).

Enquanto as inovações radicais frequentemente se apoiam nos melhoramentos incrementais para serem bem sucedidas, as inovações incrementais se defrontam com a diminuição dos retornos marginais e com limites econômicos e técnicos. A adoção de uma mudança radical ou descontínua é um pré-requisito para fases bem sucedidas da inovação incremental. 
Além das características específicas de cada inovação como seu custo ou qualidade, sua adoção também se baseia na sua compatibilidade com sistemas e estruturas. Novas inovações dependem de um sistema ou de uma rede de relações sem as quais a sua adoção é impossível. Como consequência, novas técnicas e tecnologias devem ser introduzidas em sistemas que tem frequentemente sido desenvolvidos para as técnicas e as tecnologias mais antigas.

Consequentemente a introdução de uma nova inovação pode requerer mudanças de longo alcance para assegurar a compatibilidade com o sistema como um todo. Podem surgir considerável resistência e inércia no processo. Por exemplo, as empresas que tem dominado com sucesso as operações que envolvem as velhas técnicas e tecnologias comumente enfrentam dificuldades relacionadas com habilidade e conhecimento para a aplicação bem sucedida das novas técnicas e tecnologias. (OCDE, 1997)

Dependendo da habilidade necessária para a adoção de uma inovação pode-se priorizar uma inovação que requer somente mudanças incrementais em detrimento daquela que requer uma mudança radical. Consequentemente, a dinâmica natural da inovação tende a favorecer a inovação incremental, mais do que a inovação radical e como consequência normalmente, a mudança assume uma trajetória específica e de uma forma evolutiva.

Porém, a habilidade de uma nova técnica ou tecnologia para influenciar sistemas e estruturas já existentes varia ao longo do tempo, como resultado da dinâmica e do impacto da escala e dos efeitos da aprendizagem do processo.

Esses efeitos significam que novas inovações provocam melhoramentos na qualidade e na redução dos custos associados ao processo com a expansão e experiência acumuladas com sua aplicação. Assim, a eficácia e a eficiência de uma nova inovação aumentam com a sua difusão de modo que em vez de encontrarem retornos decrescentes, as inovações geralmente experimentam um período de retornos crescentes a partir do momento que são adotadas.

Enquanto esses efeitos parecem ser benéficos, os seus impactos aumentam por um período, tanto pelo lado da oferta quanto pelo lado da procura e tendem a se tornar cada vez mais presos à trajetória particular da inovação selecionada. Por comparação, qualquer que seja seu potencial aparente, aquelas inovações que não são beneficiadas pela dinâmica da escala e dos efeitos de aprendizagem são, ou são percebidas como, caras, inadequadas, incompatíveis, não comprovadas, desconhecidas e sem o necessário mecanismo de suporte.

Em essência, embora, uma inovação potencialmente benéfica pode não ser selecionada devido a sua ineficiência inicial, paradoxalmente, a única maneira dela se tornar eficiente é sendo selecionada (OCDE, 1997). A racionalidade dos atores na escolha 
referente ao desenvolvimento e ao uso de uma nova inovação é delimitada pela natureza do sistema já existente.

Dessa análise percebe-se que existe geralmente, um viés embutido na direção de uma mudança incremental ao invés de uma mudança radical. Esse viés surge particularmente do desejo de não desperdiçar os sistemas já existentes, mas está também ligado a outras barreiras associadas com as inovacões, por exemplo, capacidade de gestão e acesso ao capital.

Embora a preferência por técnicas e tecnologias já existentes, antes da introdução de novas, pode parecer ser racional no curto ou médio prazo, é evidente que se exploradas sozinhas, as inovações incrementais se defrontam com a diminuição de retornos marginais assim como com uma escalada nos custos para sustentar os melhoramentos conseguidos.

Enquanto as novas técnicas e tecnologias tem o potencial de permitir melhoramentos contínuos de desempenho por um longo período e ausência da escalada de preços, no curto prazo e médio prazo elas tendem a não ser adotadas. Isto é devido em parte, porque elas ainda precisam se beneficiar da escala e dos efeitos da aprendizagem para poderem reduzir seus custos e aumentar sua qualidade.

O aperfeiçoamento e a inovação tecnológica afetam diversas dimensões, tais como a intensidade das matérias primas (uso eficiente das matérias primas), a intensidade energética (o uso eficiente da energia), intensidade de transpporte (logísticas eficientes), intensidade da superfície (uso eficiente do espaço) e intensidade do risco (relativamente às indústrias, sunstâncias e produtos).

A eco-inovação descreve a adoção inicial, no âmbito do mercado, de uma nova tecnologia que pode melhorar as fases do ciclo de vida de um produto. Os resultados, do ponto de vista ecológico, da inovação tecnológica induzida pelo meio ambiente dependem da sua radicalidade e do grau de sua difusão.

Olivieri (2009) destaca duas forças motrizes da ME que, no longo prazo, podem influenciar-se mutuamente, aumentando dessa forma, as dinâmicas existentes da inovação ambiental.

Estes dois fatores são:

a) O papel de uma regulação governamental inteligente (smart regulation);

b) Os riscos crescentes nos negócios para os poluidores, no contexto de uma governança ambiental de múltiplos níveis.

Embora a presença desses fatores possa incrementar o potencial de longo prazo para uma governança ambiental criativa, apresentam-se importantes limites para uma estratégia de ME, que devem ser levados em conta.

Existem implicações políticas, que se desprendem de uma estratégia de ME, entendida, especialmente como a inovação e a difusão de tecnologias ambientais. As 
inovações tecnológicas ambientais, se comparadas com outras inovações tecnológicas, possuem três características distintas:

1) Necessitam de apoio político ou pelo menos, organizados socialmente, devido às falhas de mercado. É por esse motivo que o conceito de ME é também essencialmente político;

2) As inovações ambientais são uma resposta aos problemas que têm, ou que terão uma dimensão global. Portanto elas tendem a ter um mercado global potencial, baseado em necessidades ambientais globais;

3) O próprio crescimento industrial global cria novas demandas por inovações ambientais, uma vez que muito dos recursos naturais são escassos e a capacidade de abasorção do planeta é limitada;

Diversos estudos empíricos realizados sobre os determinantes das eco-inovações confirmam que precisam, invariavelmente, de apoio político. Existe normalmente uma relação importante entre os tomadores de decisão no âmbito governamental e os inovadores tecnológicos dos negócios.

Os políticos que são a favor de soluções tecnológicas baseadas no mercado cooperam com inovadores industriais, os quais, por sua vez, procuram apoio regulatório para suas respectivas tecnologias. No entanto, a regulação ambiental, não se restringe, necessariamente, à inovação. Para além dessa situação, as considerações ambientais têm se transformado crescentemente num motor para a ME e numa importante dimensão da competição para a inovação.

\subsection{As oportunidades para o melhoramento ambiental na indústria}

As características genéricas do processo de inovação são refletidas nas várias opções disponíveis para as empresas que pretendem melhorar o seu desempenho ambiental. Em tais casos, as empresas se defrontam com um número de escolhas relacionadas com aquelas opções tecnológicas e organizacionais que podem melhorar de forma incremental o desempenho ambiental de operações já existentes e relacionadas com opções estratégicas que oferecem o potencial para mudanças mais radicais.

Em relação às oportunidades tecnológicas para o melhoramento ambiental, as empresas geralmente se defrontam com escolhas entre as tecnologias de controle e as tecnologias limpas, ou pelo menos, mais limpas. As tecnologias de controle são as adições às tecnologias de fim de tubo nos processos de produção que capturam e ou tratam uma emissão de resíduos a fim de limitar o seu impacto ambiental.

Por contraste, as tecnologias limpas são geralmente processos ou produtos que tem como proposta principal um objetivo não ambiental, mas que incluem considerações 
ambientais em seu projeto para evitar ou reduzir o seu impacto sobre o meio ambiente. Dessa forma, tecnologias de controle podem ser vistas como uma resposta reativa para as emissões enquanto as tecnologias limpas tem natureza antecipatória.

Em função de sua natureza reativa, as tecnologias de controle não requerem normalmente um redesenho significativo de processos e produtos com os quais elas estão associadas. Também, como existe um mercado distinto para as tecnologias de controle, os fornecedores são facilmente identificados e uma análise direta de seu desempenho econômico e ambiental é praticamente automática.

Consequentemente, elas são relativamente fáceis de comprar e instalar quando comparadas com as tecnologias limpas. Em contraste e como uma consequência de sua natureza integrada, a compatibilidade das tecnologias limpas com os sistemas já exisitentes é usualmente mais limitada. Isto significa que é frequentemente mais caro adaptar tecnologias limpas em processos já existentes. Além disso, como elas são desenhadas para ser integradas em processos já existentes, caso a caso, as análises genéricas de seu desempenho econômico e ambiental são normalmente mais complicadas.

Coletivamente, essas características tendem a suportar o desenvolvimento e a aplicação de tecnologias de controle, particularmente como uma consequência de sua conveniência de seu curto - médio prazo. Este viés inicial na direção das tecnologias de controle tem sido composto pela questão da escala e dos efeitos da aprendizagem que permitem um aumento no seu preço e uma melhoria no seu desempenho. Em muitos casos, as tecnologias limpas tem ainda se beneficiadas de processos similares porque elas têm sido menos adotadas.

Essa tem sido a tendência, apesar das tecnologias limpas serem consideradas economicamente mais eficientes e ambientalmente mais eficazes no médio e no longo prazo e melhorar a eficiência dos recursos, a eficiência econômica e a abordagem dos impactos ambientais na fonte.

Além de utilizarem os investimentos em novas tecnologias, as companhias podem melhorar o seu desempenho ambiental por meio de mudanças organizacionais e a adoção de novas técnicas de gestão. Inovações organizacionais dessa natureza podem ser adaptadas de forma isolada ou podem ser associadas com mudanças tecnológicas.

Onde os investimentos tecnológicos são necessários, as inovações de gestão ou organizacional podem ajudar para assegurar os benefícios diretos e indiretos associados com a nova tecnologia, particularmente por facilitar ainda mais a melhoria incremental.

A aplicação de sistemas de gestão, tradicionalmente relacionada com qualidade, mas também utilizada para saúde, segurança e meio ambiente, é uma das inovações organizacionais mais importantes no mundo dos negócios, devido à forma que vincula sistemas organizacionais díspares em um sistema geral, integrado e organizado. 
Potencialmente tais inovações organizacionais trazem rápidos ganhos econômicos e ambientais além de ter um impacto positivo num ambiente onde novas tecnologias podem ser introduzidas e assim fortalecendo o potencial para as tecnologias limpas serem integradas em sistemas já existentes.

Finalmente, em associação com as mudanças tecnológicas e organizacionais no curto e no médio prazo, as empresas podem melhorar o desempenho ambiental por meio da integração das considerações ambientais com seus planos estratégicos e com seus processos de gestão operacionais. Enquanto que melhorias incrementais advindas de mudanças estruturais ou organizacionais em processos já existentes podem assegurar alguns benefícios, os melhoramentos incrementais sem acompanahamento de outros melhoramentos se defrontarn com retornos marginais menores, ao longo do tempo.

Entretanto isto pode ser evitado se oportunidades para mais mudanças radicais forem consideradas na medida em que as empresas incluam considerações ambientais nos processos de decisão estratégica. Desta maneira as empresas podem explorar as oportunidades de mudanças radicais, cujos benefícios podem ser reforçados posteriormente por fases subsequentes de melhoramentos incrementais.

Fica evidente que existem diversas opções viáveis para as empresas que procuram melhorar o seu desempenho ambiental. Estas opções estão relacionadas com a natureza da inovação industrial que podem ser apresentadas de acordo com o quadro a seguir.

Quadro 2.2. Natureza da inovação industrial

\begin{tabular}{|l|l|}
\hline \multicolumn{1}{|c|}{ Dimensões } & Foco \\
\hline Dimensão Tecnológica & Tecnologia de controle e Tecnologia limpa \\
\hline Dimensão Organizacional & Técnicas e Tecnologias de gestão \\
\hline Dimensão estratégica & Mudanças radicais e Mudanças incrementais \\
\hline
\end{tabular}

Fonte: Elaboração própria, 2015.

Embora este quadro usualmente, sintetiza as discussões anteriores, torna-se importante ressaltar que na realidade as categorias identificadas não existem. Por exemplo, a classificação de alguma coisa como tecnologia de controle ou tecnologia limpa pode não ser sempre clara. Também como dito acima, o quadro não reconhece as barreiras de inovação que tendem se tornar mais evidentes quanto mais mudanças descontínuas ou mais radicais são procuradas.

Assim as barreiras à inovação aumentam na medida em que as empresas se movem das tecnologias de controle para as tecnologias limpas, na medida em que complementam as mudanças tecnológicas com mudanças organizacionais e na medida em que exploram as oportunidades estratégicas assim como as operacionais para melhorias. 
Estas barreiras à inovação reduzem a probabilidade das novas técnicas e tecnologias serem desenvolvidas e adotadas. Consequentemente, elas tendem a aumentar as dependências geradas de curto prazo particularmente, pelos impactos de escala e de efeitos de aprendizagem que fomenta o desenvolvimento da atividade industrial. Entretanto, dado o potencial de longo prazo de novas técnicas e tecnologias, torna-se apropriado examinar o papel que a regulação pode desempenhar na ajuda às empresas para superar as barreiras à inovação.

A regulação tem um papel importante na competição política pela inovação ambiental e pode ser identificada como uma força matriz-chave, agindo como pano de fundo da inovação. Embora, de acordo com a argumentação da economia tradicional neoclássica a regulação impõe altos custos sobre as empresas e prejudica a inovação e a competitividade, observa-se cada vez mais uma relação positiva entre a regulação ambiental e a competitividade de um determinado país.

O papel do governo, nesse contexto, tem se transformado numa necessidade funcional e deve ser reinventado e fortalecido, especialmente se a competição pela inovação e a proteção ambiental estão em jogo. A regulação pode criar impedimentos para as empresas, porém apresenta, de forma geral, um número de vantagens distintas, como por exemplo:

a) A regulação pode criar, ou ajudar a criar, mercados para indústrias domésticas;

b) A regulação, com frequência iniciada através de cenários de tendências regulatórias e direcionada para uma harmonização global, aumenta a previsibilidade dos mercados. A antecipação das tendências regulatórias é, assim, um comportamento típico das empresas inovadoras sob condições globais de insegurança e complexidade crescente;

c) A regulação pode facilitar as atividades no mundo dos negócios. Em contraste com as abordagens voluntárias, as empresas afetadas não devem se preocupar se seus competidores estabelecerão as mesmas medidas e;

d) A regulação também reduz os impedimentos internos nas empresas para implementar mudanças tecnológicas.

Apesar de a regulação ter celebrado uma retormada nos tempos atuais, devido especialmente ao impacto sistêmico da crise econômica global em curso, os modos da regulação estão se transformando, uma vez que o foco está agora numa regulação inteligente ou em uma boa regulação ambiental.

Os instrumentos regulatórios altamente sofisticados são descritos como instrumentos com conhecimento incorporado, uma das características que define a sociedade da informação globalizada. Isto é especialmente plausível ao se retornar ao conceito de ME, 
uma vez que este tem pontos em comum com uma regulação ambiental orientada para a inovação.

Contudo, para o desenvolvimento de uma tecnologia ambiental efetiva, autores da ME mencionam que é essencial a elaboração de uma regulação ambiental capaz de incentivar e fortalecer a inovação ambiental. Um dos fatores-chave é a existência de uma estrutura de inovação eficaz, na qual o sistema de ciência e tecnologia é capaz de identificar problemas ambientais e trabalhar junto com as empresas e governo no desenvolvimento de novas soluções tecnológicas (LUNDQVIST, 2000).

\subsection{Considerações sobre as inovações no consumo e na produção como preocupações centrais da ME.}

Autores da ME tem considerado a transição para uma sociedade ecológica caracterizada por sistemas de consumo e de produção ecologicamente modernizados, sob várias perspectivas. No entanto, essas abordagens têm negligenciado consumidores como participantes essenciais na conceituação e na gestão da mudança ambiental. Recentemente, os cientistas sociais ambientais começaram a articular uma mudança mais efetiva desde a produção até o consumo e que leva em consideração as múltiplas e de certa forma, incongruentes práticas dos consumidores (SPAARGAREN E COHEN, 2010).

Os desafios que são impostos para o consumo aumentam continuadamente e os estudiosos da ME discutem como transitar entre a modernidade e as tecnologias ambientais liberais que são orientadas para o mercado. As teorias sociológicas que enfatizam a importância da gestão, da governança e das dimensões culturais e institucionais da mudança ambiental têm importância crucial para o estabelecimento de uma agenda realista das ecomodernidades alternativas.

Ressalta-se que a ME está caminhando para além da ênfase na inovação ecotecnológica e considerando também estudos complementares sobre o papel dos consumidores. Como resultado, a ME na sua formulação atual, preocupa-se com o "esverdeamento" tanto da produção quanto do consumo.

\subsubsection{A orientação à montante dos debates de tecnologia ambiental}

Para alguns autores da ME, a inovação sociotécnica tem sido o foco principal da ME desde os primeiros avanços observados durante os anos 1980. Em parte como uma resposta crítica à perspectiva romântica do "pequeno é bonito" que formulou uma versão inicial da ME baseada em inovações ambiciosas e em princípios como a modificação genética e os avançados de informação e de tecnologias de comunicação. 
Apesar de suas diferenças em relação ao papel da tecnologia no equacionamento dos danos ecológicos, as abordagens conceituais sustentaram que os sistemas sociais e seus desempenhos ambientais são moldados pela tecnologia de forma fundamental e decisiva.

A proeminência da inovação tecnológica e seu impacto na sociedade no âmbito da ME gerou alguma sobreposição com as teorias econômicas de inovação predominantes, bem como com as perspectivas comuns na sociologia da ciência e da tecnologia (GEELS, 2005). Embora esta ênfase tecnológica tenha sido uma característica relativamente consistente da ME, as formas pelas quais os processos de inovação foram conceituados variaram ao longo do tempo e os pesquisadores empregaram diferentes termos e conceitos.

Nos períodos iniciais, que se estendeu até o início dos anos 1990, o debate priorizava a substituição de equipamentos da tecnologia de fim de tubo como filtros, e purificadores, por tecnologias preventivas e processos mais integrados. Tais estudos sobre tecnologias limpas continuam a constituir uma faceta reconhecível e indispensável no âmbito das idéias centrais da ME.

A busca por tecnologias ambientais preventivas, bem como os compromissos assumidos com a nova política de poluição identificada por Weale (1992), não se limitaram às empresas ou às instalações individuais de produção. Colaborações entre empresas com base em técnicas de ecologia industrial, incluindo trocas de subprodutos e de resíduos, também se tornaram cada vez mais comuns em algumas aplicações de manufaturas.

Observa-se também que em outras áreas, está sendo utilizada a gestão verde ou integrada da cadeia de suprimentos para melhorar a articulação das relações verticais entre as empresas colaboradoras. Por exemplo, os grandes atores do setor varejista de alimentos têm demonstrado capacidade de utilizar eficazmente as empresas colaboradoras com o objetivo de sistematizar a gestão ambiental na totalidade da extensão da cadeia de abastecimento.

Nestes estudos das dimensões organizacionais da ecologia industrial, a atenção sobre as relações hierárquicas de poder e interações entre empresas é complementada por foco especial nas relações horizontais (e espaciais) entre as empresas participantes que estão inseridas em diferentes sistemas de produção. A atenção da ecologia industrial de forma geral continua fortemente centrada na mensuração científica dos fluxos de materiais no interior da esfera de produção.

De acordo com Spaargaren e Cohen (2010), como o estudo das transições sociotecnológicas sustentáveis tem se expandido, a ênfase voltou para a gestão de multiníveis e processos multi-atores de ME. A série dos chamados estudos de transição serve como uma ilustração desta transição para uma análise social mais ampla da mudança tecnológica. Neste trabalho, o papel de longo alcance da inovação ainda é bastante 
evidente, mas o foco na melhoria tecnológica é geralmente combinado com análises das dimensões institucionais da mudança ambiental.

De acordo os autores, pesquisas recentes consideram diferentes setores da sociedade (energia, agricultura, habitação) e procuram identificar padrões não lineares de mudanças que poderia incentivar processos de transição para o desenvolvimento sustentável. Perguntas-chave dizem respeito a como alguns nichos baseados em inovação podem começar a criar possibilidades para mudanças do sistema, com o objetivo de proporcionar o surgimento de regimes mais sustentáveis para, por exemplo, a geração de energia ou a produção de alimentos.

Os estudiosos também têm procurado identificar os fatores de grande escala que podem facilitar ou dificultar transições de regime. Transformações no sentido de fornecimento de energia livre de carbono tem se tornado um dos campos mais ativos para a aplicação da perspectiva da ME.

Com base nesta visão geral de estudos da ME sobre tecnologia ambiental e inovações sociotécnicas pode-se identificar diferentes tendências que vêm ocorrendo ao longo das últimas décadas. Em primeiro lugar, houve durante este tempo, concordância que a mudança ocorreu longe da mitigação e as tecnologias de fim-de-tubo puderam ser implementadas sem alterar as estruturas organizacionais ou cadeias produtivas. Nos últimos anos temos visto o surgimento de estratégias proativas, mais preventivas e que implicam reestruturação dos modos existentes de consumo e de produção (SPAARGAREN E COHEN, 2010).

Em segundo lugar, as dimensões institucionais e gerenciais das mudanças induzidas pela tecnologia, gradualmente têm atribuído um papel mais importante nas análises de processos de eco-transição. Investigações lineares e orientadas para um único ator que se concentra no nível político nacional estão sendo suplantadas por estudos sistêmicos, multiatores, que consideram diferentes níveis de escala e as interações que ocorrem entre eles.

Desde o final da década de 1990, uma terceira tendência importante surgiu desafiando noções existentes de tecnologia ambiental que focam sua ênfase contínua sobre os fornecedores e sistemas tecnológicos, por exemplo, sobre as atividades a montante. Para Spaargaren (2003), os atores a jusante das cadeias de produção e de consumo, os grupos de consumidores, em particular, têm sido negligenciados, ou pelo menos subestimados, pelos cientistas e pelos formuladores de política, como orientadores importantes da mudança ambiental.

Com o obetivo de compensar o descaso do foco no consumidor e para complementar o atual conhecimento sobre as transições eco-tecnológicas, estudos recentes têm se concentrado nos padrões de vida de usuários finais. Para desenvolver essa 
perspectiva sobre a vida cotidiana de consumidores e tecnologia, uma rede internacional de pesquisa foi criada na Universidade de Lancaster, durante a década de 1990.

De acordo Spaargaren (2003), as pesquisas realizadas em infraestruturas do consumo foram importantes para o avanço da ME e para a construção de pontes com o objetivo de cobrir as lacunas existentes entre as abordagens das transições tecnológicas focadas nos produtores e nos consumidores. Pesquisadores sistematicamente têm desenvolvido vários conceitos que focam estudos de transição contemporâneos e têm avaliado a sua importância para a análise de tecnologias da vida cotidiana.

Ao colocar a transição sociotécnica das práticas sociais comuns no centro das discussões, estes estudos emergentes já ajudaram a criar uma perspectiva de consumo para o campo de estudos de transição e para reforçar a mudança do foco da produção para o consumo.

\subsubsection{Mudança do foco da produção para o consumo}

O foco central da ME está sobre as cadeias ou os ciclos de produção e de consumo e isso implica, pelo menos no sentido conceitual estrito, que os consumidores, ou outros utilizadores finais, estão incluídos na questão. Apesar deste reconhecimento tácito da relevância do consumo, a prática tem sido bastante diferente.

A tendência de longa data na ciência e na política ambiental tem sido a de ignorar o consumo e seus efeitos adversos. O principal argumento dos políticos para negligenciar o consumo tem se baseado na alegação de que é muito difícil e ineficiente buscar mudanças no comportamento dos consumidores enquanto que as estratégias destinadas aos produtores asseguram maiores chances de sucesso efetivo.

Os processos de produção de grandes empresas industriais têm sido tipicamente vistos como mais previsível e controlável do que os estilos de vida diversos e muitas vezes contraditórios de consumidores individuais. As iniciativas políticas para consumo sustentável têm se restringido aos esforços para melhorar a sustentabilidade das estruturas de produção e de distribuição, para que essas mudanças conscientizem também os consumidores (Spaargaren e Cohen, 2010).

Ressalta-se que nos poucos casos nos quais as decisões políticas têm procurado se envolver com o consumo diretamente, tendem a fazê-lo por meio de intervenções com base em informação pública e educação. Campanhas de marketing social têm enfatizado a importância da conservação da energia residencial e da água, por exemplo, incentivado o uso de sacolas de papel em vez de suas alternativas de plástico, e promovendo o transporte público (e bicicletas) como substitutos de automóveis particulares. 
No âmbito dos estudos realizados na ME, uma terceira estratégia que inclui o consumo é sugerida para ocupar o espaço entre as abordagens sistêmica e individualista. Estratégias para "esverdear" o consumo, sem a participação direta dos consumidores são consideradas inadequadas porque a redefinição eficaz dos sistemas de produção requer a participação e o compromisso dos consumidores finais.

As iniciativas que tentam contorná-los frequentemente resultam ineficazes porque as inovações de sustentabilidade não combinam com as práticas de consumo existentes. Além disso, os programas que simplesmente transmitem informações sobre produtos verdes ou conselhos para os consumidores sobre os impactos negativos de suas ações, acabarão por revelarem-se insuficientes para motivar alterações consequentes.

Essas diretivas devem ser combinadas com alternativas atraentes que estão dentro da compreensão realista dos consumidores. Em outras palavras, produtos e serviços ecologicamente sustentáveis devem se encaixar nas complexas dinâmicas do estilo de vida cotidiano e familiar.

Neste contexto, os consumidores podem ser transformados em agentes de mudança, sem a necessidade do uso de estratégias individualistas. Tal como os debates sobre tecnologia ambiental, as discussões sobre o consumo sustentável tem sido ao longo do tempo, caracterizada por divisões científicas sociais habituais. Atualmente, devido à ativa consideração desse problema ainda ser relativamente nova, os estudiosos ainda não elaboraram plenamente as respectivas abordagens e os livros publicados até o momento, demonstram diversidade teórica e empírica considerável.

No entanto, deixando-se de lado as abordagens individualistas mais comumente associadas com a economia e a psicologia social, o diferente entendimento contextual do consumo sustentável que surge pode ser subdividido em três grandes grupos (SPAARGAREN E COHEN, 2010)

Primeiro, identifica-se um conjunto de estudos que constitui a base para a escola de pensamento sobre o consumo sustentável e está focada nas redes que fornecem para os domicílios, a energia, a água, a eletricidade e outros serviços básicos. Embora o foco seja os fluxos ambientais habituais, esta pesquisa tem pouca semelhança com o trabalho sobre a conservação doméstica que atingiu o seu apogeu nas décadas de 1970 e 1980.

O uso prudente da energia e a separação de resíduos pertencem à primeira geração de comportamentos ambientais domésticos que se tornaram largamente aceitos e normalizados pela maioria das pessoas nos países ricos. Estudos contemporâneos sobre infraestruturas do consumo lidam com novas questões que ganharam destaque na Europa durante a década de 1980, devido à privatização e a liberalização dos serviços públicos (JACKSON, 1996). 
Tais pesquisadores focam na diferenciação e na fragmentação das redes de fornecedores, na falta de transparência e de comunicação entre fornecedores e consumidores domésticos, na mudança das relações de poder entre os atores de ambos os lados da mensuração da utilidade, e em novas formas de serviço de fornecimento conjunto e de auto fornecimento.

Em segundo lugar, os cientistas políticos e outros cientistas sociais começaram a identificar novas expressões de consumismo político incorporado em campanhas para "esverdear" as cadeias globais de produção e de consumo. O objetivo desses esforços é a elaboração de novos papéis para os consumidores que lhes permitam utilizar as suas práticas de compra como uma fonte de poder para promover transições sustentáveis.

A noção de inversão da cadeia é característica importante para a perspectiva do consumismo político. Para compreender melhor as complexas dinâmicas que regem as redes e as cadeias de produção e de consumo, a influência dos cidadãos-consumidores organizados é considerada o principal ponto de partida da análise (SPAARGAREN E COHEN, 2010).

Os defensores dessa perspectiva argumentam que sob certas circunstâncias, os valores políticos e éticos dos consumidores podem se tornar orientadores importantes da ME no que diz respeito aos processos de produção e de consumo. A determinação de como organizar mais eficazmente esta atividade proporciona o foco principal para a pesquisa empírica realizada por acadêmicos associados a essa escola de pensamento. Ressalta-se que o trabalho de Michelletti (2003) tem se destacado na definição dessa agenda propondo novos modos de compromisso político e de engajamento.

E essas atividades são uma alternativa para os tipos tradicionais de engajamento político e diminuem as barreiras para que essa questão possa ser incluída na política. As pessoas comuns podem usar seu poder de compra de inúmeras maneiras e normalmente não requerem treinamento especial, competência burocrática, filiação partidária ou a elaboração de logística institucional. Consumismo político, de acordo com os autores, é uma forma de subpolítica que é acessível, volátil, voluntária e mais próxima da vida cotidiana do que o repertório habitual de práticas que constituem a participação política mais convencional.

O uso organizado de fluxos de informações ambientais que fluem por meio das cadeias de produção e de consumo pode ser muito útil para fins da ME. O aumento maciço de programas de rotulagem e de certificação ao longo dos últimos anos, especialmente na União Européia e até mesmo em países em desenvolvimento, é prova de que uma nova geração de instrumentos está emergindo com o potencial de aumentar o compromisso e o envolvimento dos consumidores na mudança ambiental (BOSTROM, 2008). 
Oosterveer et al (2007) destacou a importância da rotulagem ambiental e a forma como essas ferramentas podem ser interpretadas como uma resposta para os desafios da construção de confiança do consumidor em relação às cadeias de aprovisionamento globais. Os grupos de consumidores e organizações não governamentais de meio ambiente (ENGOs) têm um papel crucial para desempenhar na mobilização dos consumidores para que se tornem agentes eficazes de consumismo político.

Apoiando os programas de rotulagem ambiental e outros programas de auditoria, os produtores podem promover eficazmente e restabelecer a confiança entre os consumidores. Esta mobilização de ações de base pode colocar pressão sobre os fornecedores na extremidade das cadeias de produção-consumo a montante, sem a necessidade de uma regulamentação oficial ou participação governamental. Também em nível internacional, há indicações de que ENGOs podem ser facilitadores eficazes de confiança até mesmo entre os atores distantes (WOODS e SCHNEIDER, 2006).

Para desenvolver intervenções políticas mais sofisticadas para "esverdear" estas rotinas diárias é necessário reconhecer e desconstruir as interdependências entre as tecnologias e as normas que regem as práticas sociais. Somente reconhecendo as profundas conexões que ligam, por exemplo, o aquecimento e as tecnologias de refrigeração com as noções do que constitui um clima interno saudável, é que se começará a identificar as possibilidades de alternativas mais sustentáveis em vigor.

Ressalta-se que as transições de sustentabilidade na vida cotidiana implicam a coevolução da tecnologia com as normas e as práticas sociais. De acordo com Giddens (1991a) não podemos compreender a estruturação das práticas sociais, sem o conhecimento dos fluxos constantes de tecnologias ambientais, de produtos e de normas que surgiram e reformularam nossas vidas diárias a partir de meados da década de 1980 . Para o autor, o "esverdeamento" das práticas sociais cotidianas está acontecendo diante dos nossos olhos e essa proximidade faz com que estes avanços se tornem mais perceptíveis, especialmente em comparação com os processos globais paralelos e interdependentes que estão ocorrendo em todos os setores.

Para Spaargaren e Cohen (2010), embora cada uma destas três abordagens possua ênfase específica própria, não há sobreposição significativa no que diz respeito às suas raízes teóricas e orientações de pesquisa. As várias escolas que estudam o consumo sustentável também compartilham um interesse comum em conjugação das investigações de inovações sócio-técnicas com as dinâmicas institucionais e sociais de consumo e de produção.

Para os autores, pesquisadores que trabalham nestas áreas se recusam assinar as separações do padrão científico - social entre os níveis micro e macro de análise, mas em 
vez disso procuram identificar as interações e as interdependências entre os processos de trabalho em diferentes escalas desde a escala global até a escala local.

Fazem contribuições específicas para a compreensão dos papéis que os atores humanos desempenham na condição de agentes de mudança nas transições da sociedade na direção de práticas de consumo, estilos de vida e política mais sustentáveis.

\subsubsection{O processo de marrakech}

As dimensões da sustentabilidade do consumo foram conceituadas em termos políticos, pela primeira vez, em 1992, na Conferência do Rio de Janeiro. A Agenda 21, considerada o plano de ação da Conferência, afirma que "todos os países devem se esforçar para promover padrões de consumo sustentáveis" e encoraja os países desenvolvidos a assumir a responsabilidade para liderar esta mudança.

Este novo foco no consumo, em oposição à ênfase tradicional na produção, gerou uma poderosa onda de controvérsia que foi impulsionada pela reação negativa dos EUA e de vários outros países desenvolvidos. Após a Conferência do Rio, o Conselho de Ministros dos países Nórdicos e a OCDE desempenharam papel construtivo para contornar controvérsias e aprofundar a essência conceitual de um programa nascente de política de consumo sustentável.

Durante este período, a principal abordagem entre as instituições governamentais, era redefinir o consumo sustentável em termos de estratégias mais familiares e menos voláteis e inclui-lo no âmbito da produção mais limpa, da análise do ciclo de vida e da gestão integrada de produtos. A insatisfação com essa abordagem conceitual, especialmente entre os países em desenvolvimento e algumas ONGs ambientalistas, deu às questões de consumo um destaque visível na Conferência de Joanesburgo em 2002.

Isto gerou um compromisso de produzir um programa sobre consumo e produção sustentáveis sob os auspícios do PNUMA e do Departamento das Nações Unidas para Assuntos Econômicos e Sociais (UNDESA).

A formulação deste Programa, que veio a ser conhecido como o Processo de Marrakech (Figura 1), teve início em 2003, com uma sequência de reuniões internacionais em Marrocos e dois anos mais tarde na Costa Rica. Em paralelo, uma série de diálogos regionais de interessados foi iniciado na América Latina e no Caribe, na África, na União Européia e nos países da Ásia-Pacífico para incluirem questões de relevância local (CLIATH, 2007).

Sob a coordenação do PNUMA e da UNDESA, o Processo contou também com a participação de governos nacionais, agências de desenvolvimento, setor privado, sociedade civil e outros atores. 
A adesão ao Processo de Marrakesh criou a obrigação de ser desenvolvido um programa de atividades que levasse à elaboração de um Plano de Ação. Para subsidiar tal demanda, O PNUMA e seus parceiros criaram o "10-Year Framework of Programmes on SCP - 10YFP", que incluiu manuais metodológicos, a criação de forças-tarefas e de grupos de trabalho que buscaram identificar as experiências mais avançadas de produção e consumo sustentáveis nos países para poder disseminá-las.

\section{Figura 1 Mecanismos do processo de Marrakesh}

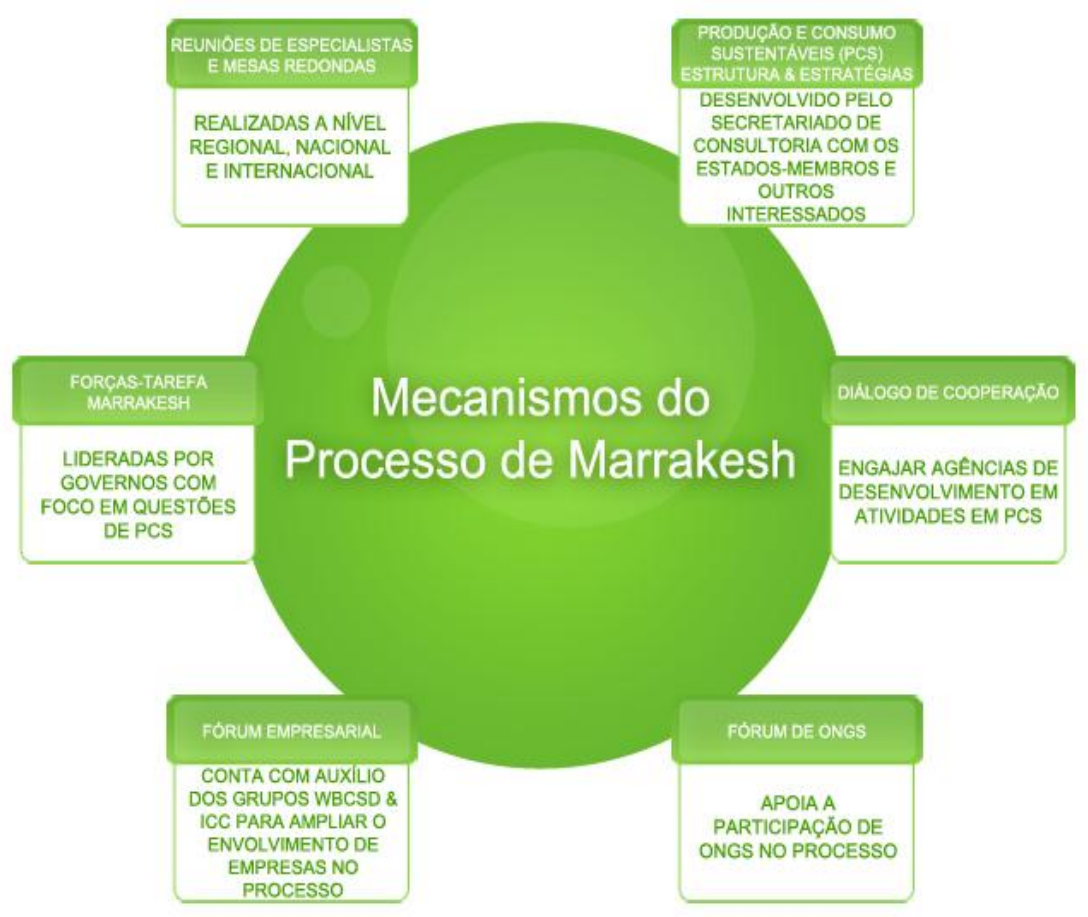

Fonte: http://www.unep.fr/scp/marrakech/pdf/FAQ-UNEP-marrakech-brochure FINAL.pdf

Uma característica importante do Processo de Marrakech foi a tensão que existiu a respeito de como o conceito de consumo sustentável deveria ser definido e desenvolvido. Praticamente todos os proponentes alegaram que, como o desenvolvimento sustentável, os objetivos do consumo sustentável eram muito amplos para justificar uma definição rigorosa e os esforços para fazê-lo, necessariamente, limitariam a sua eficácia.

Para Tukker et al. (2006), essa ambiguidade proposital permitiu que as pessoas com interesses divergentes se reunissem em torno da mesma mesa e gerassem uma considerável confusão sobre os termos do debate e do conteúdo da discussão.

Como aplicado nos países desenvolvidos, o consumo sustentável geralmente implica em reduções no uso da energia e de materiais e, consequentemente, redução da pegada ecológica per capita do consumidor. Para os países em desenvolvimento e algumas ONGs ambientalistas, a noção de consumo sustentável objetiva chamar a atenção para um 
subconsumo crônico e persistente. Por isso, o objetivo é fornecer os recursos necessários para permitir que a maioria da população do planeta aumente o consumo de forma que possam satisfazer de forma mais adequada suas necessidades básicas.

A falta de acordo sobre os parâmetros de definição e objetivos políticos, contudo, não foi o único fator que tem limitado o avanço da agenda internacional sobre o consumo sustentável. O sistema da ONU é manifestamente hierárquico e o PNUMA não desfruta de um nível muito alto de estatura entre os seus pares.

O problema é agravado por dificuldades orçamentárias crônicas, e o fato de que, além do PNUMA, praticamente todas as organizações constituintes da ONU são cobradas de uma forma ou de outra por facilitar objetivos habituais relacionados com o crescimento econômico.

Para Spaargaren e Cohen (2010), a boa gestão ambiental parece ficar no caminho desse objetivo e quaisquer esforços que possam ser interpretados como reduções do consumo são vistos como absolutamente incompatíveis com os objetivos gerais do sistema internacional. Sem o apoio de outros atores-chave, o PNUMA tem sido forçado a construir as suas iniciativas em torno do voluntarismo de governos nacionais simpáticos a causa.

Esses projetos têm-se centrado na preparação de relatórios, manuais de treinamento e outros materiais informativos e educativos. Temas como análise do ciclo de vida, compras governamentais sustentáveis e sistemas produto-serviço foram abordagens para esses projetos especialmente favorecidos.

De forma geral, pode-se afirmar que no que se refere às políticas internacionais de consumo e de produção sustentáveis, pode-se concluir que as políticas sistemáticas referentes ao estilo de vida e ao consumo ainda não são visíveis em nível global, embora exista uma quantidade considerável de atividade organizacional que ocorre atualmente fora da vista do público.

Como nos tempos iniciais da ME voltados para a produção, há uma necessidade urgente de modernização política para inventar novos arranjos políticos e formas inovadoras de governança para superar os problemas da falha do Estado no que diz respeito às políticas nacionais de consumo.

O compromisso de negociar uma estratégia comum no "esverdeamento" do consumo certamente representa um primeiro passo importante, mas há atualmente, menos acordo entre os atores da divisão Norte-Sul sobre o consumo do que há sobre a ME da produção em que a tarefa tem sido prosseguida em grande parte como um exercício técnico. Esta situação é em grande parte devido às controvérsias políticas e econômicas não resolvidas sobre a necessidade e eficácia de políticas específicas para facilitar o consumo sustentável. 


\subsubsection{A necessidade de modernização da ME}

A ênfase original da ME na produção mais limpa e na inovação tecnológica à montante do processo produtivo está sendo complementada por um foco especial sobre o consumo e as tecnologias relacionadas com a vida cotidiana. As consequências para a ME tem sido o desenvolvimento de eco-racionalidades de consumo e de estilos de vida que são bastante diferentes das eco-racionalidades que regem as políticas baseadas nas empresas e nos produtores.

Para Featherstone (1991), a ME deve se renovar para confrontar e acolher os dois desafios mais importantes que surgiram nas ciências sociais ao longo dos últimos 20 anos: a globalização do consumo e da produção e o retorno consumista.

Torna-se necessário modernizar a ME porque estes dois avanços alteraram fundamentalmente o caráter de cadeias de produção, de consumo e de redes. As principais instituições responsáveis pela gestão do consumo e da produção, em condições de "modernidade simples", desde o fim da Segunda Guerra Mundial até meados dos anos 1980, foram radicalmente reformadas e ganharam uma nova dinâmica na fase atual de "modernidade reflexiva".

Para Spaargaren e Cohen (2010), como uma teoria social, a ME tem sido forçada a (co) evoluir em conjunto com os seus principais objetos de interesse teórico e empírico: as redes de produção e de consumo e as cadeias produtivas. A ME, de fato, tem contribuído para esse processo de reforma, salientando a necessidade de incluir eco-racionalidades nas regras que regem a organização da produção e do consumo. Quando interpretado ao longo destas linhas, a renovação teórica é um sinal de força, de uma teoria que está sobrevivendo e que é relevante porque os atores sociais a estão submetendo ao uso freqüente, à discussão e à adaptação.

As ênfases flexíveis no âmbito da ME deram origem aos debates teóricos na comunidade de estudiosos que trabalham com a teoria. Com relação ao impacto da globalização, especialmente o papel dos Estados-nação, e seu poder aparentemente diminuido para influenciar o comportamento dos agentes do mercado e as instituições da sociedade civil, tornou-se um tema de debate frequente.

Em relação à volta do consumismo, há um esforço em evolução nas ciências e na política ambiental, para entender o significado de uma orientação do consumidor. Apesar de haver consenso de que esta orientação do consumidor ganhou impulso nos últimos anos e está cada vez mais difundida, essa orientação não é necessariamente bem acolhida por todos os estudiosos da ME.

Huber (2004) defende um argumento explícito contra um foco a jusante sobre os usuários finais de produtos e serviços. O consumismo entendido como uma mudança 
inicada a partir de meados da década de 1980 a partir da concepção de políticas de sustentabilidade a montante está comprometendo a capacidade da ME de se concentrar sobre os impactos mais críticos do processo de decisão contemporâneo.

Quanto mais a pessoa é capaz de se envolver com cadeias e redes, mais eficazes serão as intervenções resultantes no que diz respeito à sustentabilidade. Para Huber (2004), os impactos ambientais advindos da fase do usuário final representam menos de $30 \%$ dos impactos totais e esta proporção relativamente baixa, não justifica os esforços para interferir ativamente com os consumidores.

Com base nesta observação, pode-se concluir que os debates tanto sobre a ME quanto no âmbito da ME não evoluem de forma linear com novas afirmações simplesmente, suplantando velhos argumentos. Por meio de processos de discussão contínua e de revisão, e reinterpretando textos clássicos, à luz dos novos desafios e de condições sociais, o campo de estudos da ME mantém a sua vitalidade e sob tais condições tem demonstrado uma capacidade de contribuir de forma eficaz para um futuro mais sustentável.

\subsection{Limitações da ME}

Desde a emergência da ME como uma noção, um conceito ou uma teoria, ela tem sido debatida com outras noções, conceitos ou teorias, no âmbito das ciências sociais ambientais. Tal debate intensificou-se a partir do início dos anos 1980, particularmente com os neomarxistas.

O debate com os neomarxistas e com outros cientistas sociais radicais centralizaram-se em torno da idéia de que a modernização ecológica nas suas dimensões normativa e analítica inclui uma trajetória reformista de mudança que não se dissocia dom modo capitalista de produção e de consumo. Para Redclift e Benton (1994), as recepções adversas provêm de estudiosos que acreditam que a ME, que redefinem como capitalismo sustentável, não será bem sucedida, especialmente por sua análise acrítica e conveniente com a responsabilidade do capitalismo na crise ambiental.

Outras críticas identificam a ME com a Teoria da Sociedade do Risco, desenvolvida por Ulrich Beck no final da década de 1980. Em outros casos, argumenta-se que a ME carece de um conjunto de postulados identificáveis e corentes, sugerindo que se poderia melhorá-la, se ela mesma fosse embasada em teorias mais abrangentes sobre o Estado (BUTTEL, 2000).

Torna-se um desafio, então, a elaboração de conceitos compartilhados para operacionalizar e ofercer uma representação mais concreta da emancipação da racionalidade da esfera ecológica da sua contra parte econômica, quer dizer, definir um 
conjunto básico de pressupostos e conceitos sobre os processos de produção e consumo ecologicamente racionais (OLIVIERI, 2009).

Aceitando esses desafios, Milanez e Buhrs (2007) têm proposto uma estrutura teórica com a finalidade de encontrar um sentido mais unitário nas diferentes clivagens existentes no inteior da ME. Essa proposta implica uma caracterização da ME que a identifica com a implementação da inovação preventiva nos sistemas de produção, seja nos processos quanto nos produtos, que produza simultaneamente benefícios ambientais e econômicos.

Em relação à prática da ME, Janicke (2010), destaca limites como: o crescimento econômico tende a neutralizar as melhorias ambientais se o crescimento da eco-eficiência permanecer no caráter incremental, se as inovações ambientais continuarem restritas a determinados nichos ecológicos e,se as soluções providas não tratarem das causas efetivas dos problemas ambientais.

A ME reconhece a resistência de prejudicadores da modernização, geralmente dotados de poderes que permitem a limitação do escopo e dos efeitos de uma política ambiental efetiva. Estes agentes podem não ser fortes o suficiente para oprevenir inovações ambientais políticas baseadas em conhecimento, mas quando se fala de implementação das políticas já existentes, a resistência do poder de base permanecee como um importante obstáculo.

Já, Harvey (1996) complementa essas limitações com certas noções de risco implícitas à teoria da ME. Segundo o autor, enquanto esta discussão apresenta a ME como uma possibilidade plausível de transformação das economias capitalistas, ela ainda pode ser utilizada como um discurso mentiroso e corrupto dotado de um único interesse, o de dominar os meios de poder econômico. Por meio desta abordagem, segundo Gibbs (2000), pode-se alcançar uma dominação global de recursos naturais por indústrias transnacionais, governos nacionais e grandes movimentos científicos em nome da sustentabilidade.

Outra limitação relacionada com a ME, de acordo com York e Rosa (2003) é a visão predominantemente eurocêntrica em função de as raízes teóricas e empíricas desta teoria terem sido extraídas de países do norte europeu, cujos padrões de vida são muito distintos daqueles vivenciados por grande parte das outras nações do planeta.

Adiciona-se a excessiva ênfase sobre as indústrias transformativas, a reocupação predominante com fatores de eficiência e de controles de poluição ao invés das questões mais importantes como o consumo de recursos naturais e seus respectivos impactos ambientais, a abordagem não crítica sobre as potencialidades inovadoras do capitalismo moderno, e o fato de inumeras questões fundamentais ainda não respondidas sobre os fenômenos da ME não serem contemplados na estruturação da teoria da ME. 
Além das limitações acima referidas, para Milanez (2009), a ME tem uma visão utilitarista do meio ambiente, que é apenas considerado como matéria prima para as atividades econômicas e concentra-se apenas em aspectos econômicos e ambientais e ignora as questões sociaias. Ainda de acordo com o autor, a ME caracteriza-se por uma determinada ingenuidade tecnológica, uma vez que ainda acredita que o processo inovativo seria suficiente para solucionar os desafios ambientais.

Sonnenfeld (2000) ressalta que uma das limitações da ME está relacionada com a aplicabilidade dessa teoria nos países recentemente industrializados e diz respeito à desmaterialização. O autor afirma que a produção está se supermaterializando no Hemisfério Sul e se desmaterializando no Hemisfério Norte e que a ME nas sociedades industriais modernas pode se tornar dependente do aumento da materialização em outras regiões do planeta.

Ainda de acordo com Sonnenfeld (2000), outra limitação foca a aplicação da ME nas pequenas e médias empresas que desempenham papel importante nas economias dos países em desenvolvimento no que se refere à criação de empregos e ao atendimento da demanda doméstica. Em geral, essas empresas se utilizam de antigas tecnologias que não protegem o meio ambiente adequadamente e no âmbito da ME seria necessário substituílas por tecnologias mais modernas, mais caras e cuja aquisição poderá causar desemprego com elevados custos sociais para esses países.

De forma geral, apesar da existência de limitaçõpes consideráveis, a aplicação da ME por determinados países e determinados setores da economia, pode contribuir para que a questão ambiental seja considerada simultaneamente com a questão econômica e trazer benefícios para as populações envolvidas. 


\section{Capítulo 3 - A MODERNIZAÇÃo ECOLÓGICA E A ROTULAGEM AMBIENTAL}

\subsection{Introdução}

O conceito da ME surgiu como uma resposta às idéias defendidas pelo neomarxismo, à desmodernização, à desindustrialização ou às teorias da contra-produtividade. Essas teorias defendiam que a proteção e a reestruturação ambiental só poderiam ser alcançadas por meio de mudanças radicais nos sistemas de produção e de consumo que formam a estrutura central do capitalismo (MOL E SPAARGAREN, 2000).

$\mathrm{Na}$ prática, a capacidade dessas teorias e normas radicais de contribuirem para 0 redesign das sociedades capitalistas modernas por meio de linhas ecologicamente benignas produziu pouco impacto na definição de política e gestão ambiental.

É improvável que o radicalismo estabeleça a base normativa para as políticas públicas, porque exige uma mudança muito grande na totalidade dos sistemas existentes. $O$ conceito de ME proporciona uma abordagem alternativa em função do seu caráter incremental, simplista e confiante na eficácia da ciência e de seus instrumentos.

As primeiras iniciativas que foram tomadas na direção da aplicação prática dos pressupostos da ME tiveram lugar na Alemanha e uma delas foi a criação de um programa de rotulagem ambiental denominado "Blue Angel' que certificaria as empresas que diminuíssem suas emissões atmosféricas e resíduos. A idéia era contribuir para a diminuição da poluição e ao mesmo tempo criar um nicho de mercado onde esses produtos certificados fossem comercializados. A rotulagem ambiental começou a ser utilizada como um instrumento da ME.

A implementação de programas de rotulagem ambiental na União Européia, ainda na década de 1970, sugeriu que os tomadores de decisão política e os representantes do setor privado procurassem harmonizar a proteção ambiental com as considerações econômicas, em conformidade com os princípios da ME (COHEN, 2006).

Os programas de rotulagem da União Européia representam uma parte da trajetória normativa na direção da reforma do meio ambiente no âmbito do mercado. A busca pela eficiência ecológica e pela ecologização da produção e do consumo bem como o envolvimento dos agentes econômicos pela ciência e pela tecnologia são elementos-chave para a caracterização e para a evolução dos programas de rotulagem.

Para Williams (2004), os programas de rotulagem representam uma manifestação da ME que resulta da harmonização de forças sociais da sociedade de consumo com a sustentabilidade ambiental e propiciam um impulso para o consumo sustentável. 
Ressalta-se que na Agenda 21, estabelecida na Conferência para o Meio Ambiente e o Desenvolvimento, em 1992, no Rio de Janeiro, foram feitas recomendações para que os governos, em cooperação com a indústria e com outros grupos relevantes estimulassem a expansão da rotulagem ambiental e de outros programas de informação de produtos relacionados com o meio ambiente para que os consumidores pudessem realizar suas escolhas com informação.

A rotulagem ambiental é coerente com o princípio básico da ME que estabelece que a inovação tecnológica e o desenvolvimento industrial contínuo se constituem na melhor forma de enfrentar as crises ecológicas. No que diz respeito à rotulagem ambiental, presume-se que os rótulos possam ajudar a acelerar a difusão dos avanços tecnológicos de produtos e ao mesmo tempo incentivar a inovação ambiental para que os critérios exigidos pelos programas de rotulagem sejam alcançados.

Sua finalidade não é garantir que um problema ambiental seja completamente erradicado, mas garantir que o agravamento causado por processos de produção atuais sejam minimizados. A rotulagem ambiental representa tanto a aplicação tecnológica quanto os benefícios comerciais inerentes ao modernismo ecológico. Isso reforça a idéia da repartição dos ganhos advindos do processo para todos os participantes (CLIATH, 2007).

Considerando-se a lógica da ME, a rotulagem ambiental lida geralmente, de forma mais efetiva com as questões dos padrões de consumo do que com as questões dos níveis de consumo. No âmbito do debate acadêmico sobre a ME, vários críticos têm expressado suas preocupações em relação ao tema. Essas críticas lançam luz sobre as limitações da rotulagem como instrumento de proteção ambiental.

Na lógica política neomarxista, a produção econômica está em conflito fundamental com os limites ecológicos. Na reestruturação ecológica com base na $\mathrm{ME}$, as crises do capitalismo não são totalmente resolvidas, mas reconfiguradas em novas relações (Li e Hersh, 2002).

O capitalismo tenta constantemente resolver as crises, por meio da reorganização da sociedade, sem efetivamente, se aproximar das causas. Os programas de rotulagem ambiental são emblemáticos de uma reconstituição passiva das relações dentro do mercado. Em vez da reestruturação e da reavaliação da interação da sociedade com o meio ambiente, os programas de rotulagem escondem as relações de exploração existentes no mercado.

Isso inclui os desequilíbrios de poder entre consumidores e produtores, entre os grandes produtores e os pequenos produtores, e entre a indústria e os governos. Para Hajer (1995), o discurso ecológico-modernista diminui o impulso político das reformas ambientais e prejudica a capacidade da expansão econômica, do crescimento do consumo e das mudanças tecnológicas de capital intensivo de garantir um meio ambiente sustentável. 
A União Européia, para alguns autores, ao adotar esses programas de rotulagem como parte crítica de uma estratégia ambiental maior, comprometeu a sua própria capacidade de lidar com a crise ambiental e cumprir as promessas que fez aos cidadãos europeus em matéria de proteção ambiental.

No âmbito do mercado o discurso da crise ambiental gerou a seguinte questão: Como a sociedade econômica pode se adaptar à capacidade ecológica limitada do planeta, com base no consumo? A resposta do mercado: consumo sustentável.

O consumo sustentável é definido, de forma geral, como o uso de bens e serviços que preenchem as necessidades básicas das pessoas e que imprimem uma melhor qualidade de vida para as populações, ao mesmo tempo em que minimiza o uso de recursos naturais, de materiais tóxicos e diminui as emissões de resíduos e de poluentes ao longo do ciclo de vida dos produtos, de forma a não comprometer as necessidades das gerações futuras (UNDESA, 1999).

Este conceito reflete uma tentativa de estabelecer formas de mudanças pelas quais as sociedades capitalistas modernas respondem aos seus problemas eco-políticos. A abordagem política e prática dominante da teorização ambiental da União Européia são a ME. Para Huber (1986), a teoria sugere que o caminho no sentido da hiper-modernidade e da superindustrialização não é apenas inevitável, mas geralmente uma estratégia desejável para superar a atual crise ambiental.

As economias de mercado são compatíveis com o progresso na direção da produção ambientalmente saudável. Consequentemente, os impactos ecológicos podem ser minimizados na medida em que os sistemas de produção sejam reorganizados em linhas ecologicamente racionais. A indústria, defendida por Mol (2000), e impulsionada pela modernização, torna-se mais ecologicamente racional por meio da ponderação dos custos e dos benefícios da degradação ambiental. Além da internalização dos impactos ambientais que geram um cenário de ganha-ganha (win-win).

Para permitir que esse processo aconteça, a natureza precisa ser uma commodity e, em vez de perseguir uma abordagem de comando e controle e imposição de regras rígidas a partir de uma burocracia centralizada, os governos devem orientar os agentes privados na direção de práticas ecologicamente corretas. Esta abordagem baseada em incentivos visa criar flexibilidade, e ao mesmo tempo incorporar partes específicas em um processo participativo.

A ME devido ao seu caráter incremental e acomodativo, foi gradualmente adotada como uma proposição normativa e um programa político. Por conseguinte e de acordo com Mol (2001), tem-se traduzido em políticas públicas e práticas de gestão. Um dos exemplos mais claros de implementação prática da ME são os chamados novos instrumentos de política ambiental da União Européia, dentro dos quais se destacam os programas de 
rotulagem ambiental. Dessa forma a rotulagem ambiental é considerada como um instrumento efetivo da ME.

De acordo com os modernistas ecológicos, os problemas ambientais nas sociedades avançadas são em grande parte devido aos processos de produção ineficientes e só pode ser resolvida por meio de novas tecnologias no âmbito de uma reforma ambiental gradual lenta e constante. $O$ argumento implica que, se os produtos são sustentáveis, os consumidores vão consumir de forma mais sustentável.

A crescente influência da economia neoliberal, notadamente na década de 1980 e suas soluções de mercado para a gestão ambiental se intensificou em função do aumento de um fenômeno igualmente importante: a sociedade de consumo. As raízes da sociedade de consumo e o consumismo podem de certa forma, ser vinculados aos princípios básicos do capitalismo estabelecidos na "Riqueza das Nações", de Adam Smith. O autor descreve o consumo como o único fim e o propósito de toda a produção. O autor afirmava que o bemestar do produtor devia ser atendido apenas na medida em que promovia o bem estar do consumidor.

$\mathrm{Na}$ sociedade de consumo, os gastos do consumidor refletem as preocupações da sociedade com a identidade, com o estilo de vida e com a posição social baseada no consumo de bens e serviços que conferem (VEBLEN, 1953).

Os indivíduos consomem para fins sociais específicos e o aumento do consumo não se limita apenas responder às necessidades fundamentais e nem se comporta de forma racional e utilitarista, embora as necessidades sejam criadas pelos consumidores e para os consumidores. Os fins sociais e as relações sociais por meio das quais as mercadorias são produzidas são disfarçados na mercadoria por meio do mercado (BAUDRILLARD, 1998).

Observa-se que a maior parte dos estudos da ME foca o lado produtivo da economia e, no entanto, a perspectiva dessa teoria também pode ser relevante para o consumo. Podese dizer que a maioria das iniciativas ambientais dirigidas para o consumo nas últimas décadas, nos países desenvolvidos, enfatiza uma visão moderna das questões ambientais e o desenvolvimento dos rótulos ambientais clássicos é um exemplo.

Quando a Alemanha criou o seu programa de rotulagem ambiental no final da década de 1970, a iniciativa pressupunha algum interesse dos consumidores e das empresas e uma visão geral dos problemas ambientais como sendo passíveis de solução; esquemas de tratamento de resíduos também tinham de confiar no interesse do consumidor e da cooperação. De forma geral, a preocupação ambiental com o consumo sugeria uma visão pragmática e anti-apocalíptica das questões ambientais (RUBIK e CHEER, 2008).

A ME, por defender o incrementalismo, que são pequenas mudanças positivas para um grande número de pessoas, indica que é possível responder ao desafio ambiental, mesmo levando-se em consideração as condições políticas e econômicas atuais e também 
indica uma forma de resolver, ou pelo menos reduzir os problemas ambientais que surgem, a partir de um grande número de pequenos atos individualizados. No âmbito dessa lógica, encontram-se os sistemas de informações ambientais sobre produtos (EPIS), como os programas de rotulagem ambiental.

Essa condição da sociedade capitalista é chamada de fetichismo da mercadoria. $\mathrm{Na}$ medida em que as relações sociais de produtos não se fazem visíveis, a percepção do consumidor constitui uma fetichização. $O$ valor que é concedido a uma mercadoria não é inerente ao material que a constitui, mas é equacionado pelas relações sociais por meio das quais foi produzido e consumido (MARX, 1974).

Em nenhum lugar isso é mais perceptível do que no mercado de alimentos. Como a produção de alimentos capitalista evoluiu concomitantemente com inovações tecnológicas e com melhores práticas de gestão, um complexo sistema de produção de alimentos surgiu. 0 sistema tornou-se cada vez mais eficiente e ofereceu aos consumidores uma excepcional variedade de comida a preços baixos nos países industrializados.

Do lado da oferta, emergiu instrincadas formas de complexos agro-industrial que mudavam constantemente sua relação com o ambiente sócio-econômico e natural. Para Fulponi (2007), o resultado foi um aumento dos monopólios, processadores de alimentos em grande escala, varejistas, bem como o aumento da distância da fazenda até a mesa do consumidor.

A moderna experiência do consumidor com a alimentação não tem contato com a produção, está perdida no complexo agro-idustrial, e caracterizada pela deficiência de conhecimento das condições de trabalho, da produção e também da composição dos ingredientes dos produtos (Adams, 1990). Mesmo assim, a transformação do sistema alimentar trouxe benefícios para os consumidores com relação a maior quantidade, melhor qualidade, segurança, variedade, conveniência e preços acessíveis.

Os consumidores da União Européia e de outros países desenvolvidos, adicionalmente, exigem para esses produtos, técnicas de produção e de processamento ambientalmente benignas, sustentáveis, evidências aceitáveis de sanidade animal, emissões atmosféricas e produção de resíduos controlados e conformidade com as normas laborais e sociais vigentes. Critérios e exigências que são geralmente conferidos por meio de programas de rotulagem ambiental (Fulponi 2007).

No contexto da ME, a noção de cidadania ecológica de Dobson, o conceito de cidadão consumidor de Spaargaren ou o conceito do consumismo político de Oosterveer, sugerem que os consumidores participem do processo de tomada de decisão política, garantindo que suas preocupações ambientais e sociais sejam colocadas em prática por meio do poder de compra. Poder esse, que pode ser exercido por meio de informações críveis e fidedgnas contidas nos rótulos ambientais. 
As recentes transformações da identidade e das expectativas dos consumidores foram impulsionadas em grande parte, pela politização do consumo e pelos problemas ambientais e de saúde que foram causados pela industrialização da agricultura.

$\mathrm{Na}$ década de 1990, a União Européia começou a responder a estes cidadãos consumidores elaborando projetos sustentáveis de produção e de consumo. Em 2008, a Comissão Europeia estabeleceu o Plano de Ação para a Produção e para o Consumo Sustentáveis, como parte integrante da sua estratégia de desenvolvimento sustentável.

Tal plano reforçou o compromisso da União Européia de enfrentar os desafios do desenvolvimento sustentável baseados em iniciativas e instrumentos em nível comunitário e internacional como o Processo de Marrakech das Nações Unidas (Comissão Europeia 2012).

O Plano de Ação tinha como objetivo melhorar o desempenho energético e ambiental dos produtos e facilitar a sua aceitação por parte dos consumidores. No centro do Plano de Ação estava a chamada estratégia dinâmica para um consumo mais inteligente e para melhores produtos e era baseada em uma série de medidas políticas e normas para todo o mercado interno europeu.

A abordagem se concentrou em produtos com potencial significativo de redução dos impactos ambientais. As medidas sustentáveis de produção e de consumo adotadas pela União Européia incluíram esquemas de auditoria e manejo ecológico, esquemas de rotulagem ambiental e do rótulo energético, diretivas e incentivos para o design sustentável, dentre outras e priorizaram o comportamento individual do consumidor para de forma indireta, alterar as condições de enquadramento do consumo (WOLFF E SCHÖNHERR (2010).

Nas últimas décadas, os EPIS foram implantados em toda a União Européia como um componente importante da estratégia do mercado europeu, no âmbito da aplicação da ME.

O comércio internacional liberal e os sistemas avançados de tecnologia e de logística combinados com uma nova ordem mundial de produção e com a internacionalização da divisão do trabalho, permitiram o livre fluxo de mercadorias com disponibilidade de uma grande variedade de bens de consumo. As cestas de mercado das pessoas nos mais distantes lugares da Terra estão cada vez mais semelhantes (ROSA, 2000).

Consumidores globais estão se deparando gradativamente, com opções semelhantes. O poder coletivo dos consumidores para influenciar os métodos de produção aumenta, na medida em que, os hábitos de consumo globalmente se homogenizam. Por meio de uma demanda consistente de produtos e de serviços com rótulo ambiental, os consumidores podem contribuir para novos arranjos produtivos globais ambientalmente mais sustentáveis. 
O impacto total da atividade antrópica no planeta é significativo e insustentável levando em consideração a atual taxa de consumo e de esgotamento de recursos naturais. Como consequência a deterioração ambiental global é alarmante. O homem destrói o meio ambiente com uma velocidade surpreendente e em um período de poucos séculos ameaça uma extraordinária variedade de espécies que levou bilhões de anos para ser produzida.

O sistema finito dentro do qual vivemos está sobrecarregado. As atividades econômicas e de produção e o ciclo de consumo devem ser drasticamente alterados e planejados para uma escala menor para que possamos cuidar de nossa sobrevivência. Nesse contexto, e como idéia central desta tese, a rotulagem ambiental torna-se um instrumento efetivo da ME que fortalece a gestão ambiental, e proporciona ganhos econômicos e ecológicos para as empresas e informa os consumidores sobre o desempenho ambiental de produtos.

O rótulo ambiental trata do exercício do direito à utilização dos recursos biológicos e da conservação da biodiversidade, da ME, da propriedade intelectual e dos ativos coletivos e comuns intangíveis globais. A proteção do meio ambiente e a ME dos padrões de produção e de consumo, por necessidade, se tornarão a nova meta a ser alcançada pela sociedade e pelo setor de negócios ao longo dos próximos anos e a rotulagem ambiental pode contribuir efetivamente para este processo (GUERRA, 2003).

\subsection{A rotulagem ambiental}

A rotulagem ambiental faz parte do processo no qual a proteção ao meio ambiente se converte em valor social. $O$ aumento da consciência ambiental nos últimos anos tem sido acompanhado por efeitos nos mercados consumidores de produtos e serviços. Estes efeitos têm se apresentado na direção de uma crescente demanda por informação, da parte dos consumidores, sobre os aspectos ambientais envolvidos na produção, fator que cada vez mais tem influenciado sua decisão de compra (BRASIL, 2002).

Tal cenário deu origem ao surgimento de inúmeras iniciativas de veiculação de informação de caráter ambiental acerca da produção e do uso dos mais variados produtos e serviços. Grande parte dessas iniciativas pode ser classificada como rotulagem ambiental.

A rotulagem ambiental é um fenômeno relativamente novo no cenário econômicoambiental global. Não existe uma definição consensual que descreve seus componentes básicos nem uma disciplina única que a explique integralmente. É interdisciplinar e existem diversas definições que incluem desde termos como "barreira não tarifária" até "esperança para um futuro comum".

A rotulagem ambiental pode ser entendida como um rótulo que identifica a preferência ambiental global de um produto ou serviço dentro de uma categoria específica 
de produtos e/ou serviços com base em considerações sobre o ciclo de vida. É a prática de informar os consumidores sobre um produto que se caracteriza por um melhor desempenho ambiental em comparação com produtos similares (GROTE, 2002).

Para Douglas \& Isherwood (1979), rótulos ecológicos são marcadores sociais, que definem a escolha de produtos e influenciam a decisão de compra dos consumidores. Para Barham (1997), a rotulagem ambiental é constituída por mensagens explícitas que consideram tanto os valores socialmente definidos sobre o conteúdo real de um produto quanto o modo como esse produto se insere no ambiente global e em suas configurações sociais.

Para a EPA (1998), todos os programas de rotulagem ambiental visam melhorar algum aspecto da qualidade ambiental em seus respectivos países, reduzindo a poluição e contribuindo para a resolução de importantes questões ambientais. Para William (2004), um rótulo ecológico é uma etiqueta adicional sobre produtos ou serviços que indica a natureza da relação do produto ou do processo de produção com o meio ambiente, incluindo as pessoas.

Para Klein (2001), a rotulagem ambiental tem potencial significativo como ferramenta de mercado para informar o consumidor e para alcançar objetivos sociais comuns. A rotulagem é parte de um mecanismo de mercado mais amplo, que pode promover a diversidade, meios de vida tradicionais e o uso sustentável dos recursos. Por isso, torna-se essencial o conhecimento efetivo do funcionamento da rotulagem ambiental para aumentar a eficiência do seu uso (GUERRA, 2003).

O mecanismo de rotulagem ambiental baseia-se em informações disponibilizadas nos rótulos de embalagens para que os consumidores possam optar por adquirir produtos de menor impacto ambiental em relação aos produtos concorrentes disponíveis no mercado. Outras expressões também são utilizadas para designar informações sobre características ambientais impressas no rótulo de produtos, tais como selo verde ou ecológico, declaração ambiental, rótulo ecológico, ecorrótulo, ecosselo e etiqueta ecológica (IPEA, 2011).

Basicamente, um rótulo ambiental identifica a preferência ambiental global de um produto, bem ou serviço, dentro de uma categoria de produto com base em considerações sobre o ciclo de vida. Geralmente, é um símbolo ambiental desenvolvido por um fabricante ou fornecedor de um serviço que é obtido de uma terceira parte que tem caráter imparcial com relação aos produtos que atendem aos padrões estabelecidos por critérios ambientais (GEN, 1999).

Embora seja recente, a rotulagem ambiental é uma realidade em rápida evolução nos mercados e vem senso implementada tanto nas economias desenvolvidas quanto nas economias emergentes e nos demais países em desenvolvimento. 
A rotulagem ambiental procura, com base na informação acerca dos aspectos ambientais de produtos e serviços, que seja acurada e verificável, encorajar a demanda por aqueles produtos que causem menores efeitos ao ambiente, estimulando assim o potencial para uma melhoria contínua ambiental dirigida pelas forças de mercado. Consiste, basicamente, na atribuição de um selo ou rótulo a um produto ou serviço para informar sobre seus aspectos ambientais econômicos e sociais.

Frequentemente, rotulagem e certificação também são usadas como sinônimos; contudo, a rotulagem ambiental (ecolabelling) geralmente relaciona-se às características do produto e destina-se aos consumidores finais, enquanto a certificação ambiental (ecocertification) está mais relacionada aos métodos e processos de produção, sendo direcionada, principalmente, para as indústrias utilizadoras de recursos, objetivando atestar um ou mais atributos do processo de produção (IPEA, 2011).

A rotulagem ambiental é um instrumento econômico e um instrumento de comunicação, visto que busca difundir informações que alterem positivamente padrões de produção e de consumo, aumentando a consciência dos consumidores e produtores para a necessidade de usar os recursos naturais de forma mais responsável.

Do ponto de vista econômico, é um instrumento orientado pela demanda que apela para a responsabilidade ambiental dos consumidores em suas escolhas e busca criar um nicho de mercado para produtos funcionalmente idênticos aos tradicionais, mas que possuem um atributo adicional, requerido por um segmento particular do mercado - serem verdes ou ambientalmente amigáveis.

O mecanismo da rotulagem ambiental é baseado em dois pressupostos:

i) Assume-se que um determinado bem pode ser produzido de formas variadas e que estas formas diferem em termos do impacto ambiental e;

ii) Supõe-se que métodos de produção mais limpos são geralmente mais caros ou requerem a redução em atributos apreciados pelos consumidores.

Neste sentido, ao implementar um programa de rotulagem ambiental a empresa considera que um segmento do mercado de consumo apoiará os custos mais altos de produção requeridos para atingir os padrões ambientais.

Espera-se que, no curto prazo, a rotulagem ambiental contribua para a redução das vendas de produtos poluentes em favor daqueles considerados menos prejudiciais ao ambiente. No longo prazo, espera-se que a rotulagem estimule os produtores em direção a inovações tecnológicas consideradas mais limpas (BLEDA; VALENTE, 2009).

A rotulagem como instrumento, se baseia em três atores principais:

i) Os órgãos públicos de meio ambiente, que estabelecem padrões e normas ambientais a serem alcançados para a proteção do meio ambiente; 
ii) As indústrias e produtores, que são estimulados a melhorar seus sistemas de gestão ambiental e introduzir inovações tecnológicas favoráveis ao meio ambiente;

iii) Os consumidores, que, com escolhas mais conscientes e responsáveis, podem induzir mudanças ambientalmente favoráveis por meio do seu poder de compra.

Geralmente, os programas de rotulagem são voluntários. As exceções, referentes aos rótulos obrigatórios, são para produtos perigosos, de declaração de conteúdo e sobre uso e descarte.

O rótulo ambiental é elaborado para ser uma ferramenta de mercado preventiva e pró-ativa. É um método pelo qual se pretende alcançar a preservação ambiental por meio da orientação sustentável do consumo. É uma iniciativa orientada para o consumidor que exige a conscientização e a participação do consumidor e que também envolve a participação efetiva dos produtores.

Neste sentido, a rotulagem difere das taxas ambientais que afetam diretamente 0 produtor e indiretamente, o consumidor, por meio da variação de preços. O consumidor tem um papel mais ativo e seu desejável suporte para os produtos com rótulo ambiental reforça o programa.

No contexto do mercado varejista, o consumidor não tem contato com questões como: o aquecimento global, o desmatamento das florestas tropicais ou a extinção de espécies, pois essas questões não integram as decisões de consumo e hábitos diários das pessoas. Nesse sentido, o rótulo ambiental que está estampado em um determinado produto indica a natureza do problema ambiental ou social que está relacionado com esse produto e tenta informar o consumidor que esta questão não está sendo agravada pelo consumo desta marca em particular. A seleção deliberada de produtos rotulados oriunda de decisões de compras diárias transforma o consumidor em um ativista ambiental, conscientemente ou não.

A rotulagem ambiental funciona como uma profecia auto-realizável para 0 consumidor relacionada com a gestão ambiental e com o objetivo de continuar a reduzir os problemas ambientais para uma escala passível de gestão. Trata-se de uma iniciativa política complementar que pode ser integrada com objetivos sociais mais amplos, tais como a modernização ecológica.

O aumento do uso de rótulos ambientais, teoricamente, contribui para uma maior conscientização dos consumidores sobre determinada questão ambiental e dessa forma favorece a militância dos consumidores em defesa dessa questão e umentam, dessa forma, a demanda pelos produtos que ostentam determinado rótulo ambiental. Por meio desse ciclo 
de conscientização e demanda, as questões ambientais e sociais vitais podem ser abordadas na arena pública do consumo.

A rotulagem ambiental surgiu há 36 anos e ironicamente ainda se encontra em sua fase inicial, em muitos países. A maioria dos programas de rotulagem ambiental são relativamente recente e ainda está em evolução. A estrutura e os procedimentos desses programas estão evoluindo pelo processo de tentativas e erros.

Durante esse tempo o número de programas de rotulagem ambiental aumentou, mas a aceitação social e a compreensão econômica não foram significativas. Existem poucos estudos referentes à análise da esfera social da rotulagem ambiental e a sua relação com as forças sociais existentes, como: a cultura do consumo, a convicção irrestrita da economia neoliberal, o ambientalismo, a sustentabilidade e o conceito de aldeia global ${ }^{2}$.

Por meio da rotulagem ambiental, os consumidores são educados e incentivados a comprar produtos mais verdes e poder demonstrar seu compromisso com o meio ambiente por meio da decisão de compras baseadas nas informações contidas nos rótulos ambientais sobre produtos que muitas vezes, são mais caros que seus similares.

A participação dos produtores no processo caracteriza-se pela mudança dos processos produtivos para processos considerados mais sustentáveis e pela consideração de fatores ecológicos no cálculo do modelo de negócio. Os produtores, teoricamente, serão recompensados por aumento nas vendas de produtos rotulados e pelo aumento no valor de suas ações empresariais, além de ter melhora sifgnificativa na imagem de suas empresas, já que operam em uma economia global que persegue o crescimento econômico e a evolução do comércio internacional.

O meio ambiente não tem sido a preocupação principal das relações comerciais modernas. No meio dessas realidades sócio-econômicas assimétricas, a rotulagem ambiental trabalha tanto com a dimensão social quanto com a dimensão econômica e tenta satisfazer os objetivos divergentes de cada uma e incentivar relações ambientais harmoniosas.

De acordo com o autor, a rotulagem ambiental está situada entre dois movimentos sociais e, portanto, pode criar uma mudança na sociedade em múltiplos níveis. Em um nível mais amplo, as instituições internacionais estão criando um quadro jurídico que enfatizará a proteção ambiental como resultado de uma reação, devido ao aumento da conscientização de que existe a necessidade prática e moral de mudança dos padrões de produção e de consumo vigentes.

\footnotetext{
2 Termo criado pelo filósofo canadense Herbert Marshall McLuhan, com o intuito de indicar que as novas tecnologias eletrônicas tendem a encurtar distâncias e o progresso tecnológico tende a reduzir todo o planeta à mesma situação que ocorre em uma aldeia: um mundo em que todos estariam, de certa forma, interligados.
} 
No nível político, a sustentabilidade tornou-se um objetivo definitivo para as ONGs e para a sociedade civil que almejam um meio ambiente mais limpo, exigem uma indústria mais responsável e um quadro jurídico efetivo para apoiar este objetivo.

Os produtores respondem a essas pressões por meio de engajamento voluntário em movimentos de responsabilidade social e ambiental. Por fim, existe a reação do consumidor por meio da escolha de produtos com rótulo ambiental. Percebe-se que a rotulagem ambiental tem profundas conseqüências sociais, econômicas e institucionais que são cada vez mais reconhecidas pelos estratos político e social da sociedade.

Desde as origens, a rotulagem ambiental associou-se com governos, empresas e o público em geral na crescente preocupação global com a proteção ambiental. Inicialmente, e principalmente em países desenvolvidos, as empresas comerciais reconheceram que as preocupações ambientais poderiam ser traduzidas em vantagens de mercado para determinados produtos e uma série de declarações e reivindicações ambientais surgiram em associação com determinados produtos.

Apesar de a rotulagem ambiental de produtos ser nova, o tipo de informação disponibilizada para os consumidores está se ampliando e se intensificando. Por meio de uma combinação de prestação obrigatória e voluntária de informações sobre o produto, os consumidores estão recebendo informações não só relacionadas com o país de origem de determinado produto ou com os riscos relacionados com seu uso, mas também sobre a importância desse produto em relação ao meio ambiente.

A rotulagem ambiental está experimentando crescimento significativo de temas como as questões sociais, o comércio justo, os direitos humanos e as mudanças climáticas que estão sendo incorporados aos rótulos dos produtos. Esta progressão da informação é evolutiva e facilita o caminho para que o consumidor e o próprio produtor se conscientizem da necessidade de pensarmos o meio ambiente no qual vivemos.

Os rótulos incluíam afirmações como "reciclável", "eco-friendly", "baixo consumo energético", e "conteúdo reciclado", dentre outras. A rotulagem ambiental dos produtos atraiu, então, os consumidores que estavam à procura de uma forma de reduzir os impactos ambientais adversos, por meio de suas opções de compra.

No entanto, esses rótulos também ameaçaram confundir ainda mais os consumidores. Sem a elaboração de normas orientadoras e investigação feita por uma terceira parte independente, os consumidores não podiam ter certeza de que as afirmações feitas pelas empresas realmente garantiam a marca ambientalmente sustentável que cada produto ostentava.

Essa preocupação com a credibilidade e a imparcialidade levou à formação de organizações públicas e privadas que fornecem rotulagem ambiental de terceira parte. Em 
muitos casos, tal rotulagem tomou e continua a tomar a forma de rótulos ambientais concedidos por programas operados em níveis nacional e regional (ou seja, multinacionais).

Quanto ao responsável pela informação, basicamente existem os rótulos de responsabilidade do fornecedor que são chamados de primeira parte, e os opostos sob a autoridade de uma entidade independente, denominados de terceira parte. Ressalta-se que na terminologia internacional, primeira parte é quem fornece um produto ou serviço ou quem representa os seus interesses. Segunda parte é quem compra ou quem representam os seus interesses e terceira parte é uma parte independente das outras envolvidas na relação.

Em virtude da proliferação de rótulos e selos ambientais no mercado e da necessidade de se estabelecer padrões e regras para o seu uso adequado, a Organização Internacional de Normalização (ISO), desenvolveu normas para a rotulagem ambiental e classificou os diversos tipos de rotulagem (BRASIL, 2002).

O Quadro a seguir, apresenta a classificação feita pela ISO com suas respectivas descrições.

Quadro 3.1 Classificação dos tipos de rotulagem ambiental (ISO)

\begin{tabular}{|c|l|}
\hline Tipo & \multicolumn{1}{|c|}{ Descrição } \\
\hline Tipo I & $\begin{array}{l}\text { Programas de terceira parte, fundamentos em } \\
\text { múltiplos critérios, voluntários, que atribuem uma } \\
\text { licença para o uso de rótulos ambientais em } \\
\text { produtos, indicando a preferência ambiental } \\
\text { global do mesmo, dentre uma categoria de } \\
\text { produtos, baseados em consideraçãoes de ciclo } \\
\text { de vida. (Selos Verdes) }\end{array}$ \\
\hline Tipo II & \begin{tabular}{l} 
Autodeclarações ambientais informativas \\
\hline Tipo III
\end{tabular} \\
\hline Tipo IV & $\begin{array}{l}\text { Programas voluntários que fornecem dados } \\
\text { ambientais quantificados de um produto, sobre } \\
\text { categorias preestabelecidas de parâmetros } \\
\text { definidos por uma terceira parte qualificada, } \\
\text { baseados numa avaliação de ciclo de vida e } \\
\text { verificados por essa ou outra terceira parte } \\
\text { habilitada. }\end{array}$ \\
\hline & $\begin{array}{l}\text { Rótulos ambientais monocriteriosos, atribuídos } \\
\text { por uma terceira parte, que se referem apenas a } \\
\text { um aspecto ambiental, sem serem baseados em } \\
\text { considerações de ciclo de vida. }\end{array}$ \\
\hline
\end{tabular}

Fonte: MMA (2002) 
A despeito das definições substancialmente detalhadas e complexas, pode-se simplificar a relação dos tipos destacando que o Tipo I refere-se aos clássicos selos verdes o Tipo II diz respeito às declarações efetuadas pelos próprios fornecedores, normalmente os próprios fabricantes, e o Tipo III ainda está em desenvolvimento, mas consiste, essencialmente, no estabeleceimento de categorias de parâmetros, a partir de uma avaliação do ciclo de vida e na divulgação dos dados quantitativos relativos a esses parâmetros para cada produto e que são verificados por uma terceira parte.

\section{Quadro 3.2 Comparação dos três tipos de rótulos e declarações}

\begin{tabular}{|c|c|c|c|c|}
\hline Tipo & Critérios & Ciclo de vida & Seletividade & Terceira parte \\
\hline I & Múltiplos & Sim & Sim & Sim \\
\hline II & Simples & Não & Não & Não \\
\hline III & Múltiplos & Sim & Não & Sim \\
\hline
\end{tabular}

Fonte: Elaboração própria, 2015.

É importante observar que, do ponto de vista da iniciativa, os selos podem ser: 1 ) conduzidos por governos - o Programa Nacional de Conservação de Energia Elétrica (Procel) no Brasil; ii) funcionar de forma independente, mas podendo aceitar assistência técnica governamental - Ecolabel da União Europeia; ou iii) serem estabelecidos pelo próprio setor industrial ou produtivo, por meio de autodeclarações ambientais.

Existem outros tipos de rótulos ambientais, bastante específicos, como, por exemplo, a certificação de agricultura orgânica, na qual se atesta que determinados produtos agrícolas são provenientes de produções sem o uso de substâncias químicas, sejam alimentos ou para outros usos, como têxteis.

Em todo o mundo, existem muitos outros sistemas de rotulagem ambiental de terceira parte em uso ou sendo desenvolvido que são "híbridos" de rotulagem ambiental, porque têm focos mais estreitos do que um programa normal de rotulagem ambiental.

Para Barboza (2011), além das tipologias apresentada pela ISO, os selos também podem ser classificados em positivos, negativos ou neutros.

- Os programas positivos, geralmente voluntários, são aqueles que atestam que o produto alcançou um ou mais atributos ambientalmente preferíveis. Por exemplo, os selos de aprovação atestando que o produto atende aos critérios de determinado programa (Ecolabel, Blue Angel etc.) ou os selos referentes a um único atributo, tais como biodegradáveis orgânicos ou oriundos de material reciclado.

- Os selos negativos ou de advertência são de uso obrigatório por questões de saúde e segurança e servem de alerta para os ingredientes prejudiciais ou perigosos contidos no produto. Por exemplo, os referentes a pesticidas e agrotóxicos e aqueles colocados 
obrigatoriamente nas carteiras de cigarro no Brasil por determinação do Ministério da Saúde (MS).

Por fim, os selos neutros informam, resumidamente, características ambientais sobre um produto para orientar o consumidor. Por exemplo, o selo Procel de conservação de energia, que permite ao consumidor escolher um produto de menor consumo energético comparando-o aos demais da mesma categoria.

Estes programas alternativos se concentram em um único setor (por exemplo, a indústria florestal, a indústria química, etc.), e/ou abarcam apenas um problema ambiental (por exemplo, a qualidade do ar, conservação de energia, etc.), e/ou consideram apenas uma única fase do ciclo de vida do produto em suas aplicações (por exemplo, o uso do produto, o descarte do produto/a reciclagem do produto, etc.).

Deve-se salientar, ainda, que alguns outros programas de rotulagem ambiental do tipo I foram concebidos e implementados para lidar e reconhecer mais do que simplesmente aspectos de desempenhos ambientais.

Em um típico programa de rotulagem ambiental, as categorias de produtos e os critérios de rotulagem ambiental são determinados por uma organização independente com a ajuda de um grupo de assessoria técnica complementar.

Geralmente, uma vez que uma categoria é escolhida, alguma forma de avaliação do ciclo de vida é conduzida. Esta avaliação pode incluir extração de matéria-prima, fabricação, distribuição, utilização e eliminação. Os parâmetros de diferenciação, por exemplo, utilização de energia e toxicidade são utilizados como base para o desenvolvimento de critérios.

As empresas que querem participar de um programa de rotulagem ambiental preenchem um contrato e apresentam os seus produtos para testes de conformidade e de verificação que são feitos por organização de terceira parte. Se os produtos forem aprovados, as empresas pagam taxas de licenciamento para o uso do logo do programa de rotulagem ambiental por um determinado período. O uso do rótulo ambiental se restringe ao produto aprovado e é normalmente monitorado pela agência de gestão.

\subsection{Evolução da rotulagem ambiental}

O primeiro rótulo ou selo ambiental foi lançado em 1977, na Alemanha, o "Anjo Azul" (Blau Engel), atestando produtos oriundos da reciclagem e com baixa toxidade. $O$ Programa de rotulagem ambiental da Alemanha, foi criado pelo Ministério do Interior, que na época respondia pelas questões de proteção ambiental, e pelos Ministros dos Estados Federais, foi o pioneiro na implementação de selos verdes e serviu de modelo para as 
iniciativas de outros países. Desde 1986 a responsabilidade pelo programa é do Ministério de Meio Ambiente, Conservação da Natureza e Segurança Nuclear (CORREA, 1998).

O Canadá foi o segundo país a desenvolver um programa de rotulagem ambiental, denominado Environmental Choice Program, já no fim da década de 1980. Inicialmente organizado e conduzido pelo governo canadense, no âmbito do Standards Council of Canadá, foi posteriormente privatizado, sendo atualmente gerido pela Terra choice Environmental Systems Inc.

A partir de 1988, os países nórdicos - Noruega, Suécia, Finlândia, Dinamarca e Islândia - criaram o selo Nordic Swan. Os Estados Unidos desenvolveram o Green Seal, em 1989 e o Japão instituiu no mesmo ano o Eco-Mark. Em 1992, a União Europeia lançou o rótulo ambiental comunitário, Ecolabel Flower, cujo símbolo é uma Flor. Por sua vez, o Brasil possui, desde 1993, o selo de Qualidade Ambiental da Associação Brasileira de Normas Técnicas (ABNT), o Colibri.

Cabe ressaltar que o fato de a União Européia ter desenvolvido um rótulo ambiental comunitário não impede que os programas de rotulagem ambiental nacionais funcionem. $\mathrm{Na}$ Alemanha, por exemplo, o rótulo ambiental comunitário não substituiu o Blau Engel; os dois rótulos coexistem no mercado alemão e a concorrência entre os dois é proveitosa e favorece a fabricação de produtos menos prejudiciais ao meio ambiente.

Originalmente, alguns desses programas estabeleciam critérios baseados em alguns poucos aspectos ambientais dos produtos que eram julgados em decorrência de serem os mais críticos para o ambiente. Entretanto, começou-se a introduzir o conceito de ciclo de vida, com alguns programas pretendendo desenvolver análises completas, como foi o caso do Programa francês e o Programa da União Européia. De qualquer modo, a maioria dos programas tiveram como fundamento as experiências da Alemanha ou do Canadá.

É importante ressaltar que o rótulo ambiental europeu provocou controvérsias em virtude da possibilidade de se converter em barreira técnica para o acesso ao mercado europeu. Ao se efetuar as análises de ciclo de vida, com base nos primeiros critérios estabelecidos para a concessão do rótulo, poderiam-se privilegiar processos de produção e aspectos ambientais com potencial para excluir produtos oriundos de fora do continente Europeu.

Entretanto, a International Standardization Organization (ISO), em 1993, constituiu o Comitê Técnico 207(ISO/TC-27), com o mandato para desenvolver normas e instrumentos de gestão ambiental que receberam a designação de série ISO 14000. Na série ISO 14000 encontram-se as normas ISO 14020, publicadas em 1998, que estabeleceram os princípios para a rotulagem e as declarações ambientais, e as normas ISO 14024, de 1999, que definem as regras para os programas de rótulos do Tipo I. 
Estas normas representam o consenso internacional dos princípios e aspectos que devem ser seguidos pelos programas de rotulagem ambiental e constituem um marco internacional para essa atividade. Em 1994, foi constituído o Global Ecolabeling Network (GEN), com a finalidade de estimular os países a prestarem assistência mútua, cooperação e intercâmbio de informações, e aprimorar e desenvolver programas de rotulagem ambiental em todo o mundo. Atualmente, o GEN conta com 24 membros e é referência para rotulagem ambiental global.

\section{Quadro 3.3 - Programas de rotulagem ambiental tipo I no mundo}

\begin{tabular}{|c|c|}
\hline Países com Programas de Rotulagem & Ano de Implementação \\
\hline Alemanha & 1978 \\
\hline Áustria & 1991 \\
\hline Austrália & 2001 \\
\hline Brasil & 1993 \\
\hline Canadá & 1988 \\
\hline Coréia do Sul & 1992 \\
\hline Croácia & 1993 \\
\hline Espanha & 1994 \\
\hline França & 1992 \\
\hline Hungria & 1994 \\
\hline Holanda & 1992 \\
\hline Hong Kong & 2000 \\
\hline Índia & 1991 \\
\hline Indonésia & 1995 \\
\hline Israel & 1993 \\
\hline Japão & 1989 \\
\hline Nova Zelândia & 1990 \\
\hline República Checa & 1994 \\
\hline Taiwan & 1992 \\
\hline Tailândia & 1993 \\
\hline Suécia & 1992 \\
\hline Estados Unidos & 1989 \\
\hline Países Nórdicos & 1989 \\
\hline União Européia & 1992 \\
\hline África & Em elaboração \\
\hline
\end{tabular}

Fonte: Baseado em Juliani (2010)

O GEN visa construir a confiança entre os países-membros para possibilitar o reconhecimento mútuo da certificação de programas desenvolvidos em países diferentes. 
No reconhecimento mútuo busca-se a identificação, a equivalência, a harmonização e o acordo entre critérios principais comuns, o que torna o processo de certificação mais simples e barato entre os países, evitando barreiras na exportação. Ressalta-se que não existe um selo verde mundial reconhecido em todos os países (LADVOCAT, 2010).

Percebe-se que a implantação de programas de rotulagem, embora em rápida evolução, é uma experiência relativamente recente. São escassos os estudos que avaliem os efeitos ambientais dos programas de rotulagem no Brasil e no mundo, já que ainda são raras as estimativas disponíveis sobre a eficácia dos programas - associando-os a melhorias de qualidade ambiental.

É difícil isolar e medir os benefícios dos rótulos, comparativamente aos efeitos provocados por demais medidas ambientais - a eficácia pode ser avaliada apenas indiretamente, pela mudança no comportamento do consumidor, ao demandar produtos ambientalmente corretos (BRAGA; MIRANDA, 2002).

\subsection{Objetivos da Rotulagem Ambiental}

A essência da rotulagem ambiental é gerar apoio político para a melhoria da gestão ambiental e para elevar os padrões ambientais por meio da escolha consciente do consumidor. Efetivamente, a rotulagem ambiental pode institucionalizar a gestão ambiental de bens e de serviços na produção e no consumo (DEERE, 1999).

A rotulagem ambiental não inclui o custo da poluição em sua base econômica, tal como um imposto ambiental e de forma mais eficaz, minimiza os poluentes criados. O rótulo ambiental incorpora um amplo espectro de problemas ambientais e sociais e tornou-se uma ferramenta útil para os governos incentivarem as boas práticas ambientais e para as empresas identificarem e estabelecerem mercados no âmbito nacional ou no internacional, para os seus produtos ambientalmente sustentáveis. Muitos países têm algum tipo de rotulagem ambiental em uso, enquanto outros estão considerando o desenvolvimento de programas de rotulagem ambiental.

O Compromisso com objetivos claros tem sido fundamental para o sucesso dos programas de rotulagem ambiental em todo o mundo. Enquanto os programas oficialmente podem expressá-los de forma diferente, três objetivos principais são geralmente estabelecidos e seguidos:

\subsubsection{Proteger o meio ambiente}

A Conservação e a proteção do meio ambiente, geralmente são objetivos primordiais. Por meio de programas de rotulagem ambiental, os governos e / ou as 
autoridades de programas não governamentais visam influenciar as decisões de consumo e incentivar a produção e o consumo de produtos ambientalmente sustentáveis além da prestação e da utilização de serviços ambientalmente sustentáveis.

Dessa forma, a rotulagem ambiental serve como um instrumento de mercado destinado a garantir uma melhoria ambiental. Os Objetivos ambientais específicos podem incluir:

- incentivar uma gestão eficiente dos recursos renováveis para garantir a sua disponibilidade para as gerações futuras;

- promover o uso eficiente dos recursos não renováveis, incluindo combustíveis fósseis;

- facilitar a redução, a reutilização e a reciclagem de resíduos comerciais e do consumidor de resíduos;

- incentivar a protecção dos ecossistemas e da diversidade de espécies e;

- incentivar a boa gestão dos produtos químicos.

\subsubsection{Incentivar a inovação e a liderança ambientalmente saudável}

Programas de rotulagem ambiental oferecem um incentivo de mercado para as empresas ambientalmente inovadoras e progressistas, por meio da obtenção e da promoção de um rótulo ambiental. Ao oferecer produtos que reduzem a pressão sobre o meio ambiente, as empresas líderes podem estabelecer ou reforçar um nicho de mercado e imagem corporativa positiva entre os consumidores, o que Ihes confere vantagem em relação às outras empresas que possivelmente irão seguí-las.

Geralmente, os critérios de rotulagem ambiental são definidos para premiar somente os melhores desempenhos ambientais em uma categoria de produto. A maioria dos programas de forma gradual e progressivamente aumentam os padrões para incentivar os produtores e os prestadores de serviços para manter o ritmo com novas e emergentes oportunidades de melhoria de desempenho e mudanças no mercado.

\subsubsection{Conscientizar o consumidor sobre questões ambientais}

Os programas de rotulagem ambiental também podem servir para aumentar a conscientização dos consumidores com relação a questões ambientais e às implicações de suas escolhas. Em países onde existe um alto grau de conscientização dos consumidores, um rótulo ambiental confiável que fornece informações confiáveis sobre os impactos 
ambientais dos produtos no mercado podem ser extremamente úteis para promover a seleção de produtos rotulados.

Já em países onde os consumidores não são efetivamente motivados por preocupações ambientais, a rotulagem ambiental pode ser usada para promover ações benéficas para o meio ambiente.

Cabe ressaltar que alguns gestores de programas de rotulagem ambiental e autoridades governamentais tem identificado não exatamente um quarto objetivo, mas outra função muito importante para a rotulagem ambiental. Referem-se ao mérito da rotulagem ambiental ser usada como uma ferramenta de mercado positiva, isto é para promover produtos para exportação em mercados globais onde a consicencia do consumiodor e as preocupações com os impactos ambientais já estão estabelecidos e são significantes.

\subsubsection{Fortalecer a educação ambiental}

Pela sua própria natureza, os rótulos ambientais constituem um importante instrumento de educação dos consumidores em direção à mudança de comportamento e na formação de hábitos de consumo mais positivos, ou seja, ambientalmente mais corretos.

Com efeito, o acesso do consumidor à informação, voluntária e com base científica, sobre produtos preferíveis do ponto de vista ambiental, é um fator de estímulo a uma tomada de decisão de compra mais responsável em relação ao meio ambiente.

Este efeito será mais efetivo, quanto maior for a predisposição dos consumidores em dar atenção aos aspectos ambientais. Contudo, deve-se ressaltar que em diversos países em desenvolviemnto, como é o caso da Índia, um dos propósitos principais da introdução dos rótulos ambientais foi justamente a intenção de desenvolver uma consciência ambiental nos consumidores os quais, por condicionantes socioculturais e econômicos, não teriam, em princípio, dentro deas suas prioridades, essa consciência suficientemente enraizada. Pretende-se, de fato, dar visibilidade aos produtos com melhor desempenho ambiental e proporcionar ao consumido a oportunidade de contribuir, com suas próprias decisões no quotidiano, par uma mudança positiva do ponto de vista ambiental.

Em suma os rótulos ambientais possibilitam a incorporação dos aspectos relativos ao meio ambiente no dia a dia dos cidaãos e evidenciam a sua capacidade de interferência.

\subsubsection{Desenvolver mercados}

Do ponto de vista das empresas, a rotulagem ambiental é um instrumento que, ao disseminar no mercado a inovação e a adoção de melhores tecnologias e processos, de forma transparente e independente, estimula e premia as empresas líderes. $O$ auxílio 
institucional tem como consequência o incentivo mercadológico para o desenvolvimento de mercados para os produtos que contemplam na sua concepção os aspectos ambientais.

Naturalmente, esse efeito mercadológico é o motor que alimenta a adesão das empresas à rotulagem ambiental. Igualmente, um programa de sucesso tende, de fato, criar uma dinâmica para a melhoria contínua ambiental dos produtos e desenvolver mercados para produtos que, de outra maneira, talvez não fossem percebidos pelos consumidores, em virtude da eventual sofisticação técnica dos elementos que os diferenciam dos demais e que podem estar além da compreensão do usuário comum.

\subsubsection{Fortalecer políticas públicas ambientais}

A rotulagem ambiental é uma das ferramentas disponíveis para a implementação de políticas públicas orientadas para o desenvolvimento de novos padrões de consumo, ambientalmente mais saudáveis, e para o fomento da evolução da produção industrial.

Deve-se destacar que os programas de rotulagem ambiental são, por definição, voluntários e, na sua maioria, conduzidos por organizações não governamentais. A generalidade dos programas no mundo conta com a participação ativa dos governos como seus promotores ou incentivadores.

Com o crescente desenvolviemnto de rótulos ambientais no mundo, os seus efeitos nos mercados passaram a desempenhar uma importância cada vez maior. Em particular, a possibilidade de se converterem em potenciais obstáculos ao comércio internacional temIhes transformado em fator de aumento da competitividade nas empresas e em instrumento de inserção no mercado internacional ou, pelo menos, de ultrapassar tais potenciais barreiras.

De fato, proporcionar um instrumento para demonstrar qualidade ambiental para os mercados de exportação tem sido um dos objetivos enunciados pelos rótulos ambientais em implantação em diversos países em desenvolvimento.

Assim, ao se formular políticas públicas em relação ao meio ambiente, o uso de rótulos ambientais tem sido considerado como uma ferramenta positiva para promover uma mudança nos padrões de produção e de consumo.

\subsection{Fundamentos técnicos da rotulagem ambiental}

Diante da proliferação de rótulos ambientais sem padrões comuns regulatórios, buscou-se organizar um sistema confiável de orientações para a normatização ambiental a nível internacional, o que vem sendo realizado pela International Standardization Organization (ISO), desde 1993, quando foi constituído o Comitê Técnico 207 (ISSO/TC- 
207), com o mandato para desenvolver normas e instrumentos de gestão ambiental e que receberam a designação de série ISO 14000.

$\mathrm{Na}$ série ISO 14000 , os certificados atestam a responsabilidade ambiental no desenvolvimento de atividades e de produtos de uma organização. Para a obtenção e manutenção de certificados da série ISO 14000, a organização tem de se submeter a auditorias periódicas, realizadas por uma empresa certificadora, credenciada e reconhecida pelos organismos nacionais e internacionais (IPEA, 2011).

As normas da série ISO 14000 podem ser reunidas, genericamente, em dois grandes grupos:

i) normas orientadas para processos e organizações - sistema de gestão ambiental, avaliação de desempenho ambiental e auditoria ambiental (quadro 3.4); e

ii) normas orientadas para produtos - Avaliação do Ciclo de Vida (ACV), rotulagem ambiental e aspectos ambientais dos produtos (quadros 3.5 e 3.6).

\section{Quadro 3.4 - Normas ISO de gestão e auditoria ambientais}

\begin{tabular}{|l|l|l|}
\hline Abrangência da norma & Número da Norma & \multicolumn{1}{|c|}{ Descrição da norma } \\
\hline Gestão Ambiental & ISO14001 & Guia de uso para o sistema de gestão ambiental \\
\hline Gestão Ambiental & ISO14004 & $\begin{array}{l}\text { Guia para os princípios e técnicas de suporte } \\
\text { para o sistema de gestão ambiental }\end{array}$ \\
\hline Auditoria Ambiental & ISO14010 & Princípios gerais de auditoria ambiental \\
\hline Auditoria Ambiental & ISO14011 & $\begin{array}{l}\text { Procedimentos de auditoria para o sistema de } \\
\text { gestão ambiental }\end{array}$ \\
\hline Auditoria Ambiental & ISO14012 & $\begin{array}{l}\text { Critérios de qualificação para auditores } \\
\text { ambientais }\end{array}$ \\
\hline Auditoria Ambiental & ISO14015 & Diretrizes para auditoria ambiental \\
\hline
\end{tabular}

Fonte: IPEA (2011)

A segunda série de normas está relacionada com a rotulagem ambiental e com as diretrizes para a avaliação de desempenho ambiental. São indicados os princípios para todos os rótulos, métodos e testes de verificação e procedimentos que devem ser usados. Nesta categoria estão indicados os modelos quantitativos que podem ser usados para a verificação de qualidade e de adequação do rótulo às reais percepções dos consumidores (Quadro 3.5).

Já a terceira série de normas contempla os princípios e inventários do ciclo de vida de produtos, o vocabulário usado em gestão ambiental e um guia de inclusão de aspectos ambientais em normas para produtos (Quadro 3.6). 
QUADRO 3.5 - Normas ISO de rotulagem e avaliação de desempenho ambiental

\begin{tabular}{|l|l|l|}
\hline Abrangência da Norma & Número da Norma & Descrição da Norma \\
\hline Rotulagem Ambiental & ISO14020 & Princípios básicos para todos os rótulos \\
\hline Rotulagem Ambiental & ISO14021 & $\begin{array}{l}\text { Termos e definições da rotulagem ambiental Tipo } \\
\text { Il (autodeclarações) }\end{array}$ \\
\hline Rotulagem Ambiental & ISO14022 & Simbologia da rotulagem \\
\hline Rotulagem Ambiental & ISO14023 & Metodologia de testes e verificação \\
\hline Rotulagem Ambiental & ISO14024 & $\begin{array}{l}\text { Guia de princípios e procedimentos para o rótulo } \\
\text { ambiental Tipo I (selos verdes) }\end{array}$ \\
\hline Rotulagem Ambiental & ISO14025 & $\begin{array}{l}\text { Guia de princípios e procedimentos para o rótulo } \\
\text { ambiental Tipo III, referente à Avaliação do Ciclo } \\
\text { de vida do Produto. }\end{array}$ \\
\hline $\begin{array}{l}\text { Avaliação } \\
\text { desempenho ambiental }\end{array}$ & ISO14031 & Diretrizes para a avaliação ambiental \\
\hline Fonte: IPEA (2011) &
\end{tabular}

Fonte: IPEA (2011)

\section{Quadro 3.6 - Normas ISO de Avaliação do Ciclo de Vida, termos usados em gestão ambiental e aspectos ambientais para produtos.}

\begin{tabular}{|l|l|l|}
\hline Abrangência da Norma & Número da Norma & Descrição da Norma \\
\hline Avaliação do Ciclo de Vida & ISO14040 & Princípios e práticas da ACV \\
\hline Avaliação do Ciclo de Vida & ISO14041 & Análise de inventários \\
\hline Avaliação do Ciclo de Vida & ISO14042 & Avaliação de impactos ambientais \\
\hline Avaliação do Ciclo de Vida & ISO14043 & Interpretação de resultados \\
\hline Termos e definições & ISO14050 & Vocabulário de gestão ambiental \\
\hline $\begin{array}{l}\text { Aspectos ambientais de } \\
\text { normas para produtos }\end{array}$ & Guia ISO64 & $\begin{array}{l}\text { Guia para a inclusão de aspectos ambientais } \\
\text { em normas para produtos }\end{array}$ \\
\hline
\end{tabular}

Fonte: IPEA (2011)

Os rótulos ambientais podem se referir a diferentes etapas do processo produtivo de forma simultânea, ciclo de vida do produto, ou apenas a uma delas, tais como: a origem do produto, a extração da matéria-prima, o uso de tecnologias limpas e o descarte final (IPEA, 2011).

O rótulo pode, ainda, especificar os limites de conteúdo de uma substância considerada nociva ao consumo humano, por exemplo, indicar os limites toleráveis de certos poluentes, ou se referir ao desempenho no consumo final do produto, como no caso do consumo de energia de um determinado equipamento. Atualmente, já se estuda, também, o 
impacto dos produtos nas mudanças climáticas e são feitas análises considerando-se apenas aspectos associados às emissões de gases de efeito estufa, a chamada "pegada de carbono".

\subsubsection{Norma ISO 14024}

A Norma ISO14024 "Environmental Labels and declarations- Type I environmental Lablelling - Guiding principles and procedures", tem o objetivo de assegurar a transparência e a credibilidade na implementação de um programa de rotulagem ambiental do Tipo I e harmonizar os princípios e procedimentos aplicáveis a esses programas.

Para MMA (2002), a norma estabelece os princípios que devem nortear um programa de rotulagem ambiental do Tipo I, que estão listados a seguir:

- Natureza voluntária - Os programas do Tipo I, mesmo os desenvolvidos e operados por agências governamentais, devem ser de natureza voluntária. Isso quer dizer que os produtores deverão ter a liberdade de opção para aderir ou não ao programa, seja na sua concepção, seleção das categorias e estqabelecimento dos critérios, quanto se candidatarem a receber a rotulagem.

- Relação com a ISO14020 - da mesma forma que as autodeclarações, os programas de rotulagem ambiental de terceira parte devem atender aos princípios da ISO14020- "Environmental labels and declarations - Basic principles".

- Cumprir a legislação ambiental e outros regulamentos aplicáveis - as regras de um programa de rotulagem de terceira parte devem assegurar que a concessão e a manutenção do rótulo estejam condicionadas às leis ambientais e a outras regras pertinentes.

- $\quad$ Consideração do ciclo de vida do produto - os critérios devem ser estabelecidos levando em consideração o ciclo de vida do produto, desde a extração das matérias primas que o compõem até sua disposição final, de forma a assegurar que, ao reduzir um impacto, este não estará sendo transferido para outro estágio do ciclo de vida do produto.

- $\quad$ Seletividade - os critérios ambientais devem ser estabelecidos de forma que diferenciam aqueles produtos ambientalmente preferíveis comparados aos outros da mesma categoria, com base em uma diferença mensurável nos impactos ambientais. Dessa forma, os produtores cujos produtos ainda não estejam aptos a serem premiados com o rótulo, podem 
promover objetivamente as mudanças necessárias para que passem a se adequar aos requisitos determinados, resultando assim em uma melhoria ambiental.

- Realismo de critérios - os critérios devem ser estabelecidos em níveis realisticamente alcançáveis e levar em consideração os impactos ambientais relativos e a capacidade e precisão de medições.

- $\quad$ Adequação ao uso e desempenho - o desenvolvimento dos critérios deve ter em vista a adequação ao uso (qualidade) e os níveis de desempenho do produto. Dessa forma, é possível garantir qur o atendimento aos critérios ambientais não afetará a qualidade do produto.

- Critérios revisados periodicamente - os critérios devem ser revisados periodicamente, considerando fatores como novas tecnologias, novos produtos, novas informações ambientais e alterações de mercado, além de terem um período de validade predefinido.

- Consulta às partes interessadas - o processo de seleção, revisão, escolha das categorias de produtos e do estabelecimento dos critérios ambientais deve prever um processo formal de consulta e a participação aberta das partes interessadas.

- Verificabilidade - todos os elementos dos critérios devem ser verificáveis de modo objetivo.

- $\quad$ Transparência - um programa de rotulagem ambiental do Tipo I deve demonstrar transparência em todos os estágios de seu desenvolvimento. A visibilidade implica em que a informação deva estar disponível às partes interessadas para análise e comentários. Esta informação pode ser referente à seleção das categorias de produto, seleção e desenvolvimento dos critérios ambientais, características funcionais do produto, métodos de teste e verificação, procedimentos de certificação e premiação, período de revisão, período de validade, evidências nas quais se baseou a concessão do rótulo (asseguradas as questões de caráter confidencial), fontes de recursos para desenvolvimento do programa, verificação da conformidade.

- Não devem criar ou ter a intenção de criar obstáculos ao comércio internacional - os procedimentos e requisitos de um programa de rotulagem ambiental não devem ser preparados, adotados ou aplicados, com vistas a criar obstáculos desnecessários ao comércio internacioal.

- Acessíveis a todos os potenciais solicitantes (nacionais ou estrangeiros) - a solicitação ou a participação em um programa de rotulagem 
ambiental deve ser aberta a todos os solicitantes em potencial. Todos os pretendentes que atendam aos requisitos para uma determinada classe de produtos devem receber o rótulo.

- Os critérios ambientais definidos com base científica - o desenvolvimento e a seleção dos critérios para rotulagem devem se basear em princípios científicos e de engenharia sólidos. Os critérios devem ser capazes de sustentar que os produtos que se habilitaram ao rótulo são ambientalmente preferíveis àqueles que não foram qualificados.

- Independência e ausência de conflitos de interesse - os programas de rotulagem ambiental devem assegurar que não sofrem influências indevidas. Os programas devem demonstrar, por exemplo, que as fontes de recursos não criam conflitos de interesse.

- Acessibilidade - os custos e taxas devem maximizar o acesso ao rótulo. As taxas dos programas de rotulagem ambiental, cobradas por organismos certificadores, devem incluir as despesas de solicitação, testes e administração. Em princípio, os custos e taxas por concessão e manutenção do rótulo devem se basear nos custos de todo o programa e serem mantidos de forma mais baixa possível para maximizar a acessibilidade ao rótulo. Quaisquer taxas devem ser aplicadas equitativamente a todos os solicitantes e licenciados.

- $\quad$ Confidencialidade - os programas devem garantir que todas as informações relativas ao licenciado e ao produto rotulado são confidenciais.

- Reconhecimento mútuo - é encorajado o reconhecimento mútuo entre os programas de rotulagem ambiental.

A ISO 14024 também faz algumas recomendações relativas aos procedimentos que devem ser adotados por um programa de rotulagem ambiental operado por um organismo independente de terceira parte. Estes procedimentos dizem respeito:

- À seleção das categorias de produtos;

- Ao desenvolvimento, análise e modificação dos critérios ambientais de rotulagem;

- À identificação das características funcionais do produto; e

- Ao estabelecimento dos procedimentos de certificação e outros elementos administrativos do programa.

Com relação à definição dos critérios ambientais, a norma recomenda que seja feita atentando-se para o ciclo de vida do produto. Isso não quer dizer que haja necessidade de 
se efetuar uma nálise do ciclo de vida do produto, que é um processo muito demorado e oneroso, que poderia inviabilizar o programa de rotulagem.

O estudo deve concluir que alguns imapctos ambientais de determinados estágios do ciclo de vida do produto são insignificantes em comparação com outros, não justificando maiores considerações. De qualquer maneira, o estudo deve mostrar que a seleção dos critérios ambientais não causará a transferência dos impactos de um estágio do ciclo de vida para outro, ou de um meio para outro, sem que haja um ganho ambiental líquido.

O processo de definição de requisitos deve considerar as questões ambientais relevantes locais, regionais e globais, a tecnologia disponível e os aspectos econômicos. Os critérios devem ser expressos em termos de impactos ambientais e recursos naturais.

Paralelamente ao estabelecimento dos critérios, o organismo que operará o programa deve considerar os tipos de testes que serão utilizados para avaliação da conformidade dos produtos. Deve se atentar para a viabilidade técnica e econômica de tais testes. 0 organismo deve deixar claro quais os testes exigidos para verificação de cada critério e avaliar a disponibilidadem de laboratórios competentes capazes de executar os mesmos.

A norma estabelece recomendações que devem ser seguidas por um organismo que conduz um programa de rotulagem ambienmtal do Tipo I. Dentrem as recomendações, duas merecem destaque, pois delas dependem todos os procedimentos de rotulagem: o estabelecimento dos regulamentos gerais do programa de rotulagem e as regras específicas para cada família de produto.

As regras gerais controlam a operação global do programa, já as regras específicas de cada categoria de produtos devem conter a descrição dos critérios ambientais, os métodos de avaliação da conformidade, além de outros requisitos técnicos aplicáveis àquela classe de produtos.

\subsubsection{Norma ISO 14020}

Estabelece princípios aplicáveis em todos os rótulos e declarações ambientais. São eles:

Princípio 1 - rótulos e declarações ambientais devem ser precisos, verificáveis, relevantes e não enganosos.

Princípio 2 - procedimentos e exigências para rótulos e declarações ambientais não devem ser preparados, adotados ou aplicados com vistas a criar obstáculos desnecessários ao comércio internacional.

Princípio 3 - rótulos e declarações ambientais devem ser baseados em metodologia científica que seja sificientemente meticulosas, detalhada e completa para apoiar a declaração e que produza resultados que sejam acurados e reproduzíveis. 
Princípio 4 - é recomendável que o desenvolvimento de rótulos e declarações ambientais, sempre que for apropriado, leve em consideração o ciclo de vida do produto ou serviço.

Princípio 5 - rótulos e declarações ambientais não devem inibir a inovação que mantenha ou tenha o potencial de melhorar o desempenho ambiental.

Princípio 6 - quaisquer exigências administrativas ou demanda de informação relacionada a rótulos e declarações ambientais devem ser limitadas àquelas necessárias para estabelecer a conformidade com os critérios aplicáveis aos rótulos e declarações ambientais.

Princípio 7 - O processo de desenvolvimento de rótulos e declarações ambientais deve incluir uma consulta ampla às partes interessadas. Esforços razoáveis devem ser feitos para atingir consenso em todo o processo.

Princípio 8 - Informações dos aspectos ambientais dos produtos e serviços rlevantes ao rótulo e declaração ambiental devem ser disponibilizadas para compradores ou possíveis compradores pela parte que faz o rótulo ou declaração ambiental.

Princípio 9 - Informação relacionada ao procedimento, metodologia e qualquer critério usado para fundamentar rótulos e declarações ambientais devem ser disponibilizados e fornecidos, quando solicitados, a todas as partes interessadas.

Ressalta-se que a Norma Brasileira (NBR) ISO 14020, da Associação Brasileira de Normas Técnicas (ABNT), representa a internalização da Norma ISO 14020, no Brasil e de acordo com ABNT (2009), além disso, é desejável que os programas de rotulagem: sejam conduzidos por uma entidade de terceira parte, de forma imparcial; não sejam discriminatórios, isto é, sejam acessíveis a produtores de qualquer tamanho, capital, tecnologia e nível de investimento.

\subsubsection{Avaliação do ciclo de vida do produto}

A definição de Avaliação do Ciclo de Vida (ACV), segundo a ISSO/TC 207 é: "Compilação e avaliação das entradas, das saídas e dos impactos ambientais potenciais de um sistema de produto ao longo do seu ciclo de vida". A análise de ciclo de vida é uma ferramenta desenvolvida para auxiliar na busca contínua de desempenho ambiental. Ao contrário de outras técnicas comumente utilizadas em avaliações ambientais, a análise de ciclo de vida tem uma abordagem relativa e apresenta algumas características específicas e é considerada um ponto de partida óbvio para programas de rotulagem ambiental (SETAC, 2002).

A expressão ciclo de vida é usada para referir-se a todas as etapas e processos de um sistema de produção de produtos ou serviços, abarcando toda a cadeia de produção e 
consumo. Considera-se a aquisição de energia, matérias-primas e produtos auxiliares, aspectos dos sistemas de transportes e logística, características da utilização, manuseio, embalagem, marketing, sobras, resíduos e respectiva reciclagem e consumo final.

A análise de ciclo de vida é o método para análise dos sistemas de produto e serviço, considerando os aspectos ambientais do "berço ao túmulo", estabelecendo vínculos entre esses aspectos e categorias de impacto potencial ligados ao consumo de recursos naturais, à saúde humana e à ecologia.

As normas desenvolvidas pela ISO sobre Avaliação do Ciclo de Vida harmonizam os procedimentos adotados nas iniciativas tomadas em vários países do mundo por institutos de pesquisa e empresas interessadas em demonstrar o desempenho ambiental e a aceitação dos produtos no mercado.

O fato de considerar as diferentes etapas do ciclo de vida do produto, desde a obtenção da matéria-prima até a disposição final do produto, faz da ACV um poderoso instrumento de melhoria ambiental, já que abrange questões como a transferência de impactos ambientais de uma etapa do ciclo de vida do produto para outra, ou de um meio para outro, sem que haja um ganho ambiental líquido.

Assim, o conceito de ciclo de vida é um dos pontos centrais da concepção dos programas de rotulagem ambiental e o seu grande diferenciador em relação aos programas que se baseiam apenas em um critério ou em um conjunto limitado de critérios. Por outro lado, ao se implementar a abordagem do ciclo de vida no estabelecimento dos critérios dos rótulos ambientais, o uso da avaliação do ciclo de vida apresenta algumas dificuldades e limitações.

Tais dificuldades estão relacionadas com: a grande extensão dos estudos, os altos custos envolvidos, à necessidade de obtenção de dados que nem sempre estão disponíveis, e ao prazo longo para que resultados sejam alcançados. As dificuldades mencionadas resultariam na inviabilização, pelo menos em muitos casos, do desenvolvimento dos critérios.

A solução para o problema encontra-se no princípio da consideração do ciclo de vida. Com efeito, como já foi referido, é recomendado pela norma ISO14024 que os critérios ambientais levem em consideração o ciclo de vida do produto, sem que haja necessidade de se conduzir uma avaliação completa desse ciclo. Isto é conseguido mediante uma apreciação do ciclo de vida do produto, onde se identificam as fases críticas do ponto de vista dos impactos potenciais, as quais serão objeto de estudos mais aprofundados.

Esta apreciação é efetuada com a participação das partes interessadas que devem validá-la. A consideração do ciclo de vida deve incluir uma avaliação de significância do conjunto dos impactos para embasar a seleção daqueles que serão utilizados na definição dos critérios. O envolvimento das partes interessadas nesta etapa do processo de definição 
de requisitos é a chave para se assegurar que são apropriados e a sua legitimidade. Uma das formas empregadas com esse fim é a da constituição de comitês com representantes dos setores interessados para a condução dos trabalhos, inclusive a consideração do ciclo de vida.

\subsubsection{Ferramentas de avaliação da conformidade}

A avaliação da conformidade diz respeito à atividade com o objetivo de determinar, direta ou indiretamente, que os requisitos aplicáveis são atendidos. Exemplos típicos de atividades de avaliação da conformidade são os ensaios, inspeções e auditorias, garantia da concordância (como declaração do fornecedor e certificação), bem como suas combinações.

Em um programa de rotulagem ambiental, a avaliação da conformidade de um produto, em relação aos critérios estabelecidos, deve ser desenhada recorrendo-se às diversas ferramentas disponíveis, levando em conta os custos envolvidos no processo, eventuais condicionantes tecnológicos, tais como disponibilidade de laboratórios capacitados ou a duração e precisão dos ensaios, aspectos logísticos, como facilidade de coleta e remessa de amostrars, tipo de informação a ser levantada e outros indicativos desse gênero (ABNT, 2010).

Assim, face aos critérios estabelecidos, a avaliação da conformidade será concebida de modo a assegurar um grau adequado de confiança no atendimento aos requisitos com custos compatíveis e viabilidade técnica. Isto significa que determinadas características poderão ser avaliadas mediante ensaios, enquanto para outras, possivelmente, será mais apropriado avaiá-las por meio de inspeções ou auditorias e, para outras, ainda poderá ser aceitável o uso da declaração do fornecedor (ABNT, 2010).

Percebe-se assim que o estabelecimento dos mecanismos de avaliação de conformidade é um processo que, de um lado, requer competência técnica e, de outro, interação com a indústria e demais setores interessados, de modo que, com transparência, sejam selecionados os mecanismos adequados e viáveis. Desta maneira, a determinação dos procedimentos de avaliação da conformidade, em relação aos requisitos, deve incluir também um processo de consulta e aprovação junto às partes interessadas.

\subsubsection{Boas práticas da normalização}

A norma ISO14024 estabelece uma série de prescrições acerca da consulta eda abertura à participação das partes interessadas em todas as etapas da formulação dos critérios de atribuição dos rótulos, bem como da tomada de decisão por consenso. 
Para entender estas prescrições, existem diretrizes estabelecidas em documentos internacionais, como a ABNT ISO/IEC Guia 59 - Códigos de boas práticas para normalização e o anexo do Acordo de Barreiras Técnicas ao Comércio da Organização Mundial do Comércio - Código de boas práticas para a preparação, adoção e aplicação de normas.

Esses procedimentos destinam-se a assegurar a transparência no processo de normalização. Tais medidas incluem, entre outras:

- Publicação dos seus programas de trabalho com antecedência suficiente para que as partes interessadas possam se organizar para participar e contribuir no processo;

- Divulgação e tempo mínimo apropriado dos processos de consulta;

- Consideração dos comentários e sugestões recebidos;

- Tratamento a ser dado a tais comentários e sugestões;

- Publicação e divulgação imediata dos documentos adotados.

Um programa de rotulagem ambiental deve implementar mecanismos e procedimentos que atendam a essas diretrizes, que incluem a definição de critérios, a previsão da constituição de comitês para desenvolver atividades específicas e um processo formal de consulta pública para aprovação dos critérios (ABNT, 2010).

O desenvolvimento de uma estrutura de participação e de consulta às partes interessadas e que não esteja restrita apenas aos atores nacionais é uma condição necessária para o sucesso de um programa de rotulagem ambiental.

\subsection{Programas de rotulagem ambiental}

Não existe uma regra para organizar um programa de rotulagem ambiental. Cada programa é projetado de acordo com as condições e as ambições políticas locais e leva em consideração outros programas existentes, autoridades, condições ambientais, cultura local e suas peculiaridades. O programa de rotulagem ambiental, normalmente é formado por dois grupos de atores: o grupo técnico e o grupo operacional (GEN, 2010).

O grupo técnico elabora normas e regulamentos voluntários enquanto que o grupo operacional, por meio de atividades de marketing trabalha para conscientizar os consumidores e incentivar os produtores a participar dos processos de certificação. Cada grupo tem idéias diferentes da missão da rotulagem ambiental. Geralmente os recursos são divididos da seguinte forma: $40 \%$ para os critérios de desenvolvimento, $40 \%$ para licenciamento e $20 \%$ para administração e marketing. 
O potencial dos programas de rotulagem ambiental para a criação de incentivos de mercado para produtos e processos de produção ambientalmente sustentáveis foi internacionalmente reconhecido na Conferência das Nações Unidas sobre Meio Ambiente e Desenvolvimento (CNUMAD), realizada no Rio de Janeiro, em 1992. A Comissão sobre Comércio e Meio Ambiente (CTE) da Organização Mundial do Comércio (OMC) também reconheceu que programas bem desenhados para rotulagem ambiental podem ser instrumentos de política ambiental eficazes, que podem ser utilizados para promover a consciêntização ambiental entre os consumidores.

A Organização Internacional de Normalização (ISO) desenvolveu princípios gerais e diretrizes para rótulos e declarações ambientais e reconheceu o valor potencial de um programa de rótulagem ambiental bem elaborado enquanto que a União Européia desenvolveu seu próprio programa de rotulagem ambiental denominado " $A$ flor" para 0 mercado interno como uma ferramenta eficaz de política ambiental.

Ressalta-se que em 1996, foi criada a Rede Global de Rotulagem Ambiental (GEN) em um esforço para fortalecer o desenvolvimento de programas nacionais de rotulagem ambiental e promover a harmonização das normas internacionais e do reconhecimento mútuo entre programas de diferentes países. Os diversos membros do GEN representam programas de rotulagem ambiental, nacionais e regionais, que vêem a rotulagem ambiental com potencialidade para influenciar as questões ambientais relacionadas com o consumidor.

A rotulagem ambiental foi adotada pela comunidade internacional como uma ferramenta que pode contribuir para melhorar a gestão ambiental por meio do mercado. Teoricamente, o conceito de rotulagem ambiental recebe interesse e apoio da comunidade internacional e torna-se importante aproveitar o potencial de sinergia para criar programas que objetivam os melhores resultados.

$\mathrm{Na}$ maioria dos programas de rotulagem, os critérios usados para determinar a elegibilidade de um produto para o selo são feitos de modo que apenas uma minoria, aproximadamente $20 \%$, dos produtos da categoria consiga obter o selo. Isto estimula o setor produtivo a se esforçar continuamente a melhorar suas práticas ambientais, já que os critérios se tornam gradualmente mais rigorosos, à medida que a tecnologia avança e permite meios de produção menos impactantes ao meio ambiente.

Para a construção e para a adoção de um rótulo ambiental, assim como para sua implementação precisam ser efetuados os seguintes estudos técnicos e científicos:

i) Pesquisa de implantação - visa identificar a família de produtos e serviços e gerar uma valoração do balanço termodinâmico de troca de matéria e energia; 
ii) Análise dos impactos ambientais - propiciará a avaliação dos impactos ambientais das trocas de matéria e de energia entre o sistema de produção e o ambiente natural;

iii) Metodologia de critérios - são adotados os critérios para a concessão do rótulo ambiental. É necessária uma clara definição dos aspectos metodológicos de avaliação da conformidade e da tecnologia disponível, contemplando o uso do recurso natural e a relevância para a população local, nacional, regional e global, com vista a atingir a excelência ambiental;

iv) Submissão à consulta pública - consiste em submeter à opinião da sociedade a fim de obter consenso em relação à adoção de boas práticas ambientais; comitê de aprovação, em que exercerá o papel de julgamento e encaminhamento das proposições estudadas, julgadas e submetidas ao público alvo;

v) Encaminhamento de critérios - consiste na aprovação pela ABNT dos critérios acordados para a concessão do selo ambiental; e

vi) Revisão de critérios da logomarca ambiental - refere-se aos aspectos metodológicos para a revalidação e continuação no uso da logomarca ou do selo ambiental já concedido.

Esse processo de concessão e avaliação de rotulagem, logomarca ou selo ambiental tem uma proposição de distribuição de tarefas, as quais são alocadas organizacionalmente, em que uma agência (A) previamente escolhida é responsável pela etapa da pesquisa, do impacto e da metodologia; uma comissão julgadora (J) constituída de notáveis conhecedores da biodiversidade nacional é formada, cuja incumbência é fazer o julgamento dos critérios e conceder o selo; e um instituto técnico (I), com o objetivo de assessoramento quanto a submissão de consulta pública, encaminhamento de critérios aos órgãos competentes e revisão de critérios de concessão de logomarca ou selo concedido (IPEA, 2011).

\subsubsection{Princípios orientadores de programas da rotulagem ambiental}

Com base nas experiências bem sucedidas de programas de rotulagem ambiental existentes e no trabalho pertinente da ISO, alguns princípios podem ser identificados como sendo fundamentais para um programa de rotulagem ambiental eficaz e crível. Pode-se destacar: 


\subsubsection{A participação voluntária}

A decisão dos fabricantes, dos importadores, dos prestadores de serviços e de outras empresas em relação à participação em um programa de rotulagem ambiental deve ser voluntária. Os programas devem ser projetados e operados de forma que os potenciais participantes da indústria e de outras partes interessadas possam solicitar que categorias e critérios do Rótulo Ambiental sejam desenvolvidos para seus produtos.

\subsubsection{Cumprimento da legislação ambiental e de outras legislações pertinentes}

Uma contribuição fundamental para a credibilidade de um programa de rotulagem ambiental é a natureza e a extensão dos requisitos que são necessários para participação no programa, tanto específicos do produto quanto em condições mais gerais.

Embora o foco principal dos critérios de rotulagem ambiental se relaciona com os aspectos ambientais e de desempenho de um produto que está sendo oferecido, é importante abordar a conformidade regulatória do produtor de um produto ou da instalação do provedor de um serviço que estão sendo oferecidos.

Torna-se necessário que um componente básico da indústria líder ambiental esteja em total conformidade com as exigências legislativas ambientais e com outras legislações relevantes. Sugere-se que os requisitos de conformidade sejam uma condição de licenciamento para a participação no programa, em vez de um critério de conformidade do produto.

A abordagem exige o cumprimento da legislação aplicável em escala local e/ou regional e reconhece os diversos requisitos regulatórios que podem existir em diferentes jurisdições e evita impor obstáculos percebidios como desnecessários ao comércio para os candidatos de programas ambientais estrangeiros.

\subsubsection{Apreciação de "adequação à finalidade" e nível de desempenho geral}

Além da conformidade legislativa, é também importante considerar a qualidade e o desempenho de um determinado produto que está sendo considerado para receber o rótulo ambiental. A credibilidade do rótulo ambiental e a do programa de rotulagem ambiental podem ser prejudicadas caso os produtos que ostentam o rótulo ambiental não demonstrem qualidade e desempenho razoáveis em relação às alternativas similares que estão no mercado.

Pesquisas e estudos de mercado e de consumo têm mostrado que os atributos ambientais são apenas um dos fatores considerados pelos consumidores em suas decisões 
de compra, e normalmente só são contabilizados quando a qualidade e o desempenho são comparáveis e estabelecidos.

São baseados em sólidos princípios científicos e de engenharia

A manutenção de rigorosos requisitos técnicos e baseados na ciência ambiental garante aos consumidores que eles podem confiar no rótulo ambiental e em um tratamento justo no processo de licenciamento. Além disso, os critérios ambientais de produtos devem ser baseados em indicadores resultantes de considerações sobre o ciclo de vida do produto.

A lógica é que há uma crescente percepção geral de que é necessário assegurar aos consumidores, aos produtores e aos prestadores de serviços, que todos os aspectos de desenvolvimento de um produto, do fornecimento, da utilização e do descarte foram levados em consideração.

Critérios devem distinguir a liderança

Os critérios devem ser desenvolvidos e aprovados de tal forma que possa distinguir claramente um segmento de liderança dentre as categorias de produtos em análise. Ressalta-se que é importante determinar o adequado ponto de corte para se evitar a arbitrariedade e a elaboração de critérios irrelevantes de liderança.

Critérios devem ser críveis, relevantes, possíveis e verificáveis.

A consideração de rigorosos requisitos técnicos e científicos garante a confiança dos consumidores no rótulo ambiental e em um tratamento justo no desenvolvimento do processo de licenciamento. Além disso, os critérios ambientais de produtos devem ser baseados em indicadores resultantes de considerações sobre o ciclo de vida do produto.

A possibilidade de uma avaliação do ciclo de vida completo pelos programas deve ser considerada para assegurar aos consumidores e aos produtores que todos os aspectos do ciclo de vida de um produto foram levados em consideração.

No entanto, os critérios também devem ser práticos em termos de ser atingíveis, inicialmente para um segmento de mercado líder e ser expresso em unidades mensuráveis que podem ser verificadas. Em outras palavras, os critérios devem ser aceitáveis, razoáveis e úteis para os programas de rotulagem ambiental poder licenciar os produtos, para as entidades encarregadas de verificar a conformidade com os critérios, para os consumidores, para os compradores e para outras partes interessadas. 


\subsubsection{Independência}

Um programa de rotulagem ambiental crível deve ser operado por uma organização independente de interesses comerciais e de outros direitos adquiridos. A Independência do programa também se estende à forma como categorias de produtos e os critérios de adjudicação ambiental são determinados.

Normalmente, isso é feito por meio de representação formal e direta de diferentes atores e grupos interessados em escritórios independentes, painéis de discussão ou grupos de aconselhamento. Os conselhos, painéis ou grupos geralmente, incluem membros da indústria, do ambientalismo, dos consumidores, da academia e da ciência além de setores do governo.

O desafio é buscar algum grau de representação equilibrada de modo que não exista qualquer influência excessiva exercida por setores específicos ou a prevalência de interesses individuais das partes interessadas.

Processos abertos e responsáveis

Um programa crível deve basear-se em um processo aberto e responsável, que pode ser observado, monitorado e questionado a qualquer momento. Em cada etapa do processo devem ser estabelecidos procedimentos justos, consistentes e aplicados de forma uniforme. Um bom sistema de gestão da qualidade é um trunfo forte e altamente desejável.

Além disso, a revisão pública de critérios é uma característica essencial de um processo aberto. Alguns programas anunciam publicamente novos critérios de projetos por meio de redes de informação da mídia e do governo. Outros realizam audiências públicas ou estabelecem contato direto com grupos interessados solicitando comentários. Os comentários recebidos são considerados na elaboração dos critérios finais. Revisão periódica, geralmente a cada três anos, garante que os níveis das normas e dos critérios sejam harmonizados com os novos avanços.

\subsubsection{Coerência com ISO 14020 e ISO 14024 princípios orientadores ou outras legislações apropriadas}

A aceitação e a adoção de uma série de normas da ISO 14000, por parte da indústria e por parte dos governos continuam a aumentar em todo o mundo e pode tornar-se vantajoso para os programas de rotulagem ambiental demonstrar coerência com os princípios orientadores contidos nas relevantes normas de rotulagem ambiental ISO (Quadro 3.7 e Quadro 3.8) 
QUADRO 3.7 Princípios orientadores para rotulagem ambiental (rótulo Tipo I - ISO 14020)

\begin{tabular}{|l|}
\hline Precisão; \\
\hline Evitar barreiras comerciais desnecessárias; \\
\hline Bases científicas; \\
\hline Prestação de informações sobre a metodologia; \\
\hline Abordagem do ciclo de vida; \\
\hline Promoção da Inovação; \\
\hline Encargos administrativos mínimos; \\
\hline Processo aberto e consensual; \\
\hline Fornecimento de informações sobre produtos \\
\hline
\end{tabular}

Fonte: GEN, 1999

QUADRO 3.8 Princípios Orientadores para programas de rotulagem ambiental-ISO 14024

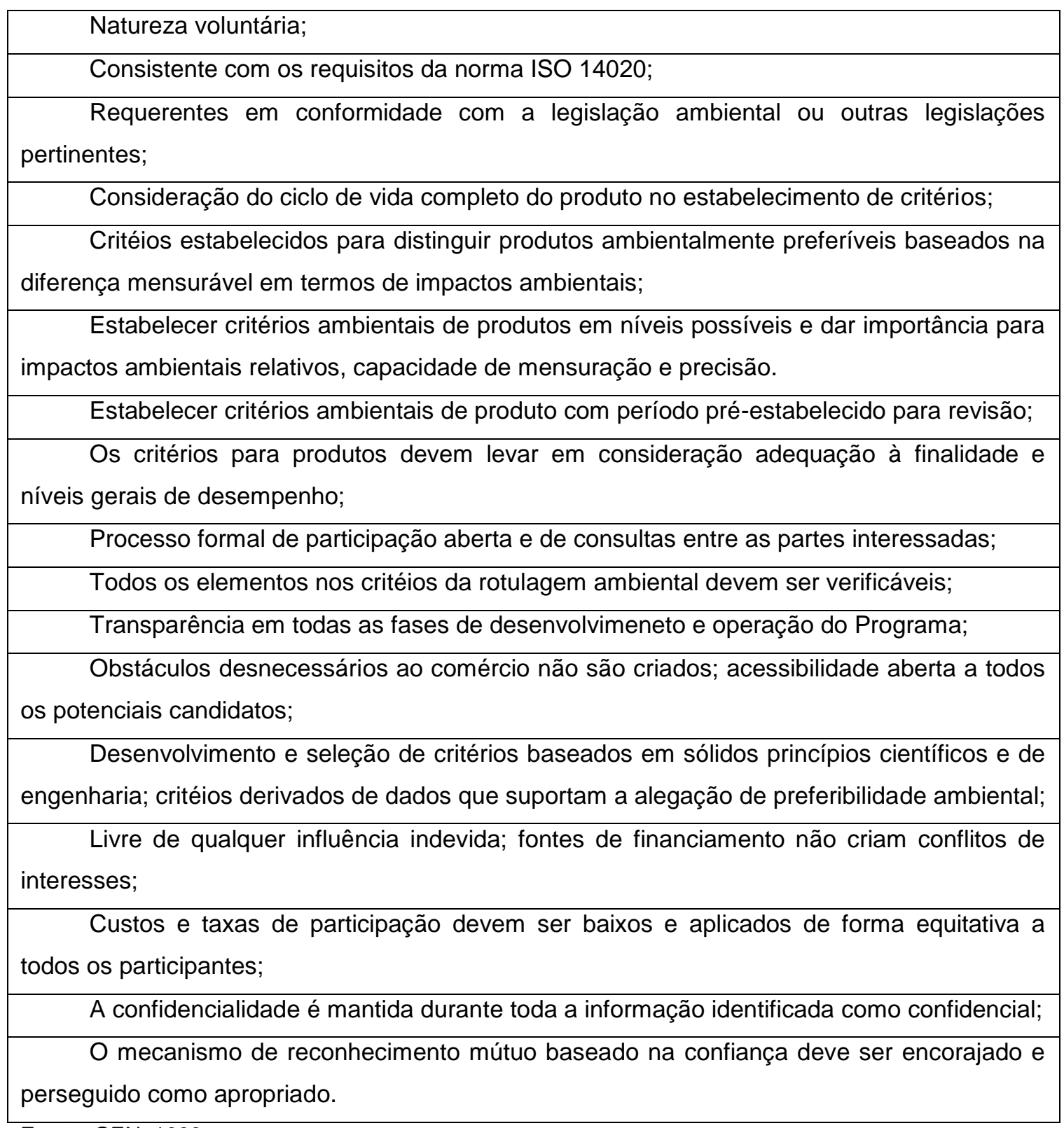

Fonte: GEN, 1999 
Essa coerência pode proporcionar maior legitimidade e solidez para os Programas de Rotulagem Ambiental em vigor e em desenvolvimento. Adicionalmente, a rede global de rotulagem ambiental: Global Ecolabelling Network (GEM) está elaborando um documento (Roadmap) com princípios orientadores para o desenvolvimento, a gestão e a operação de programas ou esquemas de rotulagem ambiental.

\subsubsection{Principais parceiros dos programas de rotulagem ambiental}

A ampla participação das partes interessadas em qualquer iniciativa de rotulagem ambiental é essencial para o seu impacto e sucesso global e geralmente envolve os seguintes grupos:

\subsubsection{Governo}

Muitos programas são iniciados e financiados por Departamentos ou Agências governamentais. Além de fornecer o input, direta e / ou indiretamente, no desenvolvimento do programa, nas áreas de gestão e de entrega, o governo em diferentes níveis, pode influenciar e demandar de forma significativa por meio de suas iniciativas e atividades de aquisição.

\subsubsection{Autoridades de gestão do programa}

Um grupo independente normalmente supervisiona e dirige as atividades de execução do programa, por exemplo, aspectos técnicos, de marketing e administrativos. O nível de envolvimento pode variar de programa para programa e no que diz respeito às funções de coordenação e articulação entre os diferentes órgãos para a execução das tarefas operacionais rotineiras.

\subsubsection{Indústria e associações comerciais, varejistas e empresas.}

A conscientização, o interesse e o envolvimento direto da indústria e de setores comerciais são essenciais para o sucesso do programa. Os critérios formulados para a certificação e para o licenciamento devem ser críveis e práticos para o mercado. $O$ envolvimento da indústria e dos varejistas é fundamental nesse sentido. 
A orientação da indústria e do setor comercial e o suporte desde o início e em todas as fases do programa são desejáveis. Deve-se reconhecer que a indústria representa os produtores de bens e prestadores de serviços, bem como as entidades adjudicantes.

\subsubsection{Consumidores}

A demanda dos consumidores, seja em residências, em instituições ou nas empresas, gera impacto no mercado. Exigências e preferências dos consumidores devem ser determinadas, reconhecidas e levadas em consideração em várias iniciativas e resultados do programa.

\subsubsection{As partes interessadas}

A credibilidade de um programa pode ser melhorada através do envolvimento e apoio de várias organizações, grupos e indivíduos que não possuem interesse comercial direto na rotulagem ambiental. Por outro lado, a omissão de tais grupos pode comprometer a confiança e a aceitação do público.

\subsubsection{Academia}

A incorporação da pesquisa e da perícia de ponta nos processos de desenvolvimento de critérios e de avaliação pode melhorar a qualidade, a relação custo-eficácia e a eficiência dos resultados.

\subsubsection{Mídia}

Grupo importante para a promoção do rótulo ambiental para os consumidores e para a indústria.

\subsubsection{Comunidade Internacional}

Esta ampla categoria pode incluir consumidores estrangeiros, representantes e participantes da indústria, e outros potenciais interessados não domésticos como: pesquisadores, representantes da mídia, ONGs e representantes governamentais. Com a globalização dos mercados surgiu uma exigência crescente de programas de rotulagem ambiental para expandir seus esforços de consulta para além das fronteiras nacionais. 


\subsubsection{Visão global das etapas principais}

A gestão de um programa de rotulagem ambiental exige conhecimento e compreensão das prioridades ambientais que serão consideradas e tratadas por meio do programa. As atividaddes de um programa de rotulagem ambiental, geralmente envolvem três etapas básicas:

1. Seleção e determinação de categorias de produtos;

2. Desenvolvimento e adoção de critérios, normas ou diretrizes apropriadas, incluindo o desenvolvimento, a revisão pública e a finalização e;

3. A certificação e o licenciamento, incluindo a aplicação, os testes, a verificação e a licença de emissão.

\subsubsection{Seleção e determinação de categorias de produtos}

A seleção de categorias é uma parte crítica do processo de rotulagem ambiental, uma vez que tem um impacto importante sobre a elegibilidade de produtos específicos. $A$ extensão da categoria também pode determinar o rigor dos critérios para a certificação. Por exemplo, no caso de baterias, a abordagem será diferente se forem consideradas todas as baterias, em vez de apenas considerar as recarregáveis. Na medida do possível, o fator determinante é, normalmente, a inclusão de todos os produtos que habitualmente desempenham a mesma função.

As propostas de categorias de critérios para certificação são geralmente aceitos de qualquer fonte. Na prática, a maioria das propostas surge da indústria, ou internamente por parte dos gestores do programa. Organizações de Comércio, do consumidor, do meio ambiente, e outras organizações públicas também podem solicitar a consideração de categorias específicas.

Após a revisão formal, muitas vezes com grupos de consultores técnicos, as seleções são feitas. A maioria dos programas também têm alguns princípios orientadores para auxiliar na seleção. Estes incluem muitas vezes o impacto ambiental do produto, o grau de diferenciação entre os produtos na categoria proposto, e a importância do produto no mercado.

\subsubsection{Desenvolvimento e adoção de critérios, normas ou diretrizes apropriadas.}

Uma vez que as categorias de produtos são selecionadas, os requisitos que o preponderante deve cumprir para ser aprovado pelo programa de rotulagem ambiental 
devem ser estabelecidos. Especialistas técnicos e científicos, geralmente do governo e do setor privado, elaboram critérios de projetos que são, então, colocados à disposição dos interessados para análise e realimentação.

Os comentários são recebidos e analisados pela equipe do programa, por especialistas técnicos ou por um grupo consultivo, e são consideradas, quando for o caso, nos critérios finais.

A complexidade e as limitações da metodologia de avaliação do ciclo de vida completo levaram ao uso de métodos relativamente simples e menos abrangentes de avaliação de desempenho ambiental. Depois de uma análise do ciclo de vida de um produto, os programas geralmente se concentram em alguns atributos-chave como: conteúdo reciclado, toxicidade reduzida, redução da poluição, eficiência energética e capacidade de reciclagem e avaliam o desempenho da indústria nestas áreas escolhidas.

Não importa o método de análise; a seleção de critérios de certificação é uma tarefa difícil. Cada programa quando usa a avaliação do ciclo de vida faz de forma diferente e como nenhum deles faz uma avaliação completa, todos estão sujeitos a desafios visto que a seleção de critérios está baseada em um número limitado de atributos.

Soma-se a essa preocupação, a necessidade de comparar e dar valor a diferentes tipos de impactos. Estudos de estratégias e práticas de rotulagem ambiental levantaram importantes questões relacionadas com essas preocupações. Se, por exemplo, um novo método de produção reduz significativamente a poluição da água, mas ao mesmo tempo aumenta a utilização de combustíveis fósseis e as emissões atmosféricas, pode-se dizer que o novo método é mais sustentável que o antigo?

Como se podem comparar os impactos que ocorrem hoje, com aqueles que são esperados no futuro? O método econômico padrão de descontar futuros custos e apropriar os ganhos é adequado em relação a questões ambientais?

Apesar destas dificuldades, há uma tendência de avançar para avaliações mais abrangentes do ciclo de vida e para uma cooperação mais estreita entre os programas de rotulagem ambiental com o objetivo de harmonizar critérios. E elaborar critérios comuns. Além disso, gestores de programas de alguns países optaram pela concentração em um número limitado de critérios ambientais considerados fundamentais.

Em alguns casos específicos, programas particulares oficiais programaram e aplicaram os métodos de ponto de carga. Em tais sistemas, os pontos são concedidos de acordo com o nível de cumprimento de determinados critérios estabelecidos em vez de exigir dos proponentes que cumpram todos os requisitos.

Os candidatos que atingiram uma determinada pontuação tornam-se elegíveis para a certificação. Apesar de esse tipo de sistema trazer preocupações em relação à demasiada 
flexibilidade sobre as questões de proteção ambiental ele dá ao potencial proponente maior alcance no desenvolvimento de métodos para reduzir o stress ambiental.

\subsubsection{A certificação e o licenciamento}

Quando os critérios de certificação são estabelecidos, os proponentes, como os fabricantes, os fornecedores, os distribuidores, os importadores e os prestadores de serviços que decidem participar de um determinado programa e tem os seus produtos em conformidade com os critérios definidos, podem solicitar a certificação no âmbito do programa.

Este processo envolve a verificação de conformidade e testes, licenciamento e monitoramento. Os candidatos são geralmente obrigados a apresentar informações técnicas como: relatórios de ensaios prova de conformidade com a lei / regulamentação, prova de um sistema de gestão da qualidade para concluir o processo.

Além disso, o organismo de execução pode dirigir e/ou realizar uma auditoria no local da inspeção. Em alguns casos, a verificação independente é realizada pelo programa, e em outros, uma declaração do requerente é aceita no pressuposto de que os concorrentes ou grupos ambientais notificarão os funcionários do programa se houver uma suspeita de que informações imprecisas foram fornecidas.

Os candidatos geralmente pagam uma taxa de inscrição e arcam com os custos de verificação. Uma vez que o requerente está licenciado para usar o rótulo ambiental em um produto ou serviço, uma taxa anual de utilização é cobrada. Requisitos de certificação e custos devem ser cuidadosamente planejados, a fim de não discriminar alguns segmentos da indústria, nomeadamente as pequenas e as médias, que podem encontrar dificuldades para participação no programa.

A licença ou logotipo é concedido para os produtos que são comparativamente menos prejudiciais do que os produtos competitivos similares. Os programas geralmente são projetados para que os produtos rotulados representem entre 10 e 30\% de participação no mercado na categoria de produtos considerada. Ressalta-se que esse trabalho analisa os rótulos positivos que são orientados para o varejo que é o tipo de rotulagem ambiental que contribui para que os consumidores escolham suas preferências no mercado.

\subsubsection{Mensurando a eficácia do programa de rotulagem ambiental}

Qual é a eficácia do Rótulo Ambiental no alcance de seus objetivos? Como o sucesso pode ser medido? Como a maioria dos programas nacionais de rótulagem 
ambiental foram estabelecidos há pouco tempo, os esforços para medir a eficácia desses programas estão incompletos.

No entanto, as respostas positivas de indústrias e de consumidores sugerem que os rótulos ambientais são percebidos como ferramentas efetivas de marketing e como símbolos de escolhas ambientalmente saudáveis do consumidor.

Dada a dificuldade em separar o impacto da rotulagem ambiental de outras políticas econômicas, ambientais e sociais, alguns programas tentaram alegar benefícios ambientais diretos do rótulo ambiental. Os esforços feitos na direção da mensuração da eficácia dos programas de rotulagem ambiental em geral, consideram indicadores como: os avanços da qualidade ambiental dos produtos certificados, a participação da indústria no mercado e o reconhecimento dos consumidores.

\subsubsection{A melhoria da qualidade ambiental dos produtos certificados}

Ao longo do tempo, o sucesso de um programa de rotulagem ambiental é parcialmente demonstrado por meio de critérios ambientais mais rigorosos para os produtos. A maioria dos envolvidos na rotulagem ambiental reforça a necessidade de programar períodos regulares de revisão de critérios e de processos de análise para abordar os avanços tecnológicos e do mercado, especialmente para as categorias de produtos em que existam produtos licenciados e certificados.

A participação da indústria no mercado

Um programa de rotulagem ambiental é um instrumento de política voluntária, que usa o mercado, em vez da regulamentação, para atingir metas ambientais. Precisa oferecer algo mais para incentivar as empresas a participar do processo de certificação.

Os produtores e prestadores de serviços devem ter certeza de que fazer parte do programa irá melhorar a sua situação no mercado e/ou melhorar a sua imagem corporativa. Aspectos de credibilidade são importantes para as empresas assim como uma estrutura de taxas razoáveis, avaliação justa, e não discriminação das empresas baseadas no tamanho, na localização, no faturamento ou em outros fatores.

Ao mensurar a participação da indústria, a maioria dos programas de rotulagem ambiental relata um aumento substancial e contínuo tanto nas categorias de critérios quanto nos produtos certificados em relação aos critérios. O crescimento isolado apenas das categorias, porém, pode não ser um indicativo do interesse da indústria, dado que algumas categorias pode não ter muitos, ou mesmo nenhum produto licenciado. 
Por outro lado, um aumento nos produtos certificados indica que os produtores e/ou os prestadores de serviços vêem vantagem em exibir o rótulo ambiental. Pesquisas com os consumidores testemunham uma preferência consistente para os produtos que são percebidos como ambientalmente sustentáveis.

Apesar de o foco do consumidor poder mudar de um critério para o outro, por exemplo, a partir de embalagens, da eliminação de substâncias tóxicas, da preservação de animais selvagens, a propensão de grande parte dos consumidores para escolher produtos verdes e pagar um prêmio por eles tem sido regularmente confirmado (GEN, 2004).

No entanto, as pesquisas também mostraram que o desempenho ambiental superior de um determinado produto só se torna um fator competitivo efetivo quando o desempenho do produto, a qualidade e seu valor foram estabelecidos.

Um número crescente de produtos licenciados é outro indicador de sucesso. Outros indicadores de sucesso relacionados com a participação da indústria são os números de desistências voluntárias e de casos de não conformidade. Quanto mais bem-sucedido for um programa, maiores serão os custos potenciais para a empresa, associados com a não participação ou a perda da licença já adquirida.

Outro indicador percebido pelos programas é a revogação de uma determinada norma sobre critérios de certificação devido à melhoria global da indústria tornando os critérios inicialmente desenvolvidos inadequados ou desnecessários. Outro indicador é o envolvimento global da indústria na seleção das categorias de critérios, no desenvolvimento e na avaliação de critérios, e nas atividades de marketing que incorporam um rótulo ambiental.

\subsubsection{A demanda e o reconhecimento do consumidor}

A demanda e o reconhecimento dos consumidores são fundamentais para o sucesso de um programa de rotulagem ambiental. Sem evidências de que o programa promove suas atividades e suas licenças e de que os consumidores reconhecem e confiam no rótulo ambiental, é difícil de mobilizar e manter a participação da indústria no processo.

São necessários vários anos para se construir a confiança dos consumidores e da indústria. Uma das principais tarefas é a de garantir que as informações sobre o rótulo ambiental e sobre os produtos certificados efetivamente cheguem aos consumidores. Acompanhar o reconhecimento do consumidor tem sido uma característica importante de muitos programas de rotulagem ambiental.

Pesquisas indicam que o reconhecimento também implica em confiança e a possibilidade dos consumidores serem motivados a tomar decisões de compra com base 
em sua crença compartilhada de que o produto escolhido causará menos danos ambientais do que seus concorrentes.

O envolvimento e o apoio de ONGs ambientais, de organizações de consumidores e dos meios de comunicação são fatores-chave que contribuem efetivamente para aumentar o nível de conscientização dos consumidores em relação aos produtos ambientalmente sustentáveis em determinados países.

Em países onde a concscientização dos consumidores sobre as questões ambientais é baixa, pode ser difícil convencer as empresas de que existem vantagens a serem obtidas a partir da obtenção de um rótulo ambiental. Isto sugere que a formação inicial de um trabalho pode ser necessária antes de, ou concomitante com a introdução da rotulagem ambiental.

Mesmo em países com um alto grau de consciência ambiental, iniciativas têm sido tomadas para promover o rótulo ambiental e os produtos rotulados. Muito além do reconhecimento do rótulo ambiental, a demanda do consumidor é um indicador-chave de sucesso.

Impactos maiores também são realizados quando os critérios de rotulagem ambiental são usados como ferramentas de orientação para identificar os produtos mais ambientalmente sustentáveis para aquisição de compras governamentais e de compras institucionais. Embora os resultados da pesquisa de opinião possam ser úteis na avaliação da demanda, os registros de padrões de compra são um meio mais preciso.

\subsection{Considerações sobre o programa de rotulagem ambiental da União Européia Ecolabel - Flower}

A rotulagem é um dos instrumentos centrais do Plano para Produção e Consumo Sustentável da União Européia. Nas suas origens, o projeto de rotulagem foi impulsionado por duas prerrogativas: o impacto social e a função econômica. Ao contrário de outras ferramentas de gestão ambiental, a rotulagem ambiental consciente é um conceito recente e, não carrega o peso de instrumentos econômicos antigos (UNEP, 2009).

A definição, os limites, e o potencial de impacto foram estabelecidos por meio da interdisciplinaridade sociológica e pela literatura econômica dentro das quais foi recentemente abordada. O esquema do Programa de Rotulagem Ambiental da União Européia tem suas origens em 1987, quando o Parlamento Europeu como parte das comemorações do primeiro ano europeu para o meio ambiente, recomendou a criação de um rótulo comunitário europeu para produtos ecológicos (CORREA, 1998).

Posteriormente o Conselhho da União Européia solicitou à Comissão apresentar uma proposta de esquema comunitário de rotulagem ambiental. O Programa comunitário foi 
então, aprovado pelo Conselho em 23/03/1992 por meio do Regulamento n. 880/921, com o objetivo de promover o design, a produção, a comercialização e o consumo de produtos com reduzido efeito ambiental durante o ciclo de vida e informar os consumidores, de forma efetiva, sobre o impacto dos produtos no meio ambiente (CORREA, 1998).

Importante ressaltar que a iniciativa pretendia, sobretudo, evitar a concorrência entre os diferentes programas ambientais adotados individualmente por seus Estados-Membros, procurando instrumentalizar um esquema que uniformizasse os critérios para o sistema de atribuição, aplicáveis em toda a União Européia. O Regulamento admite a continuidade de programas nacionais de selo ambiental e até a implementação de novos esquemas, mas afirma que seu objetivo é o de criar condições para a adoção de um único rótulo ambiental em toda a União Européia.

O logotipo compõe-se de uma flor com as doze estrelas da União Européia ao invés de pétalas (em azul), com um "e"curvo (em verde), que pretende representar tanto a letra "c"de Comunidade com a letra "e"de environment, simbolizando sua interação. À semelhança de outros programas de rotulagem ambiental tipo I, o rótulo ambiental da União Européia opera numa base voluntária por parte dos produtores e distingue produtos ambientalmente sustentáveis por meio da anexação de um rótulo (a flor) na embalagem desses produtos, conforme figura abaixo.

Figura 2 Rótulo Ambiental da União Européia

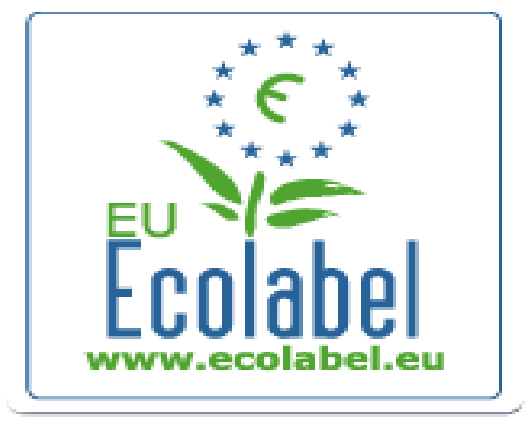

Fonte: www.ecolabel.eu

Tendo em vista constituir-se programa aplicável em todos os Estados Membros, sua estrutura e funcionamento apresentam características próprias e necessárias ao caráter regional de sua implementação. As partes integrantes dessa estrutura administrativa são a Comissão da União Européia, o Fórum Consultivo, os órgãos competentes na implementação do progrma em cada país-membro, o Comitê dos órgãos competentes e o Comitê Regulatório.

A Comissão da União Européia é o centro da atividade do programa, a quem compete decidir sobre as categorias de produtos a serem consideradas e a decisão final 
formal sobre os critérios para a concessão do selo. O Fórum consultivo constitui o órgão assessor da Comissão. Cada país-membro indicou até duas instituições como órgãos competentes para a implementação do programa. O Comitê dos órgãos competentes é integrado pelos representantes de cada uma dessas entidades nacionais e presidido pela Comissão Européia (UNEP, 2009).

Já o Comitê Regulatório dos Estados-Membros é responsável pela aprovação final de critérios propostos para categorias de produtos, ad referendum da Comissão, e pela decisão sobre eventuais objeções feitas por órgãos competentes à solicitação de produtores para a concessão do selo.

Critérios para produtos específicos passam por processo de revisão e de aprovação e são aprovados pelos representantes dos Estados-Membros competentes e representantes da Comissão da União Européia. Os Critérios aceitos são considerados válidos para um período de 3 a 5 anos e após este período, os critérios são modificados e tornados mais rigorosos para refletir os avanços da tecnologia e da capacidade da indústria (Comissão Europeia 2011).

De acordo com o Regulamento da União Européia 1980/2000, os ojetivos do sistema de atribuição do Flower são;

1. Promover os produtos que têm potencial de reduzir os impactos ambientais negativos, em comparação com outros produtos do mesmo grupo, contribuindo deste modo para a utilização eficiente dos recursos e o alcance de um nível elevado de proteção ambiental e;

2. Fornecer orientação e informações precisas e cientificamente comprovadas para os consumidores para tomar decisões informadas com base no desempenho ambiental de um produto ou serviço.

Para o alcance desses objetivos foram estabelecidos os seguintes princípios:

- Os impactos ambientais dos produtos devem ser identificados com base em uma abordagem de ciclo de vida;

- Participação de salvaguarda em todas as fases de vida de um produto ou serviço quando apropriado;

- $\quad$ Aplicação do princípio pré-cautelar;

- Cumprir a lei, objetivos e instrumentos comunitários e;

- Cooperar com outras iniciativas em matéria de rotulagem da União Européia, como o sistema de rotulagem energética ou o esquema de Agricultura Orgânica.

Ressalta-se que se trata do primeiro projeto multinacional baseado em rótulo ambiental governamental e distinto de programas nacionais e privado. O foco multinacional fez com que o Flower se tornasse a ferramenta central de gestão ambiental do Plano de 
Ação de Produção e Consumo Sustentável da União Européia. No entanto, o referido rótulo tem uma série de características que o distingue de outros sistemas de rotulagem do tipo I.

QUADRO 3.9 Grupo de produtos com critérios estabelecidos para obtenção do Flower

\begin{tabular}{|l|l|}
\hline Sabonetes, champus e condicionadores para cabelo. & Móveis de madeira \\
\hline Detergentes para máquinas de lavar louça & Produtos para jardinagem \\
\hline Detergentes para Lavadora de louças industrial & Suportes para agricultura \\
\hline Detergentes para lavagem manual de louça & Electrodomésticos \\
\hline Roupas & Fontes de luz \\
\hline Produtos têxteis & Bombas de calor \\
\hline Calçados & Aquecedores à base de água \\
\hline Tintas e vernizes & Lubrificantes \\
\hline Equipamentos Eletrônicos & Colchões para cama \\
\hline Equipamentos de imagem & Vasos sanitários e mictórios \\
\hline Computadores pessoais & Produtos de Papel \\
\hline Computadores portáteis & Papel convertido \\
\hline Televisões & Papel para cópia e impressão \\
\hline Revestimentos para pavimentos & Papel para jornal \\
\hline Revestimentos para pavimentos de madeira & Papel impresso \\
\hline Revestimentos duros & Papel de seda \\
\hline Revestimentos têxteis para pavimentos & Alojamento de férias \\
\hline Móveis & Serviços de parques e acampamentos \\
\hline & Serviços de acomodações turísticas \\
\hline
\end{tabular}

Fonte: http://ec.europa.eu/environment/ecolabel/eu-ecolabelled-products-and-services.html (2015)

Tem ampla aceitação governamental no continente europeu, com reconhecimento por parte da União Européia, da Noruega, de Lichtenstein e da Islândia. A supervisão é feita por órgâos de terceira parte e baseada em mecanismos democráticos de política. Adicionalmente, os recursos disponíveis para o programa tanto na implementação quanto na revisão, permite que o rótulo ambiental identifique e avalie com precisão acurada, o impacto ambiental de um produto desde a extração inicial das matérias-primas até o descarte final (Comissão Europeia, 2011).

Finalmente, ao contrário de outros sistemas de rotulagem ambiental Tipo I, o rótulo ambiental da União Européia tem o potencial de criar normas de produção para toda a indústria e para todo o mercado, devido à influência da União Européia como órgão de 
governança. No entanto, objetivo de normas em nível do mercado não tem sido alcançado totalmente e sem dúvida, não deverá ser.

De acordo com a Comissão Europeia, o Flower tem tido um impacto significativo no consumo desde a sua introdução e mais de 300 empresas já submeteram com êxito os seus produtos e serviços para os critérios de atribuição do Flower. Já existem mais de 37.000 produtos com rótulo ecológico da União Européia no mercado. As vendas contabilizam mais de 280 milhões de produtos rotulados o representou em 2004, quase 700 milhões de Euros, em vendas. (EUROBARÔMETRO, 2009)

Atualmente existem critérios aprovados para 37 grupos de produtos e serviços e novos critérios estão em processo de aprovação . Isto inclui o desenvolvimento de critérios para produtos alimentares. Ressalta-se que os critérios de atribuição do Flower só foram desenvolvidos para produtos e serviços não perecíveis, no entanto, é uma questão de considerável controvérsia na comunidade.

Grande parte da motivação para a expansão do rótulo ambiental da UE no sentido de incluir alimentos decorre da evidente importância que os consumidores europeus imprimem à compra de produtos alimentares ambientalmente sustentáveis, da procura por parte dos cidadãos da UE, do apoio da UE dado às iniciativas econômicas eco-friendly, e da relativa invisibilidade do rótulo ambiental da UE (EUROBARÔMETRO, 2009).

Para obter o rótulo ambiental da União Européia, os produtos têm de cumprir um conjunto de critérios que são definidos por um painel de especialistas de várias partes interessadas, incluindo organizações de consumidores e da indústria e que abarcam todo o ciclo de vida do produto em consideração e que incluem as fases de extração de matériasprimas, a produção, a embalagem, o transporte, o uso e o descarte. A abordagem do ciclo de vida garante que os principais impactos ambientais dos produtos sejam reduzidos, em comparação com produtos similares do mercado.

A obtenção do rótulo ambiental da União Européia exige a consecução dos seguintes passos básicos:

Passo 1 - Pedido de atribuição do rótulo ecológico de um produto específico apresentado pelo fabricante, importador, prestador de serviço, comerciante ou varejista para um organismo competente.

Passo 2 - Com base na aplicação e nas informações fornecidas pelo requerente, o organismo competente verifica se o produto está em conformidade com os critérios oficiais e que a aplicação está em conformidade com os requisitos de avaliação e verificação.

Passo 3 - Após verificação final do pedido, o organismo competente celebrará um contrato com o requerente.

Passo 4- O organismo competente notifica a Comissão Europeia sobre o contrato 


\section{Quadro 3.10 Preços cobrados para obtenção do Flower}

\begin{tabular}{|l|l|l|}
\hline Tipo de requerente & Taxa de aplicação (Euros) & Taxa anual (Euros) \\
\hline Micro empresas & 200 a 350 & Máximo de 18.750 \\
\hline $\begin{array}{l}\text { Pequenas e médias empresas } \\
\text { e firmas de países em } \\
\text { desenvolvimento }\end{array}$ & 200 a 600 & Máximo de 18.750 \\
\hline Outras empresas & 200 a 2000 & Máximo de 25.000 \\
\hline
\end{tabular}

Fonte: Fonte: http://ec.europa.eu/environment/ecolabel/eu-ecolabelled-products-and-services.html (2015)

O rótulo ambiental da União Européia foi projetado para ter custo baixo para as empresas que se candidatam à certificação. Os custos de administração variam entre os organismos competentes, entre os países e de um produto para o outro. De forma geral, os preços praticados encontram-se na Tabela a seguir.

\subsection{Implicações do ecolabel}

A ligação entre a filosofia e os projetos concretos de rotulagem da União Européia se caracteriza pela legitimidade. Para que os projetos de rotulagem possam ganhar legitimidade, aos olhos dos consumidores, dos produtores e dos governos, suas suposições subjacentes devem ser aceitas.

A transparência precisa ser aceita como um fator necessário e positivo em um sistema democrático em funcionamento. No caso do rótulo ambiental todas as partes devem acreditar em um dos princípios básicos da modernização ecológica que é a promessa de uma situação onde todos os envolvidos acabam sendo beneficiados (win-win) na qual o melhoramento ambiental e o desenvolvimento técnico-econômico são harmônicos (Orsato e Clegg 2005).

Os cidadãos consumidores europeus têm de acreditar que o meio ambiente pode e deve ser protegido por meio da gestão do ecossistema. Também devem acreditar que os consumidores têm um papel importante nesta gestão do ambiente por meio do seu poder de compra. Além disso, o consumidor é incentivado a sentir o dever como cidadão para promover a causa do consumo sustentável: um bom consumidor é um bom cidadão (Hobson 2010, pg.100). Os pequenos e os grandes produtores devem acreditar que optar por programas de rotulagem resulta em um impacto positivo ou pelo menos impacto negativo não proibitivo sobre seu balanço final.

A ligação entre a retórica, o desenvolvimento e a implementação do projeto pode ser claramente traçada no caso da estratégia de desenvolvimento global da União Européia e os seus programas de rotulagem individuais. $O$ projeto de rotulagem ambiental está 
vinculado à iniciativa emblemática da eficiência dos recursos, que é parte essencial do mandato Europa 2020 sobre o meio ambiente (Comissão Europeia 2010).

O roteiro da eficiência de recursos mostra a macro retórica da Estratégia Europa 2020 em termos do meio ambiente, da economia e do desenvolvimento de projetos, incluindo a rotulagem (Resource Roadmap Eficiência 2011). O documento argumenta que a utilização eficiente dos recursos na União Européia só pode ser alcançada com melhorias tecnológicas, uma transição rumo à transformação significativa da energia, da indústria, dos sistemas agrícolas e dos transportes e principalmente, mudanças no comportamento dos produtores e dos consumidores.

O referido documento sugere que a União Européia deve fazer um esforço considerável para entender melhor o comportamento do consumidor e fornecer melhores informações sobre as pegadas ambientais de produtos, incluindo a prevenção do uso de informações enganosas, e esquemas de melhoramento da rotulagem ambiental. Isso inclui a avaliação das formas de diminuir o impacto ambiental da produção de alimentos e dos padrões de consumo e desenvolver critérios importantes e baseados na sustentabilidade para commodities alimentares até 2014.

Conceitualmente, o programa de rotulagem da União Européia combina formulações políticas e emocionais de rotulagem consciente. A Comissão Europeia sugere que os produtos que ostentam o Flower em suas embalagens devem preencher critérios rigorosos de desempenho, garantindo que os consumidores e os produtores tenham benefícios financeiros e ao mesmo tempo possam contribuir para a proteção do meio ambiente. Ressalta-se aqui a tensão da experiência do consumidor de consumir produtos rotulados da União Européia. Embora o meio ambiente seja efetivamente considerado é a satisfação do cliente que impera.

Para os consumidores, as possíveis implicações negativas do programa de rotulagem da União Européia podem advir de informações incompletas ou enganosas. Em suma, a informação não necessariamente significa transparência e pode levar a uma falsa sensação de segurança e reforma.

De acordo com organização Foodwatch (2008), algumas das críticas mais incisivas sobre o programa de rotulagem da União Européia vêm de observadores ambientais de terceira parte, representantes de organizações do setor de alimentos que afirmam que o referido programa não orienta de forma efetiva os consumidores que querem contribuir para a mitigação das mudanças climáticas. Afirmam que o programa utiliza documentação incorreta sobre a origem das matérias primas utilizadas nos produtos e elabora relatórios incompletos sobre o ciclo de vida de produto.

É importante ressaltar que a Foodwatch não é contrária ao programa de rotulagem ambiental, no entanto, identifica inúmeras lacunas de informação que deveriam estar 
disponíveis pelo programa, para os consumidores e alega que isso prejudica potencialmente, uma reforma efetiva do meio ambiente.

O nicho de mercado dos produtos rotulados é extremamente concentrado e limitado e os preços a varejo são mais elevados que os preços dos outros produtos. A disposição para pagar é mais alta em países onde os consumidores ecologicamente, são mais conscientizados (GROTE, 2002).

A eficácia dos produtos com rótulos ambientais não muda em função dos diferentes níveis de renda das famílias, mas muda em função do nível de educação e do marketing informacional relacionado com o processo. O resultado é que os rótulos ambientais são mais eficazes com as mulheres, com indivíduos com formação universitária e com consumidores jovens, com idade entre 18-25 anos (GRANKVIST, 2002).

Isto mostra um esforço baseado em classes que impossibilita uma participação efetiva de toda a população na direção de uma transformação real e efetiva do meio ambiente. Levando em consideração que os produtos com rotulos ambientais são produzidos e vendidos principalmente para consumidores com alto poder aquisitivo, os programas de rotulagem perpetuam soluções de livre mercado para uma eco-elite.

As escolhas do consumidor da eco-elite representam mais um avanço rumo ao apocalipse ecológico, a menos que a economia ambientalmente sustentável contribua para a geração de empregos, a criação de riqueza de oportunidades para a melhoria dos sistemas de saúde e de educação para a população menos favorecida (CLIATH, 2007).

As deficiências sobre as informações de impacto ambiental de um produto e o nicho mercadológico criado pelos produtos rotulados foram assinaladas nas conclusões de um relatório de 1999 sobre as taxas de consumo de produtos com rótulos ambientais. A quantidade e abrangência dos critérios ambientais e as evidências de seu cumprimento, não afetaram a possibilidade da compra ou a quantidade comprada.

Os limites do ativismo ambiental do consumidor tornaram-se óbvios. Enquanto os consumidores europeus estavam cientes dos programas de rotulagem da União Européia como meio legítimo para o consumidor exercer o seu ativismo, suas decisões de compra não foram influenciadas pelos detalhes dessa legitimidade.

Os produtos rotulados podem tornar-se apenas mais um bom posicionamento de mercado e, dessa forma, intensificar a competição posicional ou o consumo competitivo dentro da sociedade de consumo. A procura individual por produtos ambientalmente rotulados que, por natureza, não podem ser compartilhados por todos, forçam as pessoas a gastar uma quantidade cada vez maior de tempo e / ou recursos materiais para alcançar ou manter uma determinada posição na hierarquia social. Mais da riqueza que pode ser atingida por todos, paradoxalmente, significa um aumento da riqueza que pode ser atingida apenas por alguns. 
A discussão sobre a eficácia dos programas de rotulagem levanta outra questão fundamental que está relacionada com o fato de que a compra de produtos ambientalmente rotulados não incentiva uma diminuição do consumo. Para Elkington et al (1990) os consumidores que optam por consumismo político por meio da rotulagem são capazes de expressar suas preferências por produtos ambientalmente conscientes, passivamente.

Ao escolher com cuidado, pode-se ter um impacto positivo no meio ambiente sem comprometer significativamente o seu modo de vida de ser um consumidor verde. Isto implica que os consumidores políticos estão convencidos de que eles não precisam mudar drasticamente seu estilo de vida, porque o mercado vai inerentemente ampliar a sua mensagem e criar automaticamente uma reforma.

A falha fundamental dos programas de rotulagem voltados para o consumidor é que ignoram a escala de consumo. As atrações simbólicas exercidas pelos padrões de consumo intensivos em recursos são mais poderosas que as atrações exercidas pelos padrões sustentáveis de consumo.

Dessa forma, o consumo conspícuo é perpetuado. Qualquer tentativa de forçar os cidadãos-consumidores a consumir menos seria contra os princípios do liberalismo que se desenvolveu ao longo da trajetória histórica do consumo como um projeto político e social no seio da União Européia (Hobson 2010). Para os consumidores europeus, para os produtores, e para os formuladores de política, a diminuição do consumo não faz parte da agenda.

O programa de rotulagem da União Européia têm implicações significativas para o equilíbrio entre pequenos produtores e grandes produtores. A Comissão da União Européia tem feito esforços consideráveis para tornar acessível para todos os produtores, tanto o processo de certificação quanto o de licenciamento.

No entanto, admite-se que a carga regulamentar caiu principalmente sobre os pequenos produtores que podem não ter os recursos disponíveis para atender aos critérios ambientais rigorosos exigidos na ocasião da certificação ou para pagar a taxa de licenciamento no momento da aplicação e a taxa de uso anual.

O Programa de rotulagem ambierntal da União Européia tem recursos especialmente adaptados para produtres de pequena escala envolvidos na produção ambientalmente consciente. No entanto, ainda existem vantagens significativas para os grandes produtores arcarem com os ônus da certificação. Torna-se necessário, em um momento de transição, disponibilizar assistência técnica para o alcance da conformidade ambiental das micro empresas e das pequenas e médias empresas, particularmente, àquelas com poucos recursos disponíveis para atender aos requisitos necessários para a certificação. 
A implicação dessas dificuldades das pequenas empresas e o consequente acesso restrito aos mercados de produtos rotulados com consciência ambiental pode gerar desequilíbrio no complexo agro-industrial, por exemplo. Sem esquemas oficiais de proteão e de ajuda técnica e financeira para os pequenos e médios produtores, os atores industriais como os fabricantes e os grandes varejistas poderão expandir o controle já generalizado nos mercados de consumo.

Esse processo torna-se um problema quando os prêmios obtidos pelos varejistas não alcançam os produtores. Segue-se que a certificação, cria o risco de empurrar os custos extras do respeito às normas ambientais e sociais para os consumidores, enquanto que os produtores simultaneamente corroem suas margens de lucro.

O programa de rotulagem ambiental da União Européia não aborda a questão da superprodução, ou seja, os produtores que optarem ou não, por ser certificados como ambientalmente amigáveis de acordo com as normas européias, não são incentivados a produzir menos ou alterar a sua produção de forma significativa. Em vez disso, seus produtos simplesmente são canalizados para novos nichos de mercado e o ciclo de crescimento descontrolado continua inabalável.

Em termos de gestão ambiental, o programa de rotulagem da União Européia, certamente, têm o potencial de influenciar a sociedade comercial. No entanto, o potencial de impacto na cadeia de produção em termos de intensa reforma das práticas de ciclo de vida do produto parece ser pouco significativo.

Os programas ambientais, o programa de rotulagem europeu ajusta-se à ampla estratégia para a sustentabilidade, abordando as dimensões econômica, social e ambiental, por meio da promoção da eficiência dos recursos naturais e da transformação dos padrões de produção e de consumo, para outros mais sustentáveis. No entanto, o programa apresenta grave falha na comunicação intra-institucional (WILLIAMS, 2004).

De acordo com o Diretório Geral do Meio Ambiente da União Européia, o comitê organizador do rótulo ambiental da União Européia coordena os seus esforços e informações com outros rótulos ambientais em nível nacional, como o Blue Angel, da Alemanha e o Nordic Swan, dos países nórdicos, mas não coordena esforços com o Diretório Geral da Agricultura e do Desenvolvimento Rural e nem com o comitê do rótulo orgânico da União Européia, por exemplo.

Essa situação parece estar mudando já que a pressão para que o rótulo ambiental da União Européia inclua produtos agrícolas, também está aumentando. A partir de 2011, a coordenação entre os dois programas de rotulagem começou a ser harmonizada por meio da elaboração conjunta de um roteiro comum para a eficiência dos recursos. Representantes do Diretório Geral da Agricultura e do Desenvolvimento Rural e do Diretório Geral do Meio Ambiente foram envolvidos na construção de um roteiro para a eficiência dos 
recursos no âmbito do Plano de Acão para uma economia de base biológica sustentável até 2020.

Importante ressaltar que essa coordenação, ou falta dela, destaca as duas principais diferenças entre os regimes do Rótulo Ambiental e o rótulo orgânico da União Européia: a análise do ciclo de vida versus a avaliação orientada para a produção e o caráter voluntário versus a certificação obrigatória. Por um lado, o rótulo ambiental europeu com a metodologia de análise do ciclo de vida do impacto ambiental de um produto é significativamente, mais eficaz no combate à degradação ambiental do que o rótulo orgânico que priorizou a produção.

Por um lado, a análise do ciclo de vida fornece mais informações sobre todas as etapas da criação e do uso de um produto e pode situá-lo mais precisamente dentro do seu contexto ambiental. Por outro lado, a natureza voluntária do sistema de rótulo ambiental da União Européia faz com que a prestação de contas e a transformação do mercado sejam consideravelmente mais difíceis de serem alcançadas do que com o rótulo orgânico que é obrigatório.

Como regime voluntário, a rotulagem ambiental pode involuntariamente abaixar padrões ambientais por desconsiderar os instrumentos de regulação de alimentos mais inflexíveis, rigorosos e responsáveis. O rótulo ambiental da União Européia não tem aplicação rigorosa, porque enfrenta a oposição da indústria agrícola e dos EstadosMembros que vêem o processo de certificação como muito restritivo. As limitações técnicas de mensuração do impacto ambiental do ciclo de vida dos produtos agrícolas também desempenhou um papel importante no desenvolvimento lento dos mecanismos de aplicação do rótulo

No entanto, o movimento em direção à rotulagem ambiental obrigatória de produtos e baseada na metodologia de análise do ciclo de vida está sendo construído para longo prazo. Ressalta-se que apesar da influência positiva exercida pelo rótulo ambiental e pelo rótulo orgânico da União Européia por serem associados à União Européia, ainda são apenas dois programas, dentre uma grande quantidade de programas de certificação nacionais e multinacionais.

Apesar de existirem muitas oportunidades para coordenação conjunta, estes programas na realidade, competem um com o outro e podem tornar os critérios ambientais menos rigorosos e abrangentes e dessa forma não se tornarem bem sucedidos na consecução de seus objetivos. Um número crescente de rótulos de organizações não governamentais e de rótulos do setor privado são menos rigorosos ou priorizam apenas um componente específico de práticas melhoradas (IFOAM , 2008).

Muitas vezes, a terminologia confusa, os rótulos ambíguos, os logotipos semelhantes, e alegações como "produzidos organicamente" e "eco-friendly", aumentam a 
dificuldade de determinação de quais produtos são baseados em mudanças reais para as relações sociais e ambientais e quais são frutos de auto certificação.

A variedade crescente de símbolos, bem como a integração não uniforme desses rótulos em praças europeias podem tornar o consumidor confuso e fazer com que perca a confiança, que é fundamental, para que o processo seja bem sucedido.

\subsection{A rotulagem ambiental no Brasil}

A primeira iniciativa para o estabelecimento de um selo verde brasileiro data de 1990, quando a Associação Brasileira de Normas Técnicas (ABNT) propôs ao Instituto Brasileiro de Proteção Ambiental, a implementação de uma ação conjunta. Naquele momento, pouco progresso ocorreu, principalmente devido às dificuldades de ordem institucional, à falta de recursos e de coordenação suficiente.

Em 1993 o Brasil estabeleceu seu primeiro programa de rotulagem ambiental desenvolvido com base nas experiências de programas mundiais pela ABNT que é representante da ISO no Brasil. Em 1999, a ABNT criou o Comitê Brasileiro de Gestão Ambiental (ABNT/CB-38), que participa na discussão e desenvolvimento das normas ISO 14000 a nível internacional e na tradução e publicação das normas brasileiras correspondentes.

O programa de Qualidade Ambiental desenvolvido pela ABNT é voluntário, de terceira parte, positivo e concede um rótulo ambiental tipo I, baseado em critérios múltiplos. O programa leva em consideração duas diretrizes básicas: ser desenvolvido de forma adequada à realidade brasileira e ser compatível com modelos internacionais, com o objetivo de auxiliar os exportadores brasileiros na superação de eventuais barreiras técnicas.

Ainda que os programas sigam estruturas diferentes em cada país, a essência da atividade permanece inalterada, ou seja, a de contribuir para a confiabilidade no comércio interno ou externo, por meio de instituições internacionalmente reconhecidas.

Após um período de interrupção, o programa de Qualidade Ambiental da ABNT vem sendo reativado. O programa avança de acordo com a demanda da sociedade para o estabelecimento de critérios de rotulagem ambiental para uma determinada categoria de produtos.

A ABNT vem focando, principalmente, nos setores mais demandados pelo mercado exportador, tais como: papel, cosméticos, tintas, meios de hospedagem, calçados, têxteis, monitores, lâmpadas e detergentes. Já existem critérios desenvolvidos para os setores de couro e calçados, em revisão, papel para cópia e impressão e produtos de higiene pessoal 
de higiene pessoal. Estão em andamento critérios para os setores de tecidos e pneus reformados.

Uma vez que um fornecedor solicita a concessão do rótulo ambiental, a ABNT executa as atividades de avaliação da compatibilidade dos produtos com os critérios estabelecidos. Em seguida, um comitê técnico avalia se o rótulo deve ou não ser atribuído ao produto.

\subsubsection{O programa de qualidade ambiental da ABNT}

O Programa ABNT-Qualidade Ambiental começou a ser estruturado em 1993, após a aprovação de um projeto específico no âmbito do PADCT II do Ministério da Ciência e Tecnologia. O primeiro passo foi o desenvolvimento de uma pesquisa sobre os programas de rotulagem ambiental existentes no mundo para fornecer bases para a formulação de um modelo brasileiro.

O modelo proposto no final da pesquisa segue a norma ISO14024 "Environmental labels and declarations - Type I environmental labelling - Guiding principles and procedures". O referido modelo pressupôs uma estrutura participativa na qual todos os setores interessados puderam manifestar seus interesses e os estudos foram baseados na consideração de análise do ciclo de vida do produto.

Figura 3 Rótulo ambiental da ABNT

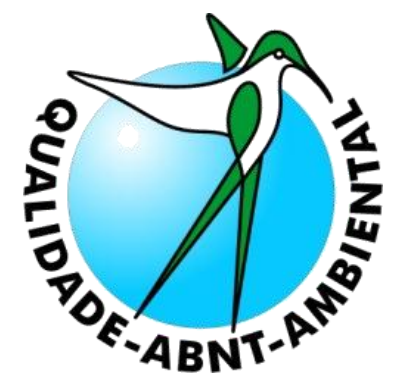

Fonte: www.abnt.org.br

O Programa ABNT-Qualidade Ambiental visa promover a redução dos impactos ambientais negativos relacionados com produtos e serviços, por meio da conscientização de fabricantes, consumidores e instituições públicas sobre a vantagem de adotar produtos que causem o menor impacto ambiental possível, durante o seu ciclo de vida, de acordo com os critérios de qualidade ambiental estabelecidos.

Quando há demanda da sociedade para estabelecimento de critérios de rotulagem ambiental para uma determinada categoria de produtos, caso se verifique a viabilidade técnica e econômica de um novo programa de rotulagem ambiental, a ABNT intitui um 
Comitê Técnico de Certificação, tais como órgãos do governo, representantes de consumidores, associações de indústrias, instituições científicas e tecnológicas, organizações não-governmanetais de meio ambiente, etc.

O comitê é responsável pela execução das atividades que estabelecem os critérios ambientais que envolvem:

1- Estudos Iniciais - Neste ponto são estabelecidos os níveis de detalhes exigidos e os procedimentos que assegurem a qualidade dos estudos. As trocas de energia e matéria entre o sistema de produção e o ambiente são identificadas, levando em consideração o ciclo de vida do produto. Quando for necessário e aplicável, também podem ser consideradas pesquisas internacionais feitas para aquela determinada família de produtos.

2- Avaliação dos impactos ambientais - Nesta etapa são identificados e analisados os impactos ambientais associados às trocas de energia e matéria entre o sistema do produto e o ambiente. O conjunto de impactos sofre uma avaliação de significância, para que sejam identificados aqueles que servirão de base para a definição dos critérios.

3- Estabelecimento dos critérios - De acordo com os resultados dos estágios anteriores, são definidos os critérios para concessão do rótulo e a metodologia de avaliação da conformidade, considerando as questões ambientais relevantes em nível local nacional, regional e global, a tecnologia disponível e a significância desses pontos no contexto da viabilidade econômica, com vistas a promover a excelência ambiental.

4- Consulta pública - Os critérios propostos são submetidos à consulta pública, de modo semelhante ao utilizado na elaboração das normas brasileiras. A proposta final é definida seguindo o processo de consenso de acordo com o Código de Boas Práticas para a Elaboração, Adoção e Aplicação de Normas de Acordo de Barreiras Técnicas ao Comércio da organização Mundial do Comércio e com o Guia 59 do ISSO/IEC - Código de Boas Práticas para a Normalização.

5- Adoção de critérios - Quando os critérios e os procedimentos de certificação são aprovados pelas partes interessadas, são encaminhados à Comissão de Certificação da ABNT para aprovação final.

6- Revisão dos critérios - Cada comitê técnico de certificação define o prazo de validade de critérios, determinando quando devem ser feitas as revisões. Nesta fase devemse levar em conta as evoluções no conhecimento científico, as novoas práticas industriais e as expectativas dos consumidores e de outras partes interessadas.

Concomitante à atividade de estabelecimento dos critérios, a ABNT estabelece a estrutura administrativa do programa, considerando as regras para solicitação do rótulo, contratos-padrão, normas de utilização da marca, etc. 
Uma vez que um fornecedor solicita a concessão do rótulo, a ABNT executa as atividades de avaliação da compatibilidade dos produtos aos critérios estabelecidos. Os relatórios emitidos são anexados aos processos de solicitação e encaminhados ao comitê técnico que avaliará se o rótulo deve ser atribuído ou não. Ressalta-se que os critérios devem ser revisados periodicamente, em função de diversos fatores, como: novas tecnologias, novos produtos nas categorias, novas informações ambientais e alterações do mercado.

Cabe ressaltar que além do programa estabelecido pela ABNT com base na ISO, houve na última década um crescimento significativo de selos verdes no Brasil e que foram estabelecidos por outras certificadoras independentes. Vem sendo largamente utilizados pelo mercado brasileiro, por exemplo, selos referentes à agricultura orgânica com estimativa de mais de 20 selos deste tipo no mercado brasileiro. Os dois principais são os da Associação de Agricultura Orgânica (AAO) e o do Instituto Biodinâmico (IBD) (FAVERIN, 2009).

Em muitos casos, as empresas brasileiras têm procurado diretamente a certificação internacional para suprir a falta de alternativas brasileiras. Por exemplo, o Leadership in Energy and Environmental Design (LEED), sistema norte-americano de certificação de construções sustentáveis, já vem sendo utilizado no país.

Ressalta-se que o programa estabelece normas referentes à redução do uso de água, desempenho de energia e prevenção da poluição na construção, entre outras. No Brasil, o programa gerenciado pelo Green Building Council Brasil incorporou, também, critérios relativos à acessibilidade, incentivo ao aquecedor solar e medição individualizada de água e de luz. Cerca de 140 edificações requereram a certificação no país até 2009 (FAVERIN, 2009).

\subsubsection{Iniciativas governamentais}

O Ministério do Meio Ambiente (MMA) lançou em 2002 as bases para o trabalho do Programa Brasileiro de Rotulagem Ambiental com o objetivo de contribuir para o aumento da demanda por produtos com menor impacto ambiental. O programa também pretendia coordenar e articular as iniciativas brasileiras de rotulagem ambiental por meio de um comitê gestor criado com esta finalidade.

Contudo, esta última iniciativa não apresentou muitos avanços nos últimos anos. A partir de 2009 o MMA vem buscando, por meio da implementação do Plano de Ação para a Produção e Consumo Sustentável retomar a questão, dando maior incentivo à prática da rotulagem no país (BRASIL, 2008). 
O Ministério do Desenvolvimento, Indústria e Comércio Exterior (MDIC) desenvolveu no período de 2006 a 2011, um projeto de cooperação com o Programa das Nações Unidas para o Meio Ambiente (Pnuma) e a União Europeia, visando estimular no Brasil a obtenção do rótulo ambiental europeu Ecolabel, buscando aumentar a competitividade de produtos de exportação brasileiros para a Comunidade Européia, visto que, até aquele momento, nenhum produto nacional possuia o Ecolabel.

O projeto também desenvolveu roteiros para o reconhecimento mútuo de programas nacionais de rotulagem ambiental, além de estimular a sustentabilidade ambiental dos processos produtivos e promover a demanda de produtos certificados no país. O setor escolhido para ser trabalhado foi o de papel e celulose, devido às exportações significativas para a União Europeia e à relevância do setor para o Brasil (JULIANI, 2010).

Contudo, ressalta-se que o Brasil, ao apoiar a implementação de programas de rotulagem ambiental baseados nos países desenvolvidos deve buscar, nesse processo, garantir que as peculiaridades e características ambientais locais sejam consideradas e que os parâmetros e requisitos exigidos sejam adaptados à nossa realidade.

Outra importante iniciativa governamental foi a recente medida do governo federal, que tenta usar seu poder de compra para estabelecer critérios de sustentabilidade ambiental nas suas aquisições.

Um exemplo de selo que promove um comportamento favorável ao meio ambiente e que conta com o apoio governamental no país é o selo Procel de conservação de energia, coordenado pelo Ministério de Minas e Energia (MME).

O selo Procel de conservação de energia, instituído em 1993, é um produto do Programa Nacional de Conservação de Energia Elétrica, coordenado pelo Ministério de Minas e Energia, com sua secretaria-executiva mantida pelas Centrais Elétricas Brasileiras S/A (Eletrobras). O processo conta com a parceria do Inmetro na avaliação dos produtos.

O Procel pode ser considerado bem-sucedido por abranger uma variedade de produtos do mesmo gênero. Assim, o consumidor tem condições de comparar e decidir, fazendo uma análise entre o custo do produto e seu custo em consumo energético. Busca orientar o consumidor no ato da compra, indicando os produtos que apresentam os melhores níveis de eficiência energética dentro de cada categoria, proporcionando assim economia na sua conta de energia elétrica (IPEA, 2011).

A adesão das empresas é voluntária, mas tem sido crescente, visto que o consumidor brasileiro já busca habitualmente esta informação nos produtos, especialmente em itens de maior consumo. Atualmente existem 22 categorias de produtos, tais como refrigeradores, lâmpadas, aparelhos de ar-condicionado e sistemas de aquecimento solar.

Estima-se que foram poupados 28,5 bilhões de $\mathrm{kW} / \mathrm{h}$, por meio da mudança de hábitos de consumo de energia e água e da implantação de ações de eficiência energética. 
Esta energia economizada é suficiente para atender ao consumo de 16 milhões de residências durante um ano inteiro. Considera-se que o selo vem contribuindo também para o desenvolvimento tecnológico de produtos mais eficientes, tanto do ponto de vista tecnológico como ambiental (ELETROBRAS, 2010).

\subsubsection{A certificação florestal no Brasil}

Um setor particularmente importante para o Brasil é o da certificação florestal. Com uma área florestal de cerca de 544 milhões de ha, o Brasil é um dos países mais importantes no mundo em termos de floresta tropical. Além disso, o país é o maior consumidor de madeira tropical no mundo.

A contribuição das exportações brasileiras para o total das exportações de produtos madeireiros no mundo fica em torno de $3 \%$. Considera-se que um dos motivos da baixa participação do mercado madeireiro brasileiro no mercado internacional é a barreira imposta pela certificação florestal, que vem sendo exigida por muitos países importadores e buscada por muitas empresas brasileiras, a fim de não perderem a competitividade nos mercados emergentes (SPATHELF et al, 2004).

A certificação florestal é um processo voluntário, no qual a organização busca, por meio de avaliação por terceiros, garantir que seu produto tem origem em florestas manejadas adequadamente quanto aos aspectos ambiental, social e econômico. Existem dois tipos de certificação: a de manejo florestal propriamente dita e a da chamada cadeia de custódia, que se aplica aos produtores que processam a matéria-prima.

O processo de certificação, em geral, requer um monitoramento periódico e uma renovação a cada cinco anos. Os custos consistem nos gastos para a auditoria e para a adequação aos padrões do sistema da organização de certificação. Estima-se que a área total de florestas no mundo é de 3.952 milhões ha, sendo que apenas 8\% (294 milhões ha) encontram-se certificada (CERFLOR, 2009)

Existem, atualmente, duas grandes certificadoras florestais reconhecidas internacionalmente e atuantes no Brasil: a Forest Stewardship Council (FSC), que no Brasil se tornou o Conselho Brasileiro de Manejo Florestal, fundado em 1993, hoje sediado no México e o Programme for the Endorsement of Forest Certification Schemes (PEFC), fundado em 1998 e representado no Brasil pelo Programa Brasileiro de Certificação Florestal (CERFLOR).

O PEFC é atualmente o selo florestal mais aceito e com a maior área certificada no mundo, contando com cerca de 221 milhões de hectares. Menos de 0,5\% desta área está no Brasil. O PEFC funciona como um conjunto de sistemas de certificação de diferentes países. 
O programa não estabelece um procedimento único para certificação, mas busca fornecer uma estrutura para o desenvolvimento do reconhecimento mútuo de esquemas nacionais e subnacionais de certificação florestal locais, de acordo com requisitos comuns, internacionalmente aceitos, de manejo sustentável de florestas. Além de certificar o manejo da floresta, o sistema PEFC possui a chamada certificação da cadeia de custódia, que garante a identidade do produto florestal em toda etapa do processamento.

O PEFC geralmente atua nos países com apoio governamental. O Brasil participa do PEFC por meio do sistema Cerflor, apoiado pelo Inmetro. O Cerflor filiou-se ao PEFC em 2002 e obteve o reconhecimento internacional em 200522 (CERFLOR, 2009).

O FSC possui uma área menor certificada - aproximadamente 127 milhões de ha no mundo - mas está disseminado em um número maior de países - está presente em 79 países, enquanto o PEFC atua em 37 países. O Brasil possui, hoje, a quinta maior área de florestas certificadas pelo FSC no mundo, com 4,7 milhões de hectares. As florestas podem ser naturais ou plantadas, públicas ou privadas.

O FSC é não governamental e conta com o apoio de organizações não governamentais (ONGs) internacionais - WWF e Greenpeace - e possui em seu conselho deliberativo no Brasil algumas ONGs brasileiras e empresas de papel e celulose.

Uma questão-chave que se levanta é se a certificação representa um instrumento efetivo para diminuir a pressão e os efeitos negativos da exploração ilegal de madeira em florestas naturais. Observa-se no Brasil, como em outras partes do mundo, a dificuldade de se inserir pequenos proprietários no processo de certificação.

Além disto, em muitos casos, as florestas nativas vêm sendo substituídas pelas chamadas "florestas plantadas" certificadas. Neste sentido, o Movimento Mundial pela Proteção das Florestas Tropicais realizou uma crítica contundente aos procedimentos do FSC por considerar que este vem promovendo a plantação de grandes monoculturas de espécies exóticas por empresas industriais, principalmente de eucalipto que não podem ser consideradas "florestas", no mesmo sentido de uma floresta nativa, com sua biodiversidade intrínseca (MMFT, 2003).

De fato, observa-se no Brasil, como em outras partes do mundo, a dificuldade de se inserir pequenos proprietários e o manejo comunitário e $\mathrm{m}$ florestas nativas no processo de certificação florestal.

\subsection{Limitações no uso de programas de rotulagem ambiental}

O mecanismo de rotulagem ambiental, embora venha ganhando espaço e se multiplicando rapidamente em diversos selos pelo mundo, não é isento de críticas. De acordo com IPEA (2011), estudos realizados têm mostrado que muitos programas de 
rotulagem não vêm obtendo êxito devido a limitações e efeitos adversos em seu desenvolvimento, tais como:

1. Dificuldade de estabelecer critérios objetivos e cientificamente aceitos que identifiquem produtos "ambientalmente amigáveis" em uma dada categoria.

A falta de padrões ou definições claras de critérios ambientais dificulta a adoção da rotulagem ambiental por parte das empresas. Muitas vezes se considera apenas um atributo do produto para considerá-lo "verde". Por exemplo, o papel pode ser certificado com o rótulo (FSC) por ter origem em uma floresta plantada sustentavelmente, ignorando-se a utilização de cloro no branqueamento ou a emissão de gases de efeito estufa.

A declaração pode ser verdadeira no atributo ressaltado, mas pode não informar de forma adequada o consumidor do maior impacto ambiental negativo da categoria como um todo. Cigarros orgânicos, que continuam causando grandes malefícios à saúde, pode ser outro exemplo neste sentido, assim como veículos divulgados como eficientes no consumo de combustível, mas que acabam por estimular o transporte individual, muito mais impactante do que o coletivo.

Atualmente, há uma proliferação de esquemas de rotulagem baseados em diferentes critérios e exigências. A questão é complexa, já que reduzir o impacto ambiental em uma categoria pode significar aumentar o impacto em outra. O papel reciclado, por exemplo, pode implicar em mais efluentes tóxicos na água, oriundos da tinta. Um produto pode ter um baixo consumo de energia, mas uma emissão de resíduos sólidos relativamente grandes; outro pode gerar poucos resíduos sólidos, mas causar uma maior poluição da água em seu processo de fabricação. Estes produtos podem receber diferentes rótulos ambientais, baseados, cada qual, em um atributo específico. Por qual destes produtos o consumidor deveria optar?

Por outro lado, a avaliação integrada da totalidade dos variados aspectos de um produto em relação ao meio ambiente (Avaliação do Ciclo de Vida) é complexa, precisa de extensos bancos de dados e monitoramento e, mesmo assim, pode incluir aspectos subjetivos e conflitantes ao se comparar os produtos.

2. Os selos verdes levam os consumidores a procurar símbolos e não os informam a respeito dos aspectos ambientais específicos dos produtos que compram.

A consciência sobre o significado da rotulagem ambiental ainda é baixa entre consumidores e mesmo revendedores, particularmente em países em desenvolvimento, que carecem de campanhas educativas neste sentido. 
Os programas não encorajam os consumidores a se informarem a respeito das características dos produtos, sobre a complexidade das questões ambientais e tampouco a respeito do que podem fazer, como indivíduos, para melhorar seus hábitos de uso e disposição final dos produtos.

O consumidor comum muitas vezes não tem tempo ou conhecimento suficiente para julgar um produto por meio de um selo, desta forma, muitas vezes não compreendem as informações ambientais divulgadas pelos rótulos devido à sua complexidade ou falta de clareza, o que pode levar à relutância em adquirir o produto.

Em pesquisa feita sobre a rotulagem de produtos com ingredientes geneticamente modificados (GM) nos Estados Unidos, verificou-se a baixa resposta, em termos de maior interesse por produtos rotulados como "livres de organismos geneticamente modificados".

Para Heslop (2006), a razão disto foi a constatação de baixos níveis de conhecimento e, consequentemente, preocupação por estas questões. Concluiu-se que, sem uma campanha de esclarecimento sobre os potenciais riscos de alimentos GM, um programa de rotulagem neste sentido seria prematuro ou inócuo, pois os consumidores tenderiam a ficar indiferentes à rotulagem devido à dificuldade de fazer uma escolha consciente.

3. Os selos verdes criam barreiras comerciais no comércio internacional.

A rotulagem pode servir como medida protecionista criando barreiras comerciais, principalmente no comércio internacional. A formulação dos critérios pode se dar de forma arbitrária, realçando preferencialmente parâmetros ambientais alcançados com maior facilidade pelos produtos domésticos da parte interessada em propor o rótulo ambiental.

Em consequência, estes critérios não refletem a diversidade global das questões e práticas ambientais e tendem a estimular a discriminação contra produtos de fora do país ou da região, beneficiando estritamente consumidores do local no qual foi desenvolvido o programa de rotulagem.

Os requisitos quanto aos métodos de produção desconsideram as diferenças inerentes a cada país, por exemplo, peculiaridades climáticas, níveis de poluição existentes, matriz energética - e podem ser tão estritos ao ponto de somente o país formulador ter a possibilidade de obter o selo, por exigir uma tecnologia ou um processo específico, excluindo, principalmente, as empresas de países em desenvolvimento que carecem destas tecnologias.

Para Dias (2008), as pequenas e micro empresas são as que têm mais dificuldades em se adaptar a novas tecnologias. A discriminação em relação aos métodos de produção de outros países não pode ser considerada razoável, pois a utilização de um recurso natural 
em um determinado país pode ser muito prejudicial, enquanto em outro, não apresenta um grande impacto.

A Avaliação do Ciclo de Vida, regulamentada pela ISO 14025, já vem sendo exigida por muitos importadores, sendo que antes, se fosse pedido o estudo de ACV, a Organização Mundial do Comércio (OMC) proibiria esta exigência, por considerar a ação como barreira técnica.

Como exemplo de barreiras e dificuldades de exportação decorrentes dos programas de rotulagem, Wells (2006) menciona que os exportadores brasileiros, norte-americanos e canadenses de celulose e têxteis, por exemplo, enfrentaram grandes dificuldades, na década de 1990, para participar de processos de consulta e saber como os concorrentes europeus obtinham selos.

Outro exemplo mencionado pelo autor é o de uma grande exportadora brasileira que, em 2002, ajustou todo o seu processo fabril para se adequar a um dos principais selos europeus. Quando comunicou que estava pronta, o programa informou que havia criado mais uma exigência para o selo, a qual a empresa demoraria anos para cumprir.

Para evitar este problema, três pontos críticos devem ser observados para que um programa de rotulagem não se constitua em barreira ao livre comércio (BRASIL, 2002):

i) Acessibilidade - o acesso de empresas nacionais ou estrangeiras para obter o rótulo deve ser igual, sem obstáculos à candidatura de produtos estrangeiros;

ii) Transparência - a possibilidade de envolvimento dos participantes em todas as etapas do processo - desde escolha de critérios até a gestão do programa - deve estar aberta à participação nacional e estrangeira, com igualdade de tratamento; e

iii) Considerações sobre as especificidades do ciclo de vida do produto em cada região - como visto, é neste item que se devem tomar as maiores precauções, evitando-se que os critérios acabem por privilegiar a tecnologia adotada em um país em particular, em detrimento de outros.

4. Os consumidores não conseguem distinguir a autorrotulagem do uso de rótulos certificados por terceiros.

Como visto, na rotulagem é possível o uso de selos e rótulos não certificados por terceiros - a chamada autorrotulagem, ou autocertificação. Os consumidores não têm clareza para distinguir aqueles produtos que passaram por critérios e testes para receber um selo certificado e aqueles que afirmam, por conta dos próprios produtores ou fabricantes, estar contribuindo de alguma forma para o meio ambiente. 
Muitas vezes, as autodeclarações são utilizadas como forma de marketing ambiental por empresas, sem que se explicitem possíveis vantagens ambientais do produto frente aos similares. Alguns produtos contêm declarações que podem até ser verdadeiras, mas são irrelevantes, ou seja, não são úteis para os consumidores tomarem sua decisão na busca de produtos ambientalmente preferíveis.

"Livre de CFC" é um exemplo comum, já que é um apelo frequente apesar do fato de que os CFCs já estão banidos por lei. Outros símbolos utilizados já são obrigatórios, tais como os informativos quanto ao uso e descarte, que chamam atenção, por exemplo, para a necessidade de se direcionar a embalagem pós-consumo para o destino adequado, a lata do lixo.

O uso do símbolo de reciclagem (anel de Mobius) é outro exemplo de autodeclaração ou autorrotulagem recorrente. Usado de forma ampla em muitos produtos, esses símbolos não indicam com clareza se o material usado foi feito a partir de material reciclado ou se pode ser reciclado.

No entanto, a norma ISO 14021 estabelece que para a empresa dizer que o produto é reciclável, ela precisa comprovar que ele está sendo efetivamente coletado e reciclado em uma escala razoável. Não basta dizer que o produto poderia ser reciclado se utilizada a tecnologia apropriada ou que está sendo coletado em outros mercados no exterior.

Na União Européia, há uma preferência por programas de rotulagem ambiental tipo I, atestados por terceiros, pois se considera que os rótulos devem ser verificados de forma independente e utilizar padrões pré-estabelecidos de referência. Já em países como os Estados Unidos, há uma boa aceitação por parte da população das autodeclarações (selos tipo II), já que existe um grande controle e punição por parte do governo americano em relação a declarações enganosas. Considera-se que há maior transparência neste processo, pois o consumidor pode confrontar diretamente o fabricante para verificar a veracidade da alegação.

Para Wells (2006), no caso de um selo verde, essa contestação é mais difícil, pois se entra na discussão de quem definiu os critérios. Os que defendem as autodeclarações também argumentam que ela não cria barreiras comerciais no mercado internacional e é uma forma mais clara de comunicar, já que o símbolo ou mensagem utilizado diz exatamente do que se trata, por exemplo, papel reciclado. Já um selo de um programa de rotulagem atesta que o produto é ambientalmente superior, mas o consumidor não fica informado de quais aspectos estão sendo considerados.

Outro fator a ser considerado, é que a simples ausência de rótulos ambientais nos produtos não permite distinguir aqueles que foram submetidos a programas de rotulagem, mas falharam em atingir os critérios estabelecidos, daqueles que não foram submetidos a um programa de rotulagem, mas podem ser ambientalmente adequados. 
5. Preço mais alto dos produtos.

O esforço para adaptar o processo produtivo aos critérios e padrões estabelecidos para a certificação ou rotulagem geralmente redunda em aumento de custo para as empresas. Além disso, existe um custo para a obtenção e manutenção dos selos em programas reconhecidos, tais como taxa de inscrição, taxas anuais, custos de testes, vistorias e auditorias, pois os programas envolvem inspeções no local das instalações, sendo este custo assumido pela empresa candidata.

Tudo isto tende a se refletir, consequentemente, no preço dos produtos. Desta forma, o número de consumidores que podem ou desejam pagar por produtos verdes tende a ser reduzido em relação ao mercado de produtos tradicionais (DIAS, 2008; BLEDA; VALENTE, 2009). 


\section{Capítulo 4 ESTUdO DE CASO SOBRE O PROCESSO DE OBTENÇÃO DO FLOWER PELA FÁBRICA DE LUIZ ANTONIO NO BRASIL.}

\subsection{Introdução}

A rotulagem ambiental voluntária e a adoção de normas ambientais para a promoção da sustentabilidade facilitam a seleção de produtos e de serviços de acordo com critérios ambientais e sociais específicos, com o foco na melhoria do desempenho global dos produtos ao longo do ciclo de vida. Estas ferramentas têm se tornado uma realidade no mercado em resposta ao desejo dos consumidores de proteger um meio ambiente cada vez mais complexo.

Tais ferramentas conhecidas como instrumentos de informação ao consumidor comunicam informações sobre impactos ambientais de produtos e usam os valores sociais e ambientais dos consumidores para que os produtores possam melhorar o desempenho ambiental de seus processos de fabricação.

Além disso, levando-se em consideração as interconexões globais entre as cadeias econômicas e de abastecimento, os instrumentos de informação tem o potencial de requalificação ambiental de toda a cadeia de valor de um produto. Considerando-se todo o ciclo de vida dos produtos, podem iniciar um processo por meio do qual as empresas da cadeia produtiva possam inovar e assim, adquirir e manter uma vantagem existente em relação ao desempenho ambiental.

Do ponto de vista político, os instrumentos de informação ao consumidor, como a rotulagem ambiental, são baseados nos princípios da governança moderna, como a transparência, a participação e a responsabilidade compartilhada entre o governo, o setor privado e a sociedade civil no sentido de contribuir para o alcance dos objetivos da política da sustentabilidade.

Os déficits de implementação das políticas de comando e controle das décadas de 1970 e 1980 criaram a necessidade de um novo tipo de ferramentas políticas e de um paradigma de abordagens políticas sistemáticas e integradas, conforme descrito na Agenda 21 que foi um programa pioneiro de ação internacional sobre questões ambientais e desenvolvimentistas, voltado para cooperação internacional e ao desenvolvimento de políticas para o século XXI.

Nesta conjuntura significativa, houve o reconhecimento de que grandes problemas ambientais, como as alterações climáticas e a perda da biodiversidade, foram ocasionados pela adoção de padrões de produção e de consumo, insustentáveis. A agenda 21 priorizou a identificação de formas de cooperação entre as nações para lidar com problemas ambientais globais como poluição, mudança climática, destruição da camada de ozônio, uso 
e gestão dos recursos marinhos e de água doce, desmatamento, desertificação e degradação do solo, resíduos perigosos, e a perda da diversidade biológica.

Dez anos depois, em 2002, foi convocada pela ONU, a Cúpula Mundial sobre Desenvolvimento Sustentável (Rio + 10), em Johanesburgo, na África do Sul, com o objetivo de promover uma revisão decenal do progresso alcançado na aplicação dos resultados da Conferência do Rio de Janeiro, em 1992. O consenso político obtido dez anos antes em torno do conceito de desenvolvimento sustentável parecia haver criado uma sólida base para a colocação em prática das recomendações da Agenda 21.

Foi aprovado então, o Plano de Implementação de Johanesburgo, que propôs a elaboração de um conjunto de programas, com duração de dez anos (10 Years Framework Program), para apoiar e fortalecer iniciativas regionais e nacionais com o objetivo de promover mudanças nos padrões de consumo e de produção desses países.

No capítulo III do Plano de Implementação de Johanesburgo, denominado: "Alteração dos padrões insustentáveis de produção e de consumo", estava previsto que para conquistar o desenvolvimento sustentável em nível mundial era indispensável introduzir mudanças fundamentais nos padrões de consumo e de produção das sociedades.

Todos os países deveriam se esforçar para promover padrões sustentáveis de consumo e de produção, começando pelos países desenvolvidos e com todos os países se beneficiando deste processo, levando em consideração os princípios da Conferência do Rio, incluindo, entre outros, o princípio de responsabilidades comuns, porém diferenciadas, como definido no princípio nำ7 da Declaração do Rio sobre Meio Ambiente e Desenvolvimento.

De acordo com a Declaração, os governos, as organizações internacionais competentes, o setor privado e todos os grupos principais deveriam desempenhar um papel fundamental na mudança dos padrões insustentáveis de consumo e de produção. Isso incluiu a adoção de medidas como incentivar e promover o desenvolvimento de programasquadros decenais que apoiassem as iniciativas regionais e nacionais para acelerar 0 processo de mudança para o consumo e produção sustentáveis.

O objetivo era fomentar o desenvolvimento econômico e social dentro da capacidade de sustentação dos ecossistemas, administrando e, desvinculando o crescimento econômico e a degradação do meio ambiente, por meio da melhoria da eficiência e da sustentabilidade do uso de recursos e processos de produção, e por meio da redução da degradação, contaminação e desperdício dos recursos.

Todos os países deveriam tomar medidas com relação a esse tema, começando pelos países desenvolvidos, levando em conta as necessidades de desenvolvimento e as capacidades dos países em desenvolvimento por meio da mobilização, de todas as fontes, da assistência técnica e financeira, e da capacitação para os países em desenvolvimento. 
Para tanto, foram requeridas medidas em todos os níveis para aumentar a responsabilidade e prestação de contas (accountability) empresariais, ambientais e sociais incentivando a indústria a buscar um melhor desempenho social e ambiental, mediante iniciativas voluntárias.

Tais medidas deveriam incluir sistemas de gerenciamento ambiental, códigos de conduta, certificação e apresentação de relatórios públicos sobre questões ambientais e sociais, levando em conta iniciativas como a (ISO) e as diretrizes da Iniciativa Mundial para a Apresentação de Informações (Global Reporting Iniciative).

Nesse contexto, foi criado o Processo de Marrakesh, assim chamado por ser resultado de importante reunião na cidade do Marrocos, em 2003, como resposta à demanda dos programas propostos em Joanesburgo.

O referido Processo foi concebido para dar aplicabilidade e expressão concreta aos conceitos de Produção e de Consumo Sustentáveis (PCS) e solicitou que cada país membro das Nações Unidas, e participantes do processo, desenvolvesse seu plano de ação, para que fosse compartilhado com os demais países, em nível regional e mundial, gerando subsídios para a construção do "Global Framework for Action on SCP" (Marco Global para Ação em PCS).

\subsection{Do Projeto de Cooperação entre o MDIC/SECEX, a União Européia e o PNUMA.}

O Projeto de cooperação entre o Ministério do Desenvolvimento, Indústria e Comércio Exterior (MDIC), União Européia (UE) e o Programa das Nações Unidas para o Meio Ambiente (PNUMA), denominado "Enabling Developing countries to seize eco-label opportunities - Capacity building and technical assistance for industries and governments in developing economies" foi uma iniciativa da Comissão Européia e do PNUMA no âmbito do Processo de Marrakesh para apoiar a implementação de políticas e de projetos sobre a produção e o consumo sustentáveis em níveis regionais e nacionais.

Foi concebido para cumprir várias necessidades percebidas como:

- Melhorar o acesso aos mercados regionais, europeu e mundial de produtos rotulados de economias em desenvolvimento;

- Promover o apoio mútuo entre comércio e meio ambiente, especialmente em economias que apresentam rápido crescimento como a África do Sul, o Brasil, a China, a Índia, o México e o Quênia. Estes países desempenham um papel importante nas suas respectivas regiões e têm fortes ligações 
comerciais com a União Européia, além de já terem enfrentado problemas ambientais associados com padrões de produção e de consumo crescentes;

- Aumentar a competitividade internacional de produtos de manufatura desses países, por meio da rotulagem ambiental tipo I e;

- Aumentar a confiabilidade do rótulo ecológico como instrumento de marketing

O projeto teve como objetivo permitir que os países em desenvolvimento aproveitassem as oportunidades oferecidas pela adoção da rotulagem ambiental por meio da conscientização, da capacitação das partes interessadas como a indústria e o governo e da assistência técnica para as empresas participantes e dispostas a obterem um rótulo ambiental Tipo I.

O projeto iniciou suas atividades em fevereiro de 2007 e foi planejado para ser concluído em 54 meses. Houve duas extensões e o Projeto foi implementado em 62 meses, em 31 de março de 2011. O financiamento total foi de 1,9 milhão de euros distribuídos da seguinte forma: $90 \%$ do total foi financiado pelas instituições da União Européia e $10 \%$ pelo Programa das Nações Unidas para o Meio Ambiente (PNUMA).

De acordo com a UNEP (2006), principalmente, as pequenas e médias empresas de países em desenvolvimento e exportadores, precisam de informação ampla e efetiva sobre normas e requisitos técnicos existentes nos países importadores desenvolvidos, nos quais os programas de rotulagem ambiental operam. Esses programas exigem especialização técnica e assistência financeira para que as empresas de países em desenvolvimento possam cumprir com os critérios que contribuem para alterar as práticas de produção para níveis considerados sustentáveis.

Os governos desses países precisam compreender que as políticas e os instrumentos que apoiam a rotulagem ambiental devem criar um quadro político e dinâmico para avançar nas práticas de produção e de consumo sustentáveis

Foi elaborado então, o referido projeto que capacitou agentes do governo e do setor privado de países em desenvolvimento a adotarem a rotulagem ambiental, para, com isso, aumentarem a competitividade de seus produtos e atenderem às exigências ambientais dos principais mercados mundiais, notadamente, o mercado europeu.

A idéia básica foi promover o treinamento, a capacitação e fornecer assistência técnica para que, em cada país em desenvolvimento selecionado, pelo menos uma empresa tivesse um produto rotulado pelo Programa de Rotulagem Ambiental da União Européia (Flower), ou outro Programa de Rotulagem Ambiental Europeu, ou até mesmo um Programa Nacional de Rotulagem Ambiental, caso o país participante do Projeto tivesse um Programa de Rotulagem Ambiental ativo. 
O Projeto visou também incentivar uma ampla e melhor cooperação entre programas existentes de rotulagem ambiental. De acordo com a UNEP, isso deveria contribuir para aumentar a eficiência dos rótulos ambientais como instrumentos de marketing e apoiar os esforços para a simplificação do universo da rotulagem ambiental que poderia beneficiar os produtores e os consumidores envolvidos no processo.

Com o objetivo de alcançar essa meta específica, a UNEP desenvolveu o Projeto contando com a colaboração do Global Ecolabelling Network (GEN), que é o fórum global de discussão para os programas de rotulagem ambiental de diferentes países.

$\mathrm{Na}$ tabela abaixo estão os países participantes do projeto, seus respectivos produtos escolhidos e os coordenadores nacionais:

Quadro 4.1 Países participantes, produtos escolhidos e coordenadores nacionais.

\begin{tabular}{|l|l|c|}
\hline \multicolumn{1}{|c|}{ País } & \multicolumn{1}{c|}{ Produto } & Coordenador Nacional \\
\hline África do Sul & Produtos Têxteis & CSIR \\
\hline Brasil & Papel para cópia e impressão & MDIC/SECEX \\
\hline China & Monitores de computadores & EDC \\
\hline Índia & Produtos Têxteis & CUTS \\
\hline México & Calçados & INMC \\
\hline Quênia & Calçados & KNCPC \\
\hline
\end{tabular}

Fonte: Elaboração própria, 2015

Em nível nacional, o projeto foi coordenado pelo Ministério do Desenvolvimento, Indústria e Comércio Exterior (MDIC), por meio da Secretaria de Comércio Exterior (SECEX), que assinou termo de compromisso em 2007 com os coordenadores internacionais do projeto. O Secretário de Comércio Exterior foi o representante titular do MDIC no Projeto, enquanto que o autor desse trabalho foi o representante alterno, mas que por delegação, coordenou efetivamente as atividades exigidas pelo Projeto.

A participação nesse Projeto mostrou-se uma oportunidade importante de contribuição do MDIC para a conscientização de outros setores do governo brasileiro e do setor privado sobre a necessidade e a urgência de desenvolver novos processos produtivos e incentivar mudanças dos padrões de consumo para beneficiar a preservação dos recursos naturais.

O principal papel do MDIC no projeto de cooperação foi realizar as ações necessárias para viabilizar o envolvimento do setor produtivo nessa iniciativa e de outros representantes governamentais, promovendo ampla divulgação e conscientização da sua relevância em termos das tendências do comércio internacional. Sua atuação não se deu de forma isolada, uma vez que as oportunidades identificadas no cenário internacional têm 
contrapartida nos programas de promoção da produção do mercado interno, o que envolve necessariamente outros órgãos do governo federal.

Para participar do referido Projeto, representantes do MDIC, de outros ministérios e da coordenação internacional, escolheram o setor de papel e celulose do Brasil e o produto específico papel para cópia e impressão, levando-se em conta os requisitos exigidos para participação no Projeto de Cooperação e definidos pelos organizadores internacionais e principalmente aspectos técnicos relacionados com a cadeia produtiva envolvida, como o ciclo de vida do produto.

Além disso, foi considerada também a relevância do setor na pauta de exportações para o mercado europeu, e os entraves específicos de natureza ambiental do processo produtivo do papel para cópia e impressão que necessitavam de esclarecimentos adicionais para atender demandas tanto dos mercados internacionais quanto do mercado doméstico.

Com o apoio da Associação Brasileira de Celulose e Papel - BRACELPA e da Associação Brasileira Técnica de Celulose e Papel - ABTCP, ambas na condição de observadoras no processo, foram definidos e convidados dois grupos empresariais do setor para participar do Projeto: o grupo International Paper do Brasil e o grupo Suzano Papel e Celulose, e na ocasião, os dois únicos grupos que possuíam empresas que exportavam o referido produto para a União Européia. Após um longo período de convencimento coordenado pelo MDIC/SECEX, o grupo Suzano Papel e Celulose declinou do convite.

O grupo International Paper do Brasil (IP) tornou-se então, o únicorerpresentante do País no Projeto de Cooperação e depois de intenso estudo para definir a fábrica que participaria, indicou que a fábrica localizada no Município de Luis Antônio, no interior do estado de São Paulo, submeteria o seu processo produtivo de papel para cópia e impressão aos critérios exigidos para a obtenção do rótulo ambiental da União Européia.

De acordo com representantes da IP, a fábrica de Mogi Guaçu, a outra possível representante da empresa no Projeto, era mais antiga que a fábrica de Luiz Antônio e possivelmente não preencheria em sua totalidade, os requisitos ambientais exigidos para a obtenção do rótulo ambiental europeu, mas a diretoria da empresa utilizaria a experiência da IP para melhorar o desempenho ambiental da fábrica de Mogi Guaçu.

No decorrer do desenvolvimento das atividades do Projeto, foi envolvida no processo a Associação Brasileira de Normas Técncias (ABNT) que na ocasião estava reorganizando seu Programa de Qualidade Ambiental denominado "Colibri" que havia sido criado em 1990, mas que por falta de demanda de produtores e consumidores ainda não tinha se efetivado como um programa de rotulagem ambiental nacional.

O objetivo de envolver a ABNT no Projeto, de acordo com representantes do MDIC, foi de incentivar o desenvolvimento de um rótulo ambiental brasileiro que fosse adequado à realidade brasileira e que levasse em consideração todas as especificidades nacionais para 
desempenhar papel efetivo na educação ambiental de produtores e de consumidores do Brasil e contribuir para a formulação de políticas públicas de fomento ao desenvolvimento sustentável.

Adicionalmente, levava-se em consideração a possibilidade de avançar no mecanismo de reconhecimento mútuo entre o Programa de Rotulagem Ambiental da União Européia (Flower) e o Programa de Qualidade Ambiental da ABNT (Colibri) que poderia significar ganhos efetivos de conhecimento especializado e vantagens comerciais para ambos participantes.

O projeto foi desenvolvido em três níveis:

- Internacional: objetivou alcançar o reconhecimento mútuo entre os programas de rotulagem ambiental nacionais e os programas correspondentes da União Européia;

- Nacional: objetivou capacitar os grupos selecionados quanto ao atendimento dos requisitos e procedimentos técnicos dos programas de rotulagem ambiental;

- $\quad$ Empresarial: visou prover a transferência de tecnologia, incluindo assistência para identificar mecanismos de financiamento adequados para o cumprimento das exigências do Programa de Rotulagem Ambiental da União Européia.

O produto escolhido pelo Brasil foi submetido à avaliação do comitê especializado da União Européia representado pela AFNOR Certificacion, responsável pelo Comitê francês do programa de rotulagem ambietal europeu e que efetuou a auditoria na fábrica da International Paper do Brasil, localizada no Município de Luiz Antônio, em março de 2011.

A metodologia utilizada foi a de Análise do Ciclo de Vida (ACV) que considera os impactos ambientais ao longo da vida do produto "do berço ao túmulo" desde a extração de matérias primas até a disposição final, passando pela produção, distribuição e uso. As categorias gerais de impactos ambientias consideradas incluíram o esgotamento de recursos, a sáude humana e as consequências ecológicas.

\subsection{Considerações sobre o setor de Papel e Celulose do Brasil}

O segmento de celulose e papel é ramo industrial globalizado, de capital intensivo e que requer um longo prazo de maturação de seus investimentos. Este segmento, no Brasil, é responsável por uma produção anual de 10,3 milhões de toneladas de celulose e 8,6 milhões de toneladas de papel, ocupando a $7^{\underline{a}}$ e a $11^{\text {a }}$ posições, respectivamente, entre os maiores produtores do mundo (BRACELPA, 2010).

No Brasil, a quase totalidade da produção de papel se dá a partir da celulose obtida de madeiras de áreas de reflorestamento que podem ser de eucaliptos ou de pinus, conforme as demandas de mercado. 
A maior difusão do eucalipto se deve a suas vantagens competitivas, como boa aclimatação às condições brasileiras, permitindo aproveitamento da planta em até 7 anos, além da melhora das propriedades de maciez proporcionadas aos papéis da linha sanitária. A produção de papel, papelão e outros artefatos afins podem ocorrer a partir da fibra celulósica virgem, da reconstituição da polpa de papel reciclado (aparas), ou ambas combinadas.

Uma dada unidade industrial pode apenas processar a polpa produzida por um determinado fornecedor de polpa, ou funcionar como uma unidade integrada - fábrica de papel e celulose, como é o caso da fábrica da International Paper do Brasil no município de Luiz Antônio.

Os impactos ambientais variam conforme o processo envolvido. A emissão de CO2 ocorre em três pontos principais:

- na área de produção florestas, especificamente, no corte da madeira e no picador.

- na produção de papel e celulose, especificamente na geração do lodo orgânico e o seu transporte e,

- no processo de produção do papel e armazenamento devido o uso de máquinas para transporte de resmas e bobinas de papel, conforme o Fluxo do setor de silvicultura, celulose e papel

A produção de polpa de celulose, chamado de polpeamento, varia conforme as características desejadas para o produto final e o processo empregado para remoção de lignina das fibras. Existem várias classificações possíveis para grupos homogêneos de empresas no segmento de celulose e papel e para a Associação Brasileira de Celulose e Papel (Bracelpa), que reúne as principais empresas deste segmento no Brasil, a classificação é a seguinte:

I) produtores de celulose e de pastas de alto rendimento (PAR),

II) produtores integrados (celulose + papel),

III) produtores de papéis, inclusive para fins sanitários,

IV) produtores de papel a partir da reciclagem de fibras secundárias ou papel velho.

A pasta celulósica pode ser obtida a partir de fibras recicladas, ou através de fibras virgens como as do linho, sisal, bagaço de cana ou bambu, mas é da madeira que provém a maior parte da matéria fibrosa virgem utilizada na produção das pastas. Uma combinação entre o tipo de fibra, processo, alvejamento resulta na produção de diferentes tipos de pastas e, conseqüentemente, na obtenção dos vários tipos de papel, como é o caso da pasta branqueada, que resulta em um papel com maior grau de alvura. 
Em termos de processos de obtenção das pastas, estas podem ser divididas em dois grupos: pastas químicas e semiquímicas, que originam a celulose através de processos químicos, e pastas de alto rendimento (PAR), obtidas por processos mecânicos.

Pouco mais da metade da celulose que é produzida no Brasil é consumida pelos produtores integrados. Do restante, cerca de $40 \%$ são comercializados para o mercado externo e apenas $10 \%$, segue para produtores de papel no mercado interno (BRACELPA, 2010). No tocante às PARs, $87 \%$, são aproveitados pelos próprios produtores e $13 \%$ seguem para outros produtores de papéis e embalagens.

Segundo a Bracelpa (2006), os cinco maiores fabricantes de celulose no Brasil concentravam, em 2005, 72\% da produção total desta commodity e eram representados por: Aracruz Celulose S/A, com 2,78 milhões; Votorantim Celulose e Papel S/A, com 1,34 milhões; Klabin S/A, com 1,18 milhões; Suzano Papel e Celulose, com 1,16 milhões e Celulose Nipo-Brasileira S/A (Cenibra) com 0,97 milhões de toneladas.

Os cinco maiores produtores de celulose são integrados. A Aracruz possui a maior fábrica de celulose de fibra curta à base de eucalipto do mundo e destina ao mercado externo $94 \%$ do que produz o que lhe confere uma liderança indiscutível neste mercado.

Em 1990, 56\% da produção de papel originavam-se de dez fabricantes. Passados quinze anos, esta participação atingiu, em 2005, 60\%. Em 2005 os dez maiores produtores de papéis foram a Klabin S/A (16,93\%), Suzano Papel e Celulose (9,60\%), International Paper do Brasil Ltda. (7,24\%), Votorantin Celulose e Papel S/A (7,04\%), Ripasa S/A Celulose e Papel (5,96\%), Rigesa Celulose, Papel e Embalagens Ltda. (3,62\%), Orsa Celulose, Papel e Embalagens S/A (3,21\%), Trombini Industrial S/A (2,27\%), Norske Skog Pisa Ltda. (1,98\%) e Celulose Irani S/A (1,96\%). 85\% do total da produção de papel em 2005 foram direcionados ao mercado interno (BRACELPA, 2010).

A primeira forte entrada de capitais estrangeiros na indústria de celulose e papel ocorreu na década de 1950, quando a Rigesa, uma fábrica de embalagens de Valinhos (SP), foi adquirida pela americana Westvaco Corporation (1953), e a Pan-americana Têxtil, de Mogi Guaçu (SP), foi adquirida pela Champion International Corporation (1959), também dos Estados Unidos.

O movimento de reestruturação empresarial nessa indústria, com algumas incorporações e fusões, sobretudo a partir de 2000, impulsionou o seu crescimento, tornando-o mais concentrado. Em 2005, a concentração ampliou-se com o início das operações da Veracel, empresa pertencente à Aracruz e a sueco-finlandesa Stora Enso, com $50 \%$ cada uma.

O ritmo de concentração continuou em 2005, quando da aquisição da Ripasa pela Votorantin e pelo grupo Suzano Bahia Sul, em partes iguais. 
No início de 2006, a Votorantin foi vendida para a International Paper, ficando somente com os seus negócios na área florestal. Até 2004, a participação de capital estrangeiro na produção de celulose no Brasil estava centrada no capital japonês da Cenibra, na finlandesa Norske Skog e nas americanas International Paper e Rigesa.

O capital estrangeiro, do total de 9,62 milhões de toneladas produzidas em 2004, foi responsável por uma participação de 18,2\%, ou seja, 1,75 milhão de toneladas de celulose. Em 2006, com a entrada em operação da Veracel, aquele percentual subiu para 20,6 \%, ou seja, 2,20 milhões, de um total de 10,63 milhões de toneladas de celulose. (BRACELPA, 2010).

As empresas americanas International Paper, Rigesa, Sonoco e Kimberly-Clark, a franco-americana Schweitzer-Mauduit, as finlandesas Norske Skog, Huhtamaki e Ahlstrom, e a franco-inglesa Arjo Wiggins foram responsáveis por uma produção quase 1,4 milhão de toneladas de papéis em 2004, correspondente a $16 \%$ do total da produção nacional daquele ano, de 8,452 milhões de toneladas (BRACELPA, 2006).

O volume das exportações é um excelente indicador do grau de competitividade de um segmento econômico. As exportações brasileiras de celulose cresceram $174 \%$ em volume entre 1995 e 2005, de 1,984 milhões para 5,441 milhões de toneladas, o que corresponde a uma média anual de 10,6\%.

A média anual de crescimento do comércio internacional de celulose tem sido de $4 \%$. É, portanto, cada vez maior a presença brasileira no comércio mundial de celulose. No caso dos papéis, conforme dados do Banco Nacional de Desenvolvimento Econômico e Social (BNDES, 2001), na década de 1990, a participação brasileira no comércio internacional de papéis chegou a cair de $2 \%$ em 1990 para 1\% em 1999.

Nos últimos anos, o saldo da balança comercial brasileira de celulose e papéis tornou-se positivo e com tendência de crescimento. Em 2005, o saldo comercial foi de US\$ 2,541 bilhões, $5,7 \%$ do superávit total da balança comercial brasileira no ano, de US\$ 44,735 bilhões.

As importações brasileiras de celulose não apresentaram crescimento no período entre 2000 e 2005; pelo contrário, verificou-se uma diminuição. De um patamar de 329 mil toneladas em 2000, estas importações caíram para 310 mil toneladas em 2005. Analogamente às importações de celulose, também houve uma queda nas importações de papéis entre 2000 (839 mil toneladas) e 2005 (770 mil toneladas).

Em relação às importações brasileiras de papel, observa-se a utilização de tarifas como mecanismo de proteção à indústria nacional. Conforme Coutinho et al. (2003), um dos exemplos mais marcantes é o de papéis de imprensa, no qual a produção interna não alcança a demanda, e que apresenta a menor tarifa, $9 \%$. 
No caso dos produtos cuja oferta interna atende adequadamente à demanda, as tarifas são maiores, como no caso dos papéis para imprimir e escrever, cujas tarifas são da ordem de $14 \%$. Os resultados econômicos da atividade industrial de celulose e papel demonstram crescimento constante e conseqüente aumento de consumo de energia e aumento da auto-geração.

\subsubsection{Processos de fabricação}

\subsubsection{Produção de Celulose}

Os processos produtivos têm relação direta com o tipo de fibras celulósicas que se pretende trabalhar, variando muito as formas do processamento industrial das fibras longas, fibras curtas e fibras secundárias.

A celulose é constituída por fibras vegetais que estão agrupadas na forma de fibrilas, formando as microfibrilas $\mathrm{e}$ as macrofibrilas, com dimensões que variam conforme 0 espécime vegetal analisado. A celulose de coníferas, por exemplo, apresenta um comprimento de fibra entre 3 a $5 \mathrm{~mm}$, tem grande valor de mercado e confere ao papel resistência mecânica, o que a qualifica para a fabricação de papéis de embalagem. Os processos químicos de polpeamento da celulose de fibras longas apresentam um rendimento sobre a madeira relativamente baixo, de cerca de $48 \%$.

As fibras celulósicas curtas apresentam um comprimento entre 0,8 e 1,5 mm, são mais macias e conferem opacidade ao papel; entretanto elas possuem uma menor resistência mecânica e são indicadas para papéis de impressão e escrita. O rendimento de processos químicos aplicados a fibras curtas é maior que $50 \%$.

A variedade de fibras disponíveis para a produção de papel acaba impondo determinadas soluções tecnológicas no processo produtivo. Neste contexto, é que se explicam as diferenças significativas existentes no processamento de fibras curtas e longas, que influenciam vários processos de fabricação de celulose e de PAR.

Para a produção de celulose são utilizados processos químicos e semiquímicos, enquanto que para a produção de PAR empregam-se processos de base mecânica que diferem entre si quanto ao grau de consumo de energia na etapa de polpação.

Os processos químicos utilizam soluções aquosas contendo reagentes químicos para a remoção da lignina, que é o elemento ligante das fibras da madeira, provocando a separação destas fibras. A pasta resultante contém uma grande concentração de celulose.

Os processos de base mecânica, como o próprio nome sugere, separam as fibras da madeira através da utilização intensiva de forças mecânicas. Geralmente, nestes processos, os elementos removidos são poucos e, normalmente, são finos e solúveis em água. Além de 
diferentes níveis de consumo de energia, há outro importante indicador comparativo entre os processos, que é o rendimento da madeira após a polpação.

\subsection{Processos químicos e semiquímicos para a produção de celulose e o processo Kraft}

Os processos químicos e semiquímicos caracterizam-se pela utilização de agentes químicos durante a fase de cozimento dos cavacos de madeira. O sulfito de cálcio era o agente químico mais utilizado até a década de 1950; todavia, em face do seu alto impacto ambiental, o processo que o utilizava foi substituído pelo processo sulfato.

Com a evolução tecnológica, o processo de produção que vem ganhando espaço a partir da década de 1980 é o semiquímico, que é uma variação do processo sulfito, com a utilização do sulfito neutro de sódio. Ele utiliza uma menor quantidade de produtos químicos, - que, somado a melhorias conseguidas nas etapas de polpação e refino, tem proporcionado uma diminuição na emissão de poluentes.

O processo sulfato, também conhecido como processo Kraft, conforme Figura 1, a seguir, apresenta várias vantagens sobre o processo sulfito e outros processos. Ele admite uma variada gama de matérias primas e tamanhos de fibras, possui tempos de cozimento de cavacos relativamente mais curtos e gera uma pasta mais resistente, com vários níveis de alvura, além de possibilitar a recuperação de subprodutos e dos agentes químicos utilizados.

Os produtos químicos básicos empregados são o hidróxido de sódio e o sulfeto de sódio. Por outro lado, o processo Kraft tem desvantagens, tais como a necessidade de um maior aporte de investimentos na construção da planta e um gasto extra com a operação de branqueamento, uma vez que a celulose obtida é pouco alva.

Sob a ótica energética, uma grande vantagem oferecida pelo processo Kraft é a possibilidade de recuperação de subprodutos e dos reagentes químicos. Neste contexto é que é obtido o licor negro, ou lixívia, utilizado em uma caldeira de recuperação para gerar vapor, para fins térmicos e/ou autoprodução de eletricidade.

No Brasil, $81 \%$ da polpa química é produzida pelo processo Kraft, $12 \%$ pelo processo soda e os $7 \%$ restantes por outros processos Centro de Tecnologia em Celulose e Papel (CETCEP).

$\mathrm{Na}$ produção de celulose pelo processo Kraft tem-se algumas etapas fundamentais, além do preparo da madeira, como cozimento, lavagem, depuração e espessamento, branqueamento e recuperação de produtos químicos.

O branqueamento consiste, basicamente, na remoção das substâncias que conferem cor à massa de celulose. Estas substâncias encontram-se associadas à lignina, 
representando apenas uma porção pequena em relação a ela. O branqueamento é realizado em três etapas fundamentais: a deslignificação; o tratamento cáustico e o branqueamento propriamente dito, efetuado por agentes fortemente oxidantes, como o cloro, hipocloritos, peróxidos, dióxidos de cloro, etc.

É o processo que provoca a maior preocupação ambiental, pois mais de 3.000 substâncias e produtos químicos são gerados, principalmente no branqueamento convencional, em que o agente oxidante mais comum é o cloro. Várias mudanças foram e estão sendo feitas para minimizar os efeitos ambientais e, ainda, proporcionam uma celulose com alvura aceitável. $O$ branqueamento gera efluentes líquidos em quantidades significativas.

Uma das vantagens mais significativas do Processo Kraft é que propicia a recuperação de matérias-primas empregadas no processo. O processo Kraft permite a recuperação do hidróxido de sódio do licor negro, além da geração de vapor, que pode ser empregado na produção de energia elétrica. As etapas envolvidas na recuperação de produtos químicos do licor negro são:

I) concentração do licor negro em evaporadores de múltiplo efeito. Nesta etapa, a concentração de sólidos no licor negro passa de $15 \%$ para $55 \%$;

II) queima do licor negro concentrado na caldeira de recuperação, em que os gases de combustão são usados para geração de vapor e o material fundido, constituído basicamente de carbonato de sódio e sulfeto de sódio, é dissolvido com o licor branco fraco, da recaustificação, formando o licor verde. O licor verde é clarificado, dando origem a impurezas sólidas que, após lavagem, se constituem nos resíduos sólidos chamados dregs. A caldeira de recuperação gera, ainda, material particulado e gases odoríferos, além de gases oxidados de enxofre e nitrogênio;

III) caustificação do licor verde, resultado de sua reação com cal, formando o carbonato de sódio e o hidróxido de sódio. Um clarificador separa a lama contendo carbonato de cálcio do clarificado (hidróxido de sódio). A lavagem da lama acontece com água fresca, água dos condensadores da evaporação, ou água de lavagem dos dregs e se constitui no licor branco fraco. Os sólidos aqui retidos são chamados de grits. Formam-se gases malcheirosos;

IV) a cal é adensada em filtros a vácuo e calcinada em fornos de cal, transformando-se em óxido de cálcio, que retorna ao processo. O forno de cal é uma grande fonte de emanação de material particulado e compostos reduzidos de enxofre. 
Figura 4. O Processo Kraft de fabricação de celulose e a recuperação de produtos químicos em uma planta integrada

Forno de cal

Pátio de madeira

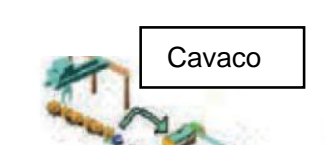

Caldeira de Biomassa
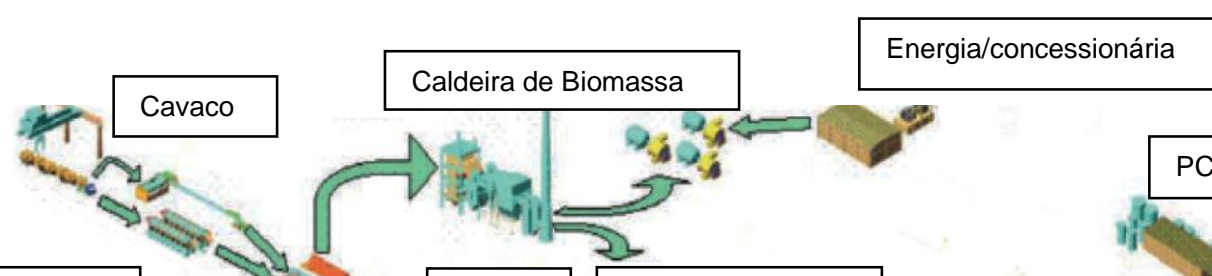

Pilha de cavaco

Vapor Planta Química

Papel

गु?

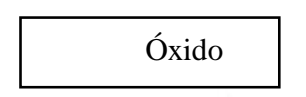

Carbonato de cálcio

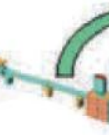

.
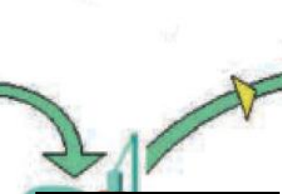

Licor-massa

Licor verde

Licor verde

Licor Preto

Secagem

Efluente

ETE

\section{Caldeira}

recuperação
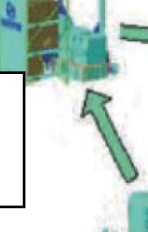

Água tratada

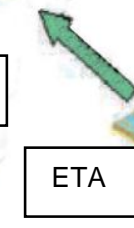

Água caldeira

ETA

ETAC

Fonte: Federação da Indústria do Estado de São Paulo- FIESP; Companhia de Tecnologia de Saneamento Ambiental- CETESB, 2008.

O consumo de lixívia para a cogeração de eletricidade é bastante alto na indústria de papel e celulose. Produzida e utilizada somente em plantas integradas e produtoras de celulose, o seu poder calorífico é relativamente baixo, de modo que grandes volumes de lixívia geram uma quantidade de energia relativamente baixa.

O crescimento do consumo deste composto químico acompanha o ritmo de produção de celulose, de modo que alterações no perfil da produção induzem alterações no consumo de lixívia.

São inúmeras as tecnologias introduzidas nas caldeiras de recuperação para a melhora de seu desempenho energético e ambiental. Pode-se mencionar os casos da lavagem e incineração dos gases do tanque de dissolução na caldeira, e o sistema multilevel de ar de combustão, que proporcionam o abatimento das emissões de óxidos de nitrogênio (NOx) e compostos reduzidos de enxofre (TRS), entre outros.

Além disso, a adoção de tecnologias que utilizam mais de quatro níveis de ar na fornalha tem proporcionado bons resultados em termos das eficiências energética e 
ambiental, resultando na conciliação de emissões de CO e NOx , com níveis abaixo de 120 ppm.

Especificamente sob a ótica energética, ganhos têm sido obtidos a partir do aumento do teor de sólidos do licor negro e aumento de área de troca térmica na caldeira, pela utilização de reaquecedores e de pré-aquecedores. O aumento do teor de sólidos da lixívia até o nível de $85 \%$ tem significado uma elevação de 3,15 para 3,5 t de vapor por tonelada de lixívia queimada - base seca, além de melhorias ambientais, visto que as emissões de enxofre são substancialmente reduzidas.

\subsubsection{Produção de papel}

Embora os diversos tipos de papéis se diferenciem segundo suas especificações físicas e químicas e formas de acabamento, sua fabricação segue as mesmas etapas básicas, resumidas a seguir. Isto também vale para a reciclagem de papéis.

A etapa inicial da fabricação de papel corresponde à preparação da massa, na qual a matéria-prima fibrosa recebida varia de acordo com o nível de integração da planta, conforme Figura 5.

As plantas fabricantes de papel adquirem a celulose de mercado enfardada e seca, enquanto que, em uma planta integrada, a celulose chega em suspensão, facilitando a produção de papel.

O preparo da massa compreende três operações distintas: desagregação; refinação e depuração. O objetivo da desagregação é dar consistência aos materiais que entram no processo e acontece em equipamento conhecido como tanque desagregador.

Na refinação, a suspensão obtida é adequada à formação da folha de papel. Esta operação é vital, pois influencia diretamente as características finais da folha de papel. Os refinadores são equipamentos grandes consumidores de eletricidade. $\mathrm{Na}$ depuração, o objetivo é retirar todas as impurezas contidas na suspensão fibrosa. Os equipamentos utilizados nesta operação são as peneiras e depuradores centrífugos.

Após esta operação, a suspensão fibrosa é depositada nas telas da máquina de papel, onde, a partir da redução de sua umidade através de processos mecânicos de drenagem e sucção, inicia-se a formação da folha de papel, e posterior prensagem. Normalmente há duas prensas por máquina de papel. A velocidade da máquina está diretamente relacionada ao tipo e qualidade do produto final desejado. 
Figura 5- Etapas básicas para a fabricação de papel

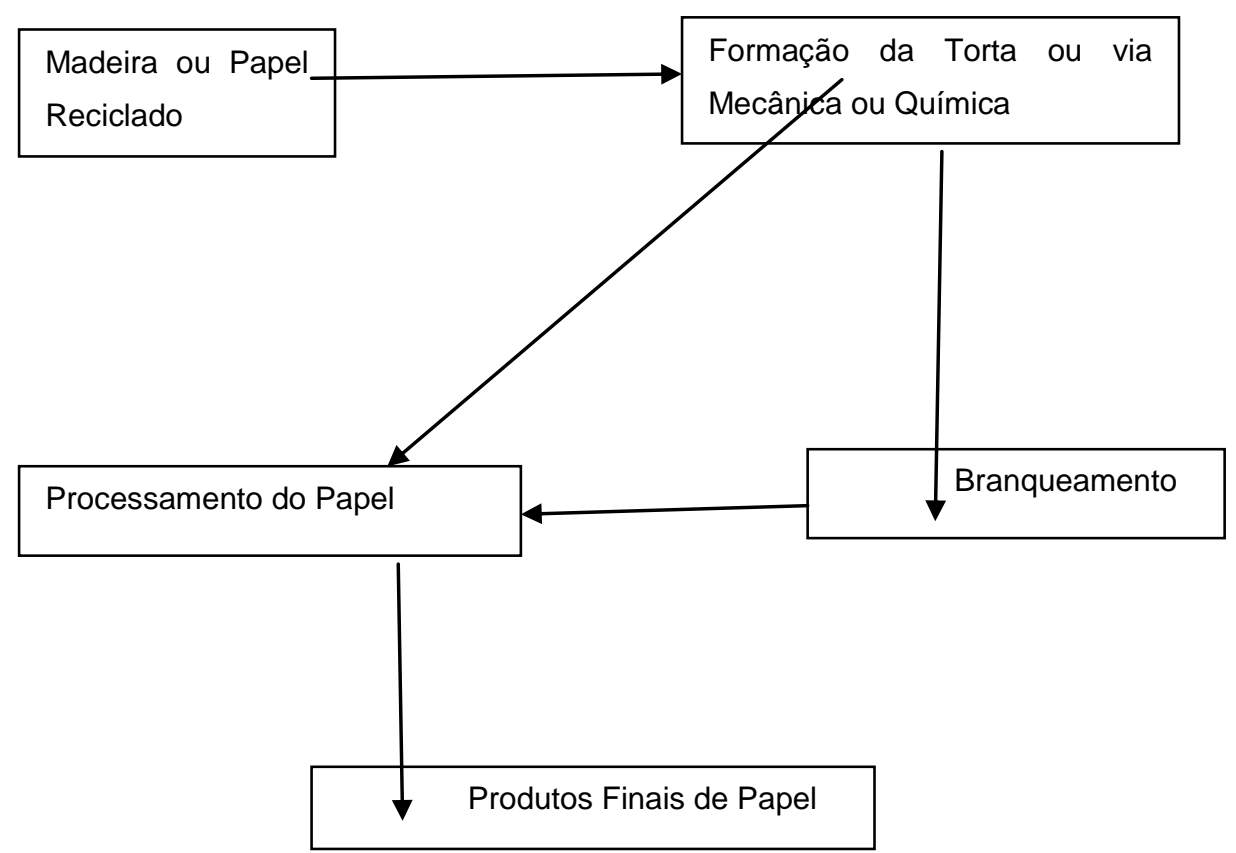

Fonte: CNI, 2010.

A folha de papel segue, então, para a seção de secagem na máquina, onde a umidade residual é retirada através de cilindros aquecidos. Nesta operação, além do consumo de eletricidade para força motriz, existe um consumo elevado de energia térmica na secagem propriamente dita. Dependendo do tipo de produto requerido, a folha de papel é encaminhada para tratamento superficial e acabamento final.

\subsubsection{O processo de reciclagem}

A atividade de reciclagem de papel é complementar à produção de matérias-primas fibrosas virgens, que constituem os principais insumos do processo de fabricação de papel. A reciclagem dos papéis é, tecnicamente, muito difícil após quatro a cinco ciclos sem a entrada constante de matérias-primas fibrosas virgens no processo.

Há algum tempo as fibras de celulose reciclada vêm se tornando um insumo indispensável à indústria, principalmente devido ao preço potencialmente mais vantajoso do papel reciclado, quando comparado ao da celulose virgem. Sem falar em sua crescente popularidade, devida às diversas campanhas pelo consumo consciente.

O processo básico de produção a partir de aparas é muito similar ao que só emprega celulose virgem; a grande diferença diz respeito à ausência das operações de digestão e à necessidade muito maior por etapas de depuração e limpeza. Existe a necessidade de préseleção das aparas a serem recicladas 
O papel reciclado é separado do lixo e vendido a sucateiros, que o enviam a depósitos. Ali, o papel é enfardado em prensas e, depois, encaminhado aos aparistas, que classificam as partidas e as revendem para as fábricas de papel como matéria-prima. $O$ transporte é feito em caminhões cobertos, para evitar a absorção de umidade.

Ao chegar às plantas, os fardos de papel são pesados e classificados. Essa classificação é feita de acordo com alguns critérios como grau de brancura, nível de contaminantes, etc. O resultado desta classificação condiciona o preço de aquisição. Após essa etapa, os fardos usualmente ficam armazenados a céu aberto, aguardando processamento. As etapas deste processamento são preparação da massa, depuração e lavagem, destintamento das aparas, branqueamento, refino ou despastilhamento, depuração fina e acerto do comprimento da fibra e formação da folha de papel.

Em seguida ocorre a formação da folha de papel, a partir da seção denominada caixa de entrada, que injeta a suspensão homogeneamente sobre a mesa ou formador. As bordas irregulares da folha formada são aparadas com jatos de água a alta pressão, antes de seguir para a seção de prensas, onde se retira mais de $50 \%$ da umidade presente na folha.

Na seção de secagem da máquina de papel, a aplicação de vapor sob pressão no interior dos cilindros de secagem leva a massa até seu teor de umidade final, de $5 \%$ a $7 \%$, formando-se a folha de papel. Após essa fase passa-se para o rebobinamento para formar bobinas menores, geralmente enroladas em tubetes de papelão, pois facilita o manuseio e transporte.

\subsection{O grupo international paper do Brasil Ltda}

A International Paper é uma compania global de papel e de embalagens que é complementada por um extenso sistema de distribuição norte-americano, com mercados primários e operações de fabricação na América do Norte, Europa, América Latina, Rússia, Ásia e Norte da África.

A empresa iniciou suas atividades em 1898 e sua sede administrativa mundial está localizada nos Estados Unidos. Tem operações em 20 países diferentes e exporta seus produtos para mais de 120 países. No Brasil, a International Paper iniciou suas atividades em 1960, no município de Mogi Guaçu, no estado de São Paulo. 
Figura 6 Vista aérea da fábrica de Luiz Antônio (SP), do grupo IP.

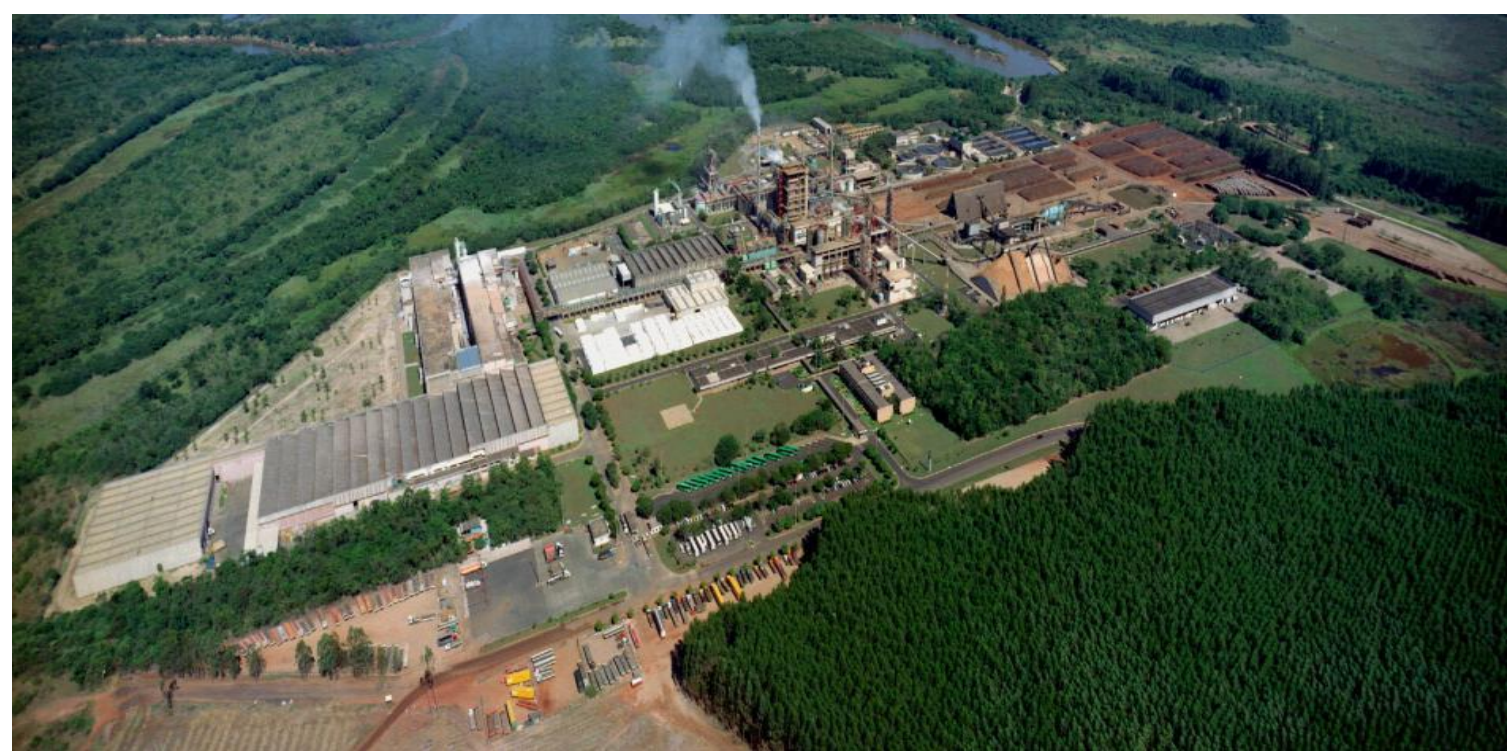

Fonte: International paper do Brasil, 2009

Atualmente a empresa desenvolve suas atividades no Brasil por meio de três fábricas sendo que duas delas são fábricas integradas de papel e celulose localizadas nos municípios de Mogi Guaçu e Luiz Antônio, ambos no estado de São Paulo, e a terceira, produtora de papel, está localizada no município de Três Lagoas, no estado de Mato Grosso do Sul (MS). A capacidade anual de produção é de mais de 1 milhão de toneladas de papel não revestido para cópia e impressão.

Com o propósito de fornecer madeira para as fábricas de papel, a International Paper do Brasil possui aproximadamente 102.000 ha de terra, sendo que 72.000 ha para reflorestamento de eucalipto e 25.000 ha para a conservação da natureza.

\subsubsection{Descrição do Processo de Produção da International Paper do Brasil Ltda}

O processo de produção da IP é em geral, o mesmo processo que é utilizado pelas outras fábricas de celulose e papel, do Brasil e do Mundo, com algumas especificidades consideradas importantes e que foram adotadas para preencher os requisitos que foram exigidos para a obtenção do Rótulo Ambierntal da União Européia. Dessa forma será descrito o processo de produção utilizado pela unidade da IP localizada no município de Luis Antônio que foi a fábrica escolhida pela International Paper do Brasil para ser submetida ao processo de obtenção do Flower.

É importante ressaltar que todo o processo de auditoria da fábrica foi acompanhado pelo autor desse trabalho, na condição de pesquisa de campo que foi realizada nos dias 15 e 16 de junho de 2011. 


\subsubsection{Processo de Produção da Celulose}

Com o objetivo de efetivamente apresentar informações sobre o processo produtivo utilizado pela IP que foram exigidas pelo Programa de Rotulagem Ambiental da União Européia, é feita uma descrição sobre os setores que compoem a fábrica de Luis Antônio, com a identificação de equipamentos e da tecnologia empregada.

O processo de preparação da madeira pode ser considerado como o ponto inicial do processo produtivo e começa com o envio das toras de eucalipto com casca para a fábrica por meio de caminhões que transportam a madeira vinda das florestas plantadas, localizadas dentro de um raio de $140 \mathrm{~km}$. Quando chega à fábrica, a descarga da madeira é feita por guindastes fixos que já conduzem a carga, por meio de uma correia transportadora até um tambor, no qual as toras de eucalipto são descascadas.

\section{Figura 7 Preparação da madeira}

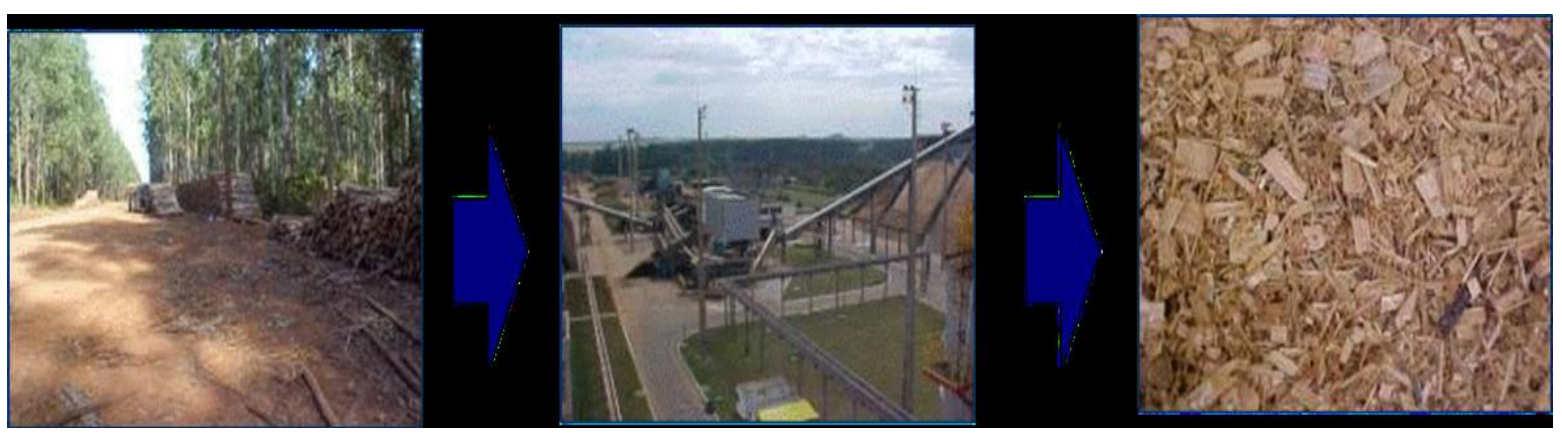

Fonte: International Paper do Brasil Ltda, 2011

Em seguida o material resultante passa por um sistema de rolos onde as cascas são separadas dos pedaços de madeira. Após a separação, as cascas são lavadas com água reciclada, a fim de remover impurezas como resíduos da casca e areia, antes de entrar no picador.

Paralelamente, outra linha é executada para preparar a madeira sem casca. Nesta linha o sistema de tratamento da madeira é essencialmente o mesmo. Os pedaços de madeira são enviados então ao picador que os tranforma em pedaços menores (cavacos). Ressalta-se que a linha de preparação da madeira descascada tem a capacidade de processamento de $10 \%$ das necessidades de produção de celulose.

A partir do picador, os cavacos passam por um processo de seleção. Aqueles que são aceitos são transportados pela correia transportadora para a pilha (estoque) de cavacos; os que foram rejeitados são transportados por outra correia transportadora até a pilha de biomassa para serem queimados. 
As cascas de madeira que escapam do processo por meio das fendas do tambor de descascamento e das mesas de rolos, assim como os resíduos de madeira e os pequenos cavacos que caíram do tambor, e os cavacos rejeitados são triturados e enviados para uma "pilha" de biomassa para serem queimados na caldeira de biomassa. Enquanto que a casca de madeira e serragem recolhidas sob as mesas das correias transportadoras são encaminhadas para o sistema de compostagem.

\section{Figura 8 Amazenagem das aparas e a disposição em pilhas}

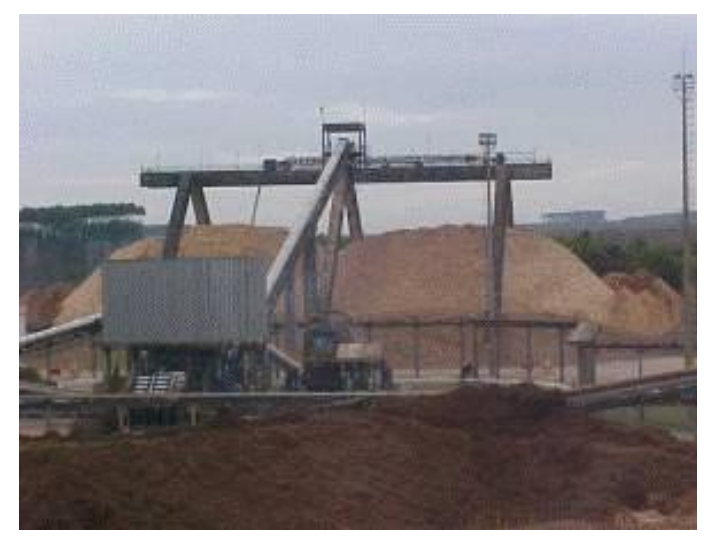

Fonte: International Paper do Brasil Ltda, 2011

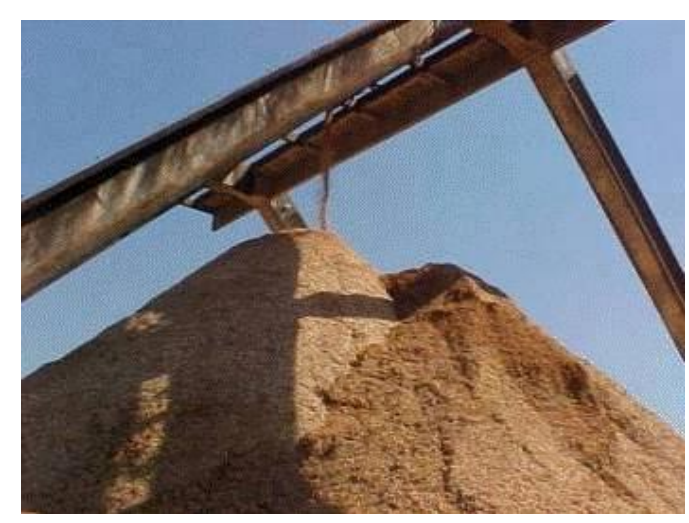

Fonte: International Paper do Brasil Ltda, 2011

O próximo passo do processo produtivo é o cozimento que é composto por um digestor contínuo Kvaerner (antigo Kamyr). O processo de cozedura começa com a transferência de cavacos do armazenamento diretamente para o digestor por meio de uma correia transportadora.

Em seguida, adiciona-se licor branco para tornar a mistura com os cavacos de madeira seca, 14-15\% alcalina. Adiciona-se também licor negro, até atingir uma relação entre os cavacos sólidos e o líquido de cozimento de 1: 3,8.

O tipo de sistema de aquecimento utilizado é o indireto e após o cozimento, a mistura formada pela pasta com o licor negro é lavada para remover o licor negro da mistura, em uma zona de lavagem. A polpa é enviada, então, para o tanque de vento.

Do tanque de vento a polpa é bombeada para o separador pressurizado de "nós", que são os cavacos mal cozidos da etapa anterior. O depurador de nós separa os nós, a partir do fluxo principal que consiste em uma mistura diluída de polpa com licor negro restante da etapa anterior. Os resíduos do separador são então, enviados para a compostagem. 
Figura 9 Digestor da fábrica de Luiz Antônio

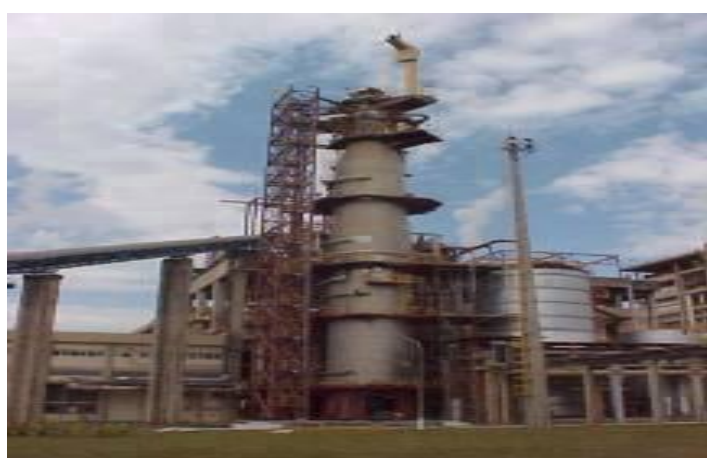

Fonte: International Paper do Brasil Ltda, 2011

Do tanque de vento a polpa é bombeada para o separador pressurizado de "nós", que são os cavacos mal cozidos da etapa anterior. O depurador de nós separa os nós, a partir do fluxo principal que consiste em uma mistura diluída de polpa com licor negro restante da etapa anterior. Os resíduos do separador são então, enviados para a compostagem.

Em seguida, no próximo passo do processo produtivo, a celulose originária da separação dos nós, é enviada para um sistema de lavagem e para a pré-deslignificação, que é um processo quuímico para a retirada da lignina. A polpa resultante desse processo ainda contém uma quantidade relativamente elevada de lignina residual que vai ser dissolvida no processo de branqueamento.

Figura 10 Procesos de remoção dos nós, lavagem, deslignificação com Oxigênio e depuração da massa.
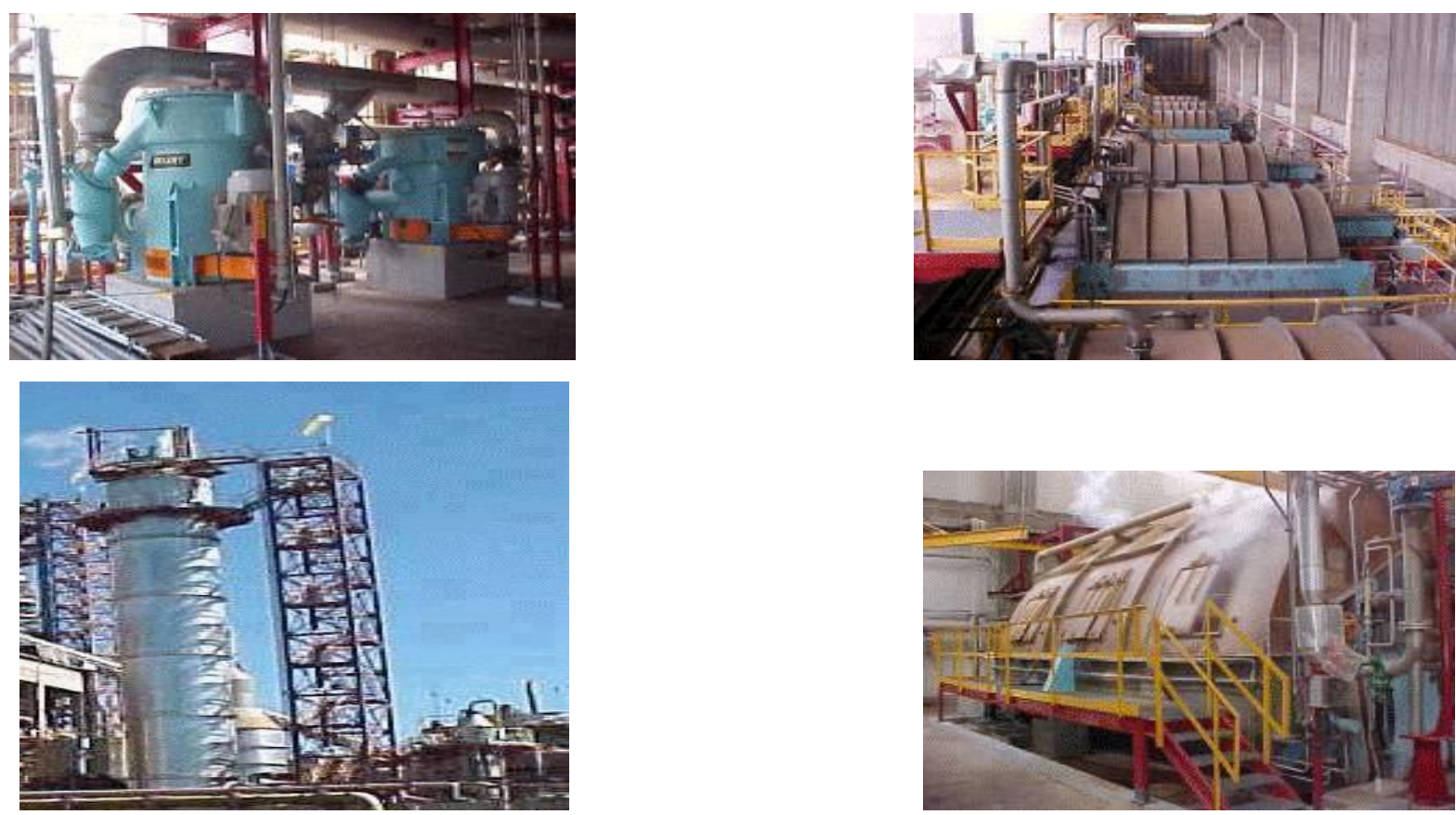

Fonte: International Paper do Brasil Ltda, 2011 
A primeira fase da pré-deslignificação, com oxigênio, reduz a massa de lignina na pasta, que é recuperada com o licor negro. O processo consiste em submeter a polpa a um tratamento com oxigênio, durante cerca de 60 minutos, a uma temperatura em torno de $100^{\circ} \mathrm{C}$ e pressão entre 4 e $4,5 \mathrm{kgf} / \mathrm{cm}^{2}$ em meio alcalino médio.

A pasta passa por um processo de oxidação com peróxido de hidrogênio pressurizado para aumentar a eficiência do pré-branqueamento. Este processo reduz drasticamente a quantidade de resíduos gerados na etapa do branqueamento e os resíduos do pré-branqueamento são enviados para a recuperação química. A massa refinada é enviada, então, para a torre de armazenamento de massa pré-branqueada.

O processo de branqueamento é a próxima etapa e tem o objetivo de retirar a lignina residual não removida nos processos de cozimento e da pré-deslignificação. Ressalta-se que desde maio de 1998, o sistema de branqueamento utilizado pela International Paper do Brasil Ltda em seu processo de produção é o "Elementary Chlorine Free (ECF)" que não utiliza o gás cloro.

\section{Figura 11 A torre de branqueamento}

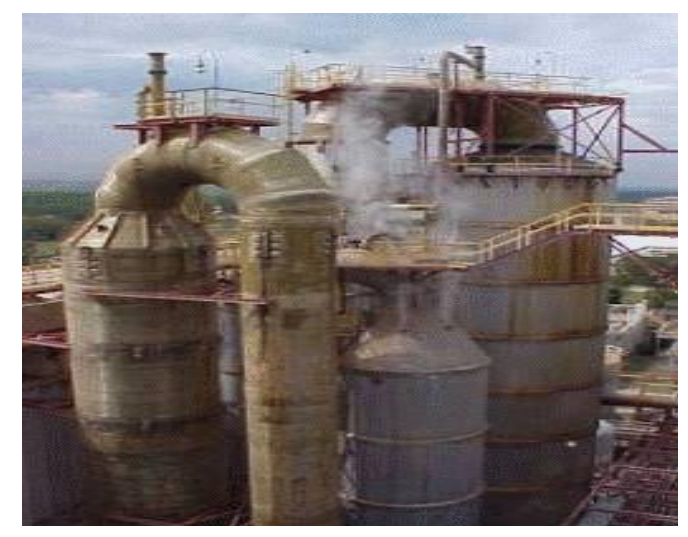

Fonte: International Paper do Brasil Ltda, 2011

No processo de branqueamento, aplica-se ozônio sobre a polpa para reduzir o número Kappa e aumentar o brilho, produzindo um efluente com menor carga de poluentes.

\subsubsection{Processo de produção do Papel}

A primeira etapa é representada pela preparação da celulose e dos sistemas auxiliares. A celulose branqueada é bombeada para o setor da preparação da massa da máquina de papel, com uma consistência de cerca de $3 \%$. Adiciona-se então, um espessante para aumentar a consistência da polpa para cerca de 5\%.

A partir da adição do espessante, a polpa é bombeada para os separadores centrífugos para remover possíveis contaminantes pesados, protegendo, assim, os 
refinadores, que participam da próxima etapa. Nessa etapa, a polpa é refinada nos refinadores para que as fibras adquiram características físicas adequadas. Em seguida, a massa refinada é armazenada num tanque onde recebe outros produtos químicos que fazem parte da formulação do papel.

A próxima etapa se concretiza nas máquinas de papel (MP1 e MP2) que são caracterizadas por apresentar uma caixa de fluxo pressurizada para alta velocidade. $O$ acionamento da máquina é seccional com motores de corrente contínua. Para a operação e manutenção, dois guindastes são usados com autonomia de até 30 toneladas cada.

Em seguida, o rolo de papel removido da máquina é levado para a prateleira dos alimentadores de rolos da rebobinadeira. Nesta, o rolo é dividido em bobinas de tamanhos e diâmetros combinados pela ação de lâminas rotativas. Os carretéis preparados são pesados em balanças embutidas no chão e levados por um sistema de transporte para o elevador.

A produção do papel cortado ou em rolos, depende do mercado consumidor. A capacidade das máquinas para o papel cortado é de $60 \%$ da produção e para rolos é de $100 \%$.

A máquina de enrolamento da bobina tem uma capacidade para embalar até 1.600 rolos por dia, abrangendo toda a produção diária. Uma estação para vincar o papel e outra para colagem permite a embalagem adequada. Através de um controle de peso, o equilíbrio é alcançado e também a completa identificação da produção.

\section{Figura 12 Máquinas de papel}

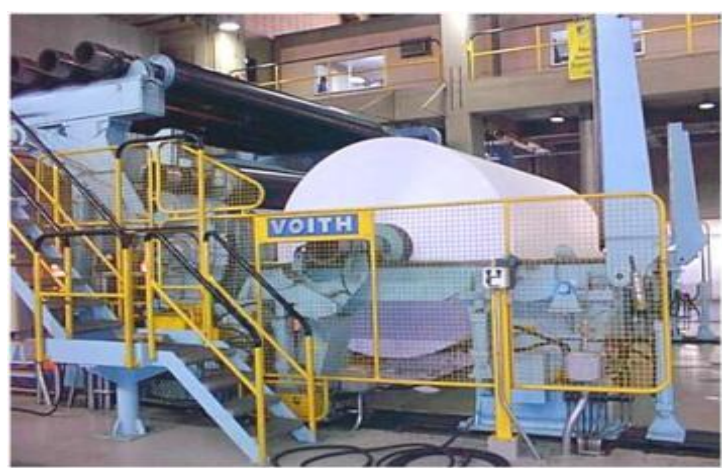

Fonte: International Paper do Brasil, 2011.

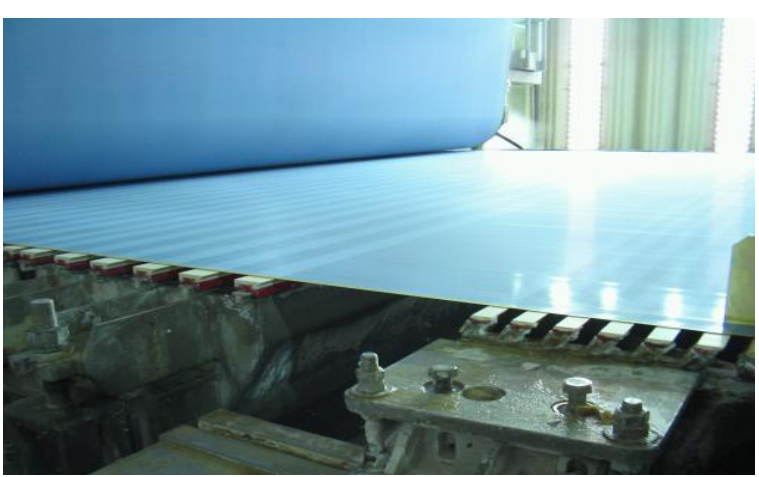

As bobinas defeituosas são reutilizadas em uma rebobinadeira e as tiras cortadas produzidas são pneumaticamente direcionadas para a máquina de papel MP1. Para o corte de formatos pequenos e empacotamento automático de resmas, são usadoas Crosscutters de $1.600 \mathrm{~mm}$ de largura e um sistema especial de cortes. As tiras dos cortadores são pneumaticamente transportadas para a rebobinadora da máquina de papel. 
Figura 13 Algumas fases do setor de acabamento
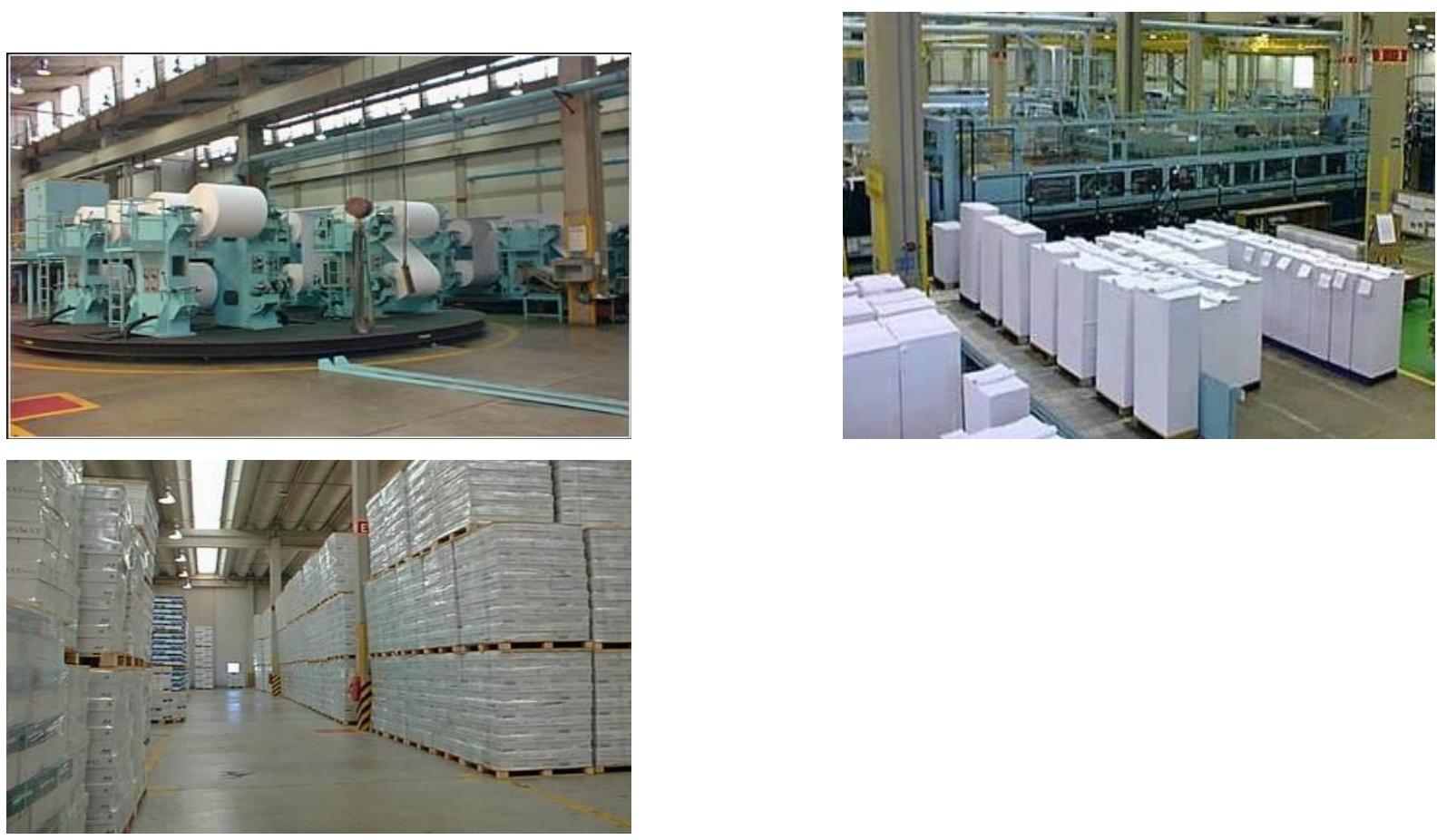

Fonte: International Paper do Brasil, 2011

\subsection{Considerações sobre os critérios exigidos para a obtenção do Flower e apresentação dos resultados obtidos pela fábrica de Luiz Antônio.}

Os critérios ambientais adotados pelo Programa de Rotulagem Ambiental da União Européia para o papel para cópia e impressão foram estabelecidos para promover a rotulagem ambiental e proporcionar impacto ambiental menos acentuado do processo produtivo. Os objetivos, de forma geral são:

- Reduzir as descargas de substâncias tóxicas e eutróficas no meio aquático;

- Reduzir os danos e riscos para o ambiente relacionados com a utilização de energia (aquecimento global, acidificação, destruição da camada de ozônio, esgotamento de recursos não renováveis) por meio da diminuição do seu consumo e das consequentes emissões para a atmosfera;

- Reduzir os danos e riscos para o ambiente relacionados com a utilização de produtos químicos perigosos e;

- Aplicar princípios de gestão sustentável para proteger as florestas.

De acordo com Flower (2002), são indicados requisitos específicos de avaliação e verificação para cada critério. A apresentação de declarações, documentação, análises, relatórios de ensaios e outras provas para demonstrar a conformidade com os critérios estabelecidos devem ser realizada pelo fabricante e/ou seus fornecedores. 
Ressalta-se que a metodologia utilizada para o cálculo de conformidade com os critérios assim como os cálculos específicos feitos pela International Paper do Brasil, podem ser encontrados na página eletrônica: www.internationalpaper.com

Os critérios ambientais analisados foram definidos pelo Comitê do Programa de Rotulagem Ambiental da União Européia em 2011. Esses mesmos critérios foram avaliados e modificados pelo referido Comitê em 2014, pois é feita revisão de três em três anos para possíveis alterações dos valores estabelecidos. Na ocasião foram estabelecidos novos valores para alguns critérios.

A fábrica de Luiz Antônio começou a preparação para a avaliação de seu processo produtivo pelos técnicos do Flower em 2009, pois foram feitas algumas modificações nas linhas de produção com o objetivo de alcançar os valores estabelecidos para a obtenção do rótulo ambiental europeu. Os dados utilizados para os cálculos são relativos ao ano de 2009. A metodologia indicada pelo Flower encontra-se na página: www.ec.europa.eu/environment/ecolabel/documents/usermanual paper.pdf

\subsubsection{Critérios considerados no processo de avaliação da fábrica de Luiz Antônio}

\subsubsection{Emissões para a água e para a atmosfera}

\subsection{Demanda química de Carbono Orgânico Dissolvido (CDO), Enxofre (S) e Óxidos de Nitrogênio $\left(\mathrm{NO}_{\mathrm{x}}\right)$}

Importante ressaltar que as emissões para a àgua são compostas por carbono orgânico dissolvido (CDO) enquanto que as emissões para o ar são compostas por enxofre (S) e Óxidos de Nitrogênio $\left(\mathrm{NO}_{\mathrm{X}}\right)$.

Para cada um desses parâmetros, conforme metodologia em anexo, as emissões para a água e/ou atmosfera provenientes da produção da celulose e da produção de papel são expressas em termos de pontos $\left(\mathrm{P}_{\mathrm{CDO}}, \mathrm{P}_{\mathrm{S}}, \mathrm{P}_{\mathrm{NOX}}\right)$, conforme indicado a seguir:

Individualmente, os pontos $\left(P_{C D O}, P_{S}, P_{\text {NOX }}\right)$, não podem exceder 1,5 , enquanto que 0 total de pontos $\left(\mathrm{P}_{\mathrm{TOTAL}}=\mathrm{P}_{\mathrm{CDO}}+\mathrm{P}_{\mathrm{S}}+\mathrm{P}_{\mathrm{NOX}}\right)$ não pode exceder 3,0 .

Durante o processo de avaliação feita pelos auditores, o fabricante deve fornecer os cálculos pormenorizados que provem a conformidade com esse critério, em conjunto com a documentação de apoio relacionada que inclua relatórios de ensaio usando os seguintes métodos de teste CDO: ISO 6060, $\mathrm{NO}_{\mathrm{x}}$ ISO 11564, S EPA/8; EPA 16ª , teor de S nos combustíveis líquidos ISO 8754/1995; teor de S no carvão ISO351.

A documentação de apoio deve indicar a frequência de medição e incluir o cálculo dos pontos para o CDO, $\mathrm{S}$ e $\mathrm{NO}_{\mathrm{x}}$, bem como todas as emissões de $\mathrm{S}$ e $\mathrm{NO}_{\mathrm{x}}$ verificadas 
durante a produção de celulose e do papel, incluindo o va[por gerado no exterior da fábrica, exceto se essas emissões estiverem relacionadas com a produção de eletricidade. As medições devem incluir as caldeiras de recuperação, os fornos de cal, as caldeiras de produção de vapor e as fornalhas de destruição de gases de cheiro intenso.

Quadro 4.2 Valores de referência para emissões da produção de diferentes tipos de celulose e papel

\begin{tabular}{|l|c|c|c|}
\hline \multicolumn{1}{|c|}{ Classe da polpa/papel } & DQO (referência) & S (referência) & NO $_{\mathbf{x}}$ (referência) \\
\hline $\begin{array}{l}\text { Pasta Química (Kraft e todas as } \\
\text { outras exceto processo ao sulfito) }\end{array}$ & 18,0 & 0,6 & 1,6 \\
\hline Pasta química - processo ao sulfito & 25,0 & 0,6 & 1,6 \\
\hline CTMP & 15,0 & 0,2 & 0,3 \\
\hline TMP/Pasta de madeira triturada & 3,0 & 0,2 & 0,3 \\
\hline Pasta de fibra reciclada & 2,0 & 0,2 & 0,3 \\
\hline $\begin{array}{l}\text { Papel (fábricas não integradas em que } \\
\text { todas as pastas usadas são } \\
\text { adquiridas no mercado) }\end{array}$ & 1,0 & 0,3 & 0,8 \\
\hline Papel (outras fábricas) & 1,0 & 0,3 & 0,7 \\
\hline
\end{tabular}

Fonte: FLOWER, 2002

O Quadro 4.2 representa os valores de referência para as emissões provenientes da produção de diferentes tipos de celulose e de papel para subsidiar o cálculo dos pontos acima referidos. As unidades referentes às emissões de Oxigênio, Enxofre e Óxidos de Nitrogênio estão em Kg/ADT.

Os valores obtidos pela fábrica de Luiz Antônio foram:

Quadro 4.3 Emissões de COD, Enxofre (S) e Oxidos de Nitrogênio (NO ${ }_{x}$ em Kg/ADT, em 2009.

\begin{tabular}{|l|c|c|c|c|}
\hline Tipo de Celulose & \% de Celulose & COD & S & NO $_{\mathbf{x}}$ \\
\hline $\begin{array}{l}\text { Método Químico (Kraft e outros, com } \\
\text { exceção do sulfito). }\end{array}$ & 100 & 4,37 & 0,32 & 0,82 \\
\hline
\end{tabular}

Fonte: International Paper do Brasil Ltda, 2012

Quadro4.4 Emissões de COD, Enxofre (S) e Oxidos de Nitrogênio (NO ${ }_{x}$ em Kg/ADT, em 2009.

\begin{tabular}{|l|c|c|c|}
\hline Tipo de Papel & COD & $\mathbf{S}$ & $\mathbf{N O}_{\mathbf{x}}$ \\
\hline $\begin{array}{l}\text { Produção integrada de Papel com abastecimento próprio de } \\
\text { celulose }\end{array}$ & 3,61 & 0,80 & 1,03 \\
\hline
\end{tabular}

Fonte: International Paper do Brasil Ltda, 2012 
Os resultados para as emissões para o ar e para a atmosfera, em termos de pontos, e calculados de acordo com a Decisão da Comissão da União Europeía de 04/09/2002 foram:

Quadro 4.5 Valores para as emissões em termos de pontos

\begin{tabular}{|c|c|c|}
\hline Indicadores & Valores International Paper & Valores de Referência \\
\hline $\mathrm{P}_{\mathrm{COD}}$ & 0,48 & $<=1,5$ \\
\hline $\mathrm{P}_{\mathrm{S}}$ & 1,38 & $<=1,5$ \\
\hline $\mathrm{P}_{\mathrm{NOX}}$ & 0,87 & $<=1,5$ \\
\hline $\mathrm{P}_{\mathrm{TOTAL}}$ & 2,73 & $<=3,0$ \\
\hline
\end{tabular}

Fonte: International Paper do Brasil Ltda, 2012

\subsection{Demanda Química de Compostos orgânicos halogenados (AOX)}

De acordo com o Flower (2002) as emissões de AOX provenientes da produção de cada tipo de celulose utilizada na produção do papel não podem exceder 0,25 $\mathrm{Kg} / \mathrm{TSA}$. Durante o processo de avaliação feita pelos auditores, o fabricante deve fornecer relatórios de ensaio, utilizando o método de ensaio AOX ISO 9562 (1989). A documentação de apoio deve indicar a frequência de medição.

Os compostos orgânicos halogenados apenas devem ser medidos em processos nos quais são utilizados compostos clorados para o processo de branqueamento da celulose. Não necessitam ser medidos nos efluentes provenientes da produção não integrada de papel nem nos efluentes provenientes da produção de celulose sem branqueamento ou em que o branqueamento seja efetuado com susbtâncias sem cloro.

As medições devem ser realizadas com amostras não filtradas e não sedimentadas, após tratamento na instalação ou em uma estação de tratamento de águas residuais coletiva. Os dados obtidos pela fábrica de Luiz Antônio foram:

Quadro 4.6 Emissões de compostos orgânicos halogenados AOX em Kg/ADT, em 2009.

\begin{tabular}{|l|c|c|}
\hline Tipo de celulsoe & Valor International Paper & Valor de referência \\
\hline $\begin{array}{l}\text { Método Químico (Kraft e outros, com } \\
\text { exceção do sulfito). }\end{array}$ & 0,0690 & $<=0,25$ \\
\hline
\end{tabular}

Fonte: International Paper do Brasil, 2012.

\subsubsection{Demanda de Dióxido de Carbono $\left(\mathrm{CO}_{2}\right)$}

As emissões de dióxido de carbono provenientes de fontes de energia não renováveis não podem exceder $1.000 \mathrm{Kg} /$ tonelada de papel produzido, incluindo as emissões provenientes da produção de eletricidade (no local ou no exterior) 
No caso das fábricas não integradas (em que toda a celulose utilizada é adquirida no mercado), as emissões não podem exceder $1.100 \mathrm{~kg}$ por tonelada. As emissões devem ser calculadas como a soma das emissões provenientes da produção da celulose e do papel.

Durante o processo de avaliação feita pelos auditores, o fabricante deve fornecer os cálculos pormenorizados que provem a conformidade com este critério, bem como a documentação de apoio relacionada. Devem ser apresentados os dados sobre as emissões de dióxido de carbono para a tmosfera incluindo todas as fontes de combustíveis não renováveis utilizadas durante a produção de celulose e do papel e as emissões provenientes da produção de eletricidade (no local ou no exterior).

No cálculo das emissões de $\mathrm{CO}_{2}$ provenientes dos combustíveis devem ser utilizados os seguintes fatores de emissão:

Quadro 4.7 Valores de referência para serem usados no cálculo das emissões de $\mathrm{CO}_{2}$

\begin{tabular}{|l|c|c|}
\hline \multicolumn{1}{|c|}{ Combustível } & Emissão de $\mathbf{C O}_{2}$ & Unidade \\
\hline Carvão & 95 & $\mathrm{gcO}_{2, \text { fóssil }} / \mathrm{MJ}$ \\
\hline Petróleo Bruto & 73 & $\mathrm{gcO}_{2, \text { fóssil }} / \mathrm{MJ}$ \\
\hline Óleo Combustível 1 & 74 & $\mathrm{gcO}_{2, \text { fóssil }} / \mathrm{MJ}$ \\
\hline Óleo Combustível 2-5 & 77 & $\mathrm{gcO}_{2, \text { fóssil }} / \mathrm{MJ}$ \\
\hline GPL & 69 & $\mathrm{gcO}_{2, \text { fóssil }} / \mathrm{MJ}$ \\
\hline Gás Natural & 56 & $\mathrm{gcO}_{2, \text { fóssil }} / \mathrm{MJ}$ \\
\hline Eletricidade da rede & 400 & $\mathrm{gcO}_{2, \text { fóssil }} / \mathrm{KWh}$ \\
\hline
\end{tabular}

Fonte: Flower, 2012

No que diz respeito à eletricidade de rede, o fabricante deve utilizar o valor constante do quadro acima, que representa a média européia, em seus cálculos, exceto se apresentar documentação que estabeleça o valor médio para os seus fornecedores. Nesse caso, poderá utilizar esse valor em vez do valor constante do quadro.

Os valores obtidos pela International Paper do Brasil foram;

Quadro 4.8 Valores referentes às emissões de $\mathrm{CO}_{2}$ em 2009

\begin{tabular}{|l|c|c|c|}
\hline \multicolumn{1}{|c|}{ Combustível } & Consumo & Emissões de $\mathbf{g C O}_{2 \text {,fóssil }}{ }^{*}$ & Valor de referência \\
\hline Carvão & - & - & - \\
\hline Óleo cru & - & - & - \\
\hline Óleo combustível & $2.290(\mathrm{KJ} /$ Ton $)$ & $177\left(\mathrm{Kg} \mathrm{CO}_{2} /\right.$ ton $)$ & - \\
\hline Óleo combustível 2-5 & - & - & - \\
\hline Gás Liquefeito (LPG) & - & - & - \\
\hline Gás Natural & - & - & 400 \\
\hline Eletricidade da Rede & $617(\mathrm{kWh} /$ ton $)$ & $247\left(\mathrm{Kg} \mathrm{CO}_{2} /\right.$ ton $)$ & $\mathbf{4 7 4}$ \\
\hline Total & & $\mathbf{4 2 4}$ & \\
\hline
\end{tabular}

Fonte: International Paper do Brasil, 2012.

* Emissões de $\mathrm{CO}_{2}\left(\mathrm{gCO}_{2, \text { fóssil }}\right)$, calculados por meio da Decisão da Comissão de 04/09/2002 


\subsubsection{Uso da Energia}

De acordo com Flower (2002) o consumo de eletricidade relacionado com a produção de celulose e a produção de papel devem ser expressos em termos de pontos $\left(\mathrm{P}_{E}\right)$ e o valor para o $\left(P_{E}\right)$ calculado deve ser inferior ou igual a 1,5.

No que diz respeito ao consumo de combustível para a produção de energia térmica relacionado com a produção de pasta de papel e a produção de papel deve ser expresso em termos de Pontos $\left(P_{C}\right)$, conforme indicado a seguir e o valor para o $\left(P_{C}\right)$ deve ser inferior ou igual a 1,5 .

Durante o processo de avaliação feita pelos auditores e relacionada com o consumo de energia elétrica e energia térmica, o fabricante deve fornecer os cálculos pormenorizados que provem a conformidade com este critério, bem como toda a documentação de apoio relacionada, incluindo os dados sobre o cosnumo total de eletricidade e de combustível.

No quadro 4.9, a seguir, se encontram os valores de referência para o cálculo da eletricidade e do combustível.

O fabricante deve calcular todas as necessidades energéticas incluindo a energia utilizada no processo de descoloração de papel usado para a produção de papel reciclado, separando a energia térmica/combustíveis da eletricidade durante a produção de celulose e de papel. A energia utilizada no transporte de matérias primas, bem como a conversão e embalagem, não é incluída nos cálculos de consumo de energia.

Quadro 4.9 Valores de referência para a eletricidade e o combustível

\begin{tabular}{|l|c|c|}
\hline \multicolumn{1}{|c|}{ Tipo de pasta } & $\begin{array}{c}\text { Combustível } \\
\text { (kWh/ADTF) } \\
\text { referência }\end{array}$ & $\begin{array}{c}\text { Eletricidade } \\
\text { (kWh/ADTE) } \\
\text { referência }\end{array}$ \\
\hline Pasta química & 4.000 & 800 \\
\hline Pasta mecânica & 900 & 2.500 \\
\hline Pasta de fibras recicladas & 1.800 & 800 \\
\hline $\begin{array}{l}\text { Papel fino sem fibras de madeira, não revestido. Papel de } \\
\text { revista (SC) }\end{array}$ & 1.800 & 600 \\
\hline $\begin{array}{l}\text { Papel fino sem fibras de madeira, revestido. Papel de } \\
\text { revista, revestido (LWC, MWC) }\end{array}$ & 1.800 & 800 \\
\hline
\end{tabular}

Fonte: Flower, 2012

O fabricante deve calcular todas as necessidades energéticas incluindo a energia utilizada no processo de descoloração de papel usado para a produção de papel reciclado, separando a energia térmica/combustíveis da eletricidade durante a produção de celulose e 
de papel. A energia utilizada no transporte de matérias primas, bem como a conversão e embalagem, não é incluída nos cálculos de consumo de energia.

A energia térmica total inclui todos os combustíveis adquiridos. Inclui igualmente a energia térmica recuperada através de processos realizados nas próprias instalações de incineração de licores ou resíduos (por exemplo, resíduos de madeira, serragem, licores, papéis usados, aparas), bem como o calor recuperado da produção interna de eletricidade. No entanto no cálculo de energia térmica total, o fabricante apenas necessita contabilizar $80 \%$ da energia térmica procedente dessas fontes.

Por energia elétrica entendem-se as entradas líquidas de energia proveniente da rede e a produção interna de eletricidade medida sob a forma de energia elétrica. A eletricidade utilizada para tratamento de águas residuais não necessita estar incluída. Nos casos em que o vapor é produzido usando a eletricidade como fonte de calr, o valor térmico do vapor deve ser calculado, dividindo por 0,8 e adicionando ao total do consumo de combustível.

$\mathrm{Na}$ fábrica de Luis Antônio a maior parte de vapor de alta pressão $\left(67 \mathrm{kgf} / \mathrm{cm}^{2}\right)$ gerado em caldeiras auxiliares e de recuperação passa por dois conjuntos de turbogeradores, tipo de extração $\left(12 \mathrm{kgf} / \mathrm{cm}^{2}\right)$ e pressão de retorno $\left(4.4 \mathrm{kgf} / \mathrm{cm}^{2}\right)$, que torna a pressão adequada para ser utilizada no processo.

Aproximadamente $10 \%$ do vapor de $67 \mathrm{kgf} / \mathrm{cm}^{2}$, é enviado para outras duas turbinas chamadas de T-40, para alimentar uma bomba de alimentação de caldeira de água e uma turbina para acionar o ventilador do evaporador. A redução da pressão que ocorre nos turbogeradores fornece geração de energia (cerca de 50\% das necessidades do processo).

\section{Figura 14 Caldeira Auxiliar e Turbogerador}
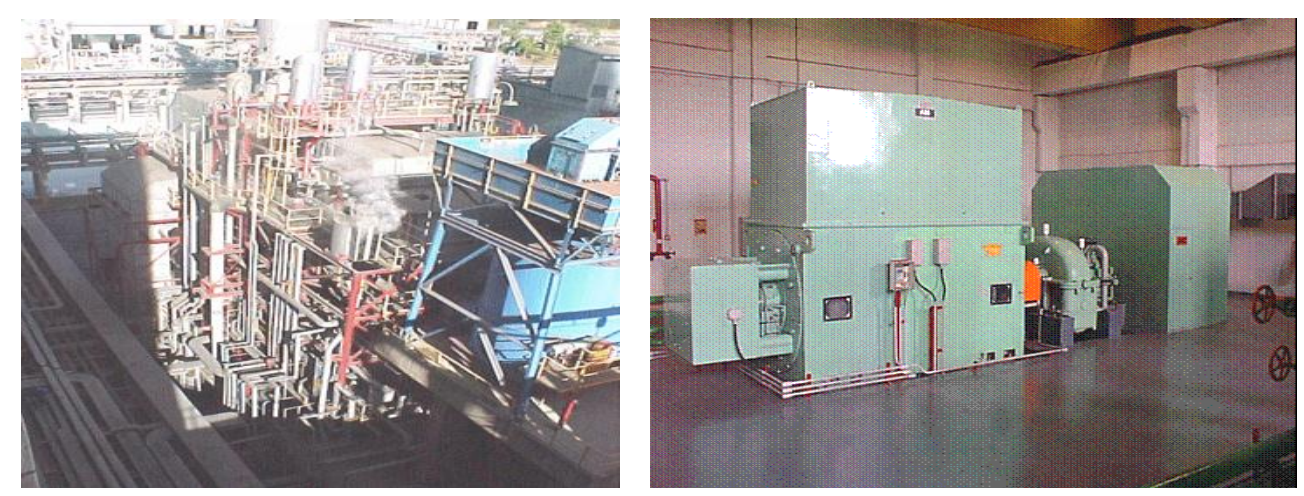

Fonte: International Paper do Brasil, 2011

A quantidade de energia adicional é adquirida a partir da rede, em regime paralelo. A alimentação é fornecida através de uma subestação de energia com 138 $\mathrm{KV}$. 
As caldeiras auxiliares produzem vapor para complementar a quantidade produzida na caldeira de recuperação, tal como exigido pelo processo de fabricação de celulose e de papel. Como fonte de energia para geração de vapor, podem ser queimados bagaço de cana, cascas, cavacos de eucalipto e óleo combustível.

Na caldeira auxiliar 1 e 2, os gases são encaminhados através de um multiciclone seguido de um precipitador eletrostático antes de ser liberado para a atmosfera. As cinzas de caldeiras auxiliares serão encaminhadas para o funil e enviadas para a unidade de compostagem.

Os valores obtidos pela fábrica de Luiz Antônio para o consumo de energia foram:

Quadro 4.10 Consumo de energia em KWh/ADT em 2009

\begin{tabular}{|l|c|c|c|c|c|}
\hline Tipo de celulose & \% celulose & $\begin{array}{l}\text { Eletricidade } \\
\text { produzida } \\
\text { internamente }\end{array}$ & $\begin{array}{l}\text { Eletricidade } \\
\text { Comprada }\end{array}$ & $\begin{array}{l}\text { Eletricidade } \\
\text { vendida }\end{array}$ & $\begin{array}{l}\text { Valor de } \\
\text { referência }\end{array}$ \\
\hline $\begin{array}{l}\text { Método Químico (Kraft e } \\
\text { outros, com exceção do } \\
\text { sulfito). }\end{array}$ & 100 & 650,01 & 55,45 & 0,00 & 800 \\
\hline $\begin{array}{l}\text { Tipo de Papel } \\
\text { Papel fino, não revestido } \\
\text { e papel para revistas. }\end{array}$ & - & 0,00 & 576 & 0,00 & 600 \\
\hline
\end{tabular}

Fonte: International Paper do Brasil, 2011

Quadro 4.11 Consumo de combustível para produção de energia térmica kWh/ADT em 2009

\begin{tabular}{|l|c|c|c|c|c|}
\hline Tipo de celulose & \% celulose & $\begin{array}{l}\text { Combustível } \\
\text { produzido } \\
\text { internamente }\end{array}$ & $\begin{array}{l}\text { Combustível } \\
\text { Comprado }\end{array}$ & $\begin{array}{l}\text { Combustível } \\
\text { vendido }\end{array}$ & $\begin{array}{l}\text { Valor de } \\
\text { referência }\end{array}$ \\
\hline $\begin{array}{l}\text { Método Químico (Kraft e } \\
\text { outros, com exceção do } \\
\text { sulfito). }\end{array}$ & 100 & 5.655 & 412 & 0,00 & 4.000 \\
\hline Tipo de Papel & & 879 & 332 & 0,00 & 1.800 \\
\hline $\begin{array}{l}\text { Papel fino, não revestido } \\
\text { e papel para revistas. }\end{array}$ & - & & & & \\
\hline
\end{tabular}

Fonte: International Paper do Brasil, 2012

O Quadro a seguir mostra os valores obtidos para $P_{E}$ e $P_{C}$ de acordo com a metodologia de cálculo indicada. 
Quadro 4.12 Valores para $\mathrm{P}_{\mathrm{E}}$ e $\mathrm{P}_{\mathrm{F}}$

\begin{tabular}{|c|c|c|}
\hline Indicadores & Valor obtido pela International Paper do Brasil Ltda & Valor de Referência \\
\hline$P_{E}$ & 0,92 & $<=1,5$ \\
\hline$P_{C}$ & 1,07 & $<=1,5$ \\
\hline
\end{tabular}

Fonte: International Paper do Brasil, 2011

\subsubsection{Fibras - Gestão sustentável das florestas}

De acordo com o Flower (2002), as fibras podem ser obtidas a partir de madeira, fibras recicladas de papel recuperado ou outras fibras celulósicas. As fibras provenientes de aparas das fábricas de papel não são consideradas fibras recicladas. Pelo menos $10 \%$ das fibras virgens obtidas a partir de madeira proveniente de florestas devem vir de florestas certificadas aplicando os princípios e medidas destinados a garantir a gestão sustentável das florestas.

As fibras virgens restantes obtidas a partir de madeira provenientes de florestas devem vir de florestas geridas de forma a aplicar os princípios e medidas destinados a garantir a gestão sustentável das florestas. É necessário indicar a origem de todas as fibras virgens utilizadas.

Ressalta-se que no Brasil, esses princípios e medidas devem corresponder, no mínimo, aos princípios para a gestão florestal da CNUAD (Rio de janeiro, junho de 1992) e quando aplicáveis aos critérios ou orientações para a gestão sustentável das florestas, de acordo com as respectivas iniciativas internacionais e regionais (OIMT, Processo de Montreal, Processo de Tarapoto, UNEP/FAODry-Zone Africa Initiative).

Durante o processo de avaliação feita pelos auditores o fabricante deve indicar 0 tipo, a quantidade e a origem das fibras utilizadas na produção de celulose e de papel. A origem das fibras virgens deve ser indicada com precisão suficiente para permitir, quando adequado, a realização de controles a fim de verificar se as fibras virgens são provenientes de florestas com gestão sustentável.

Sempre que forem utilizadas fibras virgens de provenientes de florestas, o fabricante deve apresentar os certificados relevantes em conjunto com a documentação de apoio que demonstre que o sistema de certificação avalia corretamente os princípios e medidas da gestão suastentável das florestas acima referidos.

Para as fibras virgens obtidas a partir de madeira proveniente de florestas que não são cetificadas como tendo uma gestão sustentável, o fabricante deve fornecer os documentos relevantes (cartas, códigos de conduta, declarações) que comprovem a conformidade com os requisitos acima referidos. 
No que diz respeito ao grupo IP, a realidade regional do uso da terra difere entre as zonas de operação da empresa, sendo predominante o cultivo da cana de açúcar e da laranja na região. O perfil predominante das áreas adjacentes é agrário, com alguns municípios destacando-se pelo nível de industrialização. As condições sócio-econômicas são evidenciadas pelo índice de IDH dos municípios (IDHM) e variam entre valores medianos $(0,500$ a 0,799$)$ e valores altos (maior ou igual a 0,800$)$.

Cabe ressaltar que a fábrica da International Paper do Brasil que participou do Projeto de Cooperação MDIC/SECEX/PNUMA/UE está localizada no município paulista de Luiz Antônio que possui uma área total de $59.761,70$ ha, da qual 8,40\% é ocupada pelas propriedades da International Paper. O município tem IDH de 0,795 , perfil agrário e o principal uso da terra inclui o cultivo da acana-de-açúcar.

As unidades de gestão da floresta da empresa estão localizadas na zona de transição dos biomas de savana (Cerrado) e Mata Atlântica, de acordo como Mapa da Vegetação Brasileira do IBGE. De acordo com representantes da empresa, as metas de manejo florestal visam garantir a produção sustentável de madeira para abastecer as unidades de produção do papel e da celulose, e assegurar o uso racional dos recursos florestais para a conservação dos ecossistemas naturais e para a sustentabilidade dos negócios florestais em curto, médio e longo prazo.

No que diz respeito à matéria prima, a empresa optou por trabalhar com a espécie $\mathrm{E}$. Grandis e E. Urophylla, devido ao potencial de crescimento mais elevado da primeira e maior adaptabilidade da segunda, bem como a possibilidade de formação híbrida entre estas duas espécies. Recentemente, três novas espécies foram introduzidas no programa de melhoramento florestal: E. Camaldulensis, E. Tereticornis e E. Globulus.

O processo de planejamento de produção florestal da International Paper compreende estratégias de fornecimento de madeira a curto, médio e longo prazo, indicando quanto, quando e onde colher e plantar a floresta. A tabela abaixo resume o planejamento para os últimos 5 anos.

QUADRO 4.13 Planejamento da produção florestal da International Paper do Brasil

\begin{tabular}{|l|c|c|c|c|c|}
\hline & $\mathbf{2 0 1 0}$ & $\mathbf{2 0 1 1}$ & $\mathbf{2 0 1 2}$ & $\mathbf{2 0 1 3}$ & $\mathbf{2 0 1 4}$ \\
\hline Área plantada (ha) & 7.973 & 9.500 & 9.500 & 8.500 & 8.500 \\
\hline Área coppice (ha) & 5.565 & 2.000 & 2.000 & 2.000 & 2.000 \\
\hline Volume $\left(\mathrm{m}^{3}\right)$ & 3.500 & 3.500 & 3.500 & 3.500 & 3.500 \\
\hline \% Própria $\left(\mathrm{m}^{3}\right)$ & $78 \%$ & $75 \%$ & $75 \%$ & $75 \%$ & $75 \%$ \\
\hline \% Leasing/Promoção $\left(\mathrm{m}^{3}\right)$ & $22 \%$ & $25 \%$ & $25 \%$ & $25 \%$ & $25 \%$ \\
\hline
\end{tabular}

Fonte: International Paper, 2011 
O inventário florestal contínuo tem como objetivo monitorar o crescimento da floresta de eucalipto e gerar estimativas confiáveis sobre o estoque de madeira atual, bem como sobre estoques futuros. Esta informação é a base para o planejamento estratégico de abastecimento das unidades de Mogi Guaçu e de Luis Antônio.

Já as atividades de topografia incluem a demarcação de estradas, de locais para a construção de estruturas de conservação do solo e a delimitação de áreas para Preservação Permanente e para Reserva Legal. As atividades do GIS compreendem elaboração de mapas para a análise de áreas e os seus eventos, tais como: monitoramento do plantio e da colheita, tipo de solo e a definição de áreas de conservação do meio ambiente e de estradas.

Para o reflorestamento, as mudas são produzidas no viveiro da empresa e estão aptas para ser plantadas em um período de 90 a 120 dias. As atividades de reflorestamento sâo feitas levando-se em consideração o princípio do mínimo tiliage que tem como premissas uma baixa interferência no solo para que se possa obter a sustentabilidade da floresta e produtividade.

O processo da colheita dos eucalíptos começa com as atividades de corte das árvores por volta dos 6-7 anos de idade e é seguido por delimbing, pelo arrastamento das árvores e finalmente pelas atividades de busca, carregamento e transporte.

As pesquisas visam desenvolver modelos de florestas plantadas que fornecem alta qualidade de matérias-primas para as unidades industriais da empresa, usando avançadas técnicas e princípios sustentáveis de produção florestal. Os principais grupos de pesquisa são:

A) Floresta Enhancement: A empresa tem um programa de contínua melhoria da floresta com áreas contendo populações que foram originadas de sementes diferentes para proporcionar o progresso nas gerações bem como para fornecer variabilidade ao programa comercial de clonagem e múltiplos usos da madeira.

B) Biotecnologia: A cultura de plantas in vitro é uma ferramenta eficiente para o processo em larga escala de produção de clonagem, permitindo que a empresa obtenha materiais fisiologicamente equilibrados e isentos de agentes patogênicos. O laboratório de cultivo é responsável pela produção de sementes para o Hydrogarden comercial.

C) Proteção Florestal: A qualidade das florestas pode ser influenciada por pragas e doenças, que comprometem o pleno desenvolvimento da plantação. A proteção florestal tem como objetivo prestar assistência técnica e dar apoio às áreas operacionais, treinamento pessoal e monitoramento da produção de mudas no viveiro e nas plantações de eucalipto da empresa, a fim de prevenir ou mitigar os danos causados por pragas e doenças. 
D) Gestão Florestal: Diz respeito ao uso e à gestão racional dos solos, combinando monitoramento, conservação e a manutenção da capacidade produtiva do solo, recomendando práticas de gestão apropriadas para cada situação.

A empresa possui as seguintes certificações:

Cerflor (Programa Brasileiro de Certificação Florestal): consiste em normas brasileiras de certificação para o manejo florestal e a cadeia de custódia. É gerenciado pelo Instituto Nacional de Metrologia, Normalização e Qualidade Industrial (Inmetro) e reconhecido pelo Programa para o Reconhecimento da Certificação Florestal (PEFC) organização não governamental dedicada a promover práticas florestais que respeitem preceitos ecológicos, sociais e éticos, e um dos maiores sistemas certificadores do mundo.

European Ecolabel Flower: criada em 1992, a certificação visa incentivar a sustentabilidade de produtos e serviços. Indica que o produto é fabricado de acordo com princípios de emissões atmosféricas, emissões hídricas, consumo de energia no processo produtivo, riscos ambientais relacionados ao uso de substâncias químicas perigosas e gestão de florestas sustentáveis.

Forest Stewardship Council (FSC): é uma organização não governamental internacional, representada no País pelo Conselho Brasileiro de Manejo Florestal. A missão do Conselho é difundir e facilitar o bom manejo das florestas brasileiras conforme Princípios e Critérios que conciliam as salvaguardas ecológicas com os benefícios sociais e a viabilidade econômica. Na década de 90 , tornou-se um dos selos com maior credibilidade no mundo e um dos mais importantes para o setor florestal. Representa hoje um indutor de boas práticas produtivas, por meio da valorização de produtos originados do manejo sustentável, que é transferido para a cadeia produtiva pelo número de Cadeia de Custódia e tem rastreada a origem florestal do produto transformado. A IP é membro associado do FSC Brasil desde 2010 e, em 2012, ingressou também no comitê de desenvolvimento de padrões dessa mesma organização.

ISO 9001: grupo de normas técnicas reconhecido internacionalmente que estabelece requisitos para o Sistema de Gestão da Qualidade (SGQ), agregando credibilidade aos processos internos da IP e aos seus produtos.

ISO 14001: conjunto de normas técnicas que busca estabelecer, com o envolvimento de toda a organização, um Sistema de Gestão Ambiental (SGA) que contribua com o equilíbrio entre rentabilidade e redução de impactos ambientais em todo o processo produtivo.

OHSAS 18001: é uma especificação de auditoria para o Sistema de Gestão de Saúde e de Segurança Ocupacional (SGSSO). Busca a promoção de um ambiente de trabalho saudável e seguro por meio da identificação e da mitigação de riscos relacionados. É compatível com as certificações ISO 9001 e 14001. 
A empresa tem a certificação ambiental ISO 14001 para o processo de produção florestal e programas de objetivos e metas ambientais, monitoramento da legislação ambiental aplicável, controles operacionais para gerenciar aspectos ambientais, bem como a monitorização do consumo de água, insumos agrícolas, emissões atmosféricas, efluentes, entre outros, de forma acomprovar o cumprimento da legislação e melhorar continuamente seu desempenho ambiental.

Quadro 4.14 Alguns Indicadores de Consumo de recursos e de Reciclagem em 2009

\begin{tabular}{|l|l|}
\hline Indicador & Consumo/Geração (2009) \\
\hline Consumo de água & $67.375,46 \mathrm{~m}^{3}$ \\
\hline Reciclagem & \\
\hline Metal & $47.986 \mathrm{Kg}$ \\
\hline Papel & $7.196 \mathrm{Kg}$ \\
\hline Bidro & $274 \mathrm{Kg}$ \\
\hline Plástico & $37.670 \mathrm{Kg}$ \\
\hline Total Reciclagem & $93.126 \mathrm{Kg}$ \\
\hline
\end{tabular}

Fonte: International Paper, 2009

A empresa, por meio de certificados e declarações confirmou que utiliza fibras de madeira para produzir papel e celulose com origem em florestas plantadas de eucalipto e certificadas pelo CERFLOR e pleo FSC. A quantidade plantada é de propiedade da própria empresa e totaliza $1.615 .465,56 \mathrm{M}^{3}$.

As informações específicas apresentadas pela International Paper do Brasil Ltda foram:

Quadro 4.15 Informações sobre o tipo de fibra utilizada pela fábrica de Luiz Antônio

\begin{tabular}{|l|c|}
\hline \multicolumn{1}{|c|}{ Tipo de fibra } & Percentagem de uso (\%) \\
\hline Fibras recicladas & 0,00 \\
\hline Fibras virgens de madeira com origem em florestas certificadas & 85 \\
\hline $\begin{array}{l}\text { Fibras virgens de madeira com origem em florestas com manejo } \\
\text { sustentável }\end{array}$ & 100 \\
\hline
\end{tabular}

Fonte: International Paper do Brasil Ltda, 2009

\subsubsection{Manejo de substâncias químicas perigosas}

De acordo com o Flower (2002) o fabricante deve fornecer uma lista dos produtos químicos utilizados na produção de celulose e de papel, em conjunto com documentação 
relevante (por exemplo, fichas de dados de segurança). Esta lista deve incluir a quantidade, a função e os fornecedores de todos os produtos químicos utilizados nos processos.

1 - Cloro

O cloro gasoso não pode ser utilizado como agente de branqueamento. Este requisito não se aplica ao cloro gasoso relacionado com a produção e utilização de dióxido de cloro.

O fabricante deve apresentar uma declaração que confirme que não foi utilizado cloro gasoso como agente de branqueamento

2- Etoxilatos de alquilfenol e outros derivados do alquilfenol (APEO)

Os etoxilatos de alquilfenol e outros derivados do alquilfenol não podem ser acrescentados a produtos químicos de limpeza ou de descoloração, agentes antiespumantes, agentes dispersantes ou agentes de revestimentos. Os derivados de alquilfenol são definidos como substâncias que quando se degradam produzem alquilfenóis.

O requerente deve fornecer uma declaração ou declarações de seusa fornecedores que confirme que não foram acrescentados APEO ou seus derivados nos produtos em causa.

\section{3- Monômeros residuais}

O teor total de monômeros residuais (excluindo a acrilamida) aos quais é atribuída ou pode ser atribuída qualquer das seguintes frases de risco ( ou combinações das mesmas)

R 45 - Pode causar cancro

R 46 - Pode causar alterações genéticas hereditárias

R49 - Pode causar cancro por inalação

R 50/53 - Muito tóxico para os organismos aquáticos, podendo causar efeitos nefastos em longo prazo, no ambiente aquático.

R 51/53 - Tóxico para os organismos aquáticos, podendo causar efeitos nefastos em longo prazo, no ambiente aquático.

R 52/53 - Nocivo para os organismos aquáticos, podendo causar efeitos nefastos em longo prazo, no ambiente aquático.

R 60 - Pode comprometer a fertilidade

R 61 - Risco durante a gravidez com efeitos adversos na descendência

O teor de acrilamida presente nos revestimentos, auxiliares de retenção, agentes de reforço, agentes hidrófugos ou produtos químicos utilizados no tratamento interno e externo das águas não pode exceder 1.000 ppm (calculado com base no seu conteúdo sólido).

O fabricante poderá se beneficiar de uma isenção em relação ao cumprimento desses requisitos no que se refere aos produtos químicos usados no tratamento externo das águas. 
O fabricante deve fornecer uma declaração de conformidade com este critério, em conjunto com documentação relevante (por exemplo, fichas de dados de segurança).

4- Biocidas

Os componentes ativos nos biocidas ou agentes bioestáticos usados para combater organismos que formam lodos nos sistemas de circulação da água que contêm fibras não podem ser potencialmente bioacumuláveis.

O fabricante deve fornecer uma declaração de conformidade com este critério, em conjunto com as fichas de dados de segurança pertinentes ou um relatório de ensaio, indicando o método de ensaio, o valor-limite e a respectiva conclusão, utilizando os seguintes métodos de ensaio: OCDE 107, 117 ou 305 A-E.

\section{5- Corantes azóicos}

Não podem ser utilizados corantes azoicos que possam ser decompostos em algumas das seguintes aminas aromáticas:

\section{Quadro 4.16 Aminas aromáticas proibidas}

\begin{tabular}{|l|c|}
\hline \multicolumn{1}{|c|}{ Amina Aromática } & CAS \\
\hline 4-Aminobifenilo & $(92-67-1)$ \\
\hline Benzidina & $(92-87-5)$ \\
\hline 4-cloro-o-toluidina & $(95-69-2)$ \\
\hline 2-naftilamina & $(91-59-8)$ \\
\hline 0-aminoazotoluene & $(97-56-3)$ \\
\hline 2-amino-4-nitrotolueno & $(99-55-8)$ \\
\hline 4-cloroanilina & $(106-47-8)$ \\
\hline 2,4-diaminoanisol & $(615-05-4)$ \\
\hline 4,4 diaminodiphenylmetano & $(101-77-9)$ \\
\hline $3,3-$ dicloro-benzidina & $(91-94-1)$ \\
\hline 3,3- dimetoxybenzidina & $(119-90-4)$ \\
\hline $3,3-$ dimetilbenzidina & $(119-93-7)$ \\
\hline $3,3-$ dimetil - 4,4 diaminodifenilmetano & $(838-88-0)$ \\
\hline p-cresidina & $(120-71-8)$ \\
\hline $4,4-$ metileno - bis (2 - cloroanilina) & $(101-80-4)$ \\
\hline $4,4-$ Oxidianilina & $(101-80-4)$ \\
\hline $4,4-$ tiodianilina & $(139-65-1)$ \\
\hline o-toluidina & $(95-53-4)$ \\
\hline 2,4 - diaminotolueno & $(95-80-7)$ \\
\hline 2,4,5 - trimetilanilina & $(137-17-7)$ \\
\hline 0 -anisidina & $(90-04-0)$ \\
\hline 4 - aminoazobenzeno & $(60-09-3)$ \\
\hline
\end{tabular}

Fonte: Flower, 2009 
O fabricante deve apresentar uma declaração de conformidade com este critério.

5 - Corantes

Não podem ser utilizados corantes comerciais, quer na produção de celulose, quer na produção de papel, às quais é atribuída ou possa ser atribuída na altura da candidatura qualquer uma das seguintes frases de risco (ou combinações das mesmas):

R 50 - Muito tóxico para os organismos aquáticos

R 51 - Tóxico para os organismos aquáticos

R 52 - Nocivo para os organismos aquáticos

R 53 - Pode causar efeitos nefatastos em longo prazo, no ambiente aquático.

Não podem ser utilizados corantes comerciais, quer na pasta de papel, quer no papel, que contenham mais de $2 \%$, em peso, de substâncias às quais é atribuída ou possa ser atribuída na altura da candidatura qualquer uma das seguintes frases de risco acima referidas (ou combinações das mesmas) em conformidade com a Diretiva 67/548/CEE e suas alterações subsequentes.

Este critério não se aplica a formulações em que a classificação se deve unicamente à presença de um ou vários componentes corantes com um grau de fixação igual ou superior a 98\%. Por grau de fixação entende-se o total da retenção de corantes pelas fibras no processo.

O fabricante deve fornecer uma declaração de conformidade com este critério, em conjunto com documentação de apoio relevantes como as fichas de dados de segurança pertinentes.

6 - Corantes e pigmentos de complexos metálicos

Corantes e pigmentos de complexos metálicos: Não podem ser utilizados corantes ou pigmentos à base de chumbo, de cobre, de cromo, de níquel ou de alumínio. Não obstante, podem ser usados corantes e pigmentos à base de ftalocianina de cobra.

O fabricante deve apresentar uma declaração de conformidade com este critério.

7- Impurezas iônicas nos corantes

O teor de impurezas iônicas dos corantes utilizados não pode exceder os seguintes valores; Ag 100ppm; As 50ppm; Ba 100ppm; Cd 20ppm; Co 500ppm; Cr 100ppm; Cu 250ppm; Fe 2500ppm; Hg 4ppm; Mn 1000ppm; Ni 200ppm; Pb 100ppm; Se 20ppm; Sb 50ppm; Sn 250ppm; Zn 1500ppm. O fabricante deve apresentar uma declaração de conformidade com este critério.

No que diz respeito à recuperação de produtos químicos na fábrica de Luis Antônio, ressalta-se que na unidade de evaporação, o licor contendo $15 \%$ de sólidos é concentrado até $70 \%$ por meio de um sistema de placas chamado de falling film.

Para a concentração do licor é usada baixa pressão de vapor. Há uma volta total do condensado para o sistema de água que alimenta as caldeiras. $\mathrm{O}$ condensado gerado pela 
evaporação da água do licor é dividido em dois grupos em relação ao conteúdo de compostos reduzidos de enxofre (TRS): de carga alta e de carga baixa. O condensado de carga baixa é reutilizado diretamente no processo de lavagem da polpa e o condensado de carga alta, depois de tratado, também é reutilizado no mesmo processo.

Os gases gerados na concentração do licor, juntamente com os gases da coluna de tratamento do condensado, são enviados para serem queimados. Há tanques para recolher toda a água contaminada e gerada por procedimentos como: transferências ocasionais, coletas de amostras, lavagem dos pisos da área de cozimento, lavagem da celulose e recuperação da caldeira.

A água desses tanques é bombeada para o tanque coletor na área de evaporação para posterior transmissão para a unidade de evaporação, para ser em seguida, reincorporada no processo. Os vapores contaminados a partir dos reservatórios de armazenagem de licor fraco ou forte são coletados e enviados para queima.

$\mathrm{Na}$ caldeira de recuperação o licor concentrado é bombeado para a caldeira para a queima, conforme figura 11. A queima da matéria orgânica do licor nesta caldeira fornece energia para a geração de vapor e de fusão dos sais de sódio, especialmente de carbonato de sódio. $O$ ar necessário para o processo de combustão do licor negro é fornecido por ação forçada e os gases são removidos por meio de ventiladores.

Antes da liberação dos gases para a atmosfera eles passam por um precipitador eletrostático que consiste em duas câmaras com três campos cada. Para manter as emissões de TRS em níveis adequados, três monitores contínuos são instalados: TRS, CO e $\mathrm{O}_{2}$. Com estes três monitores, é possível manter o funcionamento adequado do processo de combustão do licor e o controle das emissões.

O vapor gerado na caldeira de recuperação é enviado para o coletor de alta pressão de vapor e, a partir deste ponto, para os turbogeradores. O sódio fundido flue da caldeira por meio de calhas e então é dissolvido. A partir desta solução, surge o licor verde (solução de carbonato de sódio). Os vapores gerados no tanque de dissolução passam por um lavador "Venturi" para remover partículas antes de serem liberados para a atmosfera. $O$ material retido é enviado de volta para o tanque de dissolução.

Os materiais particulados formados por sais de sulfato de sódiom e advindos da caldeira e do precipitador de gás são adicionados ao licor negro antes de entrar na recuperação nacaldeira. 


\section{Figura 15. Recuperação da Caldeira}

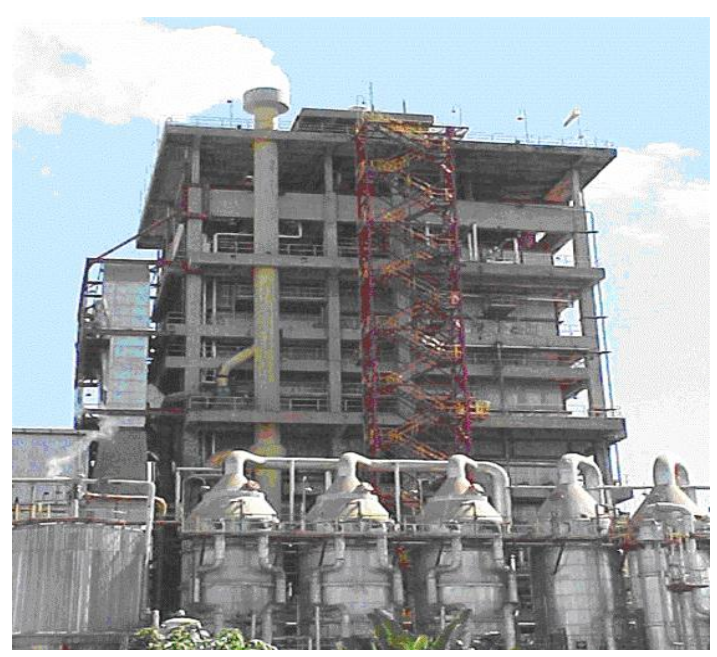

Fonte: International Paper do Brasil, 2011

No que diz respeito ao processo de causticação, seu objetivo é converter sais de carbonato de sódio em compostos ativos. Para isso, o licor verde que chega a essa área é enviado para um clarificador para a remoção de impurezas (sedimentos). Esses sedimentos são lavados para a remoção de alcalis e depois são desidratados. Os sedimentos com uma consistência de $40 \%$ são enviados para o sistema de compostagem enquanto que o filtrado é absorvido no processo de causticação.

O licor verde clarificado é então bombeado para o slaker de cal, que reage com a cal (óxido de cálcio). No slaker, o carbonato de sódio reage com o hidróxido de cálcio para formar hidróxido de sódio (licor branco e forte) e carbonato de cálcio insolúvel (lama de cal). Esta suspensão é conduzida para um clarificador.

Neste equipamento, o sobrenadante (licor branco) é bombeado para a área do digestor, para ser reutilizado. A partir da parte inferior do clarificador, a lama é bombeada para ser lavada, gerando uma solução fraca de álcali (licor branco e fraco) que é utilizada para dissolver o fundido na caldeira de recuperação e é armazenado nos silos de lama.

$\mathrm{Na}$ área de caustificação, a segunda fase de lavagem permite uma eficiência de 95\% para a remoção de álcalis a partir da lama que minimiza a quantidade presente de sulfeto de sódio na lama de cal e oferece boas condições de operação em área de calcinação em relação à questão de ATR, devido ao fato de a operação funcionar com lama de cal contendo um mínimo de sulfeto de sódio.

Nesta área existem canais e bombas de coleta de toda a água do andar para ser recuperada e re-injetada no processo. No Slaker de cal há um lavador com água a $45^{\circ} \mathrm{C}$ para remover particulados. No caso do Slaker de cal, há também a remoção de resíduos sólidos (grãos), que serão enviados para a área de compostagem. 
Figura 16. Área de caustificação

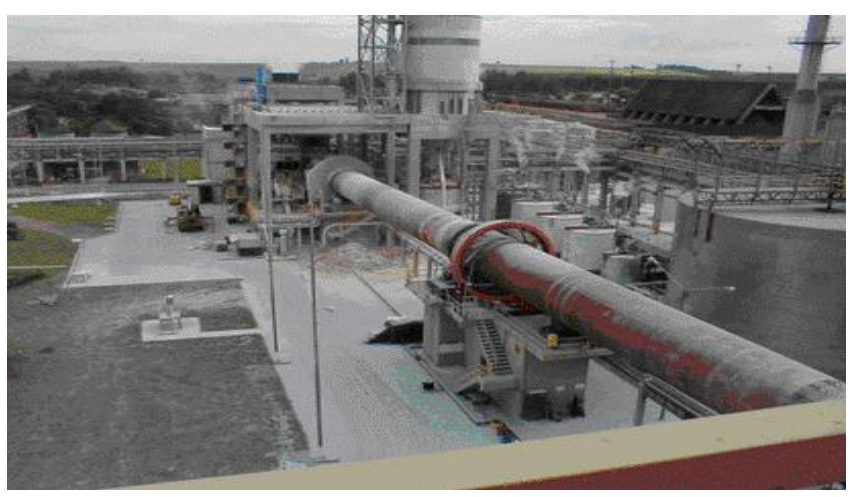

Fonte: International Paper do Brasil, 2011.

Já, a àrea de calcificação destina-se a converter o carbonato de cálcio (lama de cal) em óxido de cálcio. Para este fim, um forno rotativo é usado. A lama a partir do silo de armazenamento passa através de um filtro de vácuo, onde é devidamente lavada e condensada. O filtrado é usado na caustificação. A lama passa através de um secador ciclônico para aumentar a sua capacidade de secagem antes de serem alimentados no forno por meio de um parafuso.

Para fornecer a energia necessária para a calcinação são utilizados óleo combustível e metanol derivado dos sistemas de colunas de destilação. O ar necessário para o processo é fornecido com um ventilador de ar primário (cerca de $10 \%$ do total) e por redução da pressão, por meio de sistema de arrefecimento da cal produzida pela ação induzida de ventilação.

Os gases passam através de um precipitador eletrostático na saída do forno e em seguida, $20 \%$ do seu volume é enviado para a atmosfera enquanto que o restante é enviado para a unidade de carbonato de cálcio precipitado (PCC), que permite a recuperação do $\mathrm{CO}_{2}$ gerado. Os monitores contínuos de TRS, $\mathrm{CO}, \mathrm{SO}_{2}$ e $\mathrm{O}_{2}$ asseguram o funcionamento adequado do sistema de fornecimento de emissões de TRS ainda mais baixo do que o desejado.

O forno está equipado com queimador especial para permitir adequada oxidação térmica dos gases do processo de cozimento, evaporação e tratamento de condensado contaminado (decapagem), proporcionando um sistema alternativo de queima de gás.

Na unidade de Luis Antônio, as plantas de produtos químicos são;

1- Planta de Produção de Dióxido de Cloro

A planta de dióxido de cloro é integrada com a produção de ácido clorídrico e de clorato de sódio e usa o gás cloro somente como um reagente externo que não faz parte do processo produtivo da empresa. O cloro gasoso é utilizado para gerar o ácido clorídrico, que também utiliza o gás de hidrogênio a partir da eletrólise na fábrica de clorato de sódio. 0 
ácido clorídrico e a solução de clorato de sódio são enviados para o gerador de dióxido de cloro.

Os gases formados passam através de uma torre de absorção onde o dióxido de cloro é absorvido em água fria. Os gases restantes, que contêm principalmente cloro, passam por um separador de umidade e são então, enviados para a síntese de ácido clorídrico. A solução de dióxido de cloro é enviada para o armazenamento e a partir daí para a planta de branqueamento.

O cloro que pode, eventualmente, ser emanado pelo sistema de geração de dióxido de cloro, ou mesmo na sua descarga, é enviado para uma torre de absorção, onde existe uma solução de soda cáustica constantemente em processo de circulação. $\mathrm{O}$ hipoclorito de sódio que pode ser gerado nesta área é utilizado para cloração da água na estação de tratamento da água industrial (ETA).

Figura 17 Produção de Dióxido de Cloro

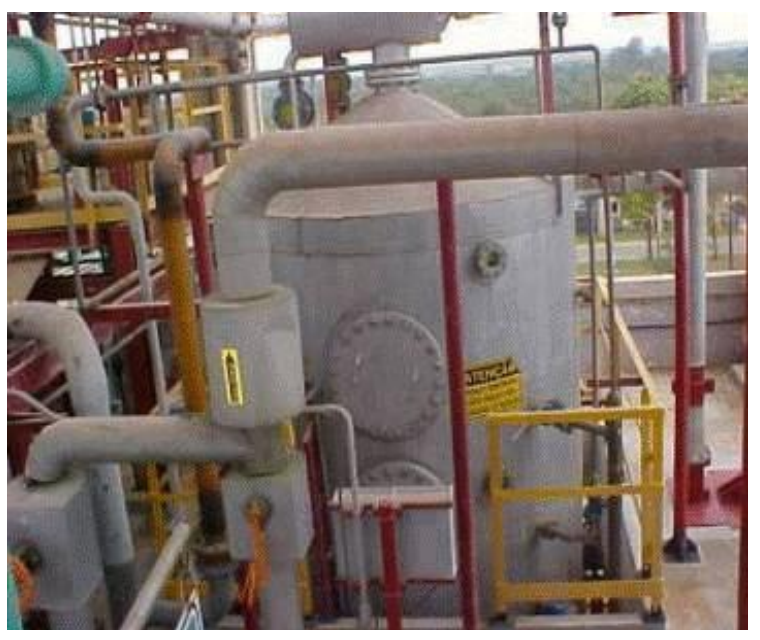

Fonte: International Paper do Brasil, 2011

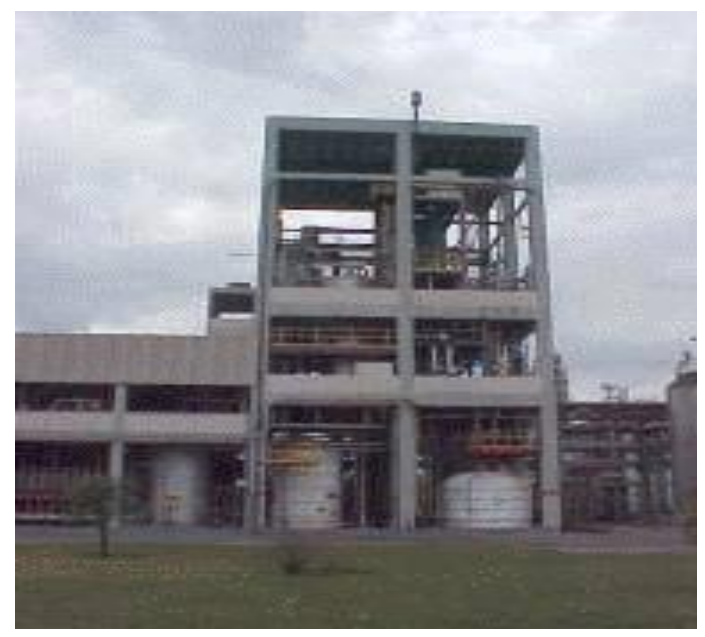

\section{2- Planta de Dióxido de Enxofre}

O dióxido de enxofre é produzido a partir de enxofre granulado. O enxofre é primeiramente aquecido com vapor e, em seguida bombeado para um forno para queima adequada. Em seguida, o gás de dióxido de enxofre é arrefecido e absorvido em água fria $\left(7^{\circ} \mathrm{C}\right)$ numa torre de absorção, formando desse modo a água sulfurosa.

A água sulfurosa é então armazenada e enviada para a planta de branqueamento com o objetivo de reduzir o dióxido de cloro residual presente na celulose depois do processo de branqueamento. 


\section{3- Planta de Oxigênio e Ozônio}

A capacidade da fábrica para produzir ozônio é de $180 \mathrm{~kg} / \mathrm{h}$ enquanto que para produzir oxigênio é de 55 toneladas/dia. Estas plantas foram construídas na área cedida pela International Paper para terceiros que vendem o produto para a empresa.

Ressalta-se que para preencher os requisitos exigidos pelo programa de Rotulagem Ambiental da União Européia sobre Produtos Químicos, a IP entregou uma lista de todos os produtos químicos que são utilizados pela fábrica, assim como seu nome técnico, utilização, o nome do fornecedor e o consumo anual. Foram listados os 52 produtos químicos utilizados pela empresa (em anexo).

\subsubsection{Gestão dos resíduos}

Todas as instalações de produção de pasta de papel e de papel devem dispor de um sistema de gestão dos resíduos (tal como definido pelas autoridades reguladoras competentes para as instalações de produção em causa) e dos produtos residuais resultantes da produção do produto a que é qtribuído o rótulo ecológico. O sistema deve ser documentado ou explicado na solicitação, que deve incluir informações pelo menos sobre os seguintes aspectos:

- Procedimentos para separar e utilizar materiais recicláveis do fluxo de resíduos;

- Procedimentos para recuperar materiais para outras utilizações, por exemplo, incineração para aproveitamento do vapor ou do calor nos processos de produção, ou fins agrícolas;

- Procedimentos para a gestão dos resíduos perigosos (tal como definido pelas autoridades reguladoras competentes para as instalações de produção de pasta de papel e de papel em causa).

O requerente deve fornecer uma descrição do sistema de gestão dos resíduos para a fábrica em análise e uma declaração de conformidade com este critério

Na International Paper do Brasil os resíduos sólidos gerados no processo industrial compreendem os resíduos provenientes da indústria de base florestal, os restos de transformações físicas mecânicas e químicas ou que não são incorporados no produto final.

As atividades da fábrica em Luis Antonio geram como resíduos provenientes do processo industrial da fabricação de celulose e papel pelo processo Kraft, os que se seguem:

A casca de toras de eucalipto que é removida durante a preparação da madeira; 
- $\quad$ As cinzas das caldeiras;

- $\quad$ Os cavacos de madeira que se perdem pelo processo;

- $\quad$ Grits (caustificação e forno de cal);

- $\quad$ Os resíduos de limpeza (resíduos da digestão);

- $\quad$ Os resíduos das grades do tratamento de águas residuais;

- $\quad$ Lama de efluentes da estação de tratamento (ETA);

- $\quad$ Lama de cal;

- $\quad$ Os resíduos em geral e;

- Lixo doméstico.

Nesses resíduos adiciona-se um valor médio anual de 70.000 toneladas de peso úmido. Considerando estes dados e a produção anual de celulose de 355 mil toneladas, a produção estimada de resíduos é $197 \mathrm{~kg} /$ tonelada de celulose, dentro do valor médio de resíduos gerados pelas fábricas brasileiras de papel e celulose.

A unidade de compostagem foi projetada para receber cerca de 70.000 toneladas de resíduos, base úmida/ ano, totalizando 5.833 toneladas de resíduos/mês e 194,4 toneladas de resíduos/dia. Estes valores são semelhantes aos do total de resíduos gerados na indústria.

Considerando que durante a compostagem, a massa e o volume serão reduzidos em $30 \%$, devido à perda de umidade e de carbono pela decomposição de matéria orgânica, presume-se que a quantidade de resíduos transformados em adubo será de 49 toneladas/ano, ou 4.083 toneladas/mês, ou ainda 136,1 toneladas/ dia.

Considerando uma aplicação no solo de $20 \mathrm{t} /$ ha (base úmida), a produção de compostagem estimada pode ser utilizada anualmente em até 2.450 hectares de áreas florestais, o que corresponde a $32 \%$ da área plantada com eucalipto no município de Luis Antonio, ou 15\% da área cultivada anualmente na região do município de Luis Antonio.

O processo de compostagem utilizado é o natural. Neste processo, o arejamento necessário para a estabilização de material orgânico ocorre por movimento giratório da pilha com o auxílio de uma máquina de compostagem.

O processo de compostagem utilizado é o natural. Neste processo, o arejamento necessário para a estabilização de material orgânico ocorre por movimento giratório da pilha com o auxílio de uma máquina de compostagem.

Este processo de arejamento ou de aeração consiste em colocar a água em contato estreito com uma fase gasosa (geralmente o ar) para transferir substâncias solúveis do ar para a água, aumentando seus teores de oxigênio e nitrogênio, e substâncias voláteis da água para o ar, permitindo a remoção do gás carbônico em excesso, do gás sulfídrico, do 
cloro, metano e substâncias aromáticas voláteis, assim como, proporcionar a oxidação e precipitação de compostos indesejáveis, tais como ferro e manganês. A aeração pode ser por gravidade, aspersão, difusão de ar ou forçada.

\section{Figura 18 Produção de compostagem}
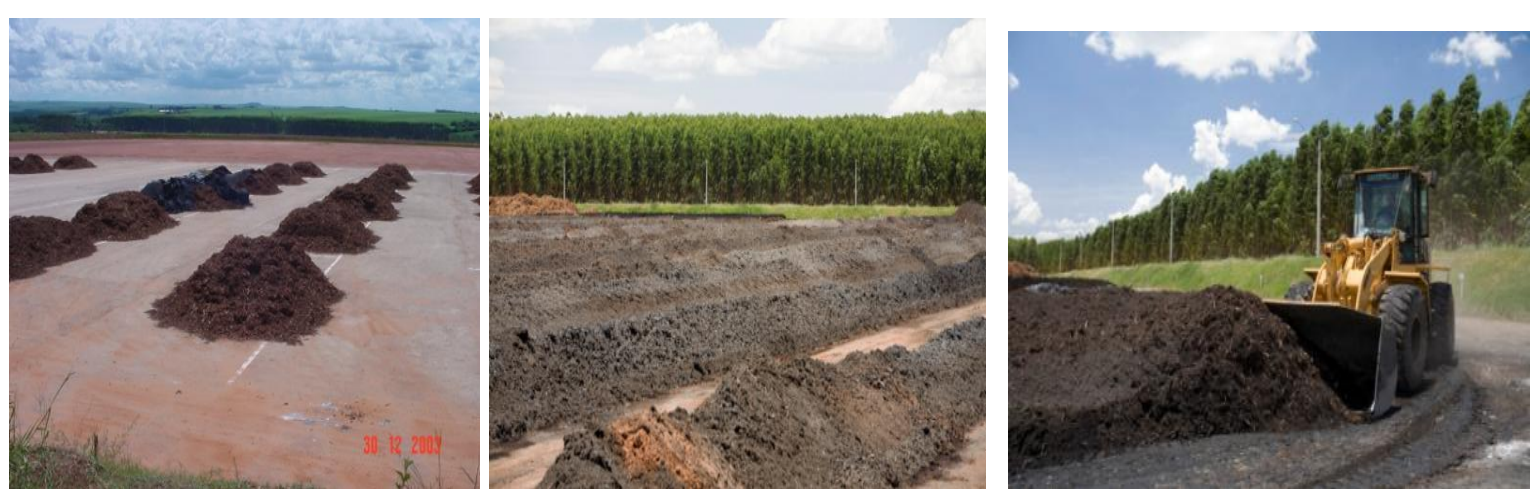

Fonte: International Paper do Brasil, 2011

Devido a esta técnica, o tempo para a estabilização da matéria orgânica depende do número de aparas a que a célula é submetida, variando geralmente de três a quatro meses. Durante este período, o processo de compostagem deve passar por três fases:

- Fitotoxicidade - primeira e última fase, com duração de 15 a 20 dias, quando o composto é cru ou imaturo. Tem lugar a formação de ácidos orgânicos e toxinas de curta duração.

- Semicura ou bioestabilização - o composto não é prejudicial às plantas e pode ser utilizado como fertilizante orgânico. Obtém-se após 30 a 60 dias dependendo do tamanho do material, do conteúdo de umidade inicial, do número de aparas, do tipo de equipamento utilizado, das dimensões celulares, etc..

- Humificação - ocorre depois de um período mais longo - de 90 a 120 dias. A cor do material torna-se mais escura. O composto atinge o auge de suas propriedades benéficas para o solo e para as plantas.

As operações realizadas durante o processo de compostagem compreendem desde a recepção dos resíduos até a conclusão da compostagem e são realizadas por seis funcionários do contratante sob a supervisão de um engenheiro florestal responsável. O processo de compostagem é dividido nas seguintes etapas:

(1) Recepção;

(2) Agrupamento dos resíduos;

(3) Início da compostagem;

(4) Monitoramento; 
(5) Conclusão da compostagem.

Com exceção dos resíduos clarificados e dos resíduos gerais, somente a lama de cal e o lixo doméstico têm destino diferente da estação de compostagem. A lama de cal é aplicada diretamente no solo cultivado com as florestas como um condicionador do solo enquanto que o lixo doméstico é enviado para o aterro municipal Luis Antonio.

As descrições detalhadas dos processos em que os resíduos são gerados são resumidas no Quadro, abaixo.

Quadro 4.17 Origem e destino dos resíduos gerados na fábrica da Luiz Antônio

\begin{tabular}{|l|l|l|}
\hline \multicolumn{1}{|c|}{ Resíduo } & \multicolumn{1}{c|}{ Origem } & \multicolumn{1}{c|}{ Destino } \\
\hline Cascas do Tambor & $\begin{array}{l}\text { Manejo da madeira e preparação dos } \\
\text { cavacos }\end{array}$ & Compostagem \\
\hline Cinzas caldeiras auxiliares & Queima da biomassa nas caldeiras & Compostagem \\
\hline $\begin{array}{l}\text { Sedimentos da } \\
\text { Paustificação }\end{array}$ & Processo de caustificação & Compostagem \\
\hline $\begin{array}{l}\text { Resíduos da calcificação processos } \\
\text { remoção }\end{array}$ & $\begin{array}{l}\text { Processo de caustificação } \\
\text { separação dos nós }\end{array}$ & Compostagem \\
\hline Lodo de esgoto & Tratamento de efluentes & Compostagem \\
\hline Resíduos da grade do ETA & Tratamento de efluentes & Compostagem \\
\hline Lama de cal das \\
calcinações & Forno de cal & Compostagem \\
\hline Resíduos Gerais & Diversas varreduras & áreas florestais \\
\hline Resíduos domésticos & Cafeteria, Restaurante & Compostagem \\
& & Aterro Municipalo de Luis \\
\hline
\end{tabular}

Fonte: International Paper do Brasil, 2009

Entre os resíduos que são enviados para a compostagem, o lodo da estação de tratamento da água é o maior contribuinte, com 33\% de massa seca (MS), seguido pela biomassa (cascas com 30\% de MS, escórias com 16\% de MS), pelas cinzas com 14\% de MS, pelos resíduos da estação de tratamento com $4 \%$ de MS e pelos resíduos em geral com de 3\% MS. Conforme dados do Quadro 4.18.

No que diz respeito ao Tratamento da água, ela é captada no rio Mogi Guaçu que corre ao lado da empresa e é bombeada para a Estação de Tratamento de Água (ETA). O processo de tratamento é o convencional, com a adição de cal hidratada e sulfato de alumínio ferroso seguido por decantação e filtração em filtros abertos de areia.

A lama dessa estação é enviada para um espessador de, na planta de tratamento de efluentes. A água após filtração é levemente clorada e é bombeada para toda a fábrica. A 
água utilizada na geração de vapor é desmineralizada, desarejada e em seguida, adequadamente condicionada para evitar problemas de corrosão e incrustação nas linhas de água, vapor e condensado.

Quadro 4.18 Geração Média Anual de resíduos sólidos

\begin{tabular}{|l|c|c|c|c|c|c|}
\hline Fonte & $\begin{array}{l}\text { Base } \\
\text { seca (\%) }\end{array}$ & $\begin{array}{l}\text { Base } \\
\text { úmida (\%) }\end{array}$ & $\begin{array}{l}\text { Volume } \\
(\%)\end{array}$ & $\begin{array}{l}\text { Base seca } \\
\text { (ton/ano) }\end{array}$ & $\begin{array}{l}\text { Base úmida } \\
\text { (ton/ano) }\end{array}$ & $\begin{array}{l}\text { Volume } \\
\text { (mªno) }\end{array}$ \\
\hline Cascas Tambor & 30,1 & 19,2 & 33,7 & 5,585 & 12,839 & 32,098 \\
\hline Cinzas caldeiras & 14,2 & 0,4 & 0,3 & 2,629 & 2,640 & 2,750 \\
\hline Sedimentos Caustificação & 15,1 & 2,8 & 22,6 & 2,807 & 5,160 & 4,195 \\
\hline Pó e areia da calcificação & 1,0 & 0,4 & 0,2 & 179 & 241 & 209 \\
\hline Resíduos remoções & 4,0 & 0,3 & 0,3 & 750 & 1,830 & 3,270 \\
\hline Lodo esgoto & 32,9 & 64,5 & 53,4 & 6,091 & 43,199 & 50,822 \\
\hline Resíduos da grade ETA & 2,7 & 0,2 & 2,0 & 500 & 1,030 & 1,883 \\
\hline Lama de cal calcinações & & & & 18,541 & 66,939 & 95,227 \\
\hline Resíduos Gerais & & & & 1,646 & 2,160 & 2,730 \\
\hline Resíduos domésticos & & & & 20 & & \\
\hline Total & & & & 20,207 & 69,129 & 97,957 \\
\hline
\end{tabular}

Fonte: International Paper do Brasil, 2011.

No que diz respeito ao tratamento das águas residuais, o efluente gerado em processos de fabricação de celulose e papel, sejam eles industriais ou sanitários, são coletados e enviados para a ETA, dimensionado para um caudal de $2850 \mathrm{~m}^{3} / \mathrm{h}$. Após o tratamento, os efluentes são lançados no rio Mogi Guaçu.

O Quadro, a seguir, apresenta os volumes esperados de geração de efluentes líquidos, de acordo com o projeto original.

Quadro 4.19 Volumes médios esperados nas águas residuais

\begin{tabular}{|l|c|}
\hline Pontos de geração & Fluidez $\left.\mathbf{( m}^{3} / \mathbf{d}\right)$ \\
\hline Utilidades/Recuperação & 3.900 \\
\hline Celulose & 36.800 \\
\hline Papel & 26.200 \\
\hline Outros & 300 \\
\hline
\end{tabular}

Fonte: International Paper, 2011.

O sistema adotado de tratamento de lamas biologicamente ativado difere de outros, uma vez que os efluentes são submetidos a duas etapas de arejamento. Os efluentes da fábrica de celulose e papel são enviados para o tanque de neutralização, onde recebem doses de solução de cal para a correção do pH. Depois de ajustar o pH (neutralização), o efluente é enviado para os tanques primários de sedimentação, onde ocorre a remoção dos 
sólidos em suspensão e parte da carga orgânica, com redução de 90\% e 10\%, respectivamente.

A lama removida do fundo dos tanques primários de sedimentação e a escória de superfície removida são enviadas para o tanque de lamas. O efluente é bombeado para uma torre de arrefecimento. Em seguida, o efluente é destinado à primeira fase do arejamento, onde são adicionados nutrientes como o azoto e o fósforo que são necessários para o desenvolvimento de microorganismos responsáveis pela biodegradação da matéria orgânica.

A incorporação de oxigénio é feita por difusores de fundo que são alimentados por sopradores de ar. A mistura contendo lodo biológico e efluentes é enviada por gravidade para os tanques de sedimentação da $1^{\text {a }}$ fase. Parte da lama formada volta para a entrada do tanque de arejamento por meio de uma bomba de parafuso, a fim de manter constante a concentração de microrganismos no tanque de arejamento.

Figura 19 Planta de tratamento de água

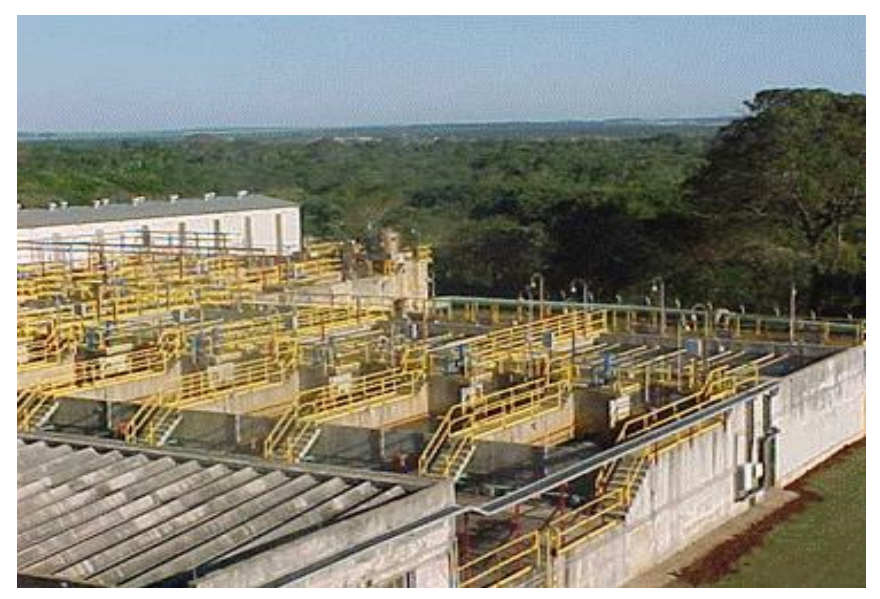

Fonte: International Paper do Brasil, 2011

O excesso de lama é bombeado para dentro do reservatório de espessamento e será desidratado. O efluente clarificado do espessador retorna por gravidade para 0 compartimento de efluente quente, enquanto que o efluente clarificado no primeiro estágio da lama ativada passa pela segunda fase de arejamento.

O efluente da primeira fase de tanques de sedimentação é enviado por gravidade para o tanque de aeração da $2^{\underline{a}}$ fase. Como na primeira fase, o oxigênio é introduzido por difusores de fundo que são alimentados por sopradores de ar.

O lodo de decantação primária vai diretamente para o tanque de lama. O excesso de lama biológica da sedimentação secundária da primeira e da segunda fase de aeração é encaminhado para o espessador de lama e a partir deste para o tanque de lama. 
A desidratação da mistura de lama primária e biológica é realizada com o auxílio de três prensas de desidratação.

\subsubsection{Aptidão do produto para o Uso}

O produto deve ser adequado ao uso.

O fabricante deve apresentar documentação relevante e/ou resultados de ensaios. A documentação adequada está em anexo.

\subsubsection{Informações que devem constar na embalagem do produto}

Figura 20 Embalagem da IP com o rótulo Ambiental

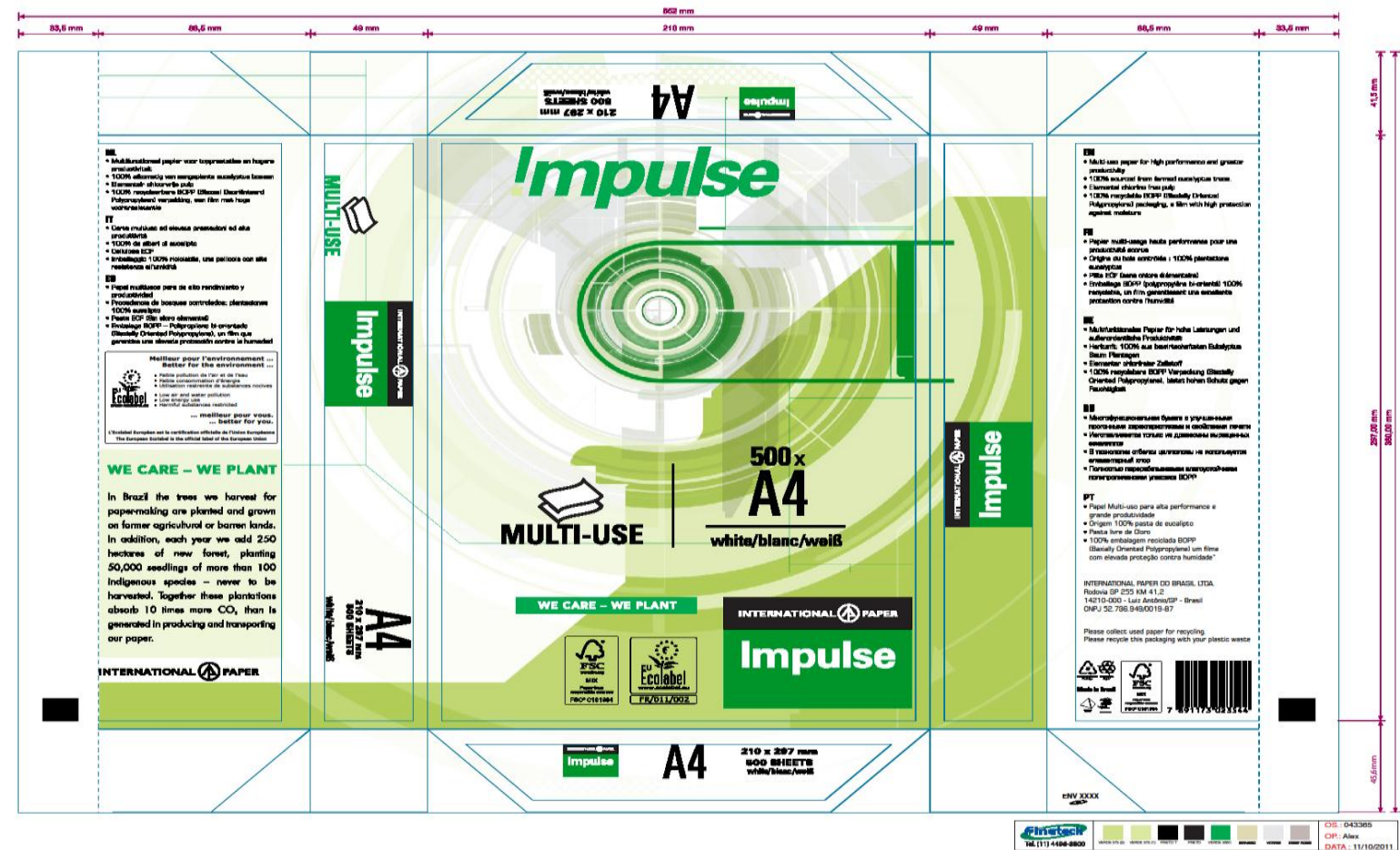

Fonte: International Paper do Brasil Ltda, 2012.

De acordo com Flower (2002) o produto deve ostentar o seguinte texto (ou equivalente) nas embalagens primária e secundária:

"Este produto se beneficia do rótulo ambiental porque preenche requisitos que, entre outros, diminuem as emissões para a água $(D Q O, A O X)$ e para a atmosfera $\left(S, N O_{x}, C O_{2}\right)$ e limitam a utilização de energia, combustíveis fósseis e substâncias perigosas."

Para mais informações sobre o rótulo ecológico consulte o site:

"Por favor, recolha o papel usado para reciclar." 
Além disso, o fabricante pode também indicar a percentagem mínima de fibras recicladas. O fabricante deve apresentar uma amostra da embalagem do produto em que seja visível o rótulo, em conjunto com uma declaração de conformidade com este critério.

\subsubsection{Informações que devem constar no Rótulo Ambiental}

Ao lado do rótulo ambiental deve ser impresso o seguinte texto:

Poluição do ar e da água reduzidas

Baixo consumo de energia

Utilização limitada de substâncias nocivas

O fabricante deve apresentar uma amostra da embalagem do produto em que seja visível o rótulo, em conjunto com uma declaração de conformidade com este critério.

\subsection{Análise dos dados obtidos no processo de rotulagem.}

O Quadro 4.20, a seguir, apresenta os critérios que foram avaliados pela empresa francesa de certificação AFNOR com os resultados obtidos pela fábrica de Luiz Antônio, do grupo IP.

Da análise da tabela pode-se concluir que a fábrica de Luiz Antônio atendeu a todos os critérios exigidos para obter o rótulo ambiental europeu. Importante notar que o Programa de Rotulagem Ambiental da União Européia é considerado um dos mais rigorosos do mundo e poucas empresas que não estão localizadas no continente Europeu possuem o Flower estampado nas embalagens de seus produtos. O Grupo International Paper do Brasil, por meio da fábrica de Luiz Antônio, foi a primeira empresa da América Latina a conseguir a certificação européia.

A comunicação do resultado positivo obtido pela empresa brasileira foi feita em junho de 2011 pelo grupo de auditoria francês AFNOR e o rótulo europeu passou a constar especificamente nas embalagens para exportação do produto nacional. No âmbito doméstico, a empresa também foi certificada pelo Programa de Qualidade Ambiental da ABNT, denominado colibri.

A ABNT participou de todas as atividades que envolveram o processo de obtenção do rótulo ambiental pela fábrica de Luiz Antônio e adotou os critérios utilizados pelo Flower para avaliar o papel para cópia e impressão como critérios que serão utilizados pelo Colibri. A intenção da ABNT em comum acordo com representantes do Projeto de Cooperação era facilitar o mecanismo de reconhecimento mútuo entre o Flower e o Colibri. 
Por meio desse processo de reconhecimento mútuo o produto nacional rotulado com o colibri poderia ser reconhecido no mercado francês como produto rotulado pelo Flower, já que os critérios utilizados pelos Programas de Rotulagem para conceder ambos os rótulos, são os mesmos.

Quadro 4. 20 Critérios avaliados e resultados apresentados pela fábrica de Luiz Antônio

\begin{tabular}{|l|l|l|l|}
\hline \multicolumn{1}{|c|}{ Critérios } & \multicolumn{1}{|c|}{ Valor IP } & Valor Referência & Status \\
\hline Emissões $\mathrm{COD}=\left(\mathrm{P}_{\mathrm{COD}}\right)$ & 0,48 & $<=1,5$ & Atendido \\
\hline Emissões $\mathrm{S}=\left(\mathrm{P}_{\mathrm{S}}\right)$ & 1,38 & $<=1,5$ & Atendido \\
\hline Emissões $\mathrm{NO}_{\mathrm{x}=}\left(\mathrm{P}_{\mathrm{NO}}\right)$ & 0,87 & $<=1,5$ & Atendido \\
\hline Emissões Totais $=\left(\mathrm{P}_{\mathrm{T}}\right)$ & 2,73 & $<=3,0$ & Atendido \\
\hline Emissões AOX & 0,0690 & $<=0,25$ & Atendido \\
\hline Emissões Totais $\mathrm{CO}_{2}\left(\mathrm{gCO}_{2, \text { fóssil })}\right)$ & 424 & 474 & Atendido \\
\hline Energia $\left(\mathrm{P}_{\mathrm{E}}\right)$ & 0,92 & $<=1,5$ & Atendido \\
\hline Energia $\left(\mathrm{P}_{\mathrm{C}}\right)$ & 1,07 & $<=1,5$ & Atendido \\
\hline Fibras Certificadas & $85 \%$ & $>=10 \%$ & Atendido \\
\hline Florestas Sustentáveis & $100 \%$ & $>=90 \%$ & Atendido \\
\hline Lista Produtos Químicos usados & $100 \%$ listados & $100 \%$ listados & Atendido \\
\hline Fichas de Segurança & $100 \%$ produtos & $100 \%$ produtos & Atendido \\
\hline Declaração fabricante sobre Cloro & Apresentou & Apresentar & Atendido \\
\hline Dados de Fornecedores & $100 \%$ fornecedores & $100 \%$ fornecedores & Atendido \\
\hline Reciclagem & Possui Programa & Programa próprio & Atendido \\
\hline Recuperação Resíduos & Possui Programa & Programa próprio & Atendido \\
\hline Gestão Resíduos Perigosos & Possui Programa & Programa próprio & Atendido \\
\hline Estação Tratamento água & Possui Instalação & Possuir Instalação & Atendido \\
\hline Uso Adequado do Produto & Apresentou Declaração & Declaração Específica & Atendido \\
\hline Informações na Embalagem & Apresentou Informações & Informações Específicas & Atendido \\
\hline Informações no Rótulo Ambiental & Apresentou Informações & Informações Específicas & Atendido \\
\hline Resultado & $100 \%$ critérios atendidos & $100 \%$ critérios atendidos & Atendido \\
\hline
\end{tabular}

Fonte: Elaboração própria, 2015.

Os resultados obtidos pela fábrica de Luiz Antônio foram bastante significativos notadamente àqueles relacionados com as emissões atmosféricas e para a àgua. Observase da Tabela 4.20 que as emissões constatadas de carbono orgânico dissolvido (COD) corresponderam a $32 \%$ do valor de referência. Enquanto que os valores auferidos para as emissões contendo enxofre (S) e óxidos de nitrogênio ( $\mathrm{NO}_{\mathrm{x}}$ corresponderam a $92 \%$ e 58\% dos valores de referência, respectivamente.

Valores significativos também foram observados para os referentes às emissões de compostos orgânicos halogenados $\left(\mathrm{AO}_{\mathrm{x}}\right)$ e às emissões totais de gás carbônico $\left(\mathrm{CO}_{2}\right)$ que 
alcançaram $27,6 \%$ e $89,4 \%$ dos valores de referência, respectivamente. Importante ressaltar que no grupo de compostos orgânicos halogenados encontram-se os compostos derivados do cloro que são na sua maioria, tóxicos para a saúde humana e que foram banidos dos processos produtivos da indústria de celulose e papel ainda na década de 1980. No que diz respeito ao gás carbônico $\left(\mathrm{CO}_{2}\right)$, é considerado um dos principais gases causadores do efeito estufa e das alterações climáticas.

Os bons resultados obtidos pela IP nesses critérios demonstram que a preocupação do setor de papel e celulose com as questões climáticas e com a poluição de recursos hídricos, não é recente e deriva principalmente da forte pressão da opinião pública que esse setor recebeu a partir do fim da década de 1970 e início da década de 1980 quando impactos ambientais negativos foram associados com as empresas desse setor.

Muitos autores afirmam que o setor de papel e celulose foi um dos pioneiros na adoção dos princípios estabelecidos pela ME, ainda no início da década de 1980 como uma reação à pouca efetividade das tecnologias de fim de tubo que o setor adotava na época. $\mathrm{A}$ substituição dos compostos derivados do cloro por compostos menos agressivos ao meio ambiente e a transformação do licor negro, que era um resíduo do processo produtivo, em fonte de energia, além de outras iniciativas preventivas, ilustram o processo de modernização do setor.

No que diz respeito ao desempenho da fábrica de Luiz Antônio em relação ao critério que avalia o consumo de energia elétrica e o consumo de energia advinda de outros combustíveis, também foi considerado satisfatório já que correspondeu a $61,3 \%$ e 71,3\% dos valores de referência, respectivamente.

Esses critérios são considerados extremamente importantes para que a empresa obtenha o rótulo europeu, pois mostram se a empresa consegue economizar o recurso analisado e se seus processos produtivos são eficientes na medida em que consome menos energia por produto produzido que a quantidade estabelecida como satisfatória. A empresa brasileira apresentou economia de $38,7 \%$ no critério da energia elétrica e $28,7 \%$, no critério referente à energia advinda de outras fontes.

O desempenho da fábrica de Luiz Antônio no critério relacionado com a gestão e o uso de produtos químicos também foi positivo. Foram necessárias informações específicas sobre 52 produtos químicos utilizados pela empresa e que em sua maioria são produzidos por fornecedores ao longo da cadeia produtiva.

Além de representar dados que nem todas as empresas tornam públicos, o dossiê de produtos químicos mostrou que a fábrica de Luiz Antônio preenche requisitos outros que são exigidos pela União Européia. Trata-se do rigoroso Regulamento para Produtos Químicos da União Européia denominado REACH (Regulation, Evaluation and Autorization of Chemicals) que preve que toda substância química ou um produto que contenha uma 
substância química na sua constituição e que é exportado para a União Européia deve ser registrado pelos órgãos competentes europeus.

A fábrica de Luiz Antônio não é uma empresa exportadora de produtos químicos, mas, utiliza 52 substâncias químicas no processo produtivo do papel para cópia e impressão. Cada um desses produtos com seus respectivos fornecedores devem estar registrados na União Européia. Se o fornecedor não efetuou o oneroso registro, a empresa brasileira precisa fazê-lo.

\subsection{Análise e comparação do desempenho ambiental da fábrica de Luiz Antônio com outras fábricas do setor de papel e celulose.}

É feita, primeiramente, uma análise comparativa do desempenho ambiental da fábrica de Luiz Antônio com a fábrica de Mogi Guaçu, no estado de São Paulo, que também pertence ao grupo IP, mas que não se submeteu ao processo de obtenção do rótulo europeu.

A seguir os dados das empresas do grupo IP são comparados com os dados de duas empresas de outro grupo do mesmo setor de papel e celulose. Trata-se do Grupo Suzano Papel e Celulose e das fábricas das cidades de Limeira e Suzano, ambas no estado de São Paulo.

A fábrica de Mogi Guaçu inicalmente seria a candidata do grupo IP para participar do Projeto de Cooperação, mas uma análise preliminar da situação da fábrica mostrou que os dados relacionados com as emissões atmosféricas e o consumo de energia seriam reprovados pelos auditores do rótulo europeu.

O grupo IP resolveu então indicar a fábrica de Luiz Antônio que apresentava situação mais favorável aos requisitos exigidos para obtenção do Flower. Os representantes da empresa, cientes da necessidade de aprimoração do processo produtivo em Mogi Guaçu elaboraram um plano, em 2009, para modernizá-la que incluiu dentre outras iniciativas preventivas, a troca de uma caldeira movida a combustível fóssil (gás) por outra caldeira movida à biomassa.

O plano se concretizou em 2013 e pelos dados analisados, a seguir, os ganhos obtidos pelo grupo IP e pela fábrica de Mogi Guaçu, no que se referem ao consumo de energia e às quantidades emitidas para a atmosfera, são significativos.

Os indicadores analisados foram os únicos que estavam disponíveis e que permitiram a comparação entre as fábricas e os grupos.

Os dados obtidos para as fábricas do grupo Suzano Papel e Celulose foram obtidos na página eletrônica da BRACELPA, www.bracelpa.org.br, enquanto que os dados 
referentes às empresas do grupo IP foram obtidos da página eletrônica da International Paper do Brasil Ltda, www.internationalpaper.com

Ressalta-se que as quantidades de papel para imprimir e escrever que foram produzidas pelas fábricas do grupo IP e pelas fábricas do grupo Suzano Papel e Celulose, no período de 2009 a 2013, que foram utilizadas nos cálculos elaborados para a análise do desempenho das fábricas, encontram-se na tabela abaixo.

Quadro 4.21 Produção de papel para imprimir e escrever das fábricas do grupo IP e do grupo Suzano Papel e Celulose (mil ton).

\begin{tabular}{|c|c|c|c|c|}
\hline Ano/Fábrica & Luiz Antônio & Mogi Guaçu & Limeira & Suzano \\
\hline 2009 & 342.800 & 419.000 & 295.200 & 438.100 \\
\hline $\mathbf{2 0 1 0}$ & $\mathbf{3 6 0 . 0 0 0}$ & $\mathbf{4 4 0 . 0 0 0}$ & $\mathbf{3 1 0 . 0 0 0}$ & $\mathbf{4 6 0 . 0 0 0}$ \\
\hline 2011 & 357.120 & 436.480 & 307.520 & 456.320 \\
\hline 2012 & 351.000 & 429.016 & 306.013 & 448.516 \\
\hline 2013 & 349.280 & 426.913 & 304.513 & 446.318 \\
\hline 2014 & 348.370 & 425.800 & 303.721 & 445.157 \\
\hline
\end{tabular}

Fonte: Elaboração própria, 2015.

A produção real das unidades produtivas consideradas, não foi disponibilizada. Optou-se então, e por sugestão de representantes do setor de papel e celulose, utilizar as capacidades instaladas de cada uma dessas unidades para o ano de 2010 que foi considerado um bom ano para o setor. A partir desse valor, para o cálculo dos outros anos que compõem o período considerado, utilizou-se a variação apresentada pela produção brasileira de papel para imprimir e escrever, conforme tabela abaixo.

Quadro 4.22 Produção Brassileira de papel para imprimir e escrever

\begin{tabular}{|c|c|c|}
\hline Ano & Quantidade (Toneladas) & Variação (\%) \\
\hline 2009 & 2.575 .000 & - \\
\hline 2010 & 2.704 .000 & 5,0 \\
\hline 2011 & 2.680 .000 & $(0,88)$ \\
\hline 2012 & 2.634 .000 & $(1,71)$ \\
\hline 2013 & 2.621 .000 & $(0,49)$ \\
\hline 2014 & 2.614 .000 & $(0,26)$ \\
\hline
\end{tabular}

Fonte: BRACELPA, 2015.

\subsection{1 consumo de energia}

O consumo de energia de uma fábrica tem efeito direto nos custos operacionais e pode aumentar a exposição a flutuações de abastecimento e preços de energia. Atualmente, o tema representa um dos maiores custos do grupo IP no escopo industrial. Em linha com a relevância do assunto, a organização buscou melhoria contínua em eficiência energética. 
Todas as fábricas do grupo realizam o controle mensal de consumo de energia por meio de quatro indicadores, facilitando a comparação entre as unidades. São eles: a energia total consumida por quantidade de produto fabricado, a energia comprada por quantidade de produto fabricado, o custo de energia por quantidade de produtos fabricados e o custo de energia por quantidade de energia consumida. Assim, de acordo com os resultados obtidos, metas e planos de ação de mitigação são traçados.

Uma das soluções encontradas para aumentar a eficiência energética do processo produtivo foi a troca de equipamentos de alto consumo por outros mais eficientes. E com o objetivo da redução do consumo, o grupo IP investiu na aquisição de maquinários mais eficientes e na inclusão de uma caldeira de biomassa na fábrica de Mogi Guaçu.

A aquisição da caldeira movida à biomassa na fábrica de Mogi Guaçu foi consequência da obtenção do rótulo ambiental europeu pela fábrica de Luiz Antônio. A Diretoria do grupo IP decidiu estabelecer para a fábrica de Mogi Guaçu o mesmo patamar de qualidade ambiental alcançado pela fábrica de Luiz Antônio e já planejou para os próximos anos à submissão da fábrica de Mogi Guaçu aos processos de obtenção dos rótulos ambientais europeu e brasileiro.

De acordo com representantes do grupo IP, existem projetos também para a utilização de caldeiras de biomassa na unidade de Mato Grosso e nas unidades de embalagens do grupo. Medidas de curto prazo também incluem ações de aumento de eficiência energética.

O Quadro 4.23, a seguir, mostra os valores do consumo de energia das fábricas de Luiz Antônio (LA) e Mogi Guaçu (Mogi) referente ao período de 2011 a 2013.

Em relação à fábrica de Luiz Antônio houve uma diminuição constante no consumo total de energia. O valor economizado foi de 69.279 GJ, ou de $4,14 \%$, quando se considera o período analisado.

Quadro 4.23 Consumo de energia das fábricas do grupo IP em (GJ)

\begin{tabular}{|l|c|c|c|c|c|c|c|}
\hline \multicolumn{1}{|c|}{ Tipo } & R/NR & \multicolumn{2}{c|}{2011} & \multicolumn{2}{c|}{2012} & \multicolumn{2}{c|}{2013} \\
\hline Escopo Fabril & & LA & MOGI & LA & MOGI & LA & MOGI \\
\hline Óleo Combustível & NR & 813.795 & 670.232 & 765.295 & 722.117 & 731.362 & 693.450 \\
\hline Gás Natural & R & 0 & 3.301 .161 & 0 & 3.073 .079 & 0 & 171.406 \\
\hline $\begin{array}{l}\text { Eletricidade* } \\
\text { Rede Pública }\end{array}$ & R & 800.503 & 981.057 & 830.553 & 998.559 & 812.763 & 913.198 \\
\hline $\begin{array}{l}\text { Eletricidade-Rede } \\
\text { Pública }\end{array}$ & NR & 58.406 & 71.579 & 60.598 & 72.856 & 59.300 & 66.628 \\
\hline Total & & $\mathbf{1 . 6 7 2 . 7 0 4}$ & $\mathbf{5 . 0 2 4 . 0 2 9}$ & $\mathbf{1 . 6 5 6 . 4 4 6}$ & $\mathbf{4 . 8 8 6 . 6 1 1}$ & $\mathbf{1 . 6 0 3 . 4 2 5}$ & $\mathbf{1 . 8 4 4 . 6 8 2}$ \\
\hline
\end{tabular}

Fonte: Relatorios de sustentabilidade (www.internationalpaper.com)

Onde; $R$ = Renovável e NR = Não Renovável

*A eletricidade é adquirida da rede pública, cuja fonte é distribuída de acordo com a matriz energética brasileira. . 
Com relação à fábrica de Mogi Guaçu, nos dois primeiros anos analisados, observase que o consumo de energia manteve-se em nível bastante elevado e diminuiu significativamente no ano de 2013, quando entrou em funcionamento a caldeira movida à biomassa. No período 2011 a 2013 a economia de energia foi de $3.179,347$, ou $73,4 \%$.

Com a construção da nova caldeira movida à biomassa, a fábrica de Mogi Guaçu passou então a ter um desempenho energético muito próximo do desempenho da fábrica de Luiz Antonio. Este fato pode ser considerado como um benefício direto da aplicação da ME e o uso de um de seus instrumentos, a rotulagem ambiental na fábrica de Luiz Antonio que motivou a modernização da fábrica de Mogi Guaçu.

O Quadro 4.24, abaixo mostra o consumo de energia por quantidade, em toneladas de papel produzido pelas fábricas do grupo IP. O período considerado é de 2011 a 2013.

Quadro 4.24 Consumo de energia das fábricas do Grupo IP em (Gj/t de papel)

\begin{tabular}{|l|c|c|c|c|c|c|}
\hline \multicolumn{1}{|c|}{ Tipo } & \multicolumn{2}{c|}{2011} & \multicolumn{2}{c|}{2012} & \multicolumn{2}{c|}{2013} \\
\hline \multicolumn{1}{|c|}{ Escopo Fabril } & LA & MOGI & LA & MOGI & LA & MOGI \\
\hline Total energia consumida & 1.672 .704 & 5.024 .029 & 1.656 .446 & 4.886 .611 & 1.603 .425 & 1.844 .682 \\
\hline Produção média papel & 357.120 & 436.480 & 351.000 & 429.016 & 349.280 & 426.913 \\
\hline Energia/t papel & $\mathbf{4 , 6 8}$ & $\mathbf{1 1 , 5 1}$ & $\mathbf{4 , 7 1}$ & 11,39 & $\mathbf{4 , 5 9}$ & 4,32 \\
\hline
\end{tabular}

Fonte: Elaboração própria, 2015.

Para o cálculo do consumo de energia por tonelada de papel produzido foi estabelecido uma produção média anual das fábricas constante. Foi uma aproximação subsidiada por informações dadas pelos representantes das fábricas e por dados de produção contidos nos relatórios anuais que são disponibilizados pela Associação Brasileira de Papel e Celulose (BRACELPA) (www.bracelpa.org.br).

Observa-se que a quantidade de energia consumida para cada tonelada de papel produzida nas duas fábricas, foi reduzida no período analisado. A fábrica de Luiz Antonio já apresentava em 2011, um valor considerado positivo de 4,68 Gj/t, enquanto que a fábrica de Mogi Guaçu apresentava um valor de $11,51 \mathrm{Gj} / \mathrm{t}$, que era duas vezes maior que o valor apresentado pela fábrica de Luiz Antônio.

No decorrer do período a fábrica de Luiz Antonio manteve a tendência de queda no indicador analisado e apresentou uma redução total de 1,92 \% no índice, ou seja, a produção de papel foi cada vez menos intensiva em energia durante o período analisado. Tal fato pode ser relacionado com a aplicação da ME na empresa.

Já a fábrica de Mogi Guaçu depois de um início de período preocupante com taxas de consumo de energia por tonelada de papel produzido muito altas, baixou significativamente o valor desse indicador no final do período, em 2013, para um patamar 
considerado aceitável e inclusive mais baixo que o valor apresentado pela fábrica de Luiz Antonio. A redução foi de $62,46 \%$ e a justificativa é a mesma já comentada sobre a construção da caldeira movida à biomassa. O Quadro abaixo apresenta o indicador intensidade de energia elétrica para as fábricas do grupo IP.

Quadro 4.25 Intensidade energética (kWh/t)

\begin{tabular}{|c|c|c|c|}
\hline Fábrica & $\mathbf{2 0 1 1}$ & $\mathbf{2 0 1 2}$ & $\mathbf{2 0 1 3}$ \\
\hline Luiz Antonio & 3,13 & 3,05 & 2,92 \\
\hline Mogi Guaçu & 13,07 & 12,87 & 6,13 \\
\hline
\end{tabular}

Fonte: Relatorios de sustentabiloidade (www.internationalpaper.com)

Pode-se concluir que a fábrica de Luiz Antonio é menos intensiva em energia no seu processo produtivo que a fábrica de Mogi Guaçu, o que permite ser concluído que a fábrica de Luiz Antonio é também mais eficiente em termos de energia que a fábrica de Mogi Guaçu no que diz respeito à produção de papel. Dois outros indicadores que podem ser associados com a aplicação da ME na empresa: menor intensidade de energia consumida e maior eficiência do processo.

De acordo com representantes da fábrica de Luiz Antonio, o processo pelo qual a empresa foi submetida para a obtenção do rótulo ambiental europeu contribuiu para que fossem estabelecidas algumas metas de controle de energia que demandaram iniciativas importantes para que a fábrica continuasse apresentando desempenho ambiental favorável, inclusive para a renovação do rótulo ambiental europeu que ocorreu em 2014. O Quadro a seguir apresenta as principais iniciativas adotadas pelo Grupo IP.

Quadro 4.26 Iniciativas do grupo IP para redução no consumo de energia

\begin{tabular}{|l|c|}
\hline \multicolumn{1}{|c|}{ Iniciativas } & Total de energia economizada (GJ/ano) \\
\hline $\begin{array}{l}\text { Redução de 5 ton/h no consumo de vapor em } \\
\text { máquina de papel de Luiz Antônio }\end{array}$ & $109.746 \mathrm{GJ} / \mathrm{ano}$ \\
\hline $\begin{array}{l}\text { Redução de consumo de óleo em 1.122 ton no forno } \\
\text { de cal de Luiz Antônio }\end{array}$ & $44.555 \mathrm{GJ} / \mathrm{ano}$ \\
\hline $\begin{array}{l}\text { Redução de 8,5ton/h no consumo de vapor na } \\
\text { unidade de Mogi Guaçu }\end{array}$ & $186.568 \mathrm{GJ} / \mathrm{ano}$ \\
\hline $\begin{array}{l}\text { A unidade de Manaus (embalagens) investiu na troca } \\
\text { de equipamentos de ar-condicionado de alto consumo } \\
\text { de energia, o que contribuia com picos de queda de } \\
\text { energia. }\end{array}$ & $354.600 \mathrm{KWh}$ \\
\hline $\begin{array}{l}\text { Na unidade de Rio verde (embalagens), foi realizada } \\
\text { revisâo no sistema de capacitores. }\end{array}$ & $2.371,36 \mathrm{KWh}$ \\
\hline
\end{tabular}

Fonte: Relatorios de sustentabilidade (www.internationalpaper.com) 
Essas iniciativas também foram absorvidas pelas outras unidades do Grupo International Paper do Brasil e proporcionaram economia considerável no consumo de energia nessas unidades.

Importante notar que as iniciativas na fábrica de Luiz Antônio proporcionaram um consumo de energia da ordem de 154.301Gj/ano relacionadas com a redução no consumo de vapor da máquina de papel e uma redução de 1.122 toneladas de óleo combustível no forno dde cal. Ressalta-se que a redução no uso de recursos é uma consequência da aplicação da ME e da rotulagem ambiental na fábrica.

O Quadro 4.27 mostra o consumo de energia de duas fábricas pertencentes a outro grupo do setor de papel e celulose.

Quadro 4.27 Consumo de energia das fábricas do grupo Suzano em (GJ)

\begin{tabular}{|c|c|c|c|c|c|c|c|}
\hline Tipo & R/NR & & & & & & \\
\hline Escopo Fabril & & Limeira & Suzano & Limeira & Suzano & Limeira & Suzano \\
\hline Gá natural & $R$ & 2.198 .712 & 4.704 .325 & 2.235 .758 & 5.230 .629 & 2.438 .901 & 2.842 .467 \\
\hline Licor preto & $R$ & 10.973 .681 & 3.302 .364 & 10.905 .981 & 2.194 .024 & 11.459 .795 & 9.467 .248 \\
\hline Biomassa & $R$ & 138.524 & 3.302 .364 & 166.517 & 2.194 .024 & 1.921 .854 & 550.070 \\
\hline Eletricidade comprada & NR & 1.165 .132 & 1.510 .800 & 1.158 .307 & 1.490 .983 & 1.164 .726 & 1.463 .785 \\
\hline Eletricidade produzida & NR & 981.726 & - & 997.579 & - & 985.734 & \\
\hline Total & & 15.457 .775 & 12.819 .853 & 15.464 .142 & 11.109 .660 & 17.971 .010 & 14.323 .570 \\
\hline
\end{tabular}

Fonte: relatórios de sustentabilidade (www.bracelpa.org.br)

Trata-se das fábricas de Limeira e de Suzano que pertencem ao grupo Suzano Papel e celulose e que não participaram do Projeto de Cooperação para a rotulagem de seus produtos.

O grupo é o maior produtor de celulose do Brasil. Além da celulose as referidas fábricas também produzem o papel para cópia e impressão, mas declinaram do convite para participar do processo de obtenção do Flower do qual participou a fábrica de Luiz Antônio.

Os dados são referentes ao período de 2010 a 2012 e mostram que as quantidades totais de energia consumidas pelas fábricas de Limeira e de Suzano são muito superiores as quantidades consumidas pelas fábricas do grupo IP. Além disso, o consumo de energia aumentou no período analisado. A fábrica de limeira apresentou aumento de 16,25\% enquanto que a fábrica de Suzano apresentou aumento de 11,72\%.

Para efeito de comparação, as fábricas de Luiz Antonio e de Mogi Guaçu, do grupo IP, apresentaram no período de 2011 a 2012, reduções de 2,38\% e 2,74\%, respectivamente, enquanto que no mesmo período, as fábricas de Limeira e Suzano apresentaram aumento de $16,21 \%$ e $28,93 \%$, respectivamente. 
Observa-se que as fábricas do grupo Suzano que não se submeteram ao processo de rotulagem ambiental e que por consequência não adotaram os preceitos da $\mathrm{ME}$, aumentaram o consumo de energia no período analisado.

O Quadro abaixo mostra o consumo de energia por tonelada de papel produzido das fábricas do grupo Suzano no período de 2010 a 2012. Para o cálculo do consumo de energia por tonelada de papel produzido foi estabelecido que a produção média anual das fábricas consideradas fosse constantes. Foi uma aproximação subsidiada por dados de produção contidos nos relatórios anuais que são disponibilizados pela Associação Brasileira de Papel e Celulose (BRACELPA) (www.bracelpa.org.br).

Quadro 4.28 Consumo de energia das fábricas do grupo Suzano em (Gj/t de papel)

\begin{tabular}{|l|c|c|c|c|c|c|}
\hline \multicolumn{1}{|c|}{ Tipo } & \multicolumn{2}{c|}{$\mathbf{2 0 1 0}$} & \multicolumn{2}{c|}{$\mathbf{2 0 1 1}$} & \multicolumn{2}{c|}{$\mathbf{2 0 1 2}$} \\
\hline \multicolumn{1}{|c|}{ Escopo Fabril } & Limeira & Suzano & Limeira & Suzano & Limeira & Suzano \\
\hline Total energia consumida & 15.457 .775 & 12.819 .853 & 15.464 .142 & 11.109 .660 & 17.971 .010 & 14.323 .570 \\
\hline Produção média papel & 310.000 & 460.000 & 307.520 & 456.320 & 306.013 & 460.000 \\
\hline Energia/t papel & $\mathbf{4 9 , 8 6}$ & $\mathbf{2 7 , 8 6}$ & $\mathbf{5 0 , 2 8}$ & 24,34 & $\mathbf{5 8 , 7 2}$ & $\mathbf{3 1 , 9 3}$ \\
\hline
\end{tabular}

Fonte: Elaboração própria, 2015.

No período de 2010 a 2012, a fábrica de Limeira apresentou um aumento do consumo de energia por tonelada de papel produzido de $17,76 \%$, enquanto que a fábrica de Suzano apresentou um aumento de $14,60 \%$.

Para efeito de comparação, no período de 2011 a 2012, as fábricas de Luiz Antônio e Mogi Guaçu, do Grupo IP apresentaram aumento de 0,64\% e 1,04\% respectivamente, para esse mesmo indicador. A primeira variou a relação energia consumida/tonelada produzida de 4,68 em 2011 para 4,71 em 2012, enquanto que a segunda variou de 11,51 para 11,39. No mesmo período, as fábricas de Limeira e de Suzano, do grupo Suzano, apresentaram aumento de $16,78 \%$ e $31,18 \%$ respectivamente. A relação energia consumida/ tonelada produzida variou de 50,28 para 58,72 para a fábrica de Limeira e de 24,34 para 31, 93 para a fábrica de Suzano.

As diferenças ficam mais significativas quando se analisa os valores absolutos para esse indicador. Para efeito de comparação em 2012 a fábrica de Luiz Antônio consumiu $4,71 \mathrm{Gj}$ de energia para cada tonelada de papel propduzido enquanto que a fábrica de Limeira consumiu 58,72 Gj de energia para cada tonelada de papel produzido. O consumo de energia da fábrica de limeira foi mais de12 vezes maior que o consumo de energia da fábrica de Luiz Antônio para produzir a mesma quantidade de papel.

Os melhores resultados apresentados pelas empresas do grupo IP, podem estar relacionados com a influência do processo de obtenção do rotulo ambiental europeu. No 
caso da fábrica de Luiz Antônio o processo de preparação teve início em 2009, enquanto que a fábrica de Mogi Guaçu encontra-se no período de preparação.

É possível concluir que a rotulagem ambiental, na condição de instrumento de promoção da ME, melhora o desempenho ambiental da empresa, notadamente, no que diz respeito ao indicador de consumo de energia.

\subsubsection{Captação de água}

Outro indicador analisado está relacionado com a questão da água que se torna um tema cada vez mais relevante para as empresas do setor de papel e celulose do Brasil, uma vez que seus produtos e operações dependem diretamente dos recursos hídricos. Ciente disso, as empresas do setor vem trabalhando constantemente nas formas de redução do uso de água.

De acordo com representantes do grupo IP, mesmo não existindo um cenário definido sobre o possível futuro da cobrança da água, o assunto já é considerado estratégico pela International Paper, que busca abordá-lo de forma preventiva, indicando o seu comprometimento com as premissas da ME.

Todas as fábricas do grupo IP possuem certificações ISO, que a cada ano exigem o cumprimento das metas estabelecidas e definição de novos objetivos, inclusive em relação ao consumo de água. A água usada pelas fábricas analisadas é majoritariamente de superfície, captada do Rio Mogi Guaçu que não é considerado um rio sensível e não se encontra em áreas protegidas. O grupo IP não usa água de áreas úmidas listadas pela Convenção de Ramsar e nem afeta povos indígenas ou comunidades locais na captação de água para o processo produtivo. O Quadro 4.29 mostra os dados referentes à água captada, reciclada e reutilizada pelas fábricas de Luiz Antônio e Mogi Guaçu.

Quadro 4.29 Volume total de água captada, reciclada e reutilizada $\left(\mathrm{m}^{3} / \mathrm{ano}\right)$.

\begin{tabular}{|l|c|c|c|c|c|c|}
\hline \multicolumn{1}{|c|}{ Tipo } & \multicolumn{2}{c|}{2011} & \multicolumn{2}{c|}{2012} & \multicolumn{2}{c|}{2013} \\
\hline \multicolumn{1}{|c|}{ Escopo fabril } & LA & MOGI & LA & MOGI & LA & MOGI \\
\hline $\begin{array}{l}\text { Volume Total de água } \\
\text { captada }\end{array}$ & 22.531 .435 & 23.308 .856 & 23.498 .932 & 24.439 .075 & 23.910 .973 & 23.596 .734 \\
\hline $\begin{array}{l}\text { Volume total de água } \\
\text { reciclada e reutilizada }\end{array}$ & 6.759 .430 & 6.992 .657 & 7.049 .680 & 7.331 .723 & 7.173 .292 & 7.079 .020 \\
\hline $\begin{array}{l}\text { Capitação Total/ton papel } \\
\text { produzido }\end{array}$ & 63,09 & 53,4 & 66,94 & 56,96 & 68,45 & 55,27 \\
\hline $\begin{array}{l}\text { Água reutilizada/ton papel } \\
\text { produzido }\end{array}$ & 18,92 & 16,02 & 20,08 & 17,08 & 20,53 & $\mathbf{1 6 , 5 8}$ \\
\hline $\begin{array}{l}\text { Água reutilizada/volume } \\
\text { captado }\end{array}$ & $30 \%$ & $30 \%$ & $30 \%$ & $30 \%$ & $30 \%$ & $30 \%$ \\
\hline
\end{tabular}

Fonte: Relatorios de sustentabilidade (www.internationalpaper.com) 
Da observação do Quadro pode-se concluir que o volume captado pela fábrica de Luiz Antonio aumentou no período analisado em 6,12\% enquanto que na fábrica de Mogi Guaçu o aumento foi de 1,23\%. Nas duas fábricas os volumes totais de água reciclada e reutilizada aumentaram também na mesma proporção da água captada de forma que a relação total de água reutilizada por volume captado permanece sempre em 30\%.

O Programa de Rotulagem Ambiental da União Européia no critério relativo à agua, não prioriza a quantidade total consumida pela empresa, mas ressalta a necessidade da água reutilizada ou reciclada.

No caso da fábrica de Luiz Antônio, levando-se em consideração o período analizado, encontra-se um aumento de $8,50 \%$ para a relação água reutilizada / tonelada produzida, enquanto que para a fábrica de Mogi Guaçu, o aumento da mesma relação é de $3,49 \%$.

Importa afirmar que é necessário que as empresas desenvolvam processos produtivos menos intensivos no consumo de água e qualquer aumento nesse consumo deve ser considerado um problema ambiental para ser resolvido. Dessa forma, entendo que o Flower deveria considerar como critério, não só o tratamento da água que é utilizada pela fábrica em seu processo produtivo, mas também o consumo total de água que deve diminuir para que os novos produtos sejam menos intensivos nesse recurso natural tão precioso.

É importante notar também que o volume total de água captado pelas fábricas não é somente utilizado para a fabricação de papel para cópia e impressão.

No que diz respeito ao indicador captação da água para as fábricas do grupo Suzano, não estavam disponíveis os dados referentes às quantidades recicladas ou reutilizadas por fábricas, apenas para o grupo na sua totalidade. Para efeito de comparação, o Quadro abaixo apresenta os valores relacionados com o volume total captado para as fábricas de Limeira e de Suzano, no período de 201012012.

Quadro 4.30 Volume total de água captada por tonelada de papel produzido ( $\left.\mathrm{m}^{3} / \mathrm{ano}\right)$.

\begin{tabular}{|c|c|c|c|c|c|c|}
\hline \multicolumn{1}{|c|}{ Tipo } & \multicolumn{2}{c|}{2010} & \multicolumn{2}{c|}{2011} & \multicolumn{2}{c|}{2012} \\
\hline Escopo fabril & Limeira & Suzano & Limeira & Suzano & Limeira & Suzano \\
\hline Volume Total de água capitada & 26.532 .722 & 24.342 .846 & 26.699 .447 & 24.761 .564 & 26.823 .988 & 24.098 .760 \\
\hline Produção média de papel/ano & 310.000 & 460.000 & 307.520 & 456.320 & 306.013 & 448.516 \\
\hline Volume total/papel produzido & 85,58 & 52,91 & 86,82 & 54,26 & 87,65 & 53,72 \\
\hline
\end{tabular}

Fonte: relatórios de sustentabilidade (www.bracelpa.org.br)

Do Quadro acima se observa que os volumes totais captados pelas empresas do grupo Suzano são maiores que os volumes captados pelas empresas do grupo IP. Isso 
pode significar que essas empresas consomem mais água em seus processos produtivos, que as empresas do grupo IP.

Quando comparamos as empresas dos dois grupos observamos que a maior relação volume total captado de água/ tonelada de papel produzido foi apresentada pela fábrica de Limeira, em 2012, com 87,65, enquanto que a fábrica de Suzano apresentou o menor valor no ano de 2010 de 52,91. As fábricas do grupo IP apresentaram valores que variaram de 53,40 para Mogi, em 2011 e 68,45 para Luiz Antônio, em 2013.

Observa-se também que no ano de 2012, a fábrica de Luiz Antonio, do grupo IP e a fábrica de Limeira, do grupo Suzano, apresentaram produções similares com 351.000 toneladas e 306.013 toneladas, respectivamente, porém a fábrica de Limeira apresentou no ano de 2012, um consumo de água por tonelada de papel produzida da ordem de 30,93\% maior que a fábrica de Luiz Antonio.

\subsubsection{Emissões de gases de efeito estufa e outros gases}

O controle das emissões de gases de efeito estufa é tema que se torna cada vez mais relevante, considerando, principalmente, o futuro das legislações em relação a essas emissões. As atividades industriais são emissoras de GEE (gases de efeito estufa) e as florestas captam alguns desses gases.

As principais emissões atmosféricas do grupo IP são de dióxido de carbono $\left(\mathrm{CO}_{2}\right)$, materiais particulados (poeira e cinzas), óxidos de enxofre, enxofre não oxidado e óxidos de nitrogênio. A emissão de gases de enxofre não oxidados, que é caracterizada por forte, é monitorada continuamente e em tempo real. Os demais gases são monitorados regularmente e acompanhados pelos órgãos ambientais estaduais. $O$ aspecto é objeto de auditoria da certificação ISO 14001 e conta com planos de melhorias contínuas.

As emissões de gases de efeito estufa (GEE) do grupo IP são calculadas a partir do método NCASI for The Climate Change Working Group of the International Council of Forest and Paper Associations (ICFPA). O Quadro abaixo apresenta as quantidades emitidas de $\mathrm{CO}_{2}$, de forma direta e indireta, no período de 2009 a 2013, pelas fábricas do grupo IP.

Quadro 4.31 Emissões Diretas e indiretas de Gases de efeito estufa (Ton $\mathrm{CO}_{2 \mathrm{eq}}$ )

\begin{tabular}{|l|c|c|c|c|c|c|c|c|c|c|}
\hline Fábrica & \multicolumn{2}{|c|}{2009} & \multicolumn{2}{c|}{2010} & \multicolumn{2}{c|}{2011} & \multicolumn{2}{c|}{2012} & \multicolumn{2}{c|}{2013} \\
\hline & Direta & Indireta & Direta & Indireta & Direta & Indireta & Direta & Indireta & Direta & Indireta \\
\hline LA & $\mathbf{5 9 . 0 5 9}$ & 8.128 & $\mathbf{5 0 . 5 3 9}$ & 8.313 & $\mathbf{5 3 . 4 8 9}$ & 8.028 & $\mathbf{4 6 . 1 3 8}$ & 8.330 & $\mathbf{4 7 . 2 1 5}$ & 8.151 \\
\hline MOGI & $\mathbf{2 8 5 . 0 4 0}$ & 8.460 & 235.159 & 8.610 & 222.418 & 9.839 & 204.202 & 10.015 & $\mathbf{4 7 . 1 0 8}$ & 9.159 \\
\hline
\end{tabular}

Fonte: Relatorios de sustentabiloidade (www.internationalpaper.com) 
Observa-se que até ao ano de 2012, os valores das emissões diretas de gases de efeito estufa da fábrica de Luiz Antonio eram aproximadamente 4 vezes menor que os valores apresentados pela fábrica de Mogi Guaçu. Fato que já mostrava os resultados obtidos pelas mudanças realizadas no processo produtivo para se adequar às exigências do Programa de Rotulagem Ambiental da União Européia.

No período de 2009 até 2013 ocorreu uma redução da ordem de 20,05\% nas emissões diretas de gases de efeito estufa na fábrica de Luiz Antonio. Aproveitando-se dos resultados positivos apresentados pela fábrica de Luiz Antonio, os representnates do grupo IP decidiram submeter a fábrica de Mogi Guacu ao processo de obtenção do Flower e para isso substituíram, em 2012, uma caldeira movida à gás por uma caldeira movida à biomassa com investimentos da ordem de U\$ 90 milhões.

Pelos resultados apresentados nao Quadro 4.29, a caldeira de biomassa foi a grande responsável pela redução significativa referente às emissões diretas de gases de efeito estufa, da ordem de $73,96 \%$, que ocorreu no ano de 2013 , quando entrou em funcionamento na fábrica de Mogi Guacu. Os valores absolutos passaram de 204.202 Ton $\mathrm{CO}_{2 \text { eq }}$ para 47.108 Ton $\mathrm{CO}_{2 \text { eq }}$.

Com esse desempenho, existe a possibilidade de a fábrica de Mogi Guaçu ser aprovada pelo Programa de Rotulagem Ambiental da União Européia. O Objetivo do grupo IP é alcançar as mesmas certificações Flower e Colibri para as duas fábricas para que ambas possam exportar o papel para cópia e impressão para os nichos de mercado de papel rotulado europeus e aumentar a participação do grupo IP nesse mercado, além de propiciar o uso do rótulo ambiental nacional (Colibri), no mercado doméstico.

Se os valores apresentados pelas empresas analisadas em 2009 e referentes às emissões totais de GEE tivessem sido os mesmos até 2013, os valores totais emitidos seriam de 335.935 Ton $\mathrm{CO}_{2 \text { eq }}$ para a fábrica de Luiz Antônio e de 1.467 .500 Ton $\mathrm{CO}_{2 \text { eq }}$ para a fábrica de Mogi Guacu. No entando com as mudanças realizadas em ambos os processos produtivos os valores totais emitidos em 2013 foram de 116.883 Ton $\mathrm{CO}_{2 \text { eq }}$ e 776.666 Ton $\mathrm{CO}_{2 \text { eq }}$ respectivamente, o que representou uma economia de 219.052 Ton $\mathrm{CO}_{2 \text { eq }}$ para a fábrica de Luiz Antônio e 690.834 Ton $\mathrm{CO}_{2 \text { eq }}$ para a fábrica de Mogi Guacu.

Os resultados conseguidos com a redução de emissões de GEE pelas empresas do grupo IP, corroboram o fato de que a adoção da ME e a utilização da rotulagem ambiental contribuem efetivamente para a mitigação das mudanças climáticas.

No Quadro a seguir, são apresentados os valores referentes às emissões totais de gases de efeito estufa/tonelada de papel produzido. O período avaliado é de 2009 a 2013. 
Quadro 4.32 Emissões totais de gases de efeito estufa, por tonelda de papel produzido (Ton $\left.\mathrm{CO}_{2 \text { eq }} / \mathrm{t}\right)$

\begin{tabular}{|l|c|c|c|c|c|c|c|c|c|c|}
\hline Fábrica & \multicolumn{2}{|c|}{2009} & \multicolumn{2}{c|}{$\mathbf{2 0 1 0}$} & \multicolumn{2}{c|}{$\mathbf{2 0 1 1}$} & \multicolumn{2}{c|}{$\mathbf{2 0 1 2}$} & \multicolumn{2}{c|}{2013} \\
\hline & $\mathrm{ET}$ & $\mathrm{ET} / \mathrm{t}$ & $\mathrm{ET}$ & $\mathrm{ET} / \mathrm{t}$ & $\mathrm{ET}$ & $\mathrm{ET} / \mathrm{t}$ & $\mathrm{ET}$ & $\mathrm{ET} / \mathrm{t}$ & $\mathrm{ET}$ & $\mathrm{ET} / \mathrm{t}$ \\
\hline $\begin{array}{l}\text { Luiz } \\
\text { Antonio }\end{array}$ & 67.187 & $\mathbf{0 , 1 9}$ & 58.852 & $\mathbf{0 , 1 6 3}$ & 61.517 & $\mathbf{0 , 1 7 2}$ & 54.468 & $\mathbf{0 , 1 5 5}$ & 55.366 & $\mathbf{0 , 1 5 8}$ \\
\hline $\begin{array}{l}\text { Mogi } \\
\text { Guaçu }\end{array}$ & 293.500 & 0,7 & 243.769 & 0,554 & 232.257 & 0,532 & 214.217 & 0,499 & $\mathbf{5 7 . 1 2 3}$ & $\mathbf{0 , 1 3 3}$ \\
\hline
\end{tabular}

Fonte: Elaboração própria, 2015.

Onde: $\mathrm{ET}=$ Emissões Totais (Direta + Indireta)

ET/T Emissões Totais por tonelada

Os dados dispostos no Quadro mostram que as emissões totais de gases de efeito estufa da fábrica de Luiz Antonio, no período de 2009 a 2013 foram reduzidas em 17,74\%. Já a fábrica de Mogi Guaçu apresentou redução de 80,65\% no mesmo período.

Nota-se que até 2012 os patamares de emissões das fábricas consideradas eram bastante diferentes. Enquanto a fábrica de Luiz Antonio, já rotulada pelo Flower apresentava um total de 54.468 Ton $\mathrm{CO}_{2 e q}$, a fábrica de Mogi Guaçu apresentava um total de 214.217 Ton $\mathrm{CO}_{2 \text { eq, }}$ um valor quase 5 vezes maior que o da primeira.

De acordo com representantes do grupo IP, a unidade de Mogi Guaçu reduziu em mais de 150 mil toneladas equivalentes de $\mathrm{CO}_{2}$ com a instalação da caldeira de biomassa, além de ter diminuído o consumo de vapor na recuperação e utilidades o que proporcionou redução de 270 Ton $\mathrm{CO}_{\text {2eq. }}$

A unidade de Luiz Antônio, por sua vez, apresentou redução de 160 Ton $\mathrm{CO}_{2 \text { eq }}$ com a redução de consumo de vapor em máquina de papel e de 3.500 Ton $\mathrm{CO}_{2 \text { eq }}$ com a redução do consumo de óleo combustível. Totas alterações foram realizadas em função das demandas necessárias para atender aos requisitos do programa de rotulagem ambiental da União Européia.

Os valores referentes à relação emissões totais de GEE/tonelada de papel produzido mostram que as duas fábricas do grupo IP "esverdearam" seus processos produtivos atingindo taxas significativas de eficiência ecológica. No período analisado a fábrica de Luiz Antônio mostrou-se 17,74\% mais eficiente enquanto que a fábrica de Mogi Guacu aumentou sua eficiência em $80,65 \%$.

No quadro a seguir são apresentados os valores referentes às emissões de outros gases pelas fábricas analisadas, no período de 2008 a 2013. 
Quadro 4.33 Emissões de $\mathrm{NO}_{\mathrm{x}}$, $\mathrm{SO}_{\mathrm{x}}$ e outros gases (Toneladas).

\begin{tabular}{|l|c|c|c|c|c|c|c|c|c|c|}
\hline Tipo & \multicolumn{2}{|c|}{2008} & \multicolumn{2}{c|}{2009} & \multicolumn{2}{c|}{2010} & \multicolumn{2}{c|}{2011} & \multicolumn{2}{c|}{2012} \\
\hline & LA & MOGI & LA & MOGI & LA & MOGI & LA & MOGI & LA & MOGI \\
\hline NOx & NA & 1.395 & 750 & 1.462 & 888 & 1.453 & 1.453 & 1.048 & 1.380 & 1390 \\
\hline SO $x$ & 341 & 262 & 121 & 567 & 357 & 572 & 327 & 1.921 & 96 & 834 \\
\hline MP & 3.433 & 983 & 2.703 & 673 & 1.370 & 677 & 1.013 & 1.002 & 1.051 & 758 \\
\hline TRS & 0 & 118 & 46 & 119 & 35 & 119 & 23 & 56 & 9 & 90 \\
\hline Total & $\mathbf{3 . 7 7 4}$ & 2.758 & $\mathbf{3 . 6 2 0}$ & 2.821 & $\mathbf{2 . 6 5 0}$ & 2821 & $\mathbf{2 . 8 1 6}$ & 4.027 & $\mathbf{2 . 5 3 6}$ & 3.072 \\
\hline
\end{tabular}

Fonte: Relatorios de sustentabiloidade (www.internationalpaper.com)

Onde:

$\mathrm{NO}_{\mathrm{x}}$ : óxidos de Nitrogênio, calculados com base em amostragens periódicas e expressos em $\mathrm{NO}_{2}$. $\mathrm{SO}_{\mathrm{x}}$ : óxidos de Enxofre, calculados com base em amostragens periódicas e expressos em $\mathrm{SO}_{2}$. MP: Material Particulado, calculado com base em amostragens periódicas.

TRS: Compostos Reduzidos de Enxofre, calculados com base em amostragens periódicas e expressos em $\mathrm{SO}_{2}$.

Pode-se observar que no período analisado as emissões atmosféricas totais da fábrica de Luiz Antonio diminuíram em 13,67\% enquanto que no mesmo período as emissões totais da fábrica de Mogi Guaçu aumentaram em 16,24\%. Foram registrados desempenhos positivos da fabrica de Luiz Antonio em todas as emissões avaliadas, com exceção das emissões dos óxidos de nitrogênio que aumentaram 73\% no período de 2009 a 2013.

A fábrica de Luiz Antonio apresentou redução significativa da emissão de materiais particulados que passaram de 3.433 ton em 2008 para 744 ton em 2013, uma redução de $78,32 \%$.

Quadro 4.34 Emissões de $\mathrm{NO}_{\mathrm{x}}, \mathrm{SO}_{\mathrm{x}}$ e outros gases /tonelada de papel.

\begin{tabular}{|l|c|c|c|c|c|c|c|c|}
\hline & \multicolumn{2}{|c|}{2009} & \multicolumn{2}{c|}{2010} & \multicolumn{2}{c|}{2011} & \multicolumn{2}{c|}{2012} \\
\hline & LA & MOGI & LA & MOGI & LA & MOGI & LA & MOGI \\
\hline ET & 3.620 & 2.821 & 2.650 & 2.821 & 2.816 & 4.027 & 2.536 & 3.072 \\
\hline PP & 342.800 & 419.000 & 360.000 & 440.000 & 357.120 & 436.480 & 351.000 & 429.016 \\
\hline ET/P & 10,56 & 6,73 & 7,36 & 6,41 & 7,88 & 9,22 & 7,22 & 7,16 \\
\hline
\end{tabular}

Fonte: 0 autor

Onde:

$\mathrm{ET}=$ Emissões Totais

$\mathrm{PP}=$ Produção de Papel (toneladas)

$\mathrm{ET} / \mathrm{P}=$ Emissões totais por tonelada de papel $(\mathrm{X} 1000)$

Os dados acima nos mostram que as emissões atmosféricas por tonelada de papel produzido, da fábrica de Luiz Antonio, no período de 2009 a 2013 apresentou redução de 41,57\%, enquanto que a fábrica de Mogi Guaçu apresentou um aumento de $10,26 \%$. As mudanças adotadas pela fábrica de Luiz Antônio para a obtenção do Flower contribuíram 
para que tivesse um desempenho ambiental melhor que o da fábrica de Mogi Guacu que ainda está em processo de prepapração para se submeter ao Flower.

Para efeito de comparação, na tabela abaixo estão os valores das emissões atmosféricas da fábrica de Limeira de da fábrica de Suzano, do grupo Suzano Papel e Celulose, no período de 2009 a 2012.

Quadro 4.35 Emissões de $\mathrm{NO}_{\mathrm{x}}, \mathrm{SO}_{\mathrm{x}}$ e outros gases (Toneladas).

\begin{tabular}{|l|l|l|l|l|l|l|l|l|}
\hline Emissão & \multicolumn{2}{|c|}{2009} & \multicolumn{2}{c|}{2010} & \multicolumn{2}{c|}{2011} & \multicolumn{2}{c|}{2012} \\
\hline & Limeira & Suzano & Limeira & Suzano & Limeira & Suzano & Limeira & Suzano \\
\hline NOX & $1.134,87$ & $1.980,55$ & 749,08 & $2.070,88$ & $1.018,37$ & $1.189,06$ & $1.188,76$ & $1.109,44$ \\
\hline SOX & $1.239,61$ & 159,62 & 932,77 & 161,46 & 393,88 & 121,76 & 545,75 & 109 \\
\hline MP & 736,94 & 236,87 & 418,67 & 256,89 & 258,14 & 403,34 & 527,8 & 257,92 \\
\hline TRS & 11,38 & 2,59 & 8,69 & 1,75 & 10,85 & 2,13 & 7,95 & 2,6 \\
\hline Total & $\mathbf{3 . 1 1 2 , 8 0}$ & $2.379,63$ & $\mathbf{2 . 1 0 9 , 2 1}$ & $2.490,98$ & $\mathbf{1 . 6 8 1 , 2 4}$ & $1.716,29$ & $\mathbf{2 . 2 7 0 , 2 6}$ & $1.478,96$ \\
\hline
\end{tabular}

Fonte: relatórios de sustentabilidade (www.bracelpa.org.br)

Observam-se valores totais similares comos valores apresentados pelas empresas do grupo IP. Todas mostrando diminuição total de emissões no período analisado.

Ressalta-se que não foi possível obter os dados das emissões diretas e indiretas dos gases de efeito estuda para as fábricas do grupo Suzano Papel e Celulose, o que impossibilitou a comparação com os dados das fábricas do grupo IP.

\subsubsection{Gestão de efluentes de resíduos}

A gestão de efluentes e de resíduos é um dos temas vinculados às metas globais de sustentabilidade do grupo IP. A destinação adequada está diretamente relacionada com a redução desses resíduos que seguem para aterros sanitários e compostagem e com a geração de energia.

Os principais resíduos gerados pelas operações do grupo IP América Latina são provenientes dos processos industriais, incluindo os lodos oriundos dos sistemas de tratamento de efluentes líquidos, as cinzas da queima de biomassa, além das cascas de eucalipto provenientes do processo de produção de celulose e papel. A empresa possui indicadores específicos sobre a geração e a destinação desse tipo de resíduo e adota uma série de medidas preventivas, que são características das empresas que adotam as premissas da ME.

No Brasil, apenas os materiais inertes são destinados aos aterros. Existe um trabalho em conjunto com a CETESB para direcionar os resíduos, que hoje são considerados subprodutos e são utilizados para compostagem, processo em que os resíduos originados 
durante a fabricação de celulose - após o processo de tratamento - são aplicados nos solos das florestas de eucalipto da própria empresa como adubo. A ideia futura é utilizar os resíduos para outros tipos de lavoura.

Existem metas para redução dos efluentes líquidos, relacionadas principalmente com as metas de qualidade, bem como acompanhamento dos DBOs (demanda bioquímica de oxigênio) das fábricas. Os resíduos não industriais, originados em escritórios e restaurantes, são administrados por prestadores de serviços sob a supervisão da empresa.

Profissionais das áreas industriais e administrativas são conscientizados e colaboram no processo da coleta seletiva, fazendo a separação dos resíduos no momento do descarte. Para reduzir possíveis riscos no manejo, as empresas que recebem os materiais recicláveis devem apresentar certificações e licenças ambientais, além de passar por auditorias realizadas pelo grupo IP América Latina a cada seis meses, para averiguação da destinação dos materiais, bem como suas práticas e a situação perante órgãos ambientais.

No Quadro 4.36, a se4guir, é apresentado o volume de descartes na água das demandas químicas (DQO) e bioquímicas de Oxigênio (DBO) e o total dessas demandas por tonelada de papel produzido para as empresas de Luiz Antonio e Mogi Guaçu no período de 2009 a 2013.

Quadro 4.36 Descartes de DQO, DBO e descartes totais por tonelada de papel produzido em (t).

\begin{tabular}{|l|c|c|c|c|c|c|c|c|}
\hline Tipo & \multicolumn{2}{|c|}{2009} & \multicolumn{2}{c|}{2010} & \multicolumn{2}{c|}{2011} & \multicolumn{2}{c|}{2012} \\
\hline & LA & MOGI & LA & MOGI & LA & MOGI & LA & MOGI \\
\hline DQO & 3.164 & 2.424 & 4.040 & 2.357 & 3.731 & 3.382 & 2.997 & 3.463 \\
\hline DBO & 225 & 84 & 338 & 54 & 353 & 97 & 231 & 96 \\
\hline DT & 3.389 & 2.508 & 4.378 & 2.411 & 4.084 & 3.479 & 3.228 & 3.559 \\
\hline P.P & $\mathbf{3 4 2 . 8 0 0}$ & $\mathbf{4 1 9 . 0 0 0}$ & $\mathbf{3 6 0 . 0 0 0}$ & $\mathbf{4 4 0 . 0 0 0}$ & $\mathbf{3 5 7 . 1 2 0}$ & $\mathbf{4 3 6 . 4 8 0}$ & $\mathbf{3 5 1 . 0 0 0}$ & $\mathbf{4 2 9 . 0 1 6}$ \\
\hline DT/P & $\mathbf{9 , 8 8}$ & 5,98 & $\mathbf{1 2 , 1 6}$ & 5,48 & $\mathbf{1 1 , 4 3}$ & 7,97 & $\mathbf{9 , 1 9}$ & 8,29 \\
\hline
\end{tabular}

Fonte: Elaboração própria, 2015.

Onde:

P.P = Produção de Papel

$\mathrm{DT} / \mathrm{P}=$ Descartes Totais $(\mathrm{DQO}+\mathrm{DBO})$ por tonelada de papel produzido

Observando os dados contidos na tabela percebe-se que a relação entre os descartes totais e a tonelada de papel produzido da fábrica de Luiz Antonio aumentou $13,46 \%$ no período analisado, enquanto que o mesmo indicador da fábrica de Mogi Guaçu aumentou 44,81\%, no mesmo período.

Quando são considerados os valores a partir de 2011, quando a fábrica de Luiz Antonio adquiriu o rótulo ambiental da União Européia, percebe-se uma diminuição no 
indicador analisado de 1,92\% demonstrando melhora no desempenho ambiental. No mesmo período a fábrica de Mogi Guaçu aumentou este indicador em 8,65\%.

Quanto aos valores de descartes totais também é percebido uma diminuição de $4,1 \%$, apresentado pela fábrica de Luiz Antonio, a partir de 2011. No mesmo período a fábrica de Mogi Guaçu apresentou aumento de 53\% na quantidade de eflentes totais.

Para efeito de comparação apresentam-se no Quadro 4.35, os valores de DQO, DBO e a relação descarte total por tonelada de papel produzida, para as fábricas do grupo Suzano Papel e Celulose.

Ressalta-se que os períodos analisados são diferentes. Para o período de 2009 a 2012 a fábrica de Limeira apresentou uma pequena diminuição de 0,6\% na relação de descartes totais por tonelada de papel produzida enquanto que a fábrica de Suzano apresentou pequeno aumento de 1,09\%.

Quando comparamos com os valores das empresas do grupo IP percebemos que no período de 2009 a 2012, a fábrica de Luiz Antonio apresentou uma diminuição de 4,67\% enquanto que a fábrica de Mogi Guaçu apresentou aumento de 38,59\% na relação quantidade total de efluentes por tonelada de papel produzido.

Quadro 4.37 Descartes de DQO, DBO e descartes totais por tonelada de papel produzido em (t).

\begin{tabular}{|l|c|c|c|c|c|c|c|c|}
\hline Tipo & \multicolumn{2}{|c|}{2009} & \multicolumn{2}{c|}{2010} & \multicolumn{2}{c|}{2011} & \multicolumn{2}{c|}{2012} \\
\hline & Limeira & Suzano & Limeira & Suzano & Limeira & Suzano & Limeira & Suzano \\
\hline DQO & 5.742 & 4.377 & 6.138 & 4.021 & 5.011 & 4.204 & 5.728 & 4.450 \\
\hline DBO & 243 & 649 & 259 & 640 & 225 & 643 & 214 & 629 \\
\hline DT & 5.985 & 5.026 & 6.397 & 4.661 & 5.236 & 4.847 & 5.942 & 5.079 \\
\hline P P & $\mathbf{2 9 5 . 2 0 0}$ & $\mathbf{4 3 8 . 1 0 0}$ & $\mathbf{3 1 0 . 0 0 0}$ & $\mathbf{4 6 0 . 0 0 0}$ & $\mathbf{3 0 7 . 5 2 0}$ & $\mathbf{4 5 6 . 3 2 0}$ & $\mathbf{3 0 6 . 3 1 3}$ & $\mathbf{4 4 8 . 5 1 6}$ \\
\hline D T/P & $\mathbf{2 0 , 2 7}$ & $\mathbf{1 1 , 4 7}$ & $\mathbf{2 0 , 6 3}$ & $\mathbf{1 0 , 1 3}$ & $\mathbf{1 7 , 0 2}$ & $\mathbf{1 0 , 6 2}$ & $\mathbf{1 9 , 4 1}$ & $\mathbf{1 1 , 3 2}$ \\
\hline
\end{tabular}

Fonte: Elaboração própria, 2015.

Onde:

P.P = Produção de Papel

$\mathrm{DT} / \mathrm{P}=($ Descartes Totais $(\mathrm{DQO}+\mathrm{DBO})$ por tonelada de papel produzido $) \times 1000$

A partir de 2011, a fábrica de Suzano apresentou aumento de 6,59\% no indicador analisado, enquanto que a fábrica de Limeira aumentou $14,04 \%$. Neste mesmo período a fábrica de Luiz Antonio diminui e relação quantidade de efluentes totais por tonelada de papel produzido em 1,92\% enquanto a fábrica de Mogi Guaçu aumentou em 8,65\%.

Conclui-se que apenas a fábrica de Luiz Antonio diminuiu a relação quantidade de efluentes por tonelada de papel produzido, a partir de 2011, fato que comprova os benefícios positivos advindos da adoção da ME e da rotulagem ambiental, pela fábrica. 
Depreendemos também das tabelas acima que em 2012 as fábricas de Suzano e de Limeira produziram juntas 11.021 toneladas de efluentes, enquanto que as fábricas de Luiz Antonio e Mogi Guaçu produziram 7.614 toneladas de efluentes, quantidade 30,91\% menor. Pode-se inferir que o desempenho ambiental apresentado pelas empresas do grupo IP é melhor que o desempenho apresentado pelas empresas do grupo Suzano Papel e Celulose.

\subsection{Aspectos econômicos}

Com o objetivo de subsidiar os cálculos econômicos relacionados com a adoção da rotulagem ambiental pela fábrica de Luiz Antônio são apresentadas informações referentes à produção nacional de papel, às quantidades vendidas no Brasil, às quantidades exportadas e às quantidades exportadas por destino. O período compreende os anos de 2009, 2010, 2011, 2012 e 2013, de acordo com a Associação Brasileira de Celulose e Papel (BRACELPA).

De acordo com o Quadro 4.36 observa-se que a produção total de papel no Brasil aumentou $10,60 \%$ em quantidade, enquanto que a produção específica do papel para imprimir e escrever diminui 1,70\%. No ano de 2009 o Brasil produziu 2 milhões 575 mil toneladas de papel para imprimir e escrever e em 2013 produziu 2 milhões 619 mil toneladas.

Quadro 4.38 Produção Brasileria de Papel (1.000 toneladas)

\begin{tabular}{|c|c|c|c|c|c|}
\hline Tipo & $\mathbf{2 0 0 9}$ & $\mathbf{2 0 1 0}$ & $\mathbf{2 0 1 1}$ & $\mathbf{2 0 1 2}$ & $\mathbf{2 0 1 3}$ \\
\hline Embalagem & 4.649 & 4862 & 5.168 & 5.115 & 5.348 \\
\hline Imprimir e Escrever & $\mathbf{2 . 5 7 5}$ & $\mathbf{2 7 0 4}$ & $\mathbf{2 . 6 8 0}$ & $\mathbf{2 . 6 3 4}$ & $\mathbf{2 . 6 2 1}$ \\
\hline Imprensa & 127 & 124 & 129 & 131 & 128 \\
\hline Fins Sanitários & 868 & 905 & 961 & 1.034 & 196 \\
\hline Papel Cartão & 748 & 786 & 733 & 760 & 739 \\
\hline Outros & 461 & 463 & 488 & 507 & 498 \\
\hline Total & $\mathbf{9 4 2 8}$ & $\mathbf{9 8 4 4}$ & $\mathbf{1 0 . 1 5 9}$ & $\mathbf{1 0 . 1 8 2}$ & $\mathbf{1 0 . 4 2 8}$ \\
\hline
\end{tabular}

Fonte: BRACELPA (www.bracelpa.org.br)

Enquanto a produção de papel para imprimir e escrever, no período analisado, aumentou $1,70 \%$,as vendas para o mercado interno do mesmo produto aumentaram $8,66 \%$, de acordo com o Quadro 4.39, a seguir.

Foi registrada também uma tendência de aumento nas vendas totais de papel para o mercado interno que passaram de 5 milhões e 53 mil toneladas, em 2009, para 5 milhões 716 mil toneladas, em 2013, registrando aumento de $13,12 \%$. 
Quadro 4.39 Vendas Domésticas de Papel (1.000 toneladas)

\begin{tabular}{|c|c|c|c|c|c|}
\hline Tipo & $\mathbf{2 0 0 9}$ & $\mathbf{2 0 1 0}$ & $\mathbf{2 0 1 1}$ & $\mathbf{2 0 1 2}$ & $\mathbf{2 0 1 3}$ \\
\hline Embalagem & 1.577 & 1.698 & 1.681 & 1.689 & 1.817 \\
\hline Imprimir e Escrever & $\mathbf{1 . 5 6 9}$ & $\mathbf{1 . 6 1 3}$ & $\mathbf{1 . 6 3 0}$ & $\mathbf{1 . 6 8 8}$ & $\mathbf{1 . 7 0 5}$ \\
\hline Imprensa & 120 & 122 & 121 & 132 & 127 \\
\hline Fins Sanitários & 865 & 916 & 933 & 1.022 & 1.083 \\
\hline Papel Cartão & 499 & 573 & 512 & 530 & 557 \\
\hline Outros & 423 & 385 & 413 & 421 & 427 \\
\hline Total & $\mathbf{5 . 0 5 3}$ & $\mathbf{5 . 0 3 7}$ & $\mathbf{5 . 2 9 0}$ & $\mathbf{5 . 4 8 2}$ & $\mathbf{5 . 7 1 6}$ \\
\hline
\end{tabular}

Fonte: BRACELPA (www.bracelpa.org.br)

Já as exportações totais Brasileiras de papel, no período de 2009 a 2013 e de acordo com o quadro abaixo, diminuíram 7,07\%, enquanto que as quantidades exportadas de papel para imprimir e escrever diminuíram 8,00\% e passaram de 1 milhão de toneladas exportadas, em 2009, para 920 mil toneladas, em 2013. Outros segmentos de papel também apresentaram movimento negativo nas quantidades exportadas, enquanto que 0 seguimento de papel para embalagem registrou aumento de 5,27\%.

Quadro 4.40 Exportações brasileiras de Papel (1.000 toneladas)

\begin{tabular}{|c|c|c|c|c|c|}
\hline Tipo & 2009 & 2010 & 2011 & 2012 & 2013 \\
\hline Embalagem & 588 & 581 & 606 & 504 & 619 \\
\hline Imprimir e Escrever & $\mathbf{1 . 0 0 0}$ & $\mathbf{1 . 0 9 1}$ & $\mathbf{1 . 0 3 4}$ & $\mathbf{9 5 2}$ & $\mathbf{9 2 0}$ \\
\hline Imprensa & 0 & 1 & 2 & 1 & 1 \\
\hline Fins Sanitários & 10 & 12 & 8 & 9 & 11 \\
\hline Papel Cartão & 250 & 213 & 221 & 230 & 182 \\
\hline Outros & 160 & 176 & 181 & 179 & 133 \\
\hline Total & $\mathbf{2 0 0 8}$ & $\mathbf{2 0 7 4}$ & $\mathbf{2 . 0 5 2}$ & $\mathbf{1 . 8 7 5}$ & $\mathbf{1 . 8 6 6}$ \\
\hline
\end{tabular}

Fonte: BRACELPA (www.bracelpa.org.br)

O quadro, a seguir mostra as exportações brasileiras de papel, no período de 2009 a 2013, por destino. Nota-se que os únicos mercados que mostraram retração em relação às vendas nacionais foram a União Européia com uma diminuição de 7,39\% e a África, com uma redução de $23,3 \%$.

Todos os outros mercados apresentaram alta, com destaque para o a América Latina com $26,28 \%$ e o mercado norte americano, com aumento de $16,22 \%$. 
Quadro 4.41 Exportações brasileiras de Papel por destino (U milhões FOB)

\begin{tabular}{|c|c|c|c|c|c|}
\hline Tipo & $\mathbf{2 0 0 9}$ & $\mathbf{2 0 1 0}$ & $\mathbf{2 0 1 1}$ & $\mathbf{2 0 1 2}$ & $\mathbf{2 0 1 3}$ \\
\hline América Latina & 875 & 1.127 & 1.244 & 1.140 & 1.105 \\
\hline União Européia & 305 & 366 & 380 & 298 & 284 \\
\hline América do Norte & 228 & 203 & 207 & 196 & 265 \\
\hline África & 120 & 98 & 110 & 97 & 92 \\
\hline Ásia/Oceania & 117 & 128 & 150 & 143 & 142 \\
\hline China & 41 & 86 & 97 & 77 & 82 \\
\hline Total & $\mathbf{1 . 6 8 6}$ & $\mathbf{2 . 0 0 8}$ & $\mathbf{2 . 1 8 8}$ & $\mathbf{1 . 9 5 1}$ & $\mathbf{1 . 9 7 0}$ \\
\hline
\end{tabular}

Fonte: BRACELPA (www.bracelpa.org.br)

Com relação às empresas brasileiras produtoras de papel para imprimir e escrever e de acordo com informações contidas nos relatórios setorias da BRACELPA, por exemplo, a fábrica da Suzano registrou queda de $2,8 \%$ em suas vendas para o mercado europeu no período analisado enquanto que a fábrica de Luiz Antônio registrou aumento de $5 \%$.

De acordo com os dados contidos nos Quadros anteriores e levando-se em consideração informações dos representantes do grupo IPI:

- Do valor total em US\$, das exportações brasileiras de papel para imprimir e escrever, 20\% corresponde às exportações para a União Européia;

- Do total das exportações brasileiras de papel para imprimir e escrever, em quantidade, 22\%, em média, tem como destino a União Européia;

- No ano de 2011, a Fábrica de Luiz Antonio produziu 357.120 mil toneladas de papel para imprimir e escrever e exportou 142.848 toneladas. Desse total exportado, 20 \% (28.570 t) foram para a União Européia;

- A partir de 2012, com a obtenção do rótulo ambiental europeu e do fraco desempenho do setor de papel e celulose do continente europeu, a Fábrica de Luiz Antônio aumentou a participação das exportações para a União Européia em $5 \%$, em média, até 2014 . Dessa forma, 25\% do total exportado passou a ser direcionado para a União Européia;

- Em 2014, o Brasil exportou 975 mil toneladas de papel para imprimir e escrever que proporcionaram US\$301 milhões.

Da análise do Quadro 4.42, a seguir, e levando-se em conta as considerações feitas e os dados obtidos, verifica-se que a fábrica de Luiz Antonio, auferiu lucro nas vendas para a União Européia, de papel para imprimir e escrever rotulado. No período de 2012 a 2014, após a obtenção do rótulo ambiental europeu, a empresa aumentou em $5 \%$ suas vendas 
para aquele mercado e registrou lucro de US\$ 444 mil no ano de 2012, US\$ 256 mil em 2013 e US\$234 mil em 2014. O cálculo do lucro foi feito em relação ao ano de 2011.

Quadro 4.42 Cálculo do resultado econômico das exportações de papel para imprimir e escrever da Fábrica de Luiz Antonio - SP

\begin{tabular}{|l|c|c|c|c|}
\hline & $\mathbf{2 0 1 1}$ & $\mathbf{2 0 1 2}$ & $\mathbf{2 0 1 3}$ & $\mathbf{2 0 1 4}$ \\
\hline $\begin{array}{l}\text { Quantidade de papel para imprimir e escrever exportada pelo } \\
\text { Brasil (mil toneladas) }\end{array}$ & 1.034 & 952 & 920 & 975 \\
\hline $\begin{array}{l}\text { Quantidade de papel para imprimir e escrever exportada pelo } \\
\text { Brasil para a União Européia (mil toneladas) }\end{array}$ & 227 & 209 & 202 & 214 \\
\hline $\begin{array}{l}\text { Valor Total exportado pelo Brasil para a União Européia } \\
\text { (US\$ milhões) }\end{array}$ & 76 & 59,60 & 56,80 & 60,2 \\
\hline Preço/tonelada (US\$/ton) & 334,80 & 285,16 & 281,18 & 281,30 \\
\hline $\begin{array}{l}\text { Produção de papel para imprimir e escrever da Fábrica de } \\
\text { Luiz Antônio (toneladas) }\end{array}$ & 357.120 & 351.000 & 349.280 & 348.370 \\
\hline $\begin{array}{l}\text { Quantidade de papel para imprimir e escrever exportado pela } \\
\text { Fábrica de Luiz Antonio (toneladas) }\end{array}$ & 142.848 & 140.400 & 139.712 & 139.348 \\
\hline $\begin{array}{l}\text { Quantidade de papel rotulado exportado para a União } \\
\text { Européia pela Fábrica de Luiz Antonio (mil toneladas) }\end{array}$ & 28.570 & 35.100 & 34.928 & 34.837 \\
\hline Valor em US\$ milhões & 9.565 & 10.009 & 9.821 & 9.799 \\
\hline $\begin{array}{l}\text { Lucro em função do aumento das exportações (US\$ mil), em } \\
\text { relação ao ano de 2011. }\end{array}$ & - & $\mathbf{4 4 4}$ & $\mathbf{2 5 6}$ & $\mathbf{2 3 4}$ \\
\hline
\end{tabular}

Fonte: Elaboração própria

Comparativamente, e de acordo com dados contidos nos relatórios setoriais da BRACELPA, no mesmo período, a fábrica de Suzano do grupo Suzano Papel e Celulose, registrou diminuição de 2,8 \% nas quantidades exportadas para a União Européia. Os dados analisados não permitem concluir que a redução das vendas da fábrica de Suzano está relacionada com o fato de a empresa não possuir o rótulo ambiental europeu, mas pode-se afirmar que o aumento das vendas da Fábrica de Luiz Antonio para a União Européia estão relacionadas com a obtenção do rótulo ambiental europeu.

Adicionalmente ao aumento das vendas para a União Européia, a Fábrica de Luiz Antônio apresentou bom desempenho ambiental após a aquisição do rótulo ambiental europeu. Podem-se comprovar dessa forma a premissa básica da ME que assegura benefícios econômicos e bnefícios ambientais para as empresas que a adotam.

A seguir são feitas algumas considerações e comparações adicionais sobre os benefícios advindos da adoção da rotulagem ambiental e da ME pela fábrica de Luiz Antônio. Leva-se em consideração alguns dos itens utilizados como critérios pelo Programa 
de Rotulagem Ambiental da União Européia e pelo Programa de Qualidade Ambiental da ABNT.

\section{I - Consumo de energia}

Do Quadro 4.24 verifica-se que a Fábrica de Luiz Antônio registrou em 2012 a média de consumo de 4,71 Gj / tonelada de papel rotulado produzido e em 2013 a média de 4,59 $\mathrm{Gj} /$ tonelada de papel rotulado produzido.

Levando-se em consideração que a quantidade de papel rotulado e exportado para a União Européia no ano de 2012 foi de 35.100 toneladas e no ano de 2013 foi de 34.928 conclui-se que o consumo de energia foi de 165.321 GJ e 160.319 GJ, respectivamente. Este valor representa uma economia no consumo de energia de 5.002GJ no período.

Por outro lado, e de acordo com o Quadro 4.28, a fábrica de Suzano, do grupo Suzano Papel e Celulose, cujo papel não é rotulado, registrou média de consumo de energia, em 2012 de 31,93 GJ/tonelada de papel produzido.

Levando-se em consideração a mesma quantidade de papel produzido pela fábrica de Luiz Antônio em 2012, de 35.100 toneladas, chega-se ao valor de um consumo de energia de 1.120.743 GJ. Conclui-se que a fábrica de Suzano consumiu 955.422GJ, em 2012, mais que a fábrica de Luiz Antônio para produzir a mesma quantidade de papel.

Fica evidente, dessa forma, que a rotulagem ambiental contribui efetivamente para a redução do consumo de energia nos processos produtivos e os torna mais eficientes.

\section{II- Àgua captada}

Do Quadro 4.29 verifica-se que em 2012 a fábrica de Luiz Antônio registrou média de captação de 66,94 $\mathrm{m}^{3}$ de água por tonelada de papel produzido. Se essa quantidade captada fosse utilizada somente para a produção do papel para cópia e impressão e levando-se em consideração a quantidade de 35.100 toneladas de papel rotulado exportado para a União Européia nesse ano, conclui-se que foram captados $2.349 .594 \mathrm{~m}^{3}$ de àgua.

Comparando-se a quantidade de água captada pela Fábrica de Limeira, do grupo Suzano Papel e celulose, conforme Quadro 4.30, verifica-se que a referida empresa apresentou média de $87,65 \mathrm{~m}^{3}$ de àgua captada por tonelada de papel produzido. Levando em conta as mesmas considerações anteriores e a mesma quantidade de papel produzido de 35.100 toneladas verifica-se a captação de $3.076 .515 \mathrm{~m}^{3}$.

Conclui-se que a fábrica de limeira captou $726.921 \mathrm{~m}^{3}$ de àgua a mais para produzir a mesma quantidade de papel que a fábrica de Luiz Antônio. 


\section{III - Emissões totais de gases de efeito estufa}

Do Quadro 4.32 verifica-se que a Fábrica de Luiz Antonio apresentou média de emissões de gases de efeito estufa de $0,172 \mathrm{t} \mathrm{CO}_{2 \text { eq }}$ por tonelada de papel produzido em 2011, enquanto que em 2012 a média apresentada foi de $0,155 \mathrm{tCO}_{2 \text { eq. Levando-se em }}$ consideração a quantidade de 28.570 toneladas de papel produzidas e exportadas para a

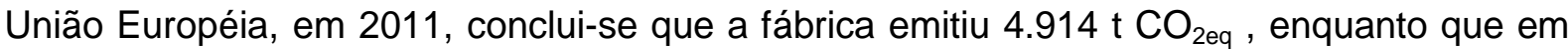
2012, e para produzir a mesma quantidade de papel rotulado, a fábrica emitiria $3.299 \mathrm{t}$ $\mathrm{CO}_{2 \text { eq, }}$, o que representaria uma redução nas emissões de gases de efeito estufa de $1.615 \mathrm{t}$ $\mathrm{CO}_{\text {2eq. }}$.

Dessa forma, pode-se concluir que a aquisição do rótulo ambiental pela fábrica de Luiz Antônio do grupo IP possibilitou que a empressa auferisse resultados positivos com as vendas para a União Européia e apresentasse bons resultados quanto ao desempenho ambiental. Considerando que a rotulagem ambiental é um instrumento da ME conclui-se que a adoção da ME pela fábrica de Luiz Antonio possibilitou que a mesma pudesse auferir benefícios econômicos simultaneamente com benefícios ambientais. 


\section{CONCLUSÃO}

O objetivo geral desta pesquisa foi responder quatro questões formuladas com o intuito de contribuir para a aplicação da ME no setor de papel e celulose do Brasil, utilizando a rotulagem ambiental como um de seus instrumentos.

As perguntas foram:

- A ME contribui para explicar e compreender as mudanças necessárias nos padrões vigentes de produção e de consumo para padrões mais sustentáveis com o objetivo de superar a crise ambiental?

- A aplicação dos pressupostos da ME pelas empresas favorece a mudança de padrão de produção?

- A Rotulagem Ambiental pode ser considerada um instrumento de mercado de promoção da ME?

- A Rotulagem Ambiental agrega competitividade aos produtos nacionais em mercados globais, incentiva a inovação ambiental e melhora o desempenho ambiental de processos produtivos?

Para a consecução desses objetivos foi elaborado um estudo de caso com a fábrica de Luiz Antônio, uma empresa do setor de papel e celulose nacional, pertencente ao grupo IP, que se submeteu à avaliação do Programa de Rotulagem Ambiental da União Européia (Flower) para a obtenção deste rótulo para um de seus produtos: o papel para cópia e impressão.

O desenvolvimento do referido estudo de caso permitiu que fossem alcançados os objetivos específicos deste trabalho, como a avaliação dos principais pressupostos da ME; a análise dos conceitos, dos objetivos e do funcionamento da rotulagem ambiental, assim como das características principais dos Programas de Rotulagem Ambiental da União Européia e do Brasil.

Adicionalmente foi elaborado um panorama do setor de papel e celulose no Brasil que permitiu conhecer suas especificidades e características para poder entender os desafios ambientais existentes no setor.

Levando-se em consideração os limites existentes nessa pesquisa, as aproximações utilizadas, e as relatividades dos dados encontrados, considera-se que os objetivos propostos foram alcançados. No que se refere à primeira pergunta da Tese e as informações disponibilizadas nos capítulos 1 e 2 desta pesquisa, conclui-se que a ME explica e facilita o entendimento de que o alcance da sustentabilidade e da superação da crise ambiental, notadamente pela indústria, necessariamente passa por uma mudança nos padrões de produção e de consumo vigentes. 
A superação da crise ambiental proposta pela ME não inclue mudanças radicais no sistema de produção capitalista, mas propõe ajustes nos processos produtivos e de consumo para que produtores e consumidores participem efetivamente do "esverdeamento da economia". Os produtores poderão oferecer produtos com impactos ambientais cada vez menores e os consumidores poderão comprar, cada vez mais, esses produtos.

Os processos produtivos são modificados e continuamente melhorados com a inovação tecnológica ambiental que os torna mais eficientes e menos intensivos em recursos naturais e, portanto menos poluidores para que os consumidores, mais conscientes sobre a questão ambiental possam viabilizar o desenvolvimento de um mercado para os produtos "verdes".

Chegou-se a conclusão que no contexto da ME o desenho, o desempenho e a avaliação dos processos de produção estão baseados em critérios ecológicos, além dos clássicos critérios econômicos. Dessa forma, a aplicação da ME prioriza o uso de critérios ecológicos como indicador do desempenho ambiental das empresas que tem um papel relevante no processo de reestruturação ecológica na indústria.

Cabe ressaltar que apesar dos benefícios que são promovidos pela ME, torna-se necessário levar em consideração que a simples transposição de metodologias e conceitos da União Européia para o contexto do Brasil tende a apresentar limitações e problemas. Capítulo I desta tese mostrou que o contexto que deu origem à ME é distinto daquele localizado no Brasil.

A ME, de forma geral, não se aplica à realidade do Brasil, que possui deficiências específicas nas dimensões social, ambiental e econômica e por isso, necessita de uma adapatação dos preceitos da ME ao nosso contexto. No entanto, alguns setores da economia nacional, notadamente os setores exportadores, em função da exigência da adequação de seus produtos às normas ambientais e aos consumidores conscientes dos mercados internacionais, demonstram interesse na observação desses preceitos e apresentam resultados efetivos de ME.

O setor de papel e celulose foi um dos primeiros setores da economia global a aplicar os preceitos da ME. Ainda no início da década de 1980 e em função do desempenho insatisfatório das tecnologias de fim de tubo no controle da poluição e do déficit de implementação de regulamentação advindos da década de 1970, o setor iniciou o processo de modernização de seus processos produtivos que eram associados aos impactos ambientais negativos.

Foi o caso, por exemplo, do banimento do uso do cloro no processo de branqueamento da celulose para a produção do papel e que foi substitúido pelo uso de compostos não tóxicos para a saúde humana e para o meio ambiente, além da inovação 
ambiental representada pelo uso do licor negro, que era considerado um resíduo e passou a ser utilizado como combustível para a geração de energia.

Tais substituições tiveram início primeiramente nas fábricas do setor de papel e celulose dos países nórdicos, que são grandes produtores mundiais de celulose e de papel e que foram um dos precursores da aplicação da ME. Responderam à pressão dos consumidores e dos governos de seus países desenvolvendo inovação tecnológica ambientalmente eficiente.

Levando-se em consideração os resultados do estudo de caso elaborado nesta pesquisa conclui-se que a fábrica de Luiz Antônio alterou partes do processo produtivo, substituiu substâncias químicas, reduziu o consumo de combustíveis fósseis e aumentou o consumo de recursos renováveis utilizados nestes processos, na medida em que a aplicação da ME por meio da rotulagem ambiental exigiu que critérios mais sustentáveis fossem respeitados pela empresa.

Estas medidas comprovam que os padrões de produção são modificados pela adoção da ME, o que responde a segunda pergunta desta Tese. Sugere-se, no entanto, que estudos posteriores considerem os consumidores para que seja avaliada a influência da ME, por meio da rotulagem ambiental, na mudança dos padrões de consumo vigentes para padrões mais sustentáveis.

Os resultados do estudo de caso mostraram que o desempenho ambiental da fábrica de Luiz Antônio, após a obtenção do Flower e do colibri, melhorou sensivelmente, principalmente no que diz respeito aos indicadores relacionados com as emissões de gases de efeito estufa e com o consumo de energia. Além disso, a empresa apresentou resultado financeiro positivo com as vendas do papel rotulado para o mercado Europeu.

A adoção da rotulagem ambiental permitiu que a fábrica de Luiz Antônio tivesse benefícios ambientais e benefícios econômicos simultaneamente, mostrando que é possível harmonizar a proteção ambiental com o crescimento econômico, fato que mostra uma relação direta da rotulagem ambiental com um dos pressupostos principais da ME.

Dessa forma, pode-se responder a terceira pergunta desta Tese e confirmar que a rotulagem ambiental é um instrumento de mercado que promove a ME na medida em que, dentre outras características, viabiliza o desenvolvimento econômico com a proteção ambiental e incentiva a inovação tecnológica ambiental.

Os processos de obtenção do rótulo ambiental europeu e brasileiro mostraram que a reestruturação ecológica das empresas está se desenvolvendo num contexto de maior interdependência gerada pelos processos de globalização em curso, especialmente na sua dimensão econômica e não fica confinada apenas no inteiror das fronteiras de um único país, nem somente no âmbito dos países desenvolvidos. 
A empresa brasileira foi também motivada para participar do Projeto de Cooperação e obter o rótulo ambiental europeu para poder competir efetivamente no mercado externo com reais chances de ganhar mercado e aumentar as suas vendas. Para isso se submeteu às regras de reestruturação ecológica da União Européia, por meio da rotulagem ambiental. O processo de globalização exige que as empresas se modernizem por meio da inovação tecnológica ambiental.

O estudo de caso elaborado demonstrou que a empresa brasileira conseguiu aumentar as suas vendas e ganhar mercado europeu com a abtenção do Flower. Esses foram alguns dos ganhos mensuráveis que foram percebidos nesta Tese, mas ressalta-se que existem ganhos que não são mensuráveis, mas que contribuem para que a competitividade dos produtos aumente.

É o caso, por exemplo, do valor positivo que é acrescido à imagem da empresa e dos seus produtos em função da aquisição do rótulo ambiental que comprova que os processos produtivos utilizados contribuem para a sustentabilidade do planeta.

Nos países onde os consumidores são mais conscientizados com as questões ambientais, tal mensuração torna-se mais simples. Na União Européia isso é mais perceptível e provavelmente contribuiu para que o produto da fábrica de Luiz Antônio, do grupo IP, apresentasse aumento nas vendas naquele continente, contribuindo dessa forma para o aumento de sua competitividade.

A rotulagem ambiental, além de melhorar a competitividade de produtos nacionais em mercados globais, incentiva a inovação tecnológica ambiental na medida em que é necessário constante aprimoramento do desempenho ambiental da empresa para que a mesma possa manter o rótulo ambiental adquirido, pois os critérios ambientais desses programas de rotulagem ambiental são regularmente alterados para valores mais rigorosos e para alcançá-los as empresas precisam melhorar continuamente seus processos produtivos.

Para isso torna-se necessária a inovação tecnológica ambiental. Exemplo no estudo de caso foi a substituição de uma caldeira movida a combustível fóssil por uma caldeira movida à biomassa, pela fábrica de Mogi Guaçu, do grupo IP, para que possa atingir os índices de emissões de gases de efeito estufa e de consumo de energia que são exigidos pelo Programa de Rotulagem Ambiental Europeu para a obtenção do Flower.

Estes fatos mostram que a quarta pergunta da Tese também foi respondida, pois se conclui da análise dos resultados do estudo de caso que a rotulagem ambiental efetivamente agrega competitividade aos produtos nacionais em mercados globais, incentiva a inovação tecnológica ambiental e melhora o desempenho ambiental dos processos produtivos. 
Apesar da efetividade da rotulagem ambiental como instrumento de promoção da ME é importante ressaltar que possui inúmeras limitações e que o fato de a empresa analisada pertencer a um grande grupo privado global, facilitou a constatação de resultados positivos neste trabalho.

O lucro obtido pela fábrica de Luiz Antônio nas vendas com a União Européia compensou as despesas ocorridas durante a preparação para o processo de obtenção do rótulo ambiental e as despesas para a manutenção desse rótulo. O mesmo poderia não ocorrer se o processo fosse desenvolvido por uma pequena ou micro empresa.

Outras limitações que devem ser consideradas é o fato do rótulo ser apenas um símbolo e não informar os consumidores sobre os aspectos ambientais dos produtos e a possibilidade de a rotulagem ambiental se transformar em uma barreira comercial já que as dificuldades econômicas globais impõem aos países uma postura cada vez mais protecionaista em relação aos seus mercados nacionais.

Torna-se importante dessa forma, a continuação de pesquisas sobre a aplicação da ME por meio da rotulagem ambiental em outros setores da economia, com outros atores privados, governamentais e da sociedade em geral, principalmente no Brasil, para que possa ser avaliada a eficiência da rotulagem ambiental como instrumento da ME na procura de alternativas para a solução da crise ambiental.

As pesquisas com a aplicação da ME nos processos produtivos são muito importantes para que se possa alcançar mudanças eficientes nos padrões de produção e esse enfoque tem se sobressaído significativamente nas pesquisas tanto no Brasil quanto em outros países. É preciso, então incentivar pesquisas que considerem o comportamento do consumidor frente aos produtos rotulados para que se possa conhecer a capacidade da ME e da rotulagem ambiental de alterar padrões de consumo.

Importante destacar como sugestão, o uso dos critérios ambientais dos Programas de Rotulagem Ambiental para impulsionar o desenvolvimento das compras públicas sustentáveis no Brasil. Alguns desses critérios poderiam ser usados, ou até mesmo reformulados para que possam constar dos editais de licitação pública para identificar produtos mais sustentáveis que possam ser comprados pelos órgãos públicos.

É uma forma de os Governos apoiarem politicamente as empresas que investem na rotulagem ambiental e na sustentabilidade de seus processos produtivos e ajudar a desenvolver um mercado para os produtos rotulados já que ainda o Brasil não possui demanda para isso, em função da baixa conscientização dos consumidores brasileiros e dos preços desses produtos "verdes" que geralmente são mais caros que os produtos concorrentes não rotulados.

O papel para cópia e impressão que foi estudado nesta Tese é um bom candidato para iniciar o processo de compras públicas sustentáveis no Brasil, já que é um produto 
bastante utilizado pelos órgãos públicos brasileiros e possui critérios ambientais já definidos pela Associação Brasileira de Normas Técnicas (ABNT), detentora do rótulo ambiental Colibri. Sugere-se, porém, que esses critérios ambientais sejam reformulados para que fiquem adequados aos produtores de papel nacionais e tanto as grandes empresas quanto as pequenas e médias possam participar das licitações.

O uso da rotulagem ambiental no processo de compras públicas sustentáveis no Brasil representa uma oportunidade de o Estado brasileiro agir como um consumidor conscientizado da necessidade urgente da ME dos padrões de produção e de consumo no Brasil. 


\section{REFERÊNCIAS BIBLIOGRÁFICAS}

ADAMS,W.M. Green development: environment ans sustainability in the third world. Routledge: London, 1990.

ANON. The World Conservation Strategy: Living resource conservation for sustainable development. MCN/UNEP/WWF, Geneva, 1980.

BARBOZA, E.M.F. Rótulos ambientais e análise do ciclo de vida (ACV). Brasília: IBICT, nov.2001.

BARHAM, E. What's in a Name? Eco-labelling in the global food system. Cornell University, 1977. Available on line: www.pmac.net

BAUDRILLARD, J. The consumer society: myths and structures. London: Sage Publications, 1998.

BECK, U. A reinvenção da política: rumo a uma teoria da modernização reflexiva. IN: GIDDENS, Anthony; BECK, Ulrich; LASH, Scott. Modernização Reflexiva. Política, tradição e estética na ordem social moderna. São Paulo: UNESP, 1997.

BECK, U. Sociedade de risco: rumo a uma outra modernidade. São PAULO. Editora $34,2010$.

BLEDA, M; VALENTE, M. Graded eco-labels: a demand-oriented approach to reduce pollution. Technological Forecasting \& Social Change, Amsterdam, Elsevier, v.76, número único, p. 512-524, 2009.

BLOWERS, Andrew. Environmental policy ecological modernization or risk society? IN Urban Studies, Vol 34, Nos 5-6, pp. 845-871, 1997.

BOGSTROM, M; KLINTMANN, M. Eco-Standards, product labelling and green consumerism. London: Palgrave, 2008.

BRAGA, A.S; MIRANDA, L.C. (Org.) Comércio e meio ambiente: uma agenda para a américa latina e caribe. Brasília: MMA/SDS, 2002. 
BRASIL. Ministério do Meio Ambiente (MMA). Rotulagem ambiental: documento base para o programa brasileiro derotulagem ambiental. Brasília: MMA/SPDS, 20p. 2002

BRASIL. Ministério do Meio Ambiente (MMA). Plano de ação para a produção e consumo sustentável. Brasília, 2008.

BURSZTYN, M; PERSEGONA, M. A grande transformação ambiental. Uma cronologia da dialética homem-natureza. Garamond Universitária, 2008.

BUTTEL, Frederick. Ecological modernization as social theory. GeoForum 3, 2000. (pp.: 57-65).

BUTTEL, Frederick. New directions in environmental sociology. In: Annual review of sociology, 23: 1987, pp.337-356.

CHEN, Y; LAI, S. WEN, C.The influence of green innovation performance on corporate advantage in Taiwan. Journal of Business Ethics, v. 67, n.4, p. 331-339. 2006.

CLIATH, A.C. Seeing shades: ecological and socially just labelling. Organization environment, 20 (4). (pp. 413-439), 2007.

CHRISTOFF, P. Ecological modernization, ecological modernities. IN: The Ecological Modernization Reader - Environmental Reform in Theory and Practice. MOL, A.P.J; SONNENFELD, D.A; SPAARGAREN, G. (Eds.), Routledge. London and New York, 2010.

COHEN, M. Ecological modernization and its discontents: The American environmental movement's resistance to an innovation-driven future. IN: Futures, Vol. 38, Issues 5, 2006. (pp. 528-547).

CORREA, L.B.C.G. Comércio e meio ambiente: atuação diplomática brasileira em relação ao selo verde. Brasília: Instituto Rio Branco; Fundação Alexandre de Gusmão; Centro de Estudos Estratégicos, 1998.

COUTINHO, L.G. et al. Estudo da competitividade de cadeias integradas no Brasil: impactos das zonas de livre comércio, cadeia de papel e celulose. Campinas, SP: UNICAMP, 2003. 
DEERE, C.L. Eco-labelling and sustainable fisheries, IUCN: Washington, D.C. and FAO: Rome, 1999.

DIAS, G. M. M. Qual o critério da rotulagem ambiental? Revista em agronegócios e meio ambiente, v.1, n.2, p. 279-289, maio/agosto. 2008.

DOUGLAS, M; ISHERWOOD, B. The world of goods towards anthropology of consumption. Routledge, London \& New York, 1979.

DOWING, P. B; HANF, K. (Eds). International comparisons in implementing pollution laws. The Hague: Kluwernijhoff, 1983.

EKINS, P. A new world-order - grassroots movements for global change. Routledge, London. 1992.

ELETROBRAS. Programa Nacional de Conservação dde Energia Elétrica - Procel. Disponível em: http://www.eletrobras.com/elb/procel/main.asp

ELKINGTON, J; HAILES, J; MAKOWER, J. The green consumer, London: Penguin, 1990

ERSKINE, C; COLLINS, L. Eco-labelling: success or failure? The Environmentalist, Chicago, v.17, número único, p. 125-133, 1997.

EU- ECOLABEL (FLOWER) - User's manual for the application for copying and graphic paper. Version 2002. Available at:

www.ec.europa.eu/environment/ecolabel/documents/usermanual paper.pdf

EUROBAROMETER: Europeans' attitudes towards the issue of sustainable consumption and production. Analytical Report, Flash Eurobarometer 256 - The Gallup Organization, 2009. Available at: http:// ec.europa.eu/public_opinion/flash/fl_256_en.pdf

EUROPEAN COMISSION: Communication from the Commission to the European Parliament, the Council, The European Economic and Social Committee and the Committee of the Regions on the Sustainable Consumption and Production and Sustainable Industrial Policy Action Plan, SEC (2008), COM/2008/0397, 2008. Available at:

http://eurlex.europa.eu/LexUriServ/LexUriServ.do?uri=COM:2008:0397:FIN:EN:HTML 
EUROPEAN COMISSION: EU Ecolabel Work Plan for 2011-2015, 2011. Available at: http://ec.europa.eu/environment/ecolabel/about ecolabel/pdf/work plan.pdf

EUROPEAN COMISSION: EUROPE 2020. A strategy for smarte, sustainable and inclusive growth, COM (2010) 2020 Final, 2012. Available at:

http://eurlex.europa.eu/LexUriServ/LexUriServ.do?uri=COM:2010:2020:FIN:EN:PDF

FAVERIN, V. Rotulagem ambiental certifica menor impacto e conscientiza consumidores. Revista Meio Ambiente Industrial, São Paulo, 25 dez. 2009.

FEATHERSTONE, M. Consumer culture and postmodernism. London: Sage, 1991.

FISHER, D. and FREUDENBURG, W. Ecological modernization and its critics: assessing the past and looking toward the future: IN: Society and natural resources, 14, 2001. (pp. 701-709).

FOODWATCH; Organic: a climate savior? The foodwatch report on the greenhouse effect of conventional and organic farming in Germany based on the study: The Impact of German Agriculture on the Climate by the Institute for Ecological Economy Research (IOW0, KLEF Karl Linder Education Foundation. 2008. Available at: http://foodwatch.de/foodwatch/content/e6380/e24459/e24474/foodwatch report on the greenhouse effect of farming 052009 ger.pdf

FULPONI, L. The globalization of private standards and the agri-food system. IN: SWINNEN, J.F.M. (Ed.). Global Supply Chains Standards and the Poor. (pp. 5-18), London, UK: CAB International, 2007.

GALLASTEGUI, I. G. On the economics of Ecolabelling: a case study for fair trade coffee in the U.K. PhD Thesis. Department of Economics and International Development. University of Bath. 2001.

GEELS, F. Technological transitions and system innovation: a co-evolutionary and socio-technical analysis. Cheltenham: Edward Elgar, 2005b.

GLOBAL ECOLABELLING NETWORK (GEN). The Ecolabelling guide: a guide to Ecolabelling around the world, October, 1999. 
GLOBAL ECOLABELLING NETWORK (GEN). Information Paper: introduction to Ecolabelling, July 2004.

GIBBS, D. Ecological modernisation, regional economic developmente and regional development agencies. Geoforum 31, 9-19. (2000).

GIDDENS, A. A constituição da sociedade. São Paulo: UNESP, 1991a.

GIDDENS, A. As consequências da modernidade. São Paulo: UNESP, 1991b

GRANKVIST, G. Determinants of choice of eco-labelled products. Dissertation. Department of Psychology, Goteborg University, Sweden, 2002.

GROTE, U. Eco-labelling in agriculture, high-level pan-european conference on agriculture and biodiversity: towards integrating biological and landscape diversity for sustainable agriculture in europe. Strasbourg, March 4, 2002.

GUERRA, J.L. Labells that tell stories. Ecolabelling Public Symposium at WTO "Challenges ahead on the Road to Cancun", June 18-19, 2003.

HAJER, M.A. The politics of environmental discourse ecological modernization and the policy process, Oxford: Oxford University Press. 1995.

HAJER, M.A. Ecological modernization as cultural politics. IN: The Ecological Modernization Reader - Environmental Reform in Theory and Practice. MOL, A.P.J; SONNENFELD, D.A; SPAARGAREN, G. (Eds.), Routledge. London and New York, 2010.

HARVEY, D. Justice, nature and geography of difference. Blackwell Publishers. (parte II, P. 117-204 e parte II, p. 366-400), 1996.

HELD, D. Democracy, the nation-state and the Global System. IN: HELD, D. Political Theory Today. Cambridge: Polity Press, p. 201, 1991.

HESLOP, L.A. If we label it, will they care? The effect of GM-ingredient labelling on consumer responses. Journal of Consum Policy, New York, Springer US, v. 29, n.2, p. 203230, 2004. 
HOBSON, K. Competing discourses of sustainable consumption: Does the rationalization of lifestyles 'make sense? , Environmental Politics, 11(2), pp. 95-120, 2010.

HUBER, J. La inocência perdida de la ecologia. Las nuevas tecnologias el desarollo superindustrial. Buenos Aires: editora Abril, 1986.

HUBER, J. Towards industrial ecology: sustainable development as a concept of ecological modernization. Journal of Environmental Policy \& Planning, London, v.2, p. 269285, 2000.

HUBER, J. Environmental policy shift through technological innovation. IN: JACOB, K; BINDER, M; WIECZOREK, A. (Eds). Governance for industrial transformation. Proceedings of the 2003 Berlin Conference on the Human Dimensions of Global Environmental Change. Environmental Policy Research Centre. Berlin. (pp. 438 - 447), 2004.

HUBER, J. Ecological modernization: beyond scarcity and bureaucracy. IN: The Ecological Modernization Reader - Environmental Reform in Theory and Practice. MOL, A.P.J; SONNENFELD, D.A; SPAARGAREN, G. (Eds.), Routledge. London and New York, 2010.

HUSSAIN, S. S. The greening of industry: an ecological economic appraisal of ecoinnovation and Ecolabelling. PhD Thesis. The University of Edinburgh. 2009.

IPEA. Instituto de Pesquisa Econômica Aplicada. O Uso do poder de compra para a melhoria do meio ambiente. Série Eixos do Desenvolvimento Brasileiro. Comunicados do IPEA. $N^{*}$ 82. Sustentabilidade Ambiental no Brasil: biodiversidade, economia e bem-estar humano. 2011.

IFOAM. International Federation of Organic Agriculture Movements. Draft regulation on a community scheme COM (2008) 40/13, Brussels, 16 October 2008. Available at: http://

www.ifoam.org/about ifoam/around world/eu groupnew/positions/Papers/pdf/letter IFOAM EU COM ecolabelling 27.09.2011 Commissioners Ciolos and Potocnik.pdf 
IUCN. The future of sustainability. Re-thinking environment and development in the twenty-first century. 1997.

http://www.iucn.org/members/future sustainability/docs/iucn future of sustainability.pdf.

JACKSON, T. Challenges for sustainable sonsumption policy. IN: JACKSON, T. (Ed.). The Earthscan Reader in Sustainable Consumption. London: Earthscan, pp.109-129, 1996.

JÄNICKE, M. State failure. The impotence of politics in industrial society. Pennsylvania: Pennsylvania State University Press, 1990.

JÄNICKE, M. On ecological and political modernization IN: The Ecological Modernization Reader - Environmental Reform in Theory and Practice. MOL, A.P.J; SONNENFELD, D.A; SPAARGAREN, G. (Eds.), Routledge. London and New York, 2010.

JULIANI, A. Papel do governo no fortalecimento da rotulagem ambiental. Curso de capacitação sobre rotulagem ambiental. Ministério do Desenvolvimento, Indústria e Comércio Exterior (MDIC). Brasília, 11 mar. 2010.

KNEESE, A.V; SCHULZE, W.D. Ethics and Environmental economics. Resources for the Future, 1985.

KITSCHELT, H. Political opportunity structures and political protest: anti-nuclear movements in four democracies. British Journal of Political Science, 14:1.(pp. 57-85), 1986.

KLEIN, N. On logo. Flamingo, Great Britain, 2001.

KNOEPFEL, P; WEIDNER, $\mathrm{H}$. Explaining diferences in the performances of clean air policies: an International and inter-regional comparative study. Policy and Politics, 14/1. (pp.71-91), 1986.

LADVOCAT, G. Programa de qualidade ambiental da ABNT - Colibri. Curso de capacitação sobre rotulagem ambiental. Ministério do Desenvolvimento, Indústria e Comércio Exterior (MDIC). Brasília, 11 mar. 2010

$\mathrm{LI}, \mathrm{X} ; \mathrm{HERSH}, \mathrm{J}$. Understanding capitalism: crises and passive revolutions. Competition \& change 6 (2). (pp. 193-212), 2002. 
LUNDQVIST, L. The hare and the tortoise. Clean Air Policies in the United States and Sweden. Ann Arbor: University of Michigan Press, 1980.

MARX, K. Economic and philosophical manuscripts. IN: COLETTI, L.(Ed.) Karl MarX : Early Writings. Harmondsworth: Penguin, First Edition, 1844. 1974.

MICKELETTI, M. Political virtue and shopping: individuals, consumerism and collective action. London: Palgrave, 2003.

MILANEZ, B. Friend or foe? Ecological modernization in Brazil. Thesis submitted in partial fulfillment of the requirements for the Degree of Philosophy Doctor at Lincoln University. Lincoln University, 2006.

MILANEZ, B. Modernização ecológica no Brasil: limites e perspectivas. Desenvolvimento e Meio Ambiente, Curitiba, v. 20, p. 77-89, jul./dez. 2009.

MILANEZ, B; BUHRS, T. Marrying strands of ecological modernization: a proposed framework. In: Environmental Politics, Vol. 16, N4, Pp 565-583. August, 2007.

MOL, A. P. J.The refinement of production. Ecological modernization theory and the chemical industry. Utrecht: International Books, 1995.

MOL, A. P. J. Ecological modernization and institutional reflexivity: environmental reform in the late modern age. Environmental Politics, Summer. V5, n2, pp. 302-322, 1996.

MOL, A. P. J. Globalization and environmental reform: the ecological modernization of the global economy. Cambridge, MA: MIT Press, 2001.

MOL, A.P.J; JANICKE, M. The origins and theoretical foundations of ecological modernization theory. IN: The Ecological Modernization Reader - Environmental Reform in Theory and Practice. MOL, A.P.J; SONNENFELD, D.A; SPAARGAREN, G. (Eds.), Routledge. London and New York, 2010.

MOL, A. P. J. and SPARGAAREN, G. Ecological modernization theory in debate: a review. Environmental Politics, 2000, 9: 1. 
$\mathrm{MOL}$, A. P. J. Environment in the information age: The transformative powers of environmental information. IN: Ciência, tecnologia e sociedade: novos modelos de governança. Brasília: CGEE/FAPESP/EMBRAPA/UFSC, 2005 a.

MOL, A. P. J; SPAARGAREN, G. Environment, modernity and the risk-society. The apocalyptic horizon of environmental reform. IN: International Sociology, Vol 8, N4, 1993. (pp. 431-459).

MOL, A. P. J; SPAARGAREN, G. Towards a sociology of environmental flows. A new agenda for twenry-first-century environmental sociology. IN: SPAARGAREN G; MOL, A.P.J;BUTTEL, F.H(Eds.). Governing Environmental Flows. Global Challenges for Social Theory. Cambridge, MA: MIT Press, pp. 39-83, 2006

MOVIMENTO MUNDIAL PELAS FLORESTAS TROPICAIS (MMFT). Certificando o não certificável: certificação pelo FSC de plantações de árvores na Tailândia e no Brasil, 2003. Disponível em: http://www.wrm.org.uy

MUNASINGHE, M. Can sustainable consumers and producers save the planet? Journal of Industrial Ecology. Vol 14, n-1. 2010.

MURPHY, J. From production to consumption: environmental policy in the european union. IN: COHEN, M.J; MURPHY, J. (Eds). Exploring Sustainable Consumption: Environmental Policy and the Social Sciences. (pp. 39-60), Oxford: Elsevier Science Ltd, 2011.

OECD - Organization for Economic Co-operation and Development. OECD/GD: Ecolabelling: actual effects of selected programmes. Paris, 1997.

OECD. Meeting of the environment policy committee at ministerial level, issues paper, pp. 120. 2004. Available at http://oecd.org/dataoecd/60/41/35407580.pdf

OLIVIERI, A.G. A teoria da modernização ecológica: uma avaliação crítica dos fundamentos teóricos. Tese de Doutorado apresentada ao Instituto de Ciências Sociais do Departamento de Sociologia da Universidade de Brasília (UNB), 2009.

OLSON, M.. A lógica da ação coletiva: os benefícios públicos e uma teoria dos grupos sociais. Editora da Universidade de São Paulo, São Paulo, 1999. 
ORSATO, R.J; CLEGG, S.R. Radical reformism: towards critical ecological modernization, sustainable development, 13. (pp. 253-267), 2005.

OOSTERVEER, P; GUIVANT, J; SPAARGAREN, G. Shopping for green food in globalizing supermarkets: sustainability at the consumption junction. IN: PRETTY, J;

PORTER, M; VAN DER LINDE, C. Green and competitive: ending the stalemate. Harvard Business Review 73, 5: 120-33, 1995.

PROGRAMA BRASILEIRO DDE CERTIFICAÇÃO FLORESTAL (CERFLOR). Certificação Florestal no âmbito do Sistema Brasileiro de Avaliação da Conformidade. Workshop internacional sobre rotulagem ambiental. Brasília, 4 dez. 2009.

PUJARI, D. Eco-innovation and new product development: understanding the influences on market performance. Tchnovation, v. 26, n.1, p. 76-85. 2006.

REDCLIFT, M. Sustainable development - exploring the contradictions. Methuen, London, 1987.

REDICLIFT, M; BENTON, T. (Eds.). Social theory and the global environment. London: Routledge, 1994.

RESOURCE EFFICIENCY ROADMAP: Communication from the Commission to the European Parliament, the Council, the European Economic and Social Committee, and the Committee of the Regions, Roadmap to a Resource Efficient Europe, Brussels, 20.9.2011, $\operatorname{COM}(2011) \quad 571 \quad$ Final, $2011 . \quad$ Available http://ec.europa.eu/environment/resource efficiency/pdf/com2011 571.pdf

ROSA, E.A. Modern Theories of Society and the Environment: The risk Society, 2000.

ROYON, M. I'emergence de systems nationaux de normalization -certification et leur connexion international. Revue international de Droit, Economique, n 3, 107-117. 1988.

RUBIK, F; SCHEER, D. Eco-labelling and product development: potentials and experiences. Institute for Ecological Economy Research (IÖW) gGmbH, Vol. 6, Nos.3/4, 2008. 
SCHNAIBERG, A. The environment: from surplus to scarcity. New York: Oxford University Press. 1980.

SCHOR JB. Prices and quantities: unsustainable consumption and the global economy. Ecological Economics. 2005, 55:309-20.

SCHUMACHER, E. F. O negócio é ser pequeno. Rio de Janeiro, Zahar. 1979.

SCHUMPETER, J. A. Capitalismo, socialismo e democracia. Rio de Janeiro: Zahar, 1984.

SCHUMPETER, J. A. A teoria do desenvolvimento econômico: uma investigação sobre lucros, capital, crédito, juro e o ciclo econômico. 2 ed. São Paulo: Nova Cultural, 1985.

SEIPPEL, O. Ecological modernization as a theoretical device: strengths and weaknesses. Journal of Environmental Policy and Planning 2, 4, pp. 287-302, 2000.

SEN, A. K. Desenvolvimento como liberdade. São Paulo. Companhia das Letras, 2000.

SETAC - Society of Environmental Toxicology and Chemistry. SETAC annual meeting, 23. North America: Achieving Global Environmental Quality. Integrating Science \& Management. Abstract Book, Utah, Nov. 2002.

SIMONIS, U. E. Ecological modernization of industrial society: three strategic elements. International Social Science Journal, Vol. 121, 336-347. 1989.

SONNENFELD, D.A. Contradictions of ecological modernisation: pupl and paper manufacturing in south-east asia. In: Ecological Modernisation around the World: Perspectives and critical debates, Eds MOL, A.P. e SONNENFELD, D.A. Portaland, ou, London, UK: Frank Cass, 2000.

SPAARGAREN, G. The ecological modernization of production and consumption. Essays in Environmental Sociology. PhD Thesis, Wageningen: Wageningen Agricultural University, 1997.

SPAARGAREN, G. Sustainable consumption: a theoretical and environmental policy perspective. IN: Society and Natural Resources, 16, pp. 687-701, 2003. 
SPAARGAREN, G. ( Eds.) Governing environmental flows. Global challenges to social theory. London: The MIT Press, 2006.

SPAARGAREN, G; COHEN, M. Greening lifecycles and lifestyles: sociotechnical innovations in consumption and production as core concerns of ecological modernization theory. IN: The Ecological Modernization Reader - Environmental Reform in Theory and Practice. MOL, A.P.J; SONNENFELD, D.A; SPAARGAREN, G. (Eds.), Routledge. London and New York, 2010.

SPATHELF, P. et al. Certificação florestal no Brasil: uma ferramenta eficaz para a conservação das florestas naturais? Floresta, Curitiba, v.34, n.3. p. 373-379, set./dez.2004.

TAYLOR, S. Making bureaucracies think. Stanford: Stanford University Press, 1984.

TUKKER, A. et al. Environmental impacts of products (EIPRO).Analysis of the life cycle environmental impacts related to the final consumption of the EU-25. Technical report series, EUR 22284 EN. IPTS; ESTO project. European comission. 2006

TUKKER, A; COHEN, M; HUBACEK, K; MONT; O. Impacts of household consumption and options for change. Journal of Industrial Ecology. Vol.14. N-1. 2010

UNCED. United Nations Conference on Environment and Development. Agenda 21. Chapter 8, 1992. Available at: http://www.un.org/documents/ga/conf151/aconf15126-1annex1.htm.

UNEP - International Expert Meeting Advertising and Sustainable Consumption. Paris, United Nations Environment Programme, Division of TECNOLOGY, Industrry and Economics, 21-22 January, 1999.

EPA -UNITED STATES ENVIRONMENTAL PROTECTION AGENCY: Environmental labeling, issues, policies and practices worldwide. Prepared for Pollution Prevention Division, Office of Pollution, Prevention and Toxics, EPA 742-R-98-009, December, 1998. Available at: www.epa.gov/opptintr/epp/pubs/envlab/cover.pdf

VEBLEN, T. The theory of the leisure class. New York: Macmillan, First edition, 1953. 
VEIGA, J. E. da. Mundo em transe: do aquecimento global ao ecodesenvolvimento. Campinas, SP.; Armazém do Ipê, 2009.

WCED -World Commission on Environment and Development. Our common future, Oxford: Oxford University Press, 1987.

WRI - The World Resources Institute, World Resources, 1990-1991. New York and Oxford: Oxford University Press. p.183, 1990.

WEALE, A. The new politics of pollution. Manchester and New York: Manchester University Press, 1992.

WEALE, A. Ecological modernization and the integration of European Environmental Policy. IN: LIEFFERINK, J.D; LOWE, P.D; MOL, A.P.J (Eds.). European Integration and environmental policy, London: Belhaven Press, pp. 196-216, 1993.

WEIDER, H. Clean air policy in Great Britain.- problem-shifiting as best practicable means. Berlin: Edition Sigma, 1987.

WELLS, C. Rotulagem ambiental. In: VILELA JÚNIORA, A; DEMAJOROVIC, J. (Org.). Modelos e ferramentas de gestão ambiental: desafios e perspectivas para as organizações. São Paulo: Editora SENAC, 2006. 396 p.

WILLIAMS, W. Eco-labelling: a socio-economic analysis. Doctoral Dissertation. Department of Sociology and Business Sociology. Department of Environmental Economics and Management. Vienna University of Economics and Business Administration, 2004.

WOLFF, P. SCHONHERR, N. The impact evaluation of sustainable consumption policy instruments. J Consum Policy, 34. (pp. 43-66), 2010.

WOODS, D; SCHNEIDER, R. Toxic Dude: the dell campaign. IN: SMITH, T; PELLOW, D. SONNENFELD, D. (Eds.). Challenging the Chip: Labor Rights and Environmental Justice in the Global Electronics Industry. Philadelphia: Temple University Press, pp. 285-297, 2006.

YORK, R. e E. A. Rosa. Key challenges to ecological modernization theory: institucional efficacy, case study evidence, units of analysis, and the pace of ecoefficiency. Organization \& environment, 13(3): 273-88 (2003). 
YOUNG, S. (ED.) The emergence of ecological modernization. Integrating the environment and the economy? London: ed. Routledge, 2000. 